
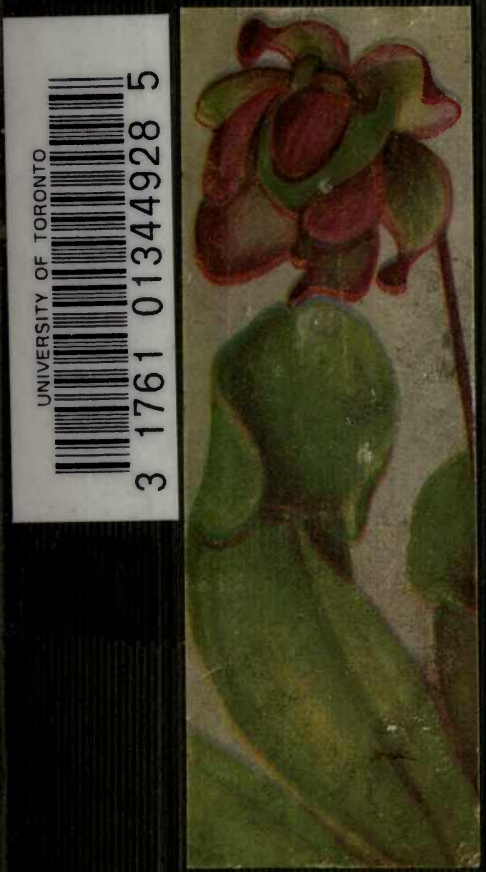

$$
\begin{gathered}
\text { EAST } \\
\text { OF } \\
\text { THE } \\
\text { ROCKIES }
\end{gathered}
$$



$\rightarrow$ or 






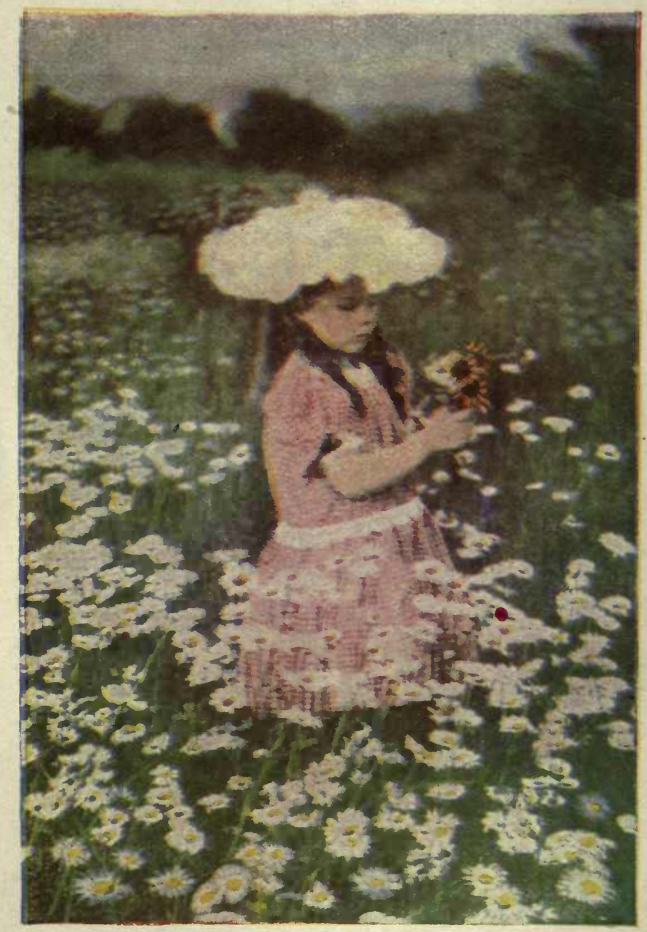

A Young Botanist 


\section{WILD FLOWERS}

\section{EAST OF THE ROCKIES}

\section{BY \\ CHESTER A. REED, B. S.}

Author of Land Birds, Water Birds, North American Birds, Etc.

With 320 Flowers in Color, painted by the Author

CHAS. K. REED

WORCESTER, MASS.

1910 


$$
\begin{aligned}
& \text { COPYRIGHTED } 191 \\
& \text { CHAt. K. REED } \\
& \text { WORCESTER, MASS. } \\
& \begin{array}{l}
\text { BF } \\
R \\
\frac{609830}{4.7 .55}
\end{array}
\end{aligned}
$$


TO

MERTICE ELAINE

The Little "Flower Girl" in the Frontispiece This Book is Affectionately Inscribed 



\section{PREFACE}

Every book has a reason for its being,-or should have. There are excellent flower books, galore, but apparently there is a break in the series into which it is hoped the present volume will make a welcome fit. We are living in a progressive age, an inquisitive age, an age in which we want to know the names and meaning of all we see and hear. I have always held that a well-executed colored picture, as a means of identification, is worth pages of text. Of course the text is necessary to call attention to the salient points of the picture. In the case of flowers, birds, mammals, etc., the habits, ranges, sizes and other important points must be obtained from the text, but the picture, itself, forms the basis of quick and sure identification.

I was practically brought up among birds and, consequently, flowers, because the two are inseparable companions in the fields. Wherever I wandered, I had one eye open for "new" flowers. Every such prize went home with me; if not carried in the hand, why, -in the top of the hat. No sooner home than out came the old "Gray's", the microscope and dissecting points. Sister and I eagerly weighed the evidence, placing the "find" in one family and then another, as discrepancies were found, until at last, we had it cornered down to the family, the genus and, finally, the exact species.

Every new invention is designed to accomplish some end quicker or better than it has been done before. 
viii

Every step aims to be a step in advance. The scientific botanist, a term correlary to that of "closet Naturalist" used in Ornithology, still does, and always will, analyze his flowers. The layman, however, has no interest in whether the seeds have copious albumen, or not, or in the number of cells in the plant ovary; he sees a flower,-it may be beautiful, it may be odd or even its very ugliness may attract his attention, but he wants to know what it is. To such seekers, and they include the majority of Nature lovers, scientific botany is as a foreign tongue, but the popular book with the colored pictures furnishes an open key to knowledge.

That is why this book appears:-We do not claim it to be perfect, for we know its shortcomings. But, in so far as it lies in our power, it has been made to serve the most people to their best advantage, taking into consideration the limitations set upon size and upon price.

Flowers vary endlessly in size, in color and shape. Some have simple stems, others are very branchy and bushlike in appearance. Obviously if we attempted to draw the whole of a branching plant, reducing it down to the size of a small page, the flowers would be so tiny they could barely be seen. In all cases it has been our object to show the flower and that part of the plant that will best serve to identify it. In nearly every case the typical form of flower and of leaf is shown.

To as great an extent as is practical, all technical terms have been avoided. In order, however, that one may if he wish learn the meanings of the botanical terms that are in very common use, a Glossary is provided. 
The opening pages touch briefly upon the subject of pollenization and propagation of plants. This is a study in itself and an exceedingly interesting one. There is still opportunity for a great deal of valuable research in this line of study; in fact, it is in the hope of awakening interest in this line that the many brief allusions in the text, to the methods of fertilization are made. The interdependence existing between the plant, the insect and the animal world is amazing. One will be astonished at the truths he will discover by closely watching the living plants and their visitors.

The body of the book contains plants, chiefly herbs, found east of the Rocky Mountains, that are conspicuous in flower. These are arranged in their natural and most approved order. Many attempts have been made to group flowers according to their colors, but there are so many colors and flowers of the same species vary so greatly that all such attempts have been chiefly failures as far as assisting easy identification is concerned.

About 90 per cent of the paintings, from which the colored illustrations were made, were sketched and colored directly from freshly collected flowers gathered from Maine to Virginia. I have been very greatly assisted in the work by many friends, and am especially indebted to Mrs. Ella L. Horr, Custodian at the Worcester Natural History Museum, and to Mr. Herbert D. Braman, Curator in the Dept. of Mineralogy, in the same Institution; very many of the flowers figured herein, especially some of the rarer varieties, were collected and kindly loaned by them.

The technical descriptions and ranges are based 
chiefly upon "Gray's Manual" and "Britton and Brown". The scientific names and order of classification are those adopted by the international Botanical Congress, the same as now incorporated in the new seventh edition of "Gray's."

Worcester, Mass.

CHESTER A. REED,

March, 1910. 


\section{TABLE OF CONTENTS}

Preface $\ldots \ldots \ldots \ldots \ldots \ldots \ldots \ldots \ldots \ldots \ldots \ldots \ldots$ VII

Glossary of Botanical Terms $\ldots \ldots \ldots \ldots \ldots \ldots$ XIII

Parts of Plants ................... 3

Methods of Reproduction $\ldots \ldots \ldots \ldots \ldots \ldots \ldots .9$

Specialized Flowers $\ldots \ldots \ldots \ldots \ldots \ldots \ldots \ldots \ldots 14$

WILD FLOWERS $\ldots \ldots \ldots \ldots \ldots \ldots \ldots \ldots \ldots .17$

Key to Flowers by Color .............. 402

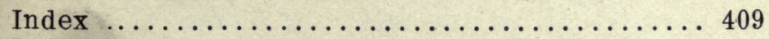





\section{GLOSSARY OF BOTANICAL TERMS.}

Acute-Terminating in a sharp point. Adventive.-Not perfectly naturalized. Alternate-Not opposite, but singly at different heights on the stem.

Annual-Of only one year's duration. Anther-That part of a stamen containing pollen. Appressed-Lying close and flat against.

Axil-Angle formed by a leaf and stem.

Basal-Leaves springing from the stem at the ground.

Biennial-Of two years duration.

Bilabiate-Two-lipped.

Bract-A small, modified leaf usually at the base of a flower stem.

Bulbous-Having underground leaf-buds with fleshy scales or coats.

Calyx - The outer perianth, or "cup" of a flower. Campanulate-Bell-shaped.

Cleistogamous-Fertilized in the bud, without the opening of the flower.

Composite - A compound flower head containing many tubular or ray florets. seated in a bracted, or scaly cup or involucre. (As daisy, thistle, etc.) Compound-Composed of several similar parts, or a leaf made up of several leaflets.

Cordate-Heart-shaped with the point upwards. Corm-The enlarged, solid bulb-like base of a stem. Corolla-The inner perianth of a flower, usually of petals as opposed to sepals of the calyx. Corymb-A flat topped cluster of flowers. 
xiv

\section{Preface}

Cross-fertilization-The pollen of one flower coming into contact with the stigma of another.

Creeping-A stem running along the ground and rooting at intervals.

Deciduous-Falling off; not evergreen.

Dentate-Toothed.

Disc Flowers-Tubular florets found in the centers of composite flowers.

Entire-Smooth-edged; no teeth or divisions.

Evergreen-Having green leaves at all times.

Fertile-Capable of producing fruit.

Fertilization-The quickening of the seed in the flow-

er ovaries by pollen from the anthers.

Filament.-The thread-like part of a stamen.

Floret-A small tubular flower, usually one of a cluster.

Glabrous-Smooth; not rough or hairy.

Glaucus-Covered wtih a whitish bloom.

Hirsute-Covered wtih rather coarse hairs.

Imperfect-Flowers with either stamens or pistil wanting.

Introduced -Brought intentionally from other regions.

Involucre-A cup-shaped cluster of bracts surround-

ing a head or flower cluster.

Irregular-With parts unequal in size or shape.

Lanceolate or lance-shaped-Much longer than wide;

pointed at the end and tapering at the base.

Leaflet-A single division of a compound leaf.

Linear-Long, narrow, with parallel margins.

Lip-Either division of a two-parted corolla; the broadened petal of an orchid.

Lobe-A rounded division of a flower or leaf. Midrib-The central vein of a leaf.

Naturalized-Floral immigrants that have become firmly established.

Nerve-A single, unbranched vein or rib. 
Oblong-Longer than broad, with nearly parallel sides.

Ovary-Part of the pistil containing seeds. Ovate-Egg-shaped, broad end downwards.

Palate-A rounded projection of the lower lip closing the throat.

Palmate-Radially lobed; spreading like the fingers of the hand.

Parasitic-Stealing nourishment from other plants. Pedicel-The stem of a single flower.

Peduncle-A flower-stalk supporting either a single flower or a cluster.

Perennial-One that lasts year after year.

Perfect Flower-One having both stamens and pistil.

Perfoliate-Leaf pierced by the stem.

Perianth-The calyx and corolla of a flower.

Petal-A single division of the corolla.

Petiole-The stalk of a leaf.

Pinnate-Compound, with leaflets arranged on each

side of a common petiole.

Pistil-The ovary, style and stigma of a flower.

Pistillate-Female flowers; pistils but no stamens.

Pollen-The life-producing grains in the anthers.

Raceme-Pediceled flowers growing along a more

or less elongated flower stem.

Radiate-Growing from or around a common center. Ray-The marginal flowers surrounding a disc.

Rib-A prominent vein of a leaf. Root-That part of a plant underground.

Scape-A leafless flower-stem rising from the ground.

Sepal-A division of the calyx. Serrate-Having sharp teeth pointing forward. Sessile-Without rootstalk, pedicel or petiole. Simple-Not compounded or branched. Spadix-A thick, fleshy spike usually in a spathe. Spathe-A large bract enclosing flowers. 
xvi

Preface

Spatulate-Rounded at the end and gradually narrowing at the base.

Spike-Sessile flowers on an elongated stem.

Spur-A nectar-bearing, hollow extension of some portion of a blossom.

Stamen-One of the pollen-bearing organs.

Standard-The upper, dilated petal of a pea-like flower.

Stem-The main ascending axis of a plant.

Sterile-Unproductive.

Stigma-That part of a pistil through which pollen effects an entrance.

Stipsule-An appendage, or bract, at base of petiole. Style-Connection between the stigma and ovary.

Tuber-A short, thick, underground root having numerous buds or eyes.

Tufted-Growing in clumps or clusters.

Umbel-A flower cluster with pedicels all from a common center.

Veins.-Thread-like branching nerves.

Whorl-Arrangement in a circle about stem. 


\section{WILD FLOWERS \\ EAST OF THE ROCKIES}

Their Construction, their Growth and their Manner of Living

Descriptions and Colored Plates of those Species conspicuous in Flower 


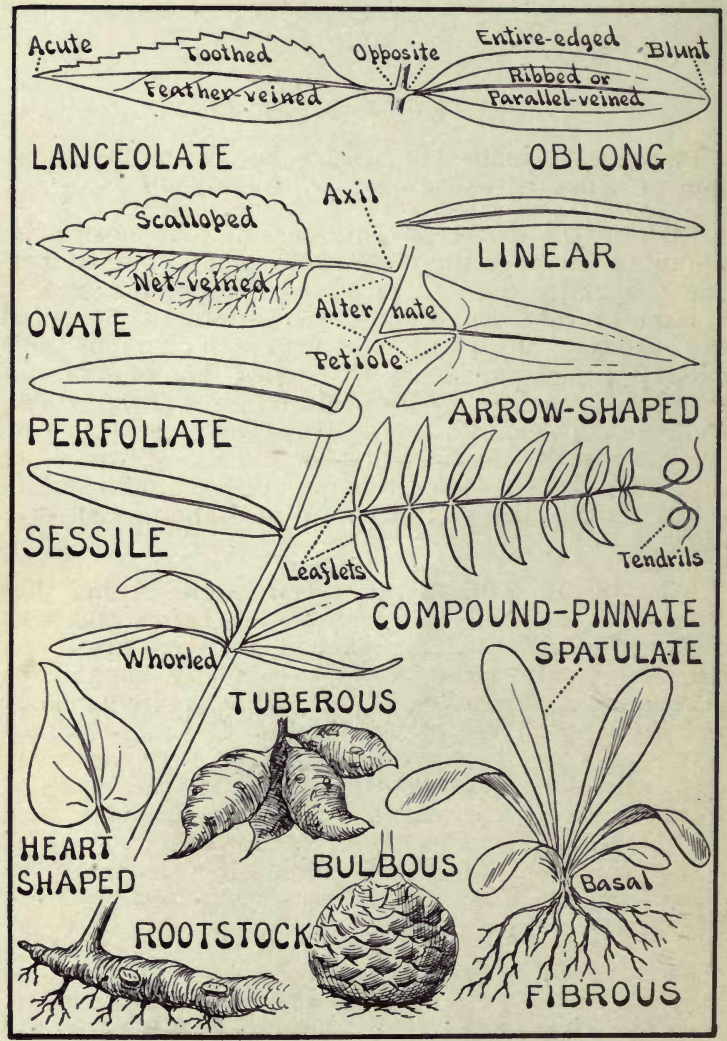




\section{PARTS OF PLANTS.}

Plants vary endlessly in turn but, with the exception of a few parasitic ones, all have roots.

FORMS OF ROOTS.-The form of root most often found on plants is the fibrous root, made up of numerous branching rootlets or fibres. The thick, fleshy, horizontal root found on most perennials is called the rootstalk; the plant stem grows in new positions each year, leaving scars to denote the locations of stems of previous years. Many grow from round Bulbs, composed of over-lapping fleshy scales; others have solid, fleshy bulbs, or Corms. Often roots give off what are called Stolens, underground running roots that at intervals throw up new plants and form new roots.

FORMS OF STEMS.-A Simple stem is one that rises from the root, with no branches before the flower or flower-cluster is reached. Stems are Erect when they are stout, stiff or perfectly capable of maintaining themselves in an upight position. They are Reclining when they are too weak to hold themselves erect. They are Prostrate or Creeping when they run along the ground, rooting at intervals, or from angles of the leaves; such stems usually turn up at the end or give off erect flowering branches. A plant is called stemless when the leaves all radiate from the base; in such cases the stalk bearing the flowers is the scape.

FORMS OF LEAVES.-Leaves are Linear when they are exceedingly narrow compared to their width, and the sides are practically parallel. They are 
Lanceolate when they are long compared to the width, are pointed at the outer end and taper towards the stem end, the greatest width coming near the stem. Spatulate leaves are rounded or bluntly-pointed, broadest near the tip and taper gradually to the stem. Leaves are Arrow-shaped if they have a Vshaped appendage on each side of the base; if these appendages are rounded, the leaves are called Auriculate. Other common forms are Heart-shaped, Oblong, Oval and Round.

Leaves are Entire-edged when they are neither toothed nor lobed; they are Toothed when the edges are regularly and angularly notched; they are Scalloped when these teeth are rounded.

When a leaf has rounded projections on its edge, it is said to be Lobed; when these projections are angular, it is said to be Incised. A leaf made up of several smaller ones is Compound.

A leaf is Palmately-compounded or Palmately-lobed when the leaflets, or the lobes, radiate from a common center. A compound leaf is Pinnate when the leaflets are regularly arranged on either side of a common stem or axis; when each of these leaflets is also pinnate, the entire leaf is said to be Bipinnate.

A leaf stem is called its Petiole. Leaves that have no stems, but are seated directly upon the plant stem, are said to be Sessile. If the plant stem apparently pierces the leaf, the latter is Perfoliate. Two leaves appearing, one on either side of the stem, at the same height are opposite. If three or more leaves appear about the stem, at the same height, they are Whorled. Alternate leaves are those appearing regularly along the stems at different heights. If the leaf should clasp the stem with its base it is said to be Sheathing. 
Bracts are small leaves that appear oftenest at the junctions of flower stems with the stalk. Stipules are small bracts often appearing where a leaf petiole joins the stem.

FORMS OF FLOWERS.-A Perfect flower is one that has a pistil and stamens. The Pistil is usually in the center of the blossom; it is composed of the Ovary, containing the seeds, usually located at the base; of a Stigma, for the reception of pollen, usually at the summit of the pistil; and of a Style, this being the, usually, slender connecting link between the sigma and the ovary.

Stamens usually radiate from the base of the pistil. At their ends we find enlargements or little cases called the Anthers; these contain fine, dust-like particles called Pollen.

A simple, regular, perfect flower has a Calyx, the outermost part of the floral envelope, divided into four or five parts each being Sepal, a Corolla, the inner part of the floral envelope, divided into four or five parts called the Petals, a pistil and four or five stamens. This is the most simple form of flower; from it there are endless variations. Some have one of the petals enlarged, dilated, twisted or broadened into some unusual form as shown in the Orchids, others have two or more of the petals united as in the Pulse Family; or again, the sepals and petals may be uniform in size, shape and color as in the Lilies, the whole forming what is called the Perianth.

Reference to the plate of Flower Forms will give one a much clearer idea than would text in regard to the outlines of flower shapes commonly found. A single flower, or flower head, at the end of a simple 


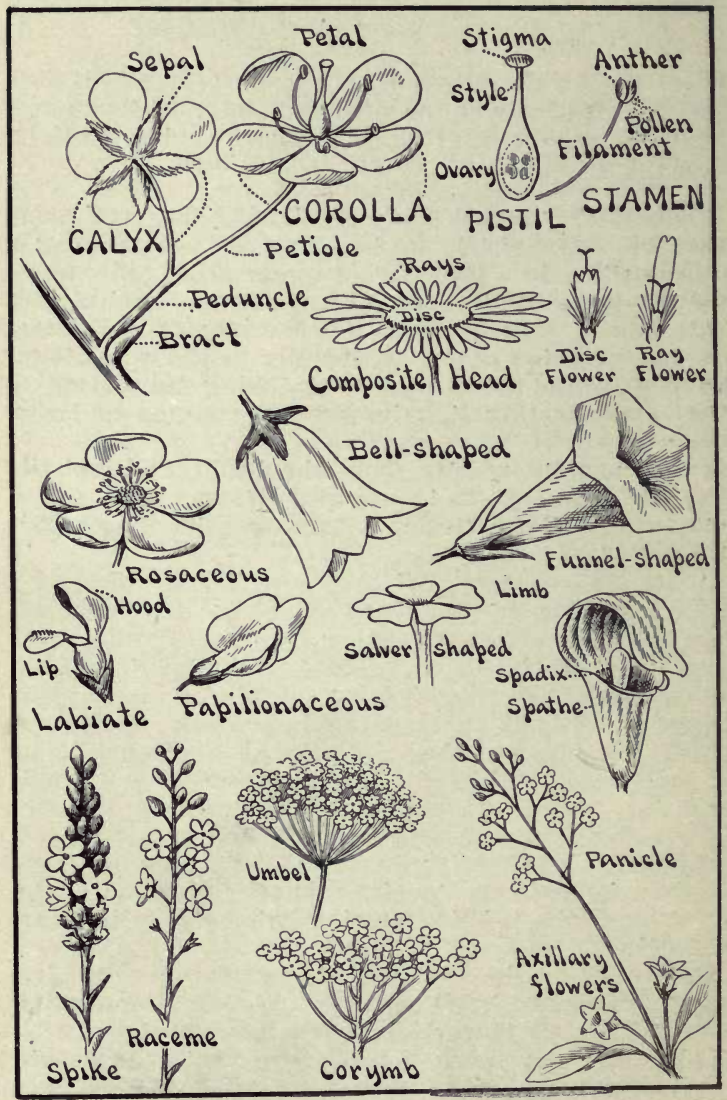


stem is called Solitary and Terminal. If several are grouped together, they are in a Cluster. Clusters or solitary flowers may occur at the ends of branches or from the angle formed by a leaf and the stem, in which case they are said to be Axillary.

Clusters of flowers assume different forms.

When the blossoms are distributed along the upper part of the stem, each on a slender pedicel and at different heights, they are in a Raceme, if they are so distributed, but the flowers are stemless the formation is said to be a spike. If the cluster is rounded or hemispherical, the flower pedicels all radiating from a common point, it is said to be an Umbel. If the cluster is rather flat on top and the pedicels meet the axis at different points, it is a Corymb. If the end of a stem is enlarged, thick and fleshy, and has tiny flowers grouped on its surface, it is a spadix. If this spadix is enclosed in a leafy or fleshy protection, the latter is a spathe. 



\section{METHODS OF REPRODUCTION OF PLANTS.}

All living creatures are so constructed as to be capable of reproducing their kind. In fact, with all the lower Orders, that is the one object in their life. We have seen that flowers have stamens and pistils. These are the reproductive organs; the calyx, petals, nectar and fragrance are for other purposes as we shall see later.

The simple pistil is composed of three most important parts: At the summit is a stigma, this usually being sticky; just below is a slender tube called the style; at the base, the pistil is enlarged or swollen and contains the ovules or undeveloped seeds. The simple stamen is composed of a slender filament supporting at its end a little case or enlargement containing a fine powder-like substance called pollen.

The relationship between the pistil and the stamens was first discovered by a botanist named Grew, in the 17th century. His discovery, later confirmed by Linnaeus, was that in order for the seed to be developed, pollen from the anther must come in contact with the stigma, thence being transmitted through the style to the seeds below and quickening them to life.

Many puzzling propositions occurred, that these scientists were unable to unravel,-as,- "if the stamens were shorter than the pistil, how could the pollen ever reach the stigma?" It remained for Sprengel, late in the 18th century to declare that pollen was carried from the anthers to the stigma by insects 
while feeding on the flowers. He also discovered that the corolla, often brightly colored, was for the purpose of attracting insects and the nectar was for their food; fragrance also was a factor in drawing about the useful insects and, often, lines on the corolla or petals directed the visitor to the supply of food at the base.

It remained for the great Darwin to discover the exact truth about the many complicated methods of fertilization. Whereas Sprengel had supposed insects simply transferred pollen from the anther to the stigma on the same flower, Darwin claimed that it was of vital importance that the pollen from one blossom should be left at the stigma of a different one, and that many flowers were so constructed that they were incapable of being fertilized by their own pollen.

Nature's plan is to disperse families in order to prevent interbreeding, the continuance of which decreases vitality. All plants are slowly developing schemes for insuring cross-fertilization. Many flowers now are self-pollenized, but all first offer the opportunity to insects of various kinds to perform that office for them, and flowers so cross-pollenized will be stronger and healthier than the others. In ages to come, we may expect that, through the gradual elimination of the weaker, all species will be incapable of self-pollenization.

Methods for the preventing of self-pollenization are numerous and varied. The simplest is in having the anthers or stigma mature, one before the other. Many ingenious devices locate these members where they may not come in contact with one another, and so that an incoming insect will first touch the stigma and then, as he is departing, be showered with or 
have masses of pollen attached to some portion of his anatomy.

Many plants, usually annuals, whose roots die each year and that are dependent entirely upon setting of seed for their existence, have what are called cleistogamous flowers. These are bud-like flowers that never open, but fertilize themselves in the bud. These plants also have flowers that do open and that try to woo insect visitors; the others are for protection in case of several years shortage of useful insects.

Just as some flowers are so careful in adajting themselves to certain useful insects, they must be just as careful in protecting themselves against useless ones. In general, smooth bodied insects are of little value to plants, but they all like nectar. The most useless visitors are crawling ones, especially ants and it is against these that plants must erect their barriers.

The most frequently used preventative is a downy stem. The small hairs impede upward progress and often exhaust the tiny insects before they can reach the flower; often the calyx is sticky and the marauder finds a barrier from which he must turn or risk being caught on its surface. Some flowers have their nectar in long slender tubes so that only moths, butterflies or long-tongued bees can reach it. Others have the entrance closed with a palate, to open which the weight of a bee on the platform outside is necessary. Still others, like the Closed Gentian, are always closed, but the petals can be forced apart by the strong bumblebee.

Many flowers are very highly specialized,-adapted to be fertilized by but one species of insect. This 


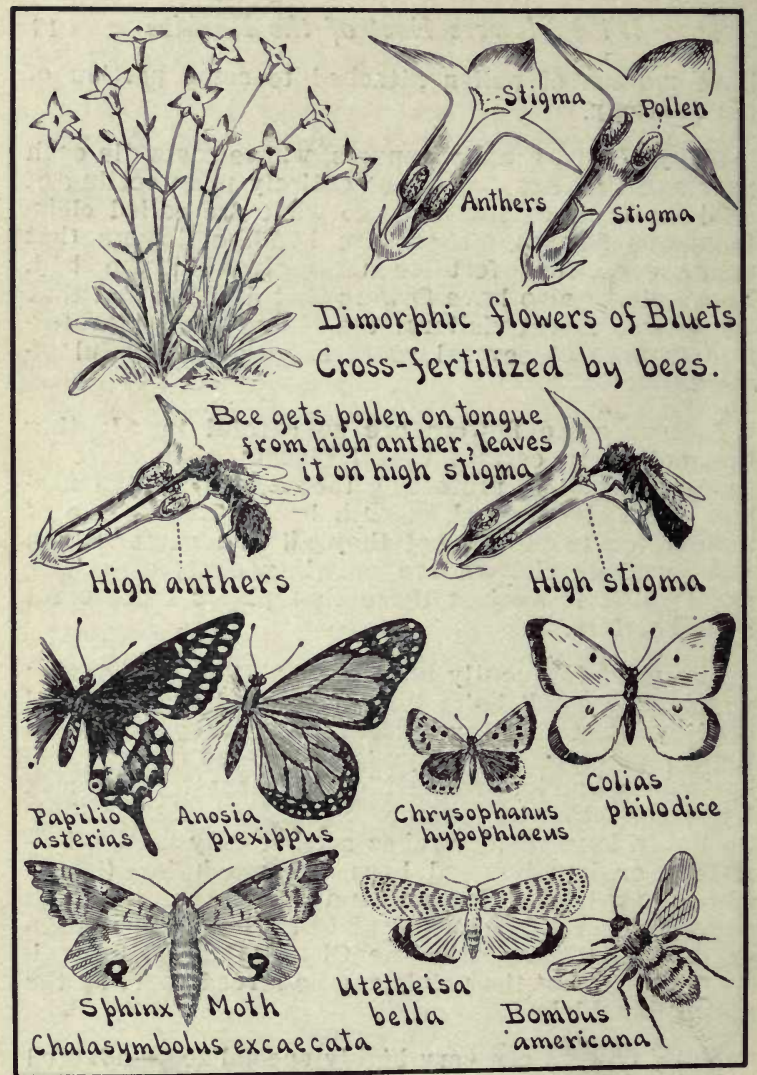


specialization is carried to the highest degree in the great Angraecum Orchid of Madagascar, that has a nectar tube eleven inches in length. But one insect, a huge sphinx-moth, has a tongue of sufficient length to drain this nectary and to this insect alone, the plant owes its existence. It is related that Darwin, being confronted with the evidence of this flower against one of his theories, claimed that such a moth lived, even before it had been discovered.

The seeds having been matured must be dispersed. The simplest method is simply allowing them to drop to the ground; a better one is to provide for their spreading, this constantly widening the range of a species and making a stronger race by bringing together widely distant families.

We have all seen the rough-coated milkweed pods that burst open in the Fall and release quantities of silky-winged seeds. This flossy subtance is not for ornament; neither is it designed to amuse children. Each seed has an airy parachute that often carries it miles from the scenes of its birth before it finally comes to earth. This method is perhaps the simplest and best for wide dispersal; many flowers have adopted it,-thistles, dandelions, etc. Others nave seeds in pods, like touch-me-not, that explode when they are matured and scatter the seeds over an area of several square yards. Still another method is of having tiny hooks, like the seeds of the genus Bidens, or in burs, like the burdock, that attach themselves to the hair of passing animals or the clothing of persons, and travel, perhaps, miles before they are shaken or brushed off. 


\section{EXAMPLES OF SPECIALIZED FLOWERS.}

By specialized is meant flowers that are incapable of self-pollenization.

The common apple or pear blossom is a regular, simple and perfect flower. The stamens surround a single central pistil; the anthers, however, mature before the stigma develops, so pollen of a blossom will have no effect should it fall upon the stigma of the same flowers. It is not specialized to the extent of being dependent upon a certain insect, but welcomes all kinds of bees.

Alighting in the center of the blossom, the bee commences to drain the base of nectar; as he turns this way and that, in order to get all of it, the anthers dust him well with pollen and off he flies to the next flower, perhaps one in which the stigma is ripened; as he lands in the center some of the precious pollen is left on its sticky surface and his mission, as far as the blossom is concerned, is completed.

Bluets, the tiny blue and white flowers that grow so very abundantly in dry fields, have an interesting lesson to teach us concerning plant ways. It is an excellent example of a "dimorphic" plant, - one having two kinds of flowers. These different flowers do not grow on the same plant, nor usually in the same clump. The little pictures on the plate will serve to show the different forms of the flowers, better than I can describe them. Examine one little clump carefully and you will find four little yellow anthers in a 
slight enlargement near the mouth of the corolla tube, and almost blocking it; further examination of this flower will disclose a short pistil with a forked stigma in the lower part of the tube. Carefully look over other clumps and you find some in which the divided stigma will appear at the throat, in place of the Anthers found in the first instance. You will also notice that the corolla tube, in this last instance, contracts a little just above the base; just above this contraction we will find the four anthers.

The anthers and stigma in each flower mature at the same time, yet the flower cannot fertilize itself; the pollen grains of anthers at the top of the tube, are larger than those in anthers located near the base. The pollen from the high anthers will not quicken the seed of a low pistil, neither will that of a low anther accomplish this result with a high piltil.

Thus it is absolutely necessary that the life-giving germs be carried not only from one flower to another, but usually from one clump to another. Bees and small butterflies commonly visit bluets, the bees, with their larger tongues, being the most serviceable; as he sips the nectar from the cup, if a highanthered one, he gets pollen on his tongue near the face; if a low-anthered flower, the pollen is attached near the tip of the tongue. In either case it will be left at the door of the first flower he visits of the opposite kind.

Nearly any flower that we may chance to pick will have its story to tell to the sharp-eyed,-more interesting than fiction can relate, because they are truths. We may learn how the Mountain Laurel has its pollen on tiny springs waiting to clap it at the 
proper moment on the body of a visiting insect. The milkweed will show us how its pollen masses are connected in pairs; how the legs of butterflies and bees become caught in the sharp angle of this connecting link; how the pollen masses are torn from their sheaths and carried to another blossom, a reverse operation freeing the insect from the valuable part of his burden and leaving it at its proper destination; and, alas, how many insects, not strong enough to free themselves, perish in this trap.

The Orchids, wonderful creations, and the most highly specialized of all our flowers, each being adapted almost exclusively to a certain species of insect, will show us their ingenious methods of plastering their pollen masses to the eyes or the tongues of their visitors.

This study of the reproduction of plants offers a very wide field for investigation, a field much different from the old botanist, concerned only in the dissection of specimens. It calls for study in the field, a study of Life, a study that is worth while. 


\section{Wild FlOWERS}

East of the Rockies 


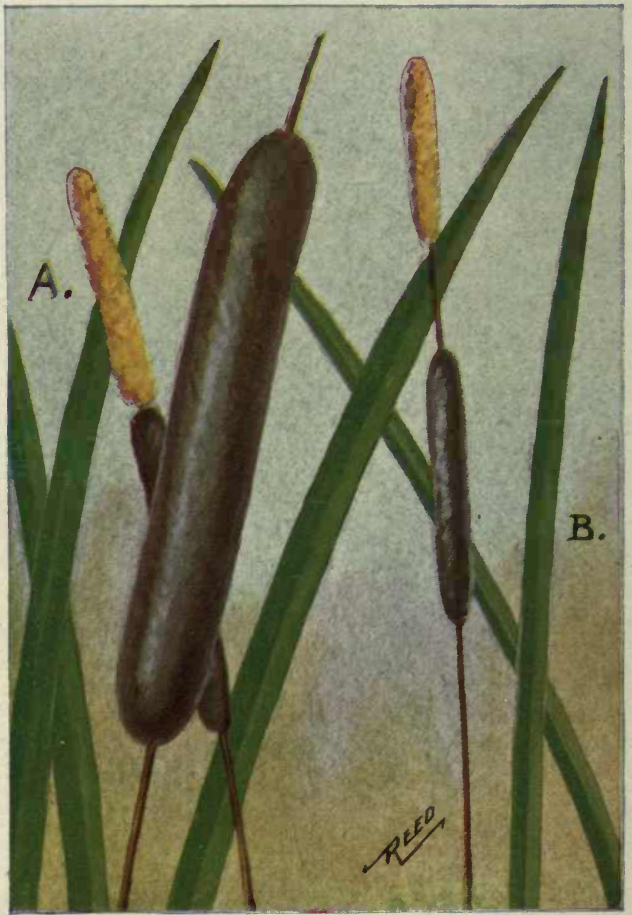

A. Common Cattail Typha latifolia.

B. Narrow-leaved Cat-tail. Typha angustifolia. 


\section{CAT-TAIL FAMILY (Typhaceae).}

The members of this family are very abundant aquatic herbs with perennial roots. Sometimes we find them in groups of only two or three plants, and again acres of marsh may be covered with waving green leaves. We have two species with differences as noted below. Both have staminate yellow flowers in a spike above the pistillate brown ones; the former soon fall off or blow away, while the latter develop into the large, familiar, brown cattail that is often used for decorative purposes. These plants are self fertilized by the pollen from the staminate flowers falling upon the stigmas of the pistillate ones below.

Tracts of cat-tail marshes usually furnish homes for various species of birds. The Marsh Wren attaches its handsome globular nest to the rushes a few feet above water; Least Bitterns fasten their rude platforms also in the leaves, while rails, coots and grebes find appropriate places among the roots on the ground, at the waters edge or even floating upon the surface of the water. The two species of Cat-tails that we have, differ as follows:

COMMON CAT-TAIL (Typha latifolia) has yellowish staminate flowers encircling the upper end of the flower stalk, and immediately below is a long cylindrical mass of brownish pistillate ones. The pollen grains are arranged in fours. Leaves three to eight feet long, sheathing at the base. Found in marshes throughout the United States and southern Canada, flowering in June and July.

NARROW-LEAVED CAT-TAIL (Typha angustifolia) has narrower leaves, averaging less than $3 / 4$ in. broad. The two kinds of flowers are separated by a bare space of stalk and the pollen grains are simple. This species is locally found from Me. to Mich. southwards, chiefly near the coast. 


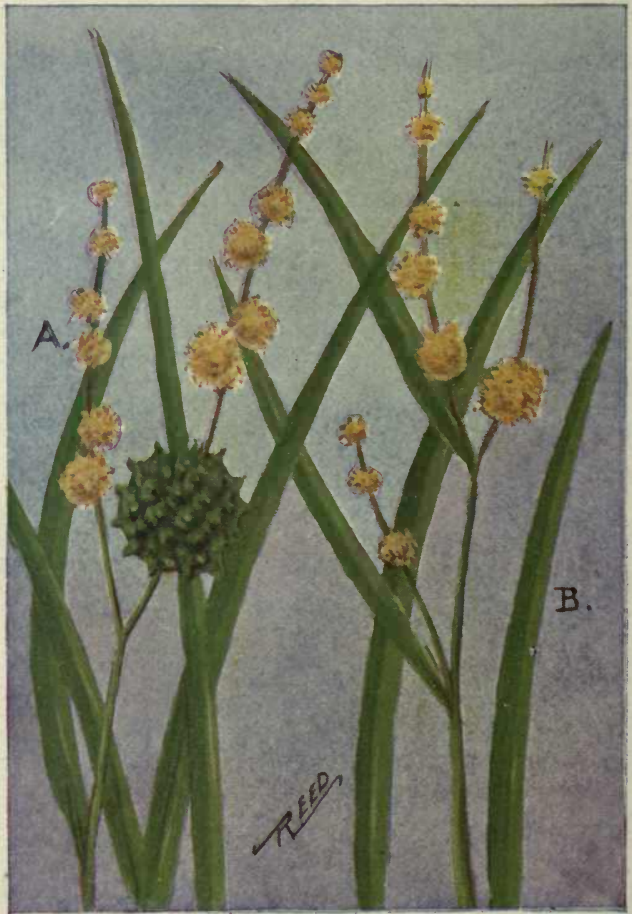

A. Great Bur-reed.

Sparganium eurycarpum. B. Branching Bur-Reed. Sparganium androcladum. 


\section{BUR REED FAMILY (Sparganiaceae).}

The Bur Reeds are marsh inhabiting plants, some growing along the muddy shores of ponds or streams, while other species are strictly aquatic, growing in the water with floating leaves. Like the Cat-tails they are not in the least dependent upon insects for fertilization. The two kinds of flowers, staminate and pistillate are always in separate spherical clusters, usually alternately arranged along the stem. While the upper flowers are developing, the middle ones are in full bloom and the lower ones have been transformed into spherical prickly fruit. Several varieties of Bur Reed are recognized, the ones here mentioned being the most common and the most characteristic.

GREAT BUR-REED (Sparganium eurycarpum) is stout and erect, two to three feet in height. The mature heads, or fruit, are about one inch across; composed of wedge-shaped nutlets arranged in the form of a sphere, giving the outside a corrugated appearance similiar to the surface of a pineapple. The basal leaves are similar to those of the Cat-tail and clasp the stems at their bases. These plants are found in the whole of the U. S. and southern Canada, flowering from June to August.

SMALL BUR REED (S. simplex) is smaller in every respect; leaves shorter and narrower and the greenish fruit head less than $3-4$ in. in diameter; the nutlets are very sharply pointed. This species is found in northern U. S. and southern Canada.

BRANCHING BUR REED (S. androcladum) throws off several weak flower-bearing branches from the angles of the upper leaves.

LEAST BUR REED (S. minimum) is slender and ten to eighteen inches high; leaves grass-like, floating on the water; northern U. S. and Canada. 


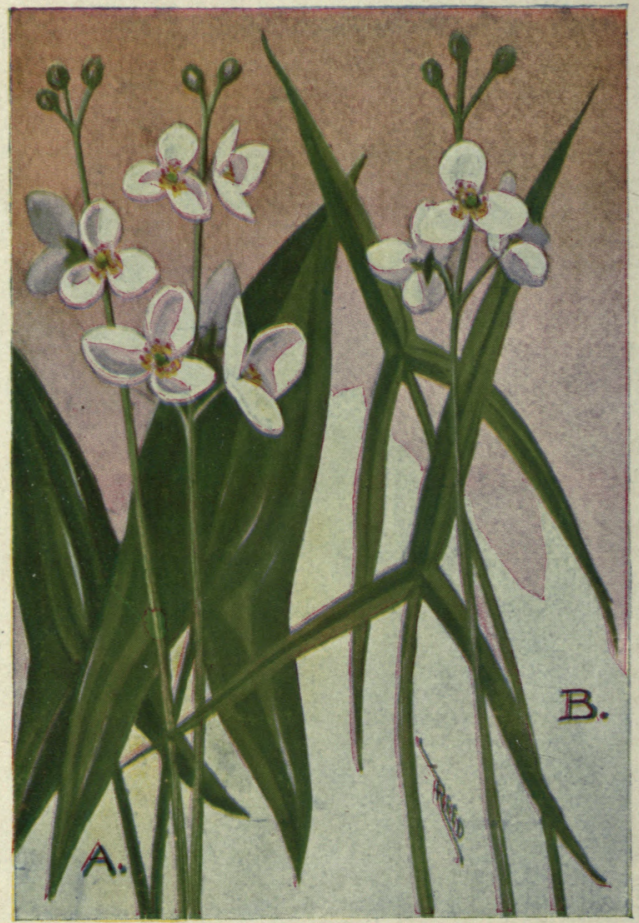

A. Broad-leaved Arrow-head.

Sagittaria latifolia.

B. Narrow-leaved Arrow-head.

Sagittaria Engelmanniana. 


\section{WATER PLANTAIN FAMILY (Alismaceae.)}

GENUS ARROW-HEAD (Sagittaria.) Arrow-heads or Sagittarias are among our most beautiful water plants. The leaves vary greatly in shape but are always graceful in appearance. All species have three pure white petals with a golden center formed by the large anthers. The following are the most distinctive of the twelve species now recognized in Gray's Botany. They usually grow in the water but sometimes on the muddy shores, and flower in June or July. Except as noted, these species are common in the U. S. and southern Canada.

BROAD-LEAVED ARROW-HEAD (Sagittaria latifolia) has broad arrow-shaped leaves on long petioles from the root. The 3-petalled white flowers grow in whorls of three, the upper ones being staminate and the lower pistillate. Seed, winged on both edges and with a twisted horizontal beak. This species is smooth but a variety, ( pubescens) has the stem quite wooly. Common in the whole of our range.

NARROW-LEAVED ARROW-HEAD (S. Engelmanniana) has very narrow leaves with linear sagittate bases. The seeds are winged but the beak points upwards instead of being bent at an angle as in the last.

LANCE-LEAVED SAGITTARIA (S. heterophylla) has lance-shaped leaves with usually no sagittate appendages to the bases. The seed is round, winged and with a vertical beak. This species is found from Me. to Minn. and southwards.

GRASS-LEAVED SAGITTARIA (S. gracillima) has linear, grass-like leaves and grows wholly under water. In July a long slender flowering stem reaches to the surface and floats the small, 3-petalled white flowers. Found locally in the East. Used extensively in aquaria as it is an excellent oxygen giver. 


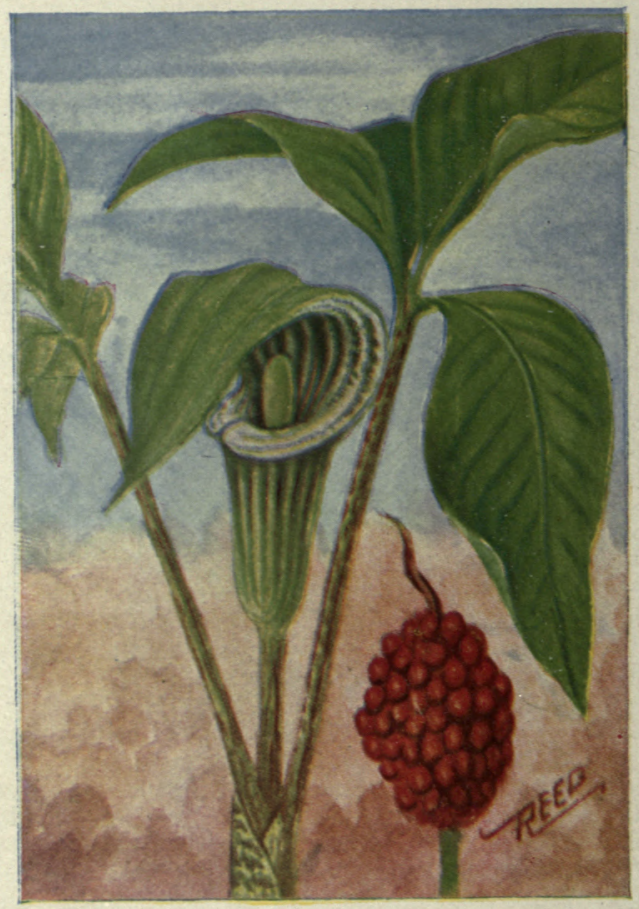

JACK-IN-THe-PulPit.
Arisaema triphyllum. 


\section{ARUM FAMILY (Araceae).}

This is quite a large family of plants containing six genera. All have acrid or pungent juices; flowers closely crowded on a spadix, usually surrounded by a spathe; leaves either simple or compound and of various shapes.

\section{Genus (Arisaema).}

JACK-IN-THE-PULPIT or INDIAN TURNIP (Arisaema triphyllum) is the most abundant and the best known representative of this genus. In most all moist woods and often in unexpected shady nooks, you will find Jack, represented by the spadix, looking out at you from his pulpit, represented by the spathe of the flower. The spathe is light green, more or less striped with brown, especially on the inside; the spadix is also green and has the tiny flowers clustered about its base. The flowers are sometimes of both kinds on one plant, but usually the stamens will be found on one and the pistils on a different one, thus insuring cross-fertilization, which is accomplished chiefly by small flies and gnats. The inside of the spathe is very slippery, as is also the spadix, so that many insects are unable to crawl up its sides and perish within. The large solid roots are very acrid and fiery to the taste, but are said to have been relished by the Indians, although they are now often used in the concoction of medicines. Usually two, thrice-compounded leaves spread shelteringly over the flower spathe on long stems. Large clusters of bright berries remain after the leaves have withered. Flowers throughout U. S. from April to July.

..GREEN DRAGON (Arisaema dracontium) has one leaf divided into ten radiating pointed leaflets on a long stem, sheltering the flowers clustered at the base of a projecting spathed spadix. 


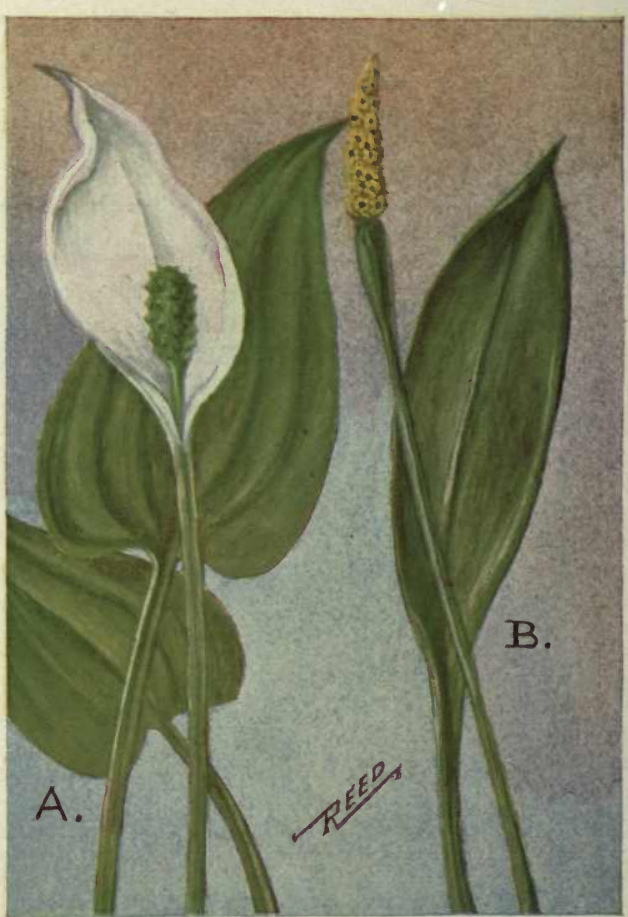

A. Water Arum.

Calla palustris.

B. Golden Club.

Orontium aquaticum. 
WATER ARUM (Calla palustris) is our only representative of its genus. It is quite a common plant in cool bogs, where it grows from six inches to a foot in height. The root stalks are perennial and branch out through the soft mud, continually throwing up new plants, until shallow ponds may become completely carpeted with the beautiful dark green, heart shaped leaves. The leaves stand above the water on long petioles. This plant is distinguished by a beautiful, waxy-white, spreading spathe that is often mistaken for the flower.

The true flowers are small and perfect, clustered at the end of a yellow spadix. They give forth a rather disagreeable odor that attracts to them numerous little flies that assist in pollenization, although the plant is capable of self-fertilization..

Each plant usually has but two leaves. The flowering season is in' June; in August they have been transformed into clusters of red berries. You may find this plant commonly in cool bogs from N. J. and Mo. northwards.

GOLDEN CLUB (Orontium aquaticum) is also our only member of its genus. As you will see by the opposite picture, there is no protective spathe for the golden floral club, yet it flourishes equally as well as its more fortunate relatives.

The florets are complete, having six sepals and stamens; they are set closely on the swollen spadix and attract many flies and even water snails that cross-fertilize them simply by crawling over the clubs.

While there is no apparent spathe about the flower spike, it appears a little lower on the stem as a leaflike. sheath. The leaves of the Golden Club are pointed oblong in shape, floating on the surface of the water by means of long stems from the perennial rootstalk. Flowers in May from Mass. to Fla. and westwards. 


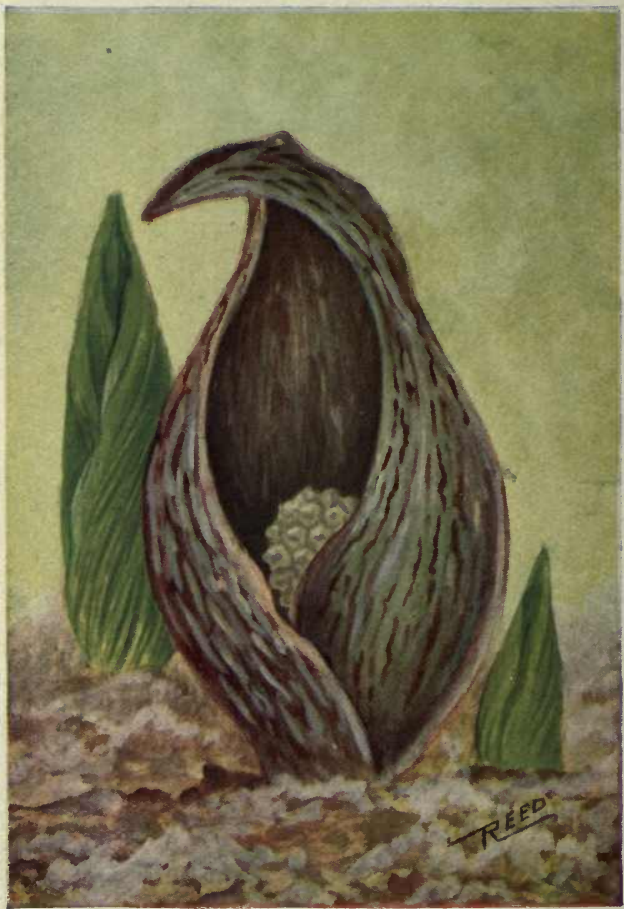

Skunk Cabbage.

Symplocarpus foetidus. 
Wild Flowers East of the Rockies

\section{Genus (Symplocarpus).}

The common SKUNK CABBAGE (Symplocarpus foetidus) although regarded by many only with disgust, has one claim that cannot be disputed, that of being our first flower to bloom each year. It is not uncommon to find them with the shell-like spathe above ground and the pollen fully ripened even in January although from the latter part of February to the first of May is the usual flowering season.

While the ground is covered with snow, a tiny awl point thrusts its way through the hard earth and slowly enlarges and expands, until, by the time the melting snow gives us our first glimpse of the ground, we find the skunk cabbage fully developed and awaiting its insect visitors. The first warm days bring forth quantities of small flies, many of which have simply been dormant beneath the leaves. These flies feed upon decaying animal matter; they have no æsthetic taste and beautiful flowers would lack the attractiveness to them that the ill-scented skunk cabbage has. We must conclude that this odor, combining that of the skunk and of putrid meat is for the purpose of attracting carrion flies that they may perform the function of fertilizing the flowers.

The flower spathes show a very great diversity of coloring according to their age, ranging from a pale green sparingly streaked with brown to an almost solid purple tone.

The flowers are small, perfect and closely crowded on the thick fleshy spadix, concealed or partially so by the large, thick. purple and green stained hood; The leaves appear after the flower has withered or commenced to do so; they are bright green, large, cabbage-like, and strongly veined; quite handsome, in fact. These plants range from N. S. to Minn. and southwards, chiefly in boggy ground. 


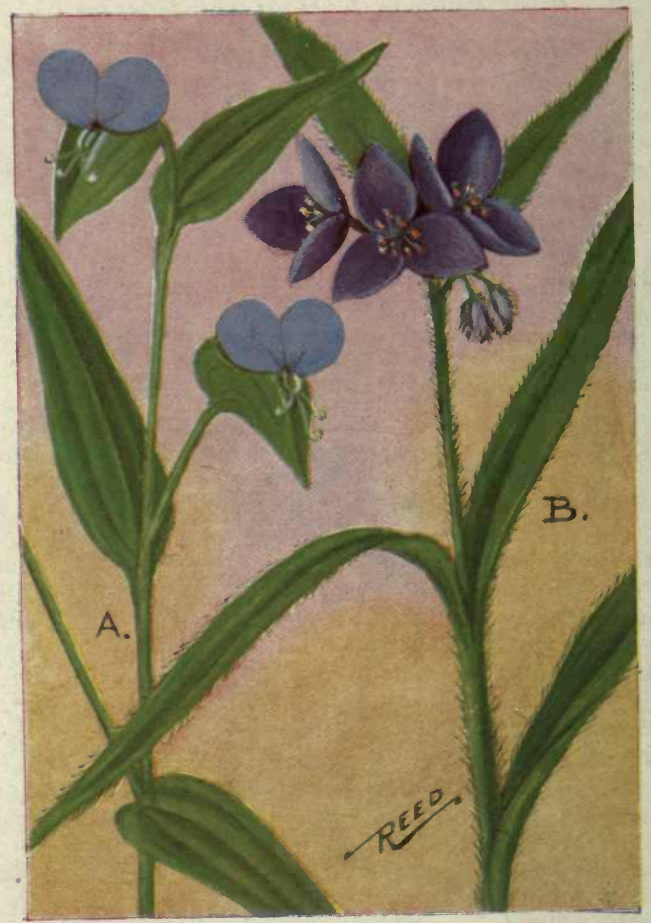

A. Day-Flower.

Commelina communis.

B. SPIDerwort.

Tradescantia virginiana. 


\section{SPIDERWORT FAMILY (Commelinaceae).}

A small family of herbs containing, in our range, about a dozen species under two genera.

DAY-FLOWER (Commelina communis) is one of a very few of our native plants having pure blue flowers. Its common name is very appropriate because each blossom lasts but a single day, opening in the morning, and before night, shrinking away to a little mass of jelly. Its generic name was given by Linnaeus in honor of a Dutch family of botanists by the name of Commelin. It flowers all summer and spreads rapidly by striking out new roots from the leaf joints on the reclining stem.

The stem is rather weak, much jointed and attains heights of one to two feet. The leaves are lanceshaped clasping the stem at its joints. The flowers have three irregular sepals and three petals; two petals are large, rounded and blue, while the third is tiny and colorless; three stamens are sterile and have no anthers, while three others are fertile, with orange anthers; the whole flower peeps out from a clasping, cordate, heart-shaped leaf or spathe. Found from Southern Mass. to Mich. and southwards, blooming in rich woods or dooryards from June to Sept.

SPIDERWORT; JOB'S TEARS (Tradescantia virginana), like the Day Flower, remains open but for part of a day, after which the petals contract into glutinous drops, thus giving it one of its common names. The generic name was given in honor of John Tradescant, who was gardener for King Charles the First.

The stem is hairy and sticky; from one to two feet high. The leaves are linear, hairy and clasping at their bases. Three purple petals, three brown, hairy sepals and six orange tipped stamens compose the flowers. They may be found in rich soil from Me. to Mich. and southwards, flowering from June to August. 


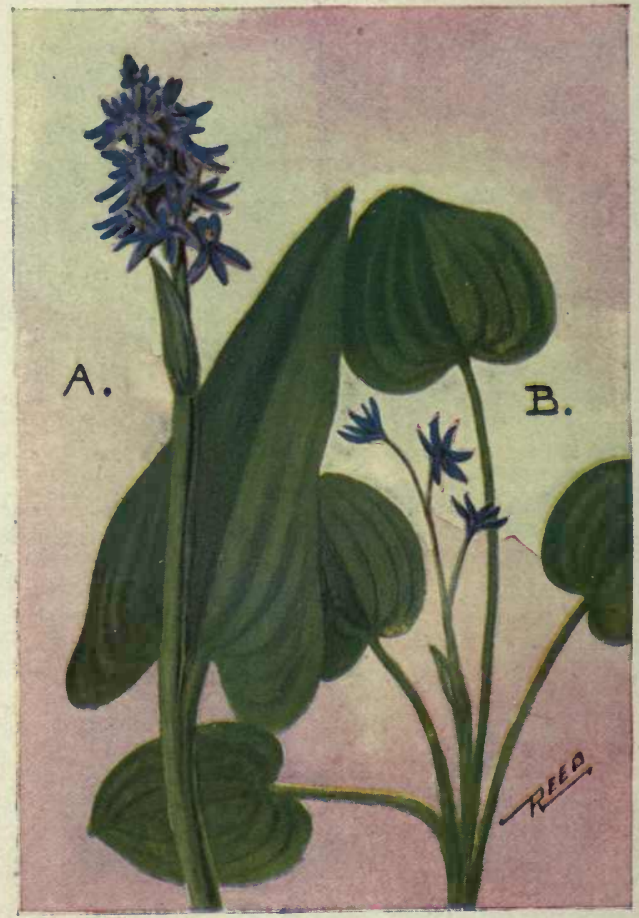

A. Pickerel-weed.

Pontederia cordata. B. Mud Plantain. Heteranthera reniformis. 


\section{PICKEREL-WEED FAMILY (Pontederiaceae.)}

A small family of aquatic plants consisting, in our range, of only four species grouped under two genera.

PICKEREL-WEED (Pontederia cordata) is an exceedingly abundant water plant, growing profusely in shallow ponds or along the edges of fresh water streams, and flowering from June to Aug. Its name is derived from the habits of pickerel in concealing themselves beneath its leaves.

The flowers grow on a spike that proceeds from a small, green, leaf-like spathe; the 3 upper divisions of the 6-parted perianth are partially united, but the 3 lower ones are spreading; in color they are a light violet blue, with two yellow spots at the base of the upper united parts. Each flower lasts but a single day, but new ones continually appear on the lengthening stalk so that continual bloom exists throughout the summer. A single heart-shaped, cordate leaf clasps the stem about midway, while others on long petioles grow from the rootstalk. They are blunt tipped, deep glossy green, and stand above the surface of the water. Commonly found from N. S. to Manitoba and southwards.

MUD PLANTAIN (Heteranthera reniformis) has a slender, few-flowered spike proceeding from a small sheath-like spathe. The perianth is blue and regularly 6-parted. The three stamens are unequal, two being tipped with yellow anthers and the third with a greenish one. The leaves are round-lobed, kidney-shaped, floating on long stalks from the root. Found from Ct. to Neb. and southwards.

$H$. dubia has a single yellow flower with equal stamens and grass-like leaves. It is found throughout the United States and southern Canada. 


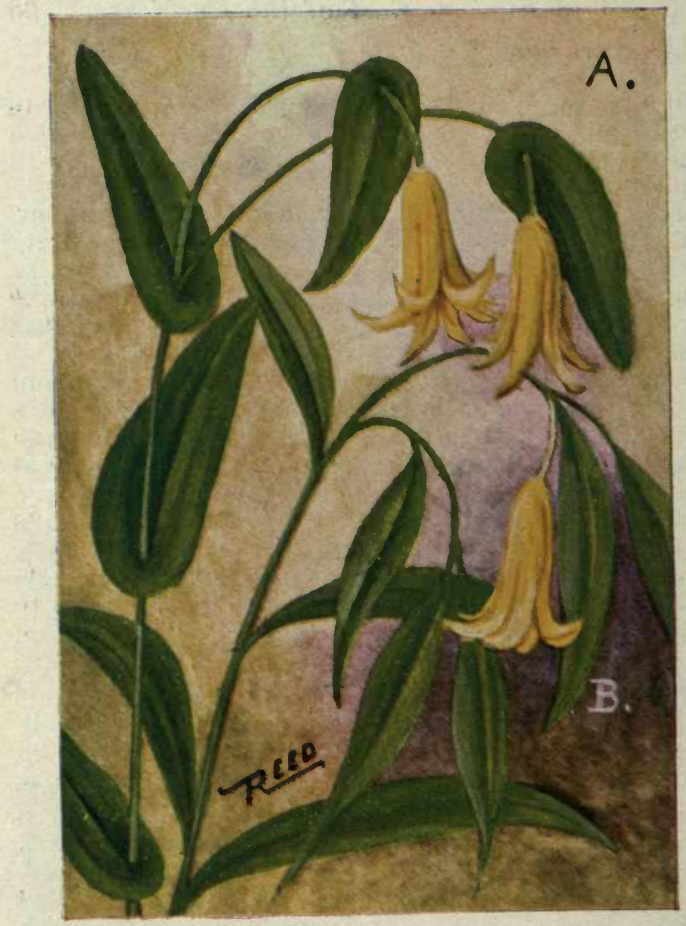

A. Bellwort.

Uvularia perfoliata.

B. Wild OAts.

Oakesia sessifolia. 


\section{LILY FAMILY (Liliaceae).}

This is an exceedingly large family containing more than 80 species in our range, divided into 33 genera and 13 different tribes. Many of these rank as among our most beautiful flowers. They usually agree in having a 6-parted perianth and 6 Stamens.

BELLWORT (Uvularia perfoliata) is common in rich woods. The stem, that reaches a length of 6 to 18 in., rises from a short rootstalk; it has scale-like bracts near the base and forks toward the top. A single, straw-colored flower is pendent from the end of each drooping branch; it is long, bell-shaped and has six narrow divisions and six stamens much shorter than the perianth and shorter than the style. The leaves are light green, lance-shaped and pierced by the stem; usually three below the fork in the stem. The flowers are slightly fragrant and so concealed by their drooping position as to be invisible from above. They blossom in May and June; found throughout the U. S.

LARGE-FLOWERED BELLWORT (U. grandiflora) has larger flowers; stamens longer than the style and but one leaf below the fork in the stem. It is found from N. H. to Minn. and southwards.

OAKESIA; WILD OATS (Oakesia sessifolia) has an angular stem from 6 to $14 \mathrm{in}$. long. The ovate-lanceolate leaves are seated on the stem and not pierced by it. One or two flowers are suspended opposite the leaves near the end of the stems; they are similar in size and coloring to those of Bellwort but the interior is smooth while the latter has rough ridges. This species is common from Me. to Minn. and southwards.

O. puberula is slightly downy. The leaves are bright green with no glaucus effect. It is found in the pine barrens from N. J. to S. Car. 


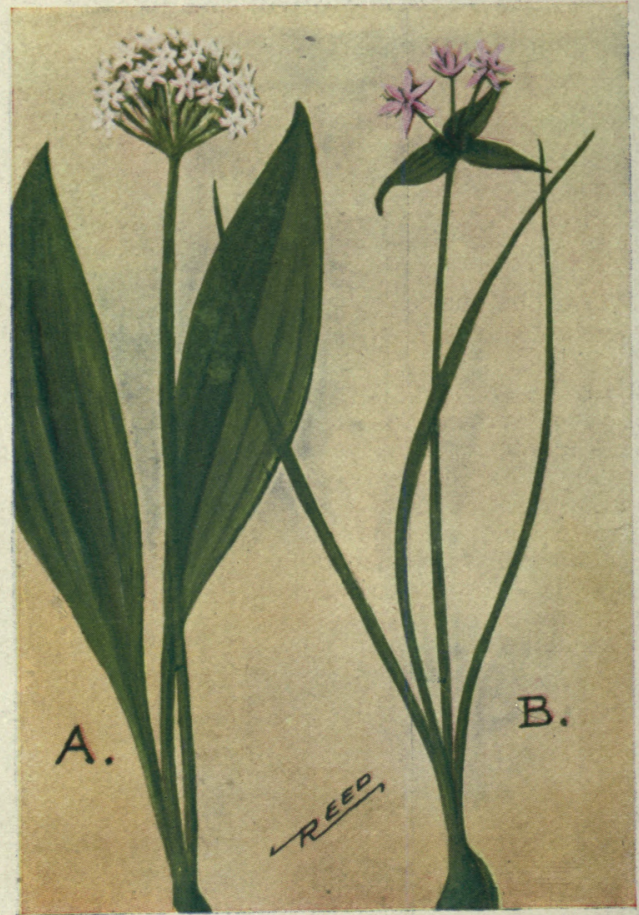

A. Wild Leek. Allium tricoccum.

B. Wild Garlic. Allium canadense. 


\section{Wild Flowers East of the Rockies}

\section{ONION; GARLIC Genus (Allium).}

The various species belonging to this genus are very strongly scented, pugent herbs growing from a coated bulb. The flowers grow in an umbel at the top of a long scape that is sheathed towards the base, by the leaves. The Wild Leek is peculiar in that the long, broad leaves usually wither away before the flowers appear. The six-parted flowers, that comprise the cluster, are rich in honey and are frequented by various species of the smaller bees. This species is found in rich woodland while the other members of the genus inhabit moist fields or marshes.

WILD LEEK; WILD ONION (Allium tricoccum) is a woodland plant blooming in May and June. The flowers are in an umbel at the top of a scape 6 to 20 in. high. The flower perianth is divided into six greenish-white sepals. The leaves are oblong-lanceshaped, pointed at both ends, on long petioles from the bulbous root, but usually withering before the flowers appear. Found from N. B. to Minn. and southwards.

A. cernuum has fewer, purplish flowers nodding in a loose umbel at the top of a longer scape. The leaves are linear. It is found from N. Y. to Mich. and southwards.

WILD GARLIC (Allium canadense) has few purplish, 6-parted flowers on slender pedicels from a cluster of bulblets at the top of a scape 10 to 24 in. high. The leaves are grass-like, sheathing the stem above the fibrous bulb. Flowers in May and June in moist meadows, from N. B. to Mich. and southwards.

FIELD GARLIC (A. vineale) (European) is very similar to the last species; the leaves are linear and round in cross section, sheathing the stem below the middle. Flowering commonly in wet meadows during June; Mass. to Mo, and Va. 


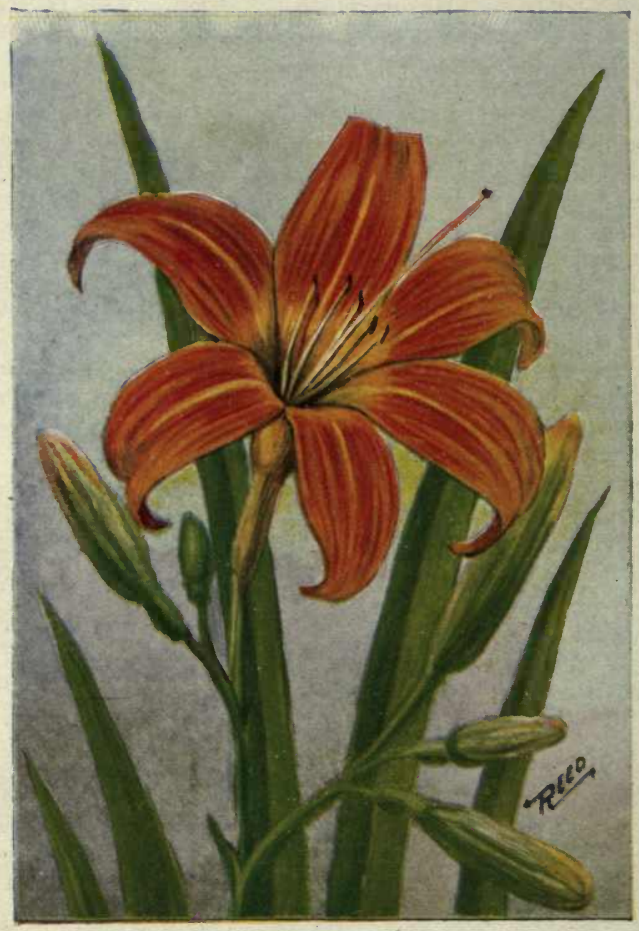

Day Lily. Hemerocallis fulva. 
DAY LILY (Hemerocallis fulva) (EUROPEAN) will, we think, prove a welcome addition to our flora. It is now locally abundant in R. I., Conn., and N. Y. It flourishes best near salt water and spreads rapidly by means of its running roots as well as by seed. The flower stalk is tall, 2 to 5 feet, and at its summit bears eight or nine buds which open one or two a day into large showy flowers.

The perianth is funnel-form, with six spreading orange limbs and six long stamens with large brown anthers. The blossoms appear in July and August, each remaining open for but a single day; this habit makes them very popular for vase flowers as the number of buds on each stalk insures fresh flowers every day for a week or more. The leaves are long and linear, similar to those of the Cat-tail, appearing from a fleshy perennial rootstalk at the base of the tall flower scape.

In the absence of any odor, the beautiful flower cup serves to attract the bees that are necessary for the setting of its seed.

Another species the YELLOW DAY LILY ( $H$. Flava) has also escaped from cultivation, but is not nearly as common as the above. The flowers are bright yellow and the leaves a lighter shade of green; the blossoms are also fragrant.

WILD HYACINTH! EASTERN CAMASS (Camassia esculenta) has small blue flowers in a simple raceme at the top of a scape from 6 to 24 inches high; the flowers appear on short pedicels and are bracted, the bracts being longer than the pedicels.

The six divisions of the perianth are wide spread; both the stamens and the style are extremely slender. The scape and the linear, keeled leaves botn rise from a coated bulb. This species is found growing in rich ground from $\mathrm{Pa}$. to Minn. and southwards. 


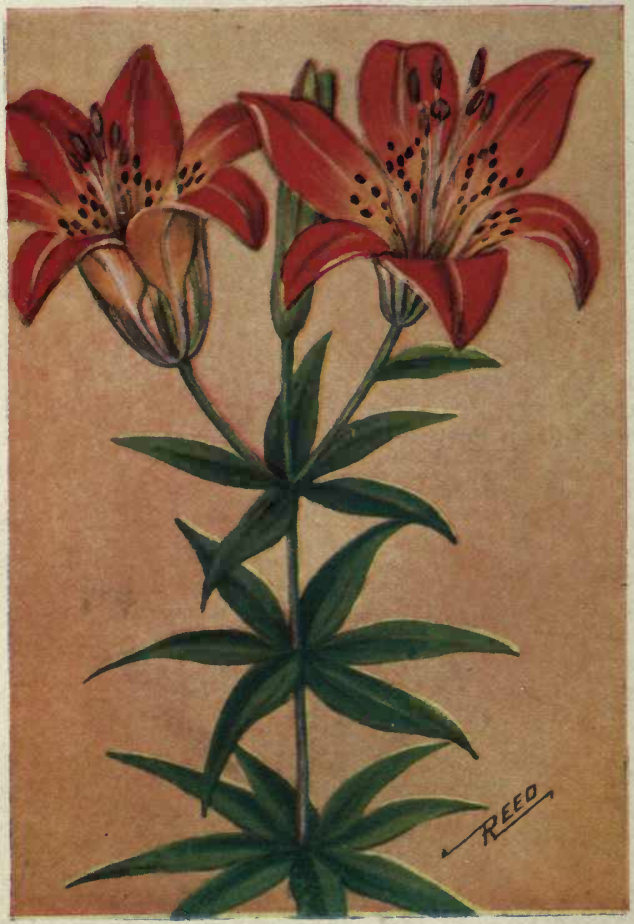

RED Wood Lily.

Lilium philadelphicum. 


\section{LILIES; Genus (Lilium).}

All the members of this genus are among our most beautiful flowers. In our range it includes eight species, of which seven are natives. The two species of Red Lily can readily be recognized because their perianth, or flower funnel, always opens upwards; the divisions of these perianths at their bases are very slender and stem-like in contrast with the following species whose divisions are united in a tube at the base. Its name is rather misleading for, while it is sometimes found in woods, they will be found blooming most profusely in sandy or brush covered land. One of the prettiest sights of which I know may be seen during the flowering season on the eastern end of the island of Martha's Vineyard on the cliffs known as Gay Head; as a rule each stalk there bears but a single flower at its summit. This also is true of the Southern Red Lily that is abundant on some of the sandy pine barrens of the southern states.

WOOD LILY; WILD ORANGE-RED LILY (Lilium philadelphicum) has a leafy stem 1 to 3 feet high, at its summit bearing one to four erect (not pendulous) flowers; the divisions of the perianth are deep orange-red, lightening in color at the stem-like bases and profusely spotted with dark brown; the outside of the perianth is dull whitish-green. The leaves are lanceolate, sharply pointed at each end and whorled about the stem in groups of from three to seven. Blooms in July and August in sandy soil from N. E. to Mich. and southwards.

SOUTHERN RED LILY (L. Catesbaei) has a single bright scarlet, bell-shaped, upright blossom, spotted within with purple and yellow. The leaves are narrow and scattered along the stalk. Found from N. C. to Mo. and southwards. 


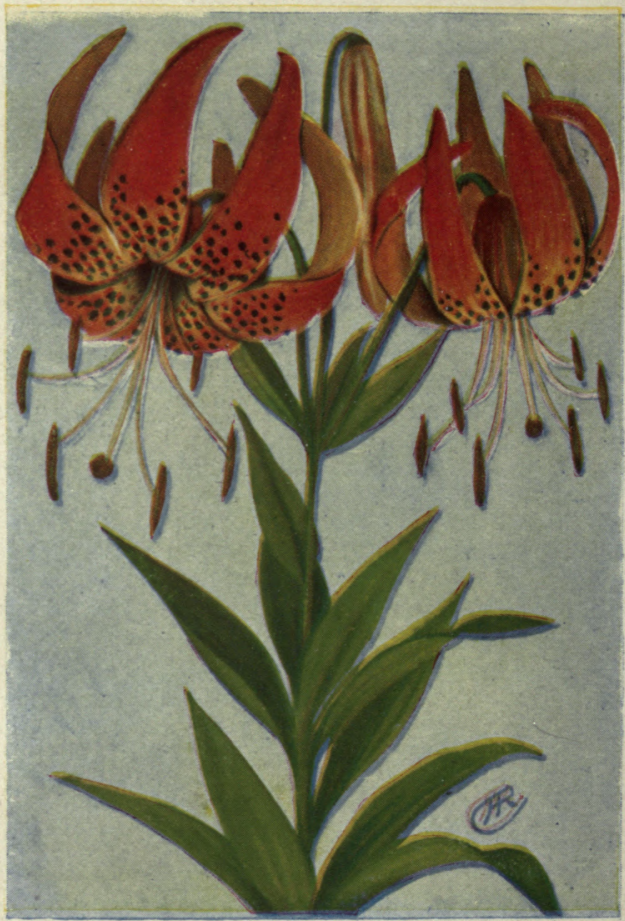

Turk's-cap Lily.

Lilium superbum. 
TURK'S-CAP LILY (Lilium superbum) is a most beautiful flower; it is very appropriately specifically called superbum. It is prolific in bloom almost beyond belief. One has to see the tall, stately, leafy stalk, surrounded by a drooping cluster containing from thirty to forty brilliant orange flowers, in order to realize the impressiveness of this flower at its best. The bright sepals are always reflexed, sometimes so much so that they remind one of a coiled spring. These lilies apparently know their own beauty for, be the surrounding foliage high or low, they will rear their flowering heads above it. They are cross-fertilized chiefly by bees and some of the larger butterfiies. One has but to touch the large pendant anthers to get a practical demonstration of how the pollen is attached to the body of a bee and carried to another flower, there to be deposited on the sticky stigma of the mature style. Naturally a species so prolific of flower and so capable of being cross-fertilized by foreign agency is in little danger of having its numbers lessened. In fact, wherever it gets a foothold it spreads with great rapidity; a habit that I am sure is regretted by none who admire this beautiful lily, and these number all who have ever had the opportunity to see it.

The flowers, nodding at the top of a stem ranging from 2 to 7 feet in height, have a six parted perianth, orange-red, thickly spotted with purplish brown; the six stamens have large, long brown anthers extending far beyond the reflexed sepals. The lanceolate leaves are crowded along the upper stem and whorled about its lower portion. Blooms abundantly in rich soil, during July and August, from N. B. to Minn. and southwards.

Lilium carolinianum is a quite similar species with broader leaves and only one to three flowers. Found on the borders of mountain woods from Va. southwards. 


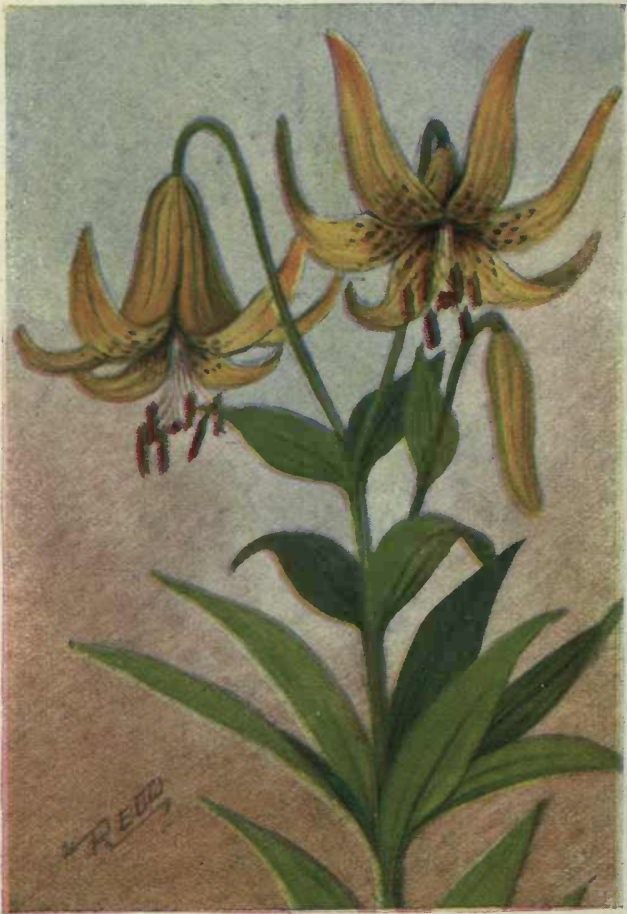

Meadow Lily.

Lilium canadense. 
FIELD, WILD, MEADOW, YELLOW or CANADA LILY (Lilium canadense) is one of the most abundant of the genus. Its graceful, bell-like heads nod in profusion in all suitable localities soon after it gains a foothold. Imagine a rich meadow, surrounded by deep green woods and covered with thousands of these lilies, their heads hanging and nodding invitingly and seeming fairly to tinkle in the bright sunlight. They are great favorites with country children, by whom they are often called "Fairy Caps" or "Witch-caps". They are also great favorites with all the larger bees and butterflies. On the whole, this flower may be regarded as more graceful in form than is the Turk's-cap, but it cannot compare with the latter flower for beauty of coloring. The regular whorled leaves and graceful bending penduncles supporting the hanging "bells" make a conventional design that often appeals to the artistic eye.

The flowers are in terminal clusters of one to twelve blossoms, nodding on long peduncles from the summit of a tall leafy stem; yellowish-brown outside and yellow or orange within, spotted with brown; sepals spreading and slightly reflexed, but not to any such degree as those of the Turks-cap. The leaves are lanceolate, arranged about the stem at intervals in whorls of three to eight. Flowers during June and July in moist meadows, from Quebec to Minn. and southwards to Ga. and Mo.

GRAY'S LILY (L. Grayi) has one or two deep orange-red flowers in a horizontal position; thickly spotted within; sepals spreading but little and uniting in a larger base than the preceding. Leaves in whorls of three to eight. Found in mountains from Va. to N. C.

TIGER LILY (L. tigrinum) (CHINESE) is a magnificent species with larger and brighter flowers than the Turk's-cap. Leaves 7-nerved instead of three. An escape from gardens. 


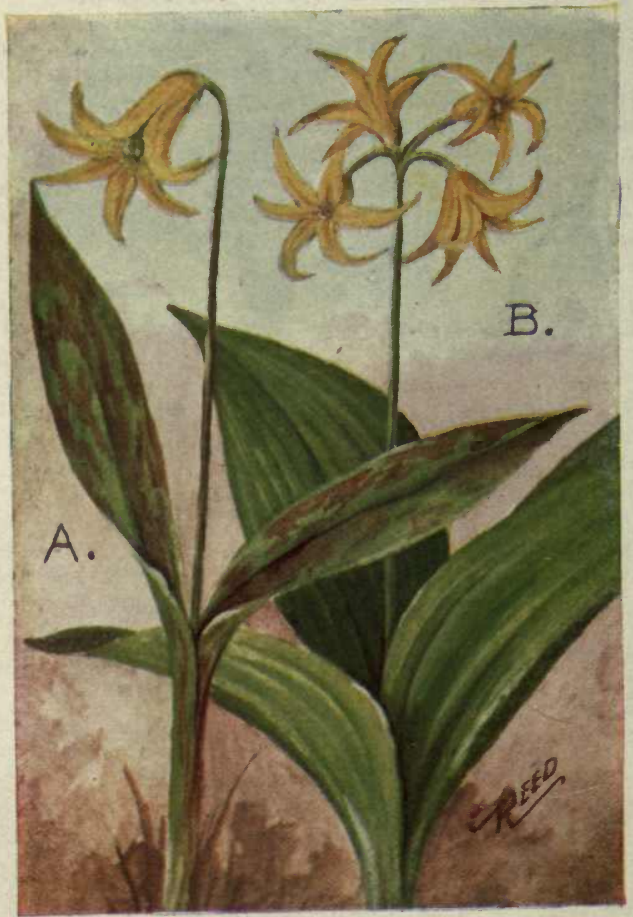

A. Yellow Adder's-tongue. Erythronium americanum.

B. Clintonia.

Clintonia borealis. 
DOG-TOOTH VIOLET; YELLOW ADDER'S TONGUE (Erythronium americanum). These flowers are familiar and welcome ones to all who wander beside woodland brooks in the Spring. The name "Violet" is of course a misnomer. It is often locally known at the "Trout Lily" or the "Fawn Lily," both of which names are far more appropriate than those given it generally.

The single flower grows at the top of a scape from 5 to $10 \mathrm{in.} \mathrm{high;} \mathrm{it} \mathrm{is} \mathrm{6-parted.} \mathrm{with} \mathrm{a} \mathrm{lily-like}$ perianth, the sepals being dull yellowish, spotted near the bases with brownish. Two elliptical-lanceclate leaves clasp the scape at its base, near the scaly bulb; they are pale green, mottled with purple and white. This species blooms in April and May in moist woods or swamps, from N. B. to Minn. and southwards.

WHITE ADDER'S TONGUE (E. albidum) is similar in size and form but the flower that nods at the top of the scape is either white or pale violet. The two leaves are less distinctly, or not at all, spotted. This is found in the same range as the last.

E. mesochoreum has narrower leaves and pale violet flowers. Prairies of Ia. and Mo.

E. propullans has small pointed leaves and bright rose-colored flowers. Found in Minn. and Ont.

CLINTONIA (Clintonia borealis) is named for and dedicated to a former N. Y. statesman, DeWitt Clinton. It is a beautiful species, its leaves resembling those of the Lily-of-the-Valley. The three to six pendulous, bell-shaped flowers are cream-colored within and greenish outside. Three large, oblong, pointed leaves clasp the flower scape at its base. The plant is about 6 to $16 \mathrm{in}$. high; it flowers during June in damp woods from Labrador to Man. and southwards.

C. umbellata has many smaller white flowers, spotted with purple. Mountains, N. Y. to Ga. 


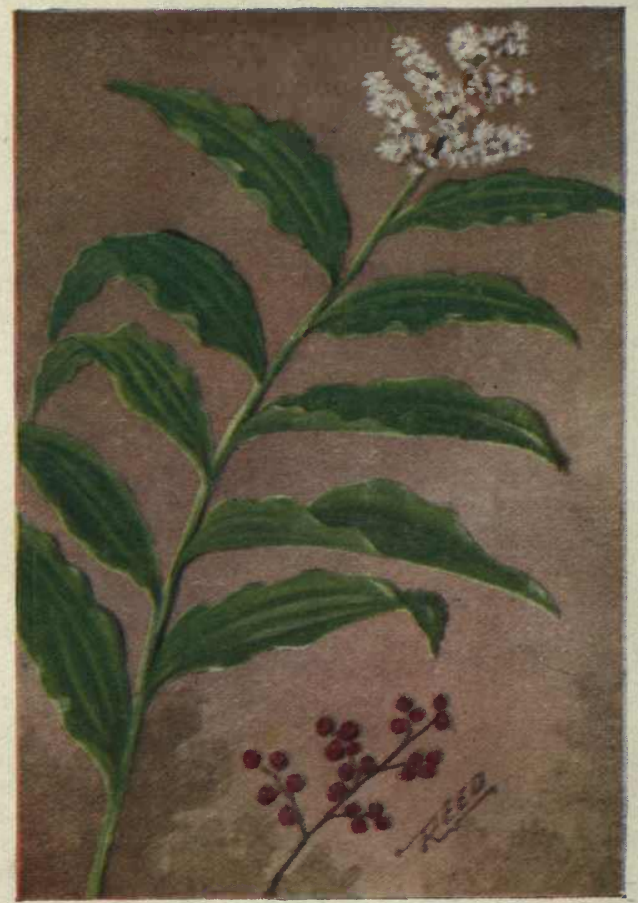

False Spikenard.

Smilacina racemosa. 
WILD SPIKENARD (Smilacina racemosa) is quite an imposing plant, with its long, curving, zigzag stem, its many light green deeply ribbed leaves and its feathery terminal flower clusters.

The white flowers are tiny but perfect, with a 6parted perianth, six slender stamens and a short, thick style. The stem is rather angular and attains a length of from 1 to 3 feet; alternating along it are the large, oval, sharply pointed leaves, with parallel ribs and wavy edge. The perennial rootstalk is thick and fleshy. Spikenard is quite abundant in most rich, uncleared ground, flowering in May and June, from Me. to Minn. southwards.

FALSE SOLOMON'S SEAL (Smilacina stellata) bears some resemblance to the last species, but the flowers are much larger and few in number, usually only six or eight terminating the zigzag stem. The leaves are broader at the bases and slightly clasp the stem, whereas those of the last species have very short stems. It grows commonly, but not as much so as the last, on moist banks and in meadows, from Me. to Minn. and southwards.

\section{ASPARAGUS (Asparagus officinalis) (EURO- PEAN).}

This is the common garden Asparagus that is sold in markets throughout the land. Few would think of it as belonging to the beautiful lily family but such is the case. Each scaly appendage on the vegetable, throws off a branch which divides and sub-divides into very numerous little branchlets, giving the plant an exceedingly beautiful and decorative appearance. The tiny yellow flowers appear in the axils of these branchlets during June. Later, bright red berries will be suspended on pedicels in place of the flowers. Asparagus is a common escape from gardens and may be met with anywhere. 


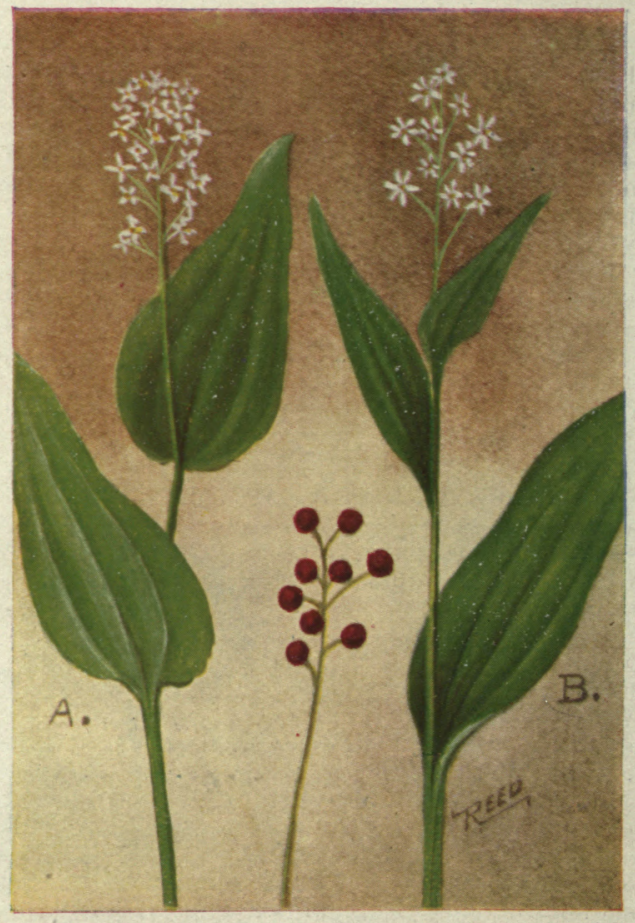

A. Canada Mayflower.

Maianthemum canadense.

B. False Solomon's Seal.

Smilacina trifolia. 
THREE-LEAVED .FALSE SOLOMON'S .SEAL (Smilacina trifolia) is the smallest member of the genus Smilacina. It is found rather commonly in bogs and wet woods. It is, however, not nearly as abundant as the next very similar species. The stem is straight and slender, from 2 to 6 in. high. It usually has three leaves, but sometimes two or even four; they are shining green, oblong-pointed and sheathing at the base, arranged at regular intervals along the stem. The flowers are white, few in number, on short peduncles in an open raceme at the summit of the stem. It is found from Labrador to Manitoba and southwards to N. J. and Mo., flowering during May and June.

CANADA MAYFLOWER; FALSE LILY-OF-THEVALLEY (Maianthemum canadense) is a very abundant woodland plant. It usually grows in colonies, thousands of them sometimes carpeting pine woods with their dark green glossy leaves. At a casual glance this species very closely resembles the last, but the distinction is very marked and as follows: The two, or three, broad, ovate-lanceolate, shiny green leaves are rather heart-shaped at the base, seated on the stem or very nearly so. The flower perianth has only four divisions whereas that of the last species has six. After the flowering season both of these plants have berries; at first a creamy white, spotted with brown, and later turning to a dull ruby-red.

It is unfortunate, and often confusing, that flowers should receive the common names that they do. Neither of these species in the least resembles the true Solomon's Seal and the only respect in which the False Lily-of-the-Valley resembles the real is that it usually has two leaves. This last species has the same range as the preceding. 


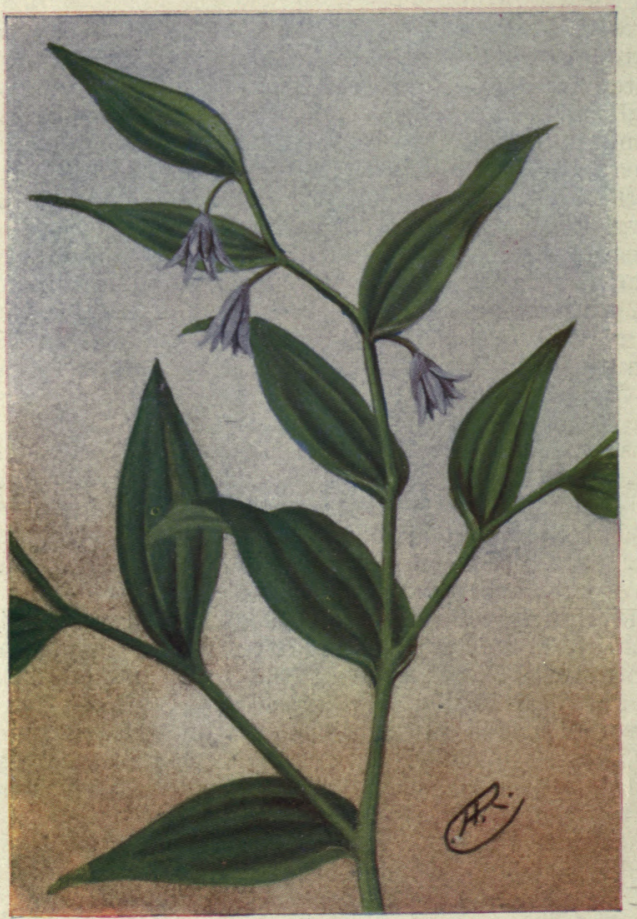

Purple Twisted-stalk.

Streptopus roseus. 
PURPLE TWISTED-STALK (Streptopus roseus) has, as would be judged from its name, a very angular or twisted stem. At each angle or joint, appears an ovate-lanceolate, cordately-ribbed, shining green leaf, seated on the stem; those of this species are bright green on both sides. From the axils of the terminal leaves appear small flowers on slender thread-like peduncles; these flowers are sometimes single or, again, in pairs; they have a bell-shaped base and the perianth is divided into six lanceolate, spreading dull purple sepals. The stem, which is rather sparingly bristly-hairy, reaches heights of 1 to $2 \frac{1}{2}$ feet. This rosy species blooms in May and June in cold moist woods from Newfoundland to Manitoba and southwards to the Gulf of Mexico.

COMMON TWISTED-STALK (Streptopus amplexifolius) is similar but has greenish-white flowers, the six sepals of which are very strongly reflexed. The plant is somewhat larger, the smooth stem being from 2 to 3 feet in length. The leaves are light, glossy green and have a whitish bloom on the under side; they clasp the stem with their bases. The perfect flowers are probably largely fertilized by the numerous small bee-like flies that are usually found about them. In the Fall, the plants are decorated with bright red berries in place of the blossoms. Birds are fond of these berries and, by scattering the seeds contained therein far and wide, often found new colonies of Twisted-stalks. The common species is found throughout northern United States and the southern half of Canada. 


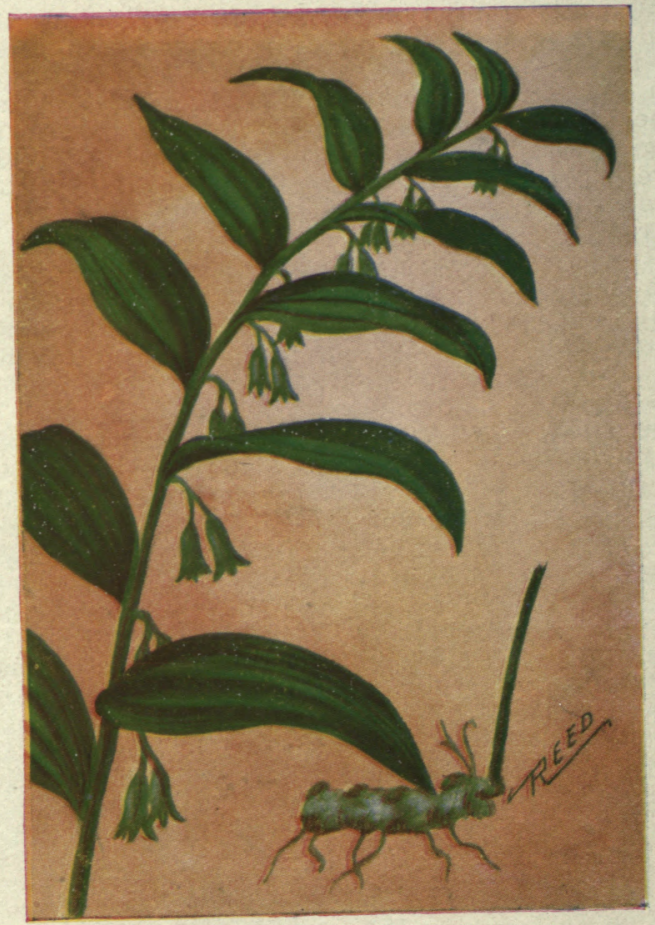

Solomon's Seal.

Polygonatum biflorum. 
SOLOMON'S SEAL (Polygonatum biflorum) has small greenish, bell-shaped flowers about one-half -inch in length, hanging in pairs on slender peduncles from the axils of the leaves. The stem is 1 to 2 feet in height. The oblong-lanceolate leaves alternate along, and are partly seated on, the stem; deep green above and glaucus or whitish below. Very common in woods from N. B. to Ont. and southwards, flowering from April to June.

GREAT SOLOMON'S SEAL (P. commutatum) is much larger, the flowers often measuring an inch in length, and from two to eight in each cluster from the axils of the leaves. The stem is stout and from 2 to 6 feet long. Found from western N. E. to Minn. and southwards.

These plants receive their names from the thick, fleshy and knotted rootstalks. They are perennials and each year throw up new stalks; after flowering these wither away and leave pronounced scars on the roots. These scars suggested the name of Solomon's Seal and the number of them will probably accurately denote the ages of the plants. Both the large and the small species grow in the same localities. They can readily be distinguished by comparison, for commutatum is always larger in all its parts; while it may be but a foot and a half tall it will be stouter and have comparatively larger flowers than its relative. Often it assumes truly gigantic size and may tower above a tall man's head.

Viewed from above the pendant blossoms are very inconspicuous, but if we look beneath the spreading leaves a row of flowers will be seen drooping from the axils of most of the leaves, in pairs on the species biflorum, but usually more on the larger species. Again the large variety is always smooth in all its parts while biflorum is usually downy or hairy. In the Fall the flowers are replaced by pairs of round bluish black berries. 


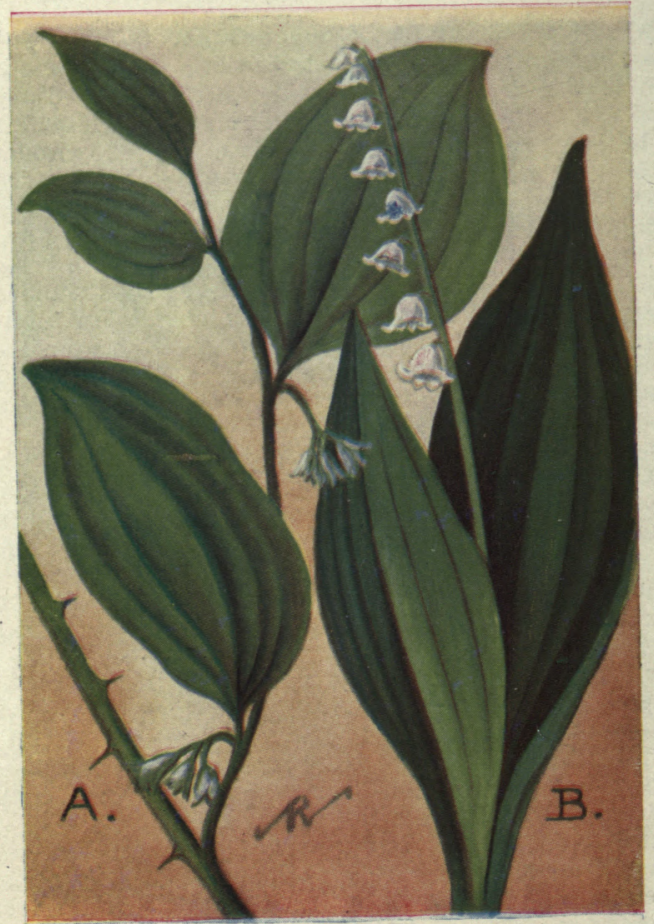
A. Green Brier.
Smilax rotundifolia.
B. Lily-of-the-VAlley.
Convallaria majalis. 
LILY-OF-THE-VALLEY (Convallaria majalis.) As a garden flower, this species is probably familiar to nearly everyone. While, as a native, it is only found in some of the southeastern mountain ranges, it is sometimes found in the North as an escape from cultivation. The flower we usually see in florists or in gardens is the European species but it appears to be identical with our native southern one. It is a delicately beautiful species, very rich in fragrance and very hardy; its popularity is shown by the frequency with which it appears in both poetry and prose. The bell-shaped, white flowers, with six short, re-curved lobes, grow in a one-sided raceme at the top of a scape, the base of which is sheathed by the two large, broad, oblong-pointed, parallel-veined leaves. It flowers in May and June in mountains from Va. to S. C.

COMMON GREEN BRIER (Smilax rotundifolia) is a woody climbing vine with scattered sharp prickles; it.climbs by means of pairs of tendrils from the axils of the leaves. Leaves alternating along the stem; round-ovate, sharply pointed at the tip and somewhat heart-shaped at the base. Flowers, few on slender peduncles from the angles of the leaves; perianth bell-shaped, with six short, spreading lobes, pale greenish in color. Common in moist thickets from N. S. to Minn, and southwards, flowering in May and June.

CARRION FLOWER (Smilax herbacea) has a herbaceous stem without prickles. The flowers are small, light green, carrion-scented, in a many flowered umbel on a long petiole from the angle of a leaf. Leaves heart-shaped and parallel-nerved. Found in the same range and flowers at the same time as the last. The genus smilax consists of many widely distributed species, usually having blue-black berries in the Fall. 


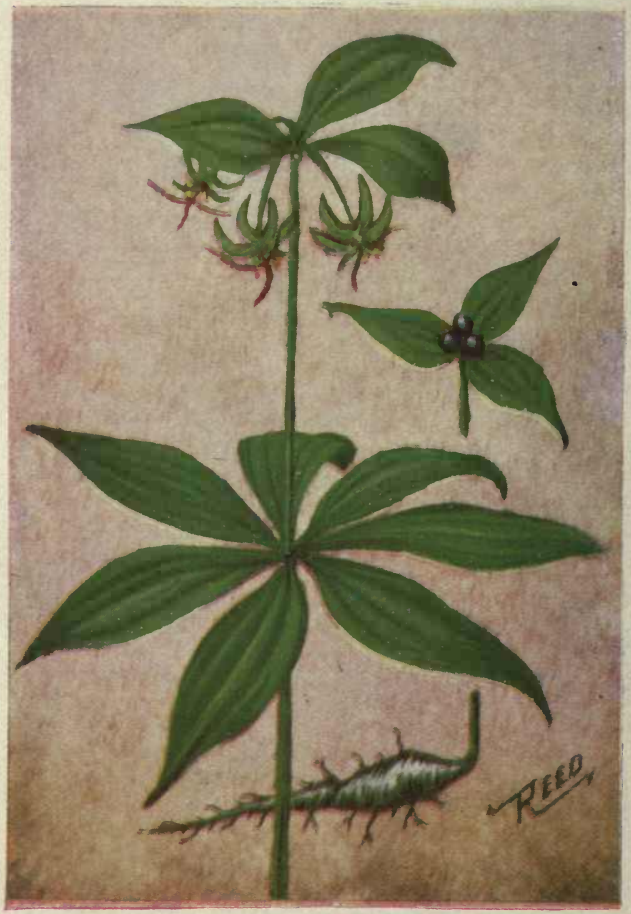

Indian CUCUMBer-Root. Medeola virginiana. 
INDIAN CUCUMBER-ROOT (Medeola virginiana) is a common woodland plant, but the flowers are so inconspicuous that they are often overlooked; in fact they are often nodding below the upper leaves so as to be invisible. The stem is tall and slender, ranging from 1 to 3 feet in height; it rises from a thick horizontal rootstalk, having a taste similar to that of the cucumber. A whorl of from five to nine ovatelanceolate, pointed leaves is located midway on the stem; at the top, three smaller but similarly shaped leaves radiate. Above these, or it may be below, because of the curving pedicels, are three flowers. They are pale greenish-yellow; the three sepals and three petals composing the perianth are very much reflexed or curled; they have six stamens each, and one style dividing into three purplish-brown, recurved stigmas.

It is said that the Indians formerly used the roots for focd; at the present time they are used for various medicinal preparations. Cucumber-root is found from N. B. to Manitoba and southwards to the Gulf, flowering in rich woods during May and June.

COLIC-ROOT; STAR GRASS (Aletris farinosa) is a tall, wand-like plant, striking in appearance even though not beautiful in flower. The scape is from 2 to 3 feet high, terminated with a small spike-like raceme of white, tubular flowers. The perianth is 6 lobed, very granular and roughened on the outside by thickly set points. It is this granular appearance, as though the flower had been sprinkled with white meal, that gives it its generic name. meaning "a female slave who grinds corn". The leaves are thin, flat and lanceolate, radiating from the rootstalk at the base of the flower scape. It is commonly found from Me. to Minn. and southwards, flowering in July and August. 


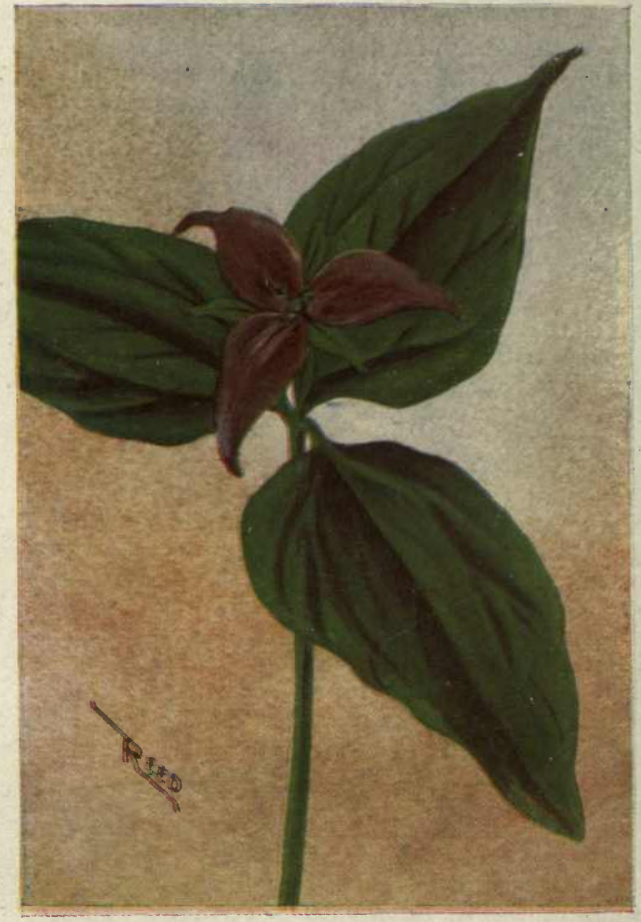

Purple Trillium; Wake Robin. Trillium erectum. 


\section{Genus (Trillium).}

Trilliums derive their generic name from the fact that all their parts are arranged in threes; three leaves, three petals, three sepals and a three-parted stigma. The common name of Wake Robin was probably early given because these flowers appear at an early date. As a matter of fact they do not bloom until weeks after the Robins have returned to the Northern States. All the purple trilliums have an unpleasant odor resembling that of putrid meat; as they are largely dependent for fertilization upon certain carrion flies, it is very probable that their peculiar color is for the purpose of an added lure for these insects. The Sessile Flowered Trillium has the parts of the stigma so recurved that they are very close. to the anthers and it is very probable that self-fertilization takes place. After the flowering season an oval reddish berry is seen rising from, or seated among, the three green leaves.

PURPLE TRILLIUM; BIRTHROOT; ILL-SCENTED WAKE ROBIN (Trillium erectum) has three purplish-brown petals (sometimes these are pink or even white in color) and three sepals; six stamens exceeding in length the stout spreading stigma. Flower solitary, raising on a short pedicel above the whorl of broad, ovate, pointed and short petioled leaves. This trillium ranges in height from 6 to 15 inches. It flowers in April and May, in rich woods from Quebec to Ont. and southwards.

STEMLESS PURPLE TRILLIUM (Trillium sessile) is very similar, but the flower is seated directly among the leaves with no stem, and the petals do not spread as much. It is found from $\mathrm{Pa}$. to Minn. and southwards.

Trillium viride has both the leaves and flowers sessile. The petals of this species are greenish and narrow. Found from Kas. and Mo. southwards. 


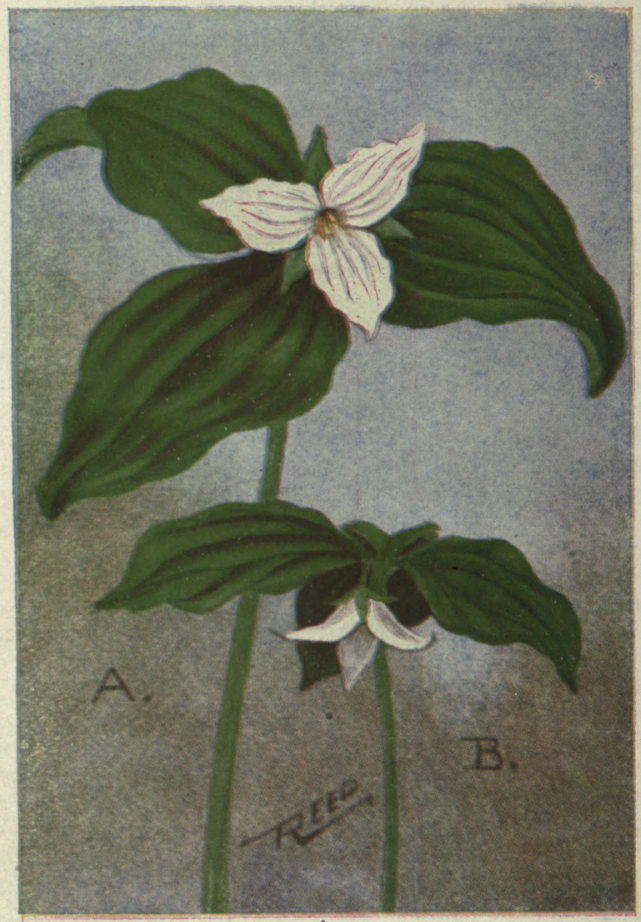

A. Large-flowered Trillium. Trillium grandiflorum. B. Nodding Trillum. Trillium cernuum. 


\section{Wild Flowers East of the Rockies}

LARGE-FLOWERED TRILLIUM (Trillium grandiflorum) is the largest of the genus in all respects and is one of the best known and most common species. It can be looked for with expectation of finding in any damp, rich woods during May or June. Should a brook run through the woods, you will be almost sure of finding this or some other trillium growing at some point along the banks. ( Usually they grow in colonies and it is an exception when one finds a single plant without others being in sight. The stem of this species is from 10 to 18 inches in height; the waxy white petals are from $1 \frac{1 / 2}{2}$ to 2 in. in length; as they grow older the color changes to a delicate pink and they curve gracefully backwards.

The flower is on a short pedicel above the whorl of broad,ovate-pointed and shortly petioled leaves; the latter are light green with three prominent, parallel ribs. This species is found from Vt. to Minn. and southwards, to N. C. and Mo.

NODDING TRILLIUM (T. Cernuum) is quite similar to, but smaller than the last species. Its blossom is either white or pink and is on a curved pedicel that often bends so as to place the flower beneath the whorl of leaves; the edges of the petals are quite wavy. This demure, bashful little trillium is found from Newfoundland and Man. South to Pa. and Mich.

Trillium declinatum is similar to the Nodding Trillium but the flowers are on a longer horizontal pedicel. It is found from Mich. and Minn. south to Mo.

DWARF WHITE or SNOW TRILLIUM, (T. nivale) is a diminutive species with white flowers. standing only 2 to $5 \mathrm{in}$. high. The bell-shaped flower is erect; both the petals and the leaves have rounded ends. Pa. to Minn. and south to Tenn. and Mo. 


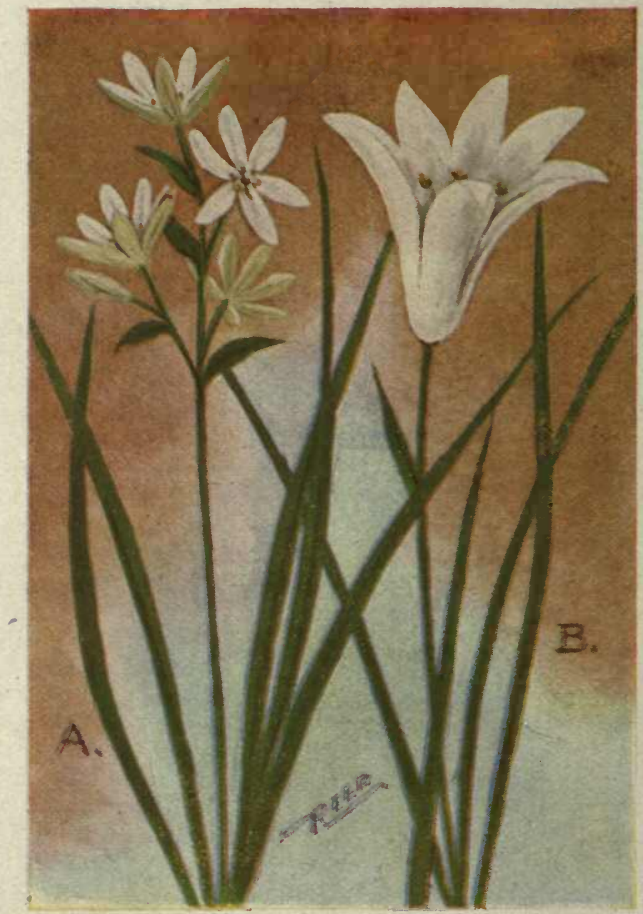

A. Star-of-Bethlehem.

Ornithogalum umbellatum.

B. Atamasco Lily.

Zephyranthes Atamasco. 
STAR-OF-BETHLEHEM (Ornithogalum umbellutum) (EUROPEAN). This dainty plant is sometimes met with near some farm house, from the garden of which it may have escaped years before. It is quite hardy and will increase rapidly if allowed a fair chance:

It receives its name from the star-like appearance of the white flowers as they peer up through the meadow grass. The original home of this flower is in Italy.

The scape, rising from a coated bulb, is from 6 to 12 in. high; at the top is a loose, terminal cluster of from four to eight blossoms. The perianth is divided into six waxy-white sepals, rather greenish on the outside, and with three to seven green nerves; six stamens and a three-sided stigma; flower pedicels slender and bracted at their junction with the scape. The leaves are long, linear and channeled. It may be found as an escape, from Me. to Va.

\section{AMARYLLIS FAMILY (Amaryllidaceae).}

A family of bulbous and scape-bearing herbs with flat, grass-like leaves and regular six-parted flowers.

ATAMASCO LILY (Zephyranthes Atamasco) is an exceedingly beautiful species with pure, waxy-white flowers, only one to a plant, erect at the summit of a scape from 6 to 12 in. high. Perianth funnel-form, with six spreading lobes, a short pistil and six stamens with large yellow anthers. Leaves long, linear and channeled. Quite common in moist places or swamps, from Del, to Fla., flowering from April to July.

HYMENOCALLIS (Hymenocallis occidentalls) has large showy, fragrant, white flowers in an umbel-like head; perianth broad, funnel-form with a two-notched edge; 3 or 4 in. in length. Leaves long and strapshaped. In marshy places from Mo. and Ill. southeast to Ga. and Ala. 


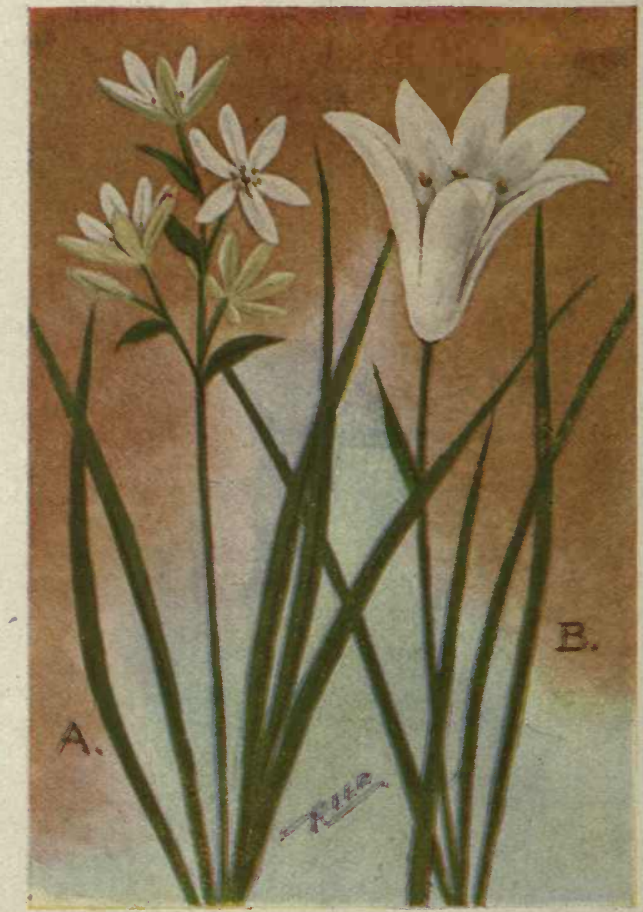

A. Star-of-Bethlehem.

Ornithogalum umbellatum.

B. Atamasco Lily.

Zephyranthes Atamasco. 
STAR-OF-BETHLEHEM (Ornithogalum umbellutum) (EUROPEAN). This dainty plant is sometimes met with near some farm house, from the garden of which it may have escaped years before. It is quite hardy and will increase rapidly if allowed a fair chance:

It receives its name from the star-like appearance of the white flowers as they peer up through the meadow grass. The original home of this flower is in Italy.

The scape, rising from a coated bulb, is from 6 to 12 in. high; at the top is a loose, terminal cluster of from four to eight blossoms. The perianth is divided into six waxy-white sepals, rather greenish on the outside, and with three to seven green nerves; six stamens and a three-sided stigma; flower pedicels slender and bracted at their junction with the scape. The leaves are long, linear and channeled. It may be found as an escape, from Me. to Va.

\section{AMARYLLIS FAMILY (Amaryllidaceae).}

A family of bulbous and scape-bearing herbs with flat, grass-like leaves and regular six-parted flowers.

ATAMASCO LILY (Zephyranthes Atamasco) is an exceedingly beautiful species with pure, waxy-white flowers, only one to a plant, erect at the summit of a scape from 6 to 12 in. high. Perianth funnel-form, with six spreading lobes, a short pistil and six stamens with large yellow anthers. Leaves long, linear and channeled. Quite common in moist places or swamps, from Del. to Fla., flowering from April to July.

HYMENOCALLIS (Hymenocallis occidentalls) has large showy, fragrant, white flowers in an umbel-like head; perianth broad, funnel-form with a two-notched edge; 3 or 4 in. in length. Leaves long and strapshaped. In marshy places from Mo. and Ill. southeast to Ga. and Ala. 


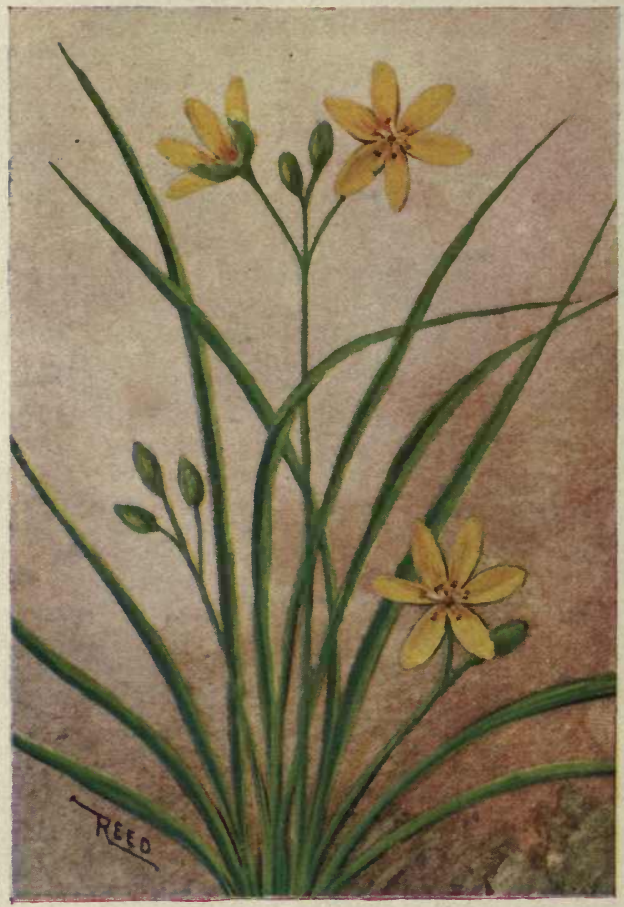

Yellow Star Grass.

Hypoxis hirsuta. 


\section{Wild Flowers East of the Rockies}

YELLOW STAR GRASS (Hypoxis hirsuta) is the most widely distributed of any of the members of the Amaryllis family. It is very appropriately named. From April until July and more sparingly until September we may see these bright shining golden stars peering at us from a background of green grass. So closely do the leaves of this little plant correspond to the grass leaves, among which they grow, that sharp scrutiny is required to distinguish them. Usually fields or open woods are chosen for their habitat, dry places in which we may also find quantities of Bluets or Innocence and common Cinquefoil. Although there are from four to eight buds to be found near the summit of the slender scape, but one, or at most two, of these open at a time. As they remain open for several days, a single plant may remain in bloom for two or three weeks. The blossoms are visited by several of the smaller bees for pollen; some of this is often unwittingly carried to the sticky stigma of the next flower visited and crossfertilization effected. The flowers, in withering, close up so that should a blossom not have been already fertilized, its own anthers will come in contact with its stigma.

The flowers are in a loose umbel at the top of a scape from 3 to 8 in. in height; perianth wide spread and divided into six shining, golden-yellow sepals, paler and slightly greenish on the outside; the six stamens tipped with large golden-orange anthers. The slender, narrow, grass-like leaves come from a small bulb together with the flower scape. This species is common from Me. to Manitoba and southwards to the Gulf of Mexico.

Cooperia Drummondii has a solitary white flower with six wide spread divisions and a long slender tube, from 2 to 4 in. long. Leaves grass-like. Found on prairies from Kans. to Texas. 


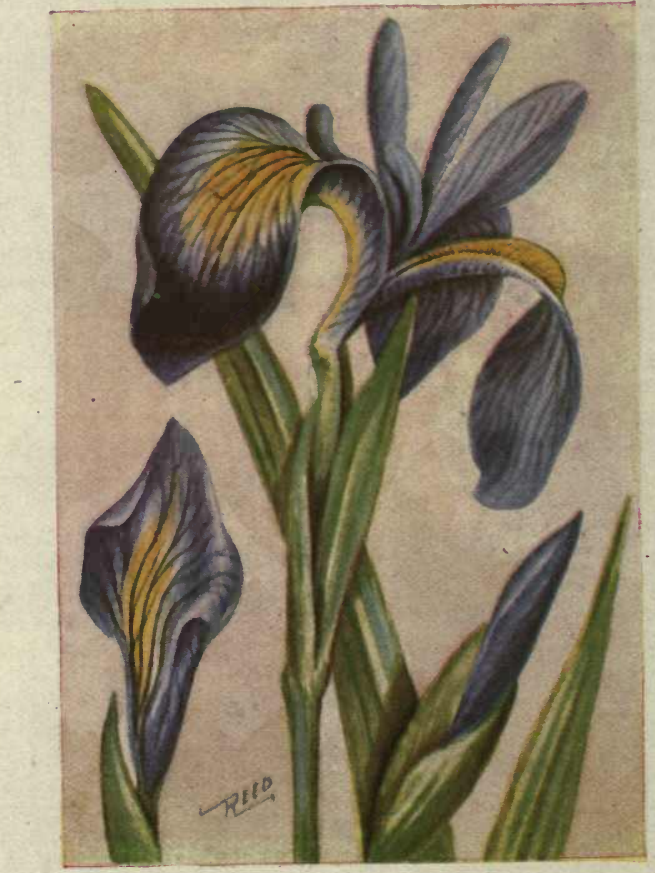

Blue Flag; Iris.

Iris versicolor. 


\section{IRIS FAMILY (Iridaceae).}

This family is composed of perennial herbs growing in moist places and having long linear or swordshaped leaves and large showy flowers. Iris is named from the Greek, meaning rainbow and it certainly is no misnomer as applied to the Blue Flag or Iris which is the most common of the genus. Small indeed is the pond-hole that somewhere around its edge does not have a little colony of the beautiful "Fleur-de-lis". The perpetuation of this species in healthy condition is insured because of the formation of the flower, which is such that self-pollenization is practically impossible. The stamens are directly under the strap-like divisions of the style and the stig$\mathrm{ma}$ is on the upper surface at the rolled-up tip. Bees are the most frequent visitors and the most valuable ones for the plants.

LARGER BLUE FLAG; BLUE IRIS; FLEUR-DELIS (Iris versicolor). Flower solitary, from a green spathe at the end of a long peduncle; sepals, neither bearded nor crested, but broad, violet and handsomely veined; petals erect, flat and spatulate. Leaves sword-shaped, glaucus-green, folded into a flat cluster at the base. Very common from Newfoundland to Manitoba and southwards, flowering from May to July.

SLENDER BLUE FLAG (Iris prismatica) is more slender in all its parts; narrow leaves, slender stem and very slender pedicels. Found in marshes near the coast from N. B, to Ga.

BLACKBERRY LILY (Belamcanda chinensis) CHINESE) has the sepals and petals of equal size and colored alike; a golden-orange, thickly speckled with brownish purple. Stem branching and with a loose cluster of six to twelve buds or blossoms. Fruit blackberry-like, studded with black seeds. An escape from gardens. 


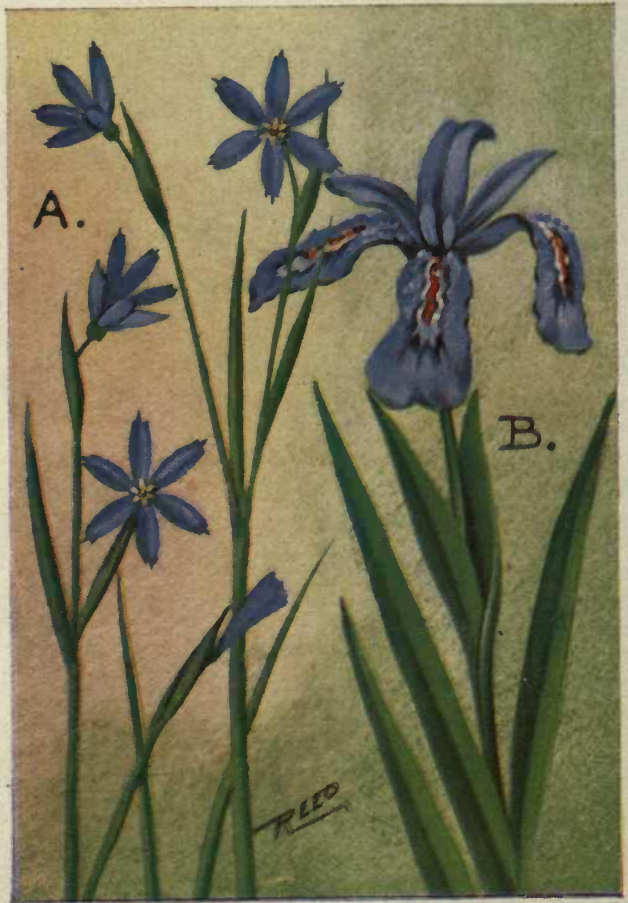

A. Blue-eyed Grass.

Sisyrinchium angustifolium.

B. Crested Dwarf Iris.

Iris cristata. 
CRESTED DWARF IRIS (Iris cristata). Flowers usually solitary, very delicate in form and of a light violet color; the sepals have a central crested rib of a bright orange color; the smaller petals are also crested. The tube is long and thread-like. Leaves lanceolate, about 5 to 7 in. long; those forming the spathe are ovate-lanceolate. This attractive little Iris is found on rich wooded hillsides and along streams, from Md. and Ind: southwards, flowering in April and May.

DWARF IRIS (I. Verna) has linear, grass-like leaves covered with a whitish bloom. Sepals not crested but rather downy on their yellowish base; color pale violet or even white. Found on rich wooded hillsides from Pa. southwards.

NORTHERN NEMASTYLIS (Nemastylis acuta) has a branching stem, at the end of which are one or two flowers growing on slender pedicels from a grasslike spathe. The six parts of the blue or purple perianth spread from 1 to 2 inches. It has long, linear leaves coming from the coated bulb. Found on prairies and barrens from $\mathrm{Ky}$. to Mo., southward.

BLUE-EYED GRASS (Sisyrinchium angustifolium), as one would suspect from the name, has grass-like leaves and flowers that make one think of bright little blue eyes as they peep out of the meadow grass in which you find them.

The Blue-eyed Grasses have recently been separated into thirteen species, differing chiefly in the comparative lengths of the flower spathes, or the lengths of the leaves as compared to the flower stem. If one wishes to know the exact specific name of the species he finds, we refer him to the new edition of Gray's Botany (7th Ed.) The six divisions of the flower are regular, violet, with a yellow or white starshaped center; each sepal is blunt, with a thorn-like tip. Common from N. B. to B. C. and southwards. 


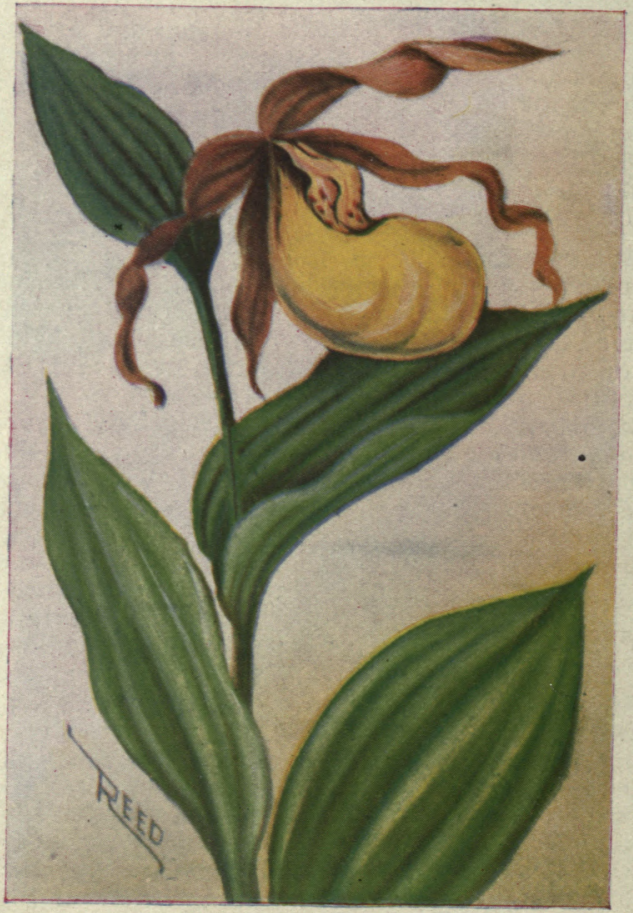

Yellow Lady's Slipper.

Cypripedium parviflorum. 


\section{Wild Flowers Eist of the Rockies}

\section{ORCHIS FAMILY (Orchidaceae).}

This is a large family composed of herbaceous perennials with tuberoid roots or corms. The perianth is composed of six divisions, the three outer being sepals (two of which are often united) and the three inner ones petals, the lower one of which, termed the lip, differs in form from the others.

YELLOW LADY'S SLIPPER (Cypripedium parviflorum) has usually one, but sometimes three flowers at the summit of a leafy stem 7 to $20 \mathrm{in}$. high. The inflated lip is bright yellow, slipper-shaped and with a rounded open orifice near the base. The two lateral petals are brownish; exceedingly twisted. The broad, bright green leaves are very prominently ribbed lengthwise, pointed and alternately sheathing the stem. This is one of the northerly species, being found along the northern border of the United States and southern Canada. It grows in colonies and flowers from May to July, in rich woods or bogs.

LARGE YELLOW LADY'S SLIPPER (c. p. pubescens) is a form of the last, averaging larger in all its parts. It is found in the same range.

\section{RAM'S HEAD LADY'S SLIPPER}

(Cypripedium arietinum) is not as handsome as the other members of this genus, but it is the most rare of the Lady's Slippers and, on that account, is very highly prized. The three sepals are separate, the upper one being ovate and pointed, while the lateral ones are lanceolate, brownish-purple and very similar to the lateral petals; the swollen lip is small, little more than half an inch in length; white, with crimson veinings. The three or four leaves are elliptical and nearly smooth. The stem is from 6 to 12 inches in height. This species is very locally distributed in swamps from Me. to Manitoba, southwards to Mass. and N. Y. 


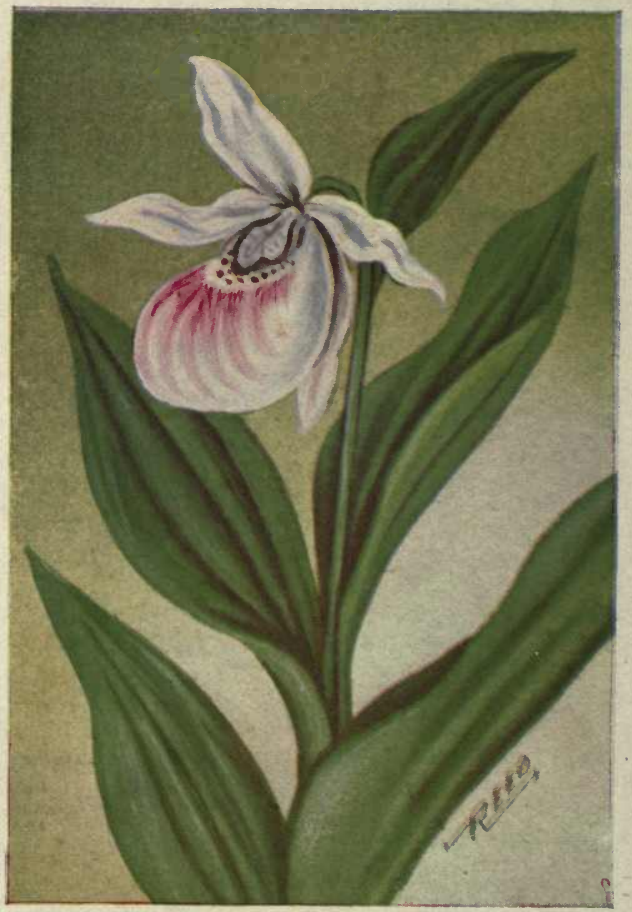

Showy Lady's Slipper.

Cypripedium hirsutum. 
SHOWY LADY'S SLIPPER

(Cypripedium hirsutum) is a magnificent orchid, usually regarded as the most beautiful of the genus. It is of imposing dimensions and has large fragrant flowers. The leaves are very large, closely crowded along the stem and very deeply ribbed, giving the plant, disregarding the flower, an appearance very much like the beautiful foliage of the common False Hellebore. While this species is not rare, it is quite locally distributed and it is always with a feeling of exultation that we discover a new colony.

The inflated flower lip is large and balloon-like, about 2 in. in length; white, with crimson-magenta blotches and streaks on the front edge; the sepals are round-ovate and the petals oblong, both pointed and both greenish-white in color. The leafy stem, that bears at its summit the solitary blossom, is from 1 to 2 feet in height. Found locally from Newfoundland to Minn. and southwards to Ga. and Mo. flowering in rich woods during June and July.

Cypripedium passerinum is a smaller species with a pale magenta lip, spotted with deep magenta at the base within; the upper sepal is yellowish and nearly round. The stem is covered with soft hairs; it is about eight inches in height. The elliptic-lanceolate leaves are sharply pointed. This species may be found in rich woods from Mich. and Ontario, westwards.

SMALL WHITE LADY'S SLIPPER (Cypripedium candidum). The flower of this species is of the same size and shape as that of the Yellow variety, but the lip is pure white outside and striped with purple inside at the base; the two lateral sepals and the two petals are ovate-lanceolate, greenish, spotted with brown. It is a single flowered species with numerous leaves. It is found in swamps from N. Y. and Minn. southwards. 


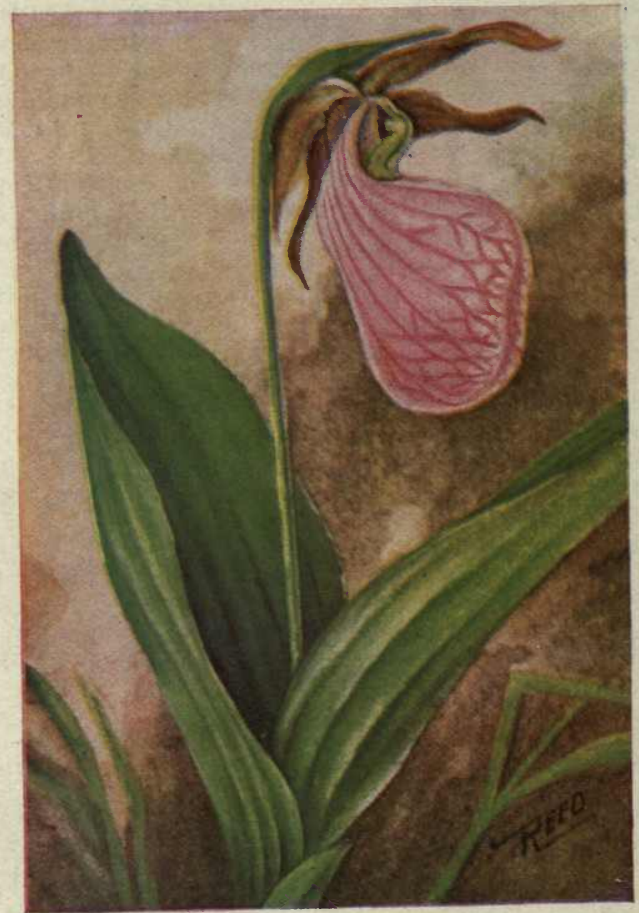

Moccasin Flower.

Cypripedium acaule. 


\section{Wild Flowers East of the Rockies}

\section{PINK LADY'S SLIPPER; MOCCASIN FLOWER}

(Cypripedium acaule) has solitary flowers surmounting a scape from 8 to 12 in. high; lip large, drooping, pink, with a slit in front, instead of a circular opening as in the others. It frequents dry woods and may be found from southern Canada, southwards.

This is the most common of the Lady's Slippers and too in my mind is not less beautiful than any of the others. I rather think that if it were as rare as the Ram's Head, it would be regarded and prized as one of the most beautiful and exquisite flowers that we have. Among all our plant families none are so exclusively adapted to fertilization by insects as those comprising the orchids. The flower of the present species is a very ingenious contrivance; it is fertilized by the common bumblebee. He knows there is plenty of food in the interior of the pink sac. The only chance for entrance is through the fissure in the front; it requires considerable pressure to force his burly frame through, but at length he succeeds and the aperture closes behind him. After eating his fill he takes the easiest way out, towards the base where he can see two spots of light. As he forces his way through the narrow passage he comes in contact with a sticky stigma, armed with in-curving hairs which remove any pollen he may have on his back; as he continues his struggle out he reaches an anther blocking the passage and waiting to clap its load of pollen on his back. Thus when he emerges he is fully charged with pollen to deposit on the stigma of the next flower visited. If you notice you will see that bees continue feeding on the same species of flowers and will pass by those of other species. This habit is Nature's protection against leaving the pollen of one plant at the door of another entirely different species, where it would do no good. 


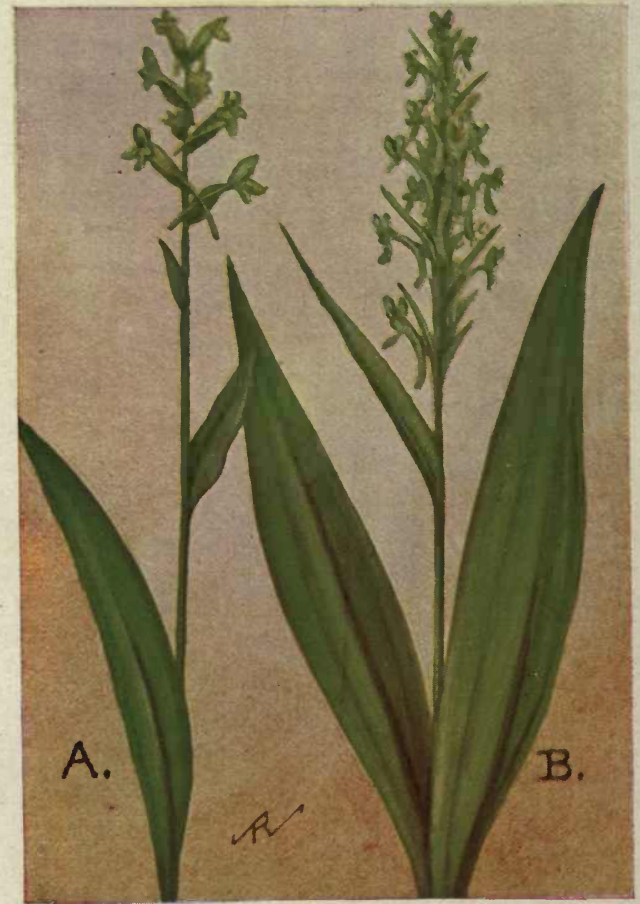

A. Green Wood Orchis.

Habenaria tridentata.

B. Green Fringed Orchis.

Habenaria virescens. 
GREEN WOOD ORCHIS (Habenaria clavellata) has from three to sixteen inconspicious greenish flowers in a loose spike at the top of a stem from 6 to $18 \mathrm{in.} \mathrm{high;} \mathrm{lip} \mathrm{oblong} \mathrm{and} \mathrm{with} \mathrm{three} \mathrm{teeth;}$ spur long, slender and curved upwards and to one side. One or two oblong-lanceolate leaves with obtuse tips, clasp the stem near the base while several small bracts alternate along it. Grows in bogs from Newfoundland to Minn. and southwards.

GREEN-FRINGED ORCHIS (Habenaria flava) is a common green orchis (formerly virescens). The lower leaves are oblong-lanceolate, while the upper ones are linear, diminishing in size and passing into the flower bracts. The flower lip is square-ended and toothed; spur slender and about the length of the flower. In the whole U. S. and southern Canada, we may find this species growing in bogs or wet places.

Habenaria bracteata is similar to flava, but the flower bracts are large, being from two to four times the length of the flowers; the spur is about half the length of the flower. The upper leaves are lanceolate and pointed; the lower ones are broader. The stem ranges in height from 6 to 20 inches. This species is also found in bogs, from N. S. to Alaska and south through the U. S..

Habenaria integra is similar in size and shape to clavellata but the flowers are a bright orange-yellow in color; the lip is ovate, rough on the edge; the spur is short, tiny and descending. It grows in wet pine barrens from N. J. and Tenn. south to Fla. and Tex., flowering in June.

Habenaria nivea is a southern species found along the coast from Del. to Fla. It is more slender than the preceding species. The leaves are narrow, and the numerous flowers are white, with narrow lips and petals; spur short, slender and ascending. 


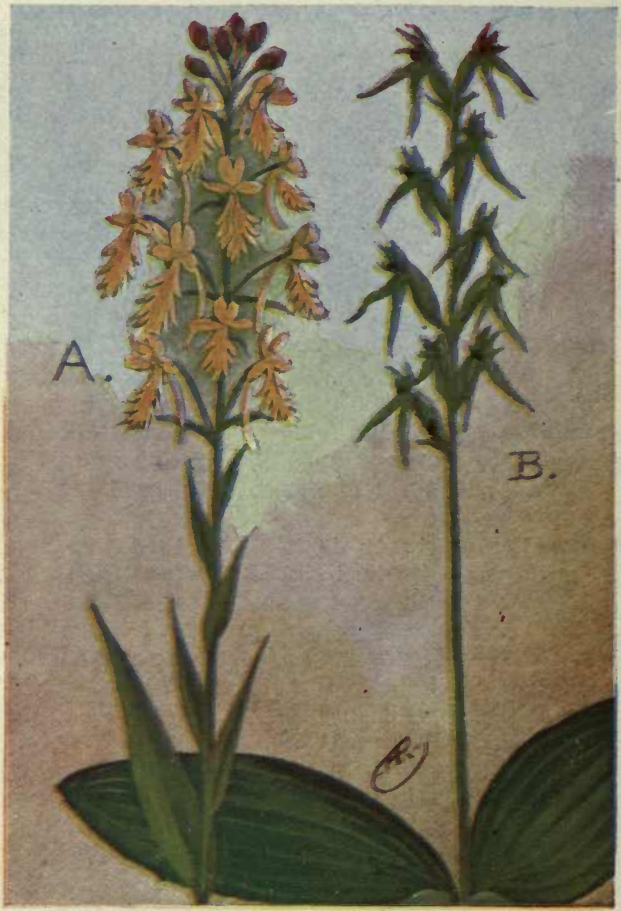

A. Yellow Fringed Orchis

Habenaria ciliaris.

B. HoOKer's Orchis.

Habenaria Hookeri. 
YELLOW-FRINGED ORCHIS (Habenaria ciliaris) is an attractive and rather common Orchis with a tall leafy stem from 12 to 24 in. high. It is always with a thrill of exultation that we, each year, first spy the golden yellow spikes in the deep recesses of a cold bog or swamp. The open blossoms have ex. quisitely fringed lips, while the buds on the upper part of the flower spike resemble little golden balls. The spike is very closely set with flowers having rounded petals, fringed lips and slender spurs about an inch in length. The leaves are lanceolate, gradualy diminishing in size as they approach the spike and passing into the flower bracts. Found from Me. to Mich. and southwards.

YELLOW CRESTED ORCHIS ( $H$. cristata) has orange-yellow flowers in a bracted raceme, the bracts being of about the same length as the flowers. The lip is ovate, copiously fringed; petals oblong, fringed at the top; spur short, not more than half an inch in length. Leaves narrowly lanceolate and growing smaller as they approach the flower spike. This Orchis flowers during July and August in peaty bogs, from N. J. to Mo. and southwards.

HOOKER'S ORCHIS (H. Hookeri) has a leafless scape from 6 to $12 \mathrm{in.} \mathrm{high,} \mathrm{at} \mathrm{the} \mathrm{base} \mathrm{of} \mathrm{which} \mathrm{are}$ two, broad, oval, shining, deep green leaves. The ten to twenty flowers, are yellowish green; lip lanceolate and sharply pointed, less than half an inch long; slender spur about one inch long. Flowers during June and July in woods from Me. to Minn. and south to N. C.

ROUND-LEAVED ORCHIS ( $H$. orbiculata) is similar to Hookeri; the lip is oblong, obtuse and about the same length as the spur. The two basal leaves are almost round. It is common in rich woods from Labrador to Alaska and southwards. 


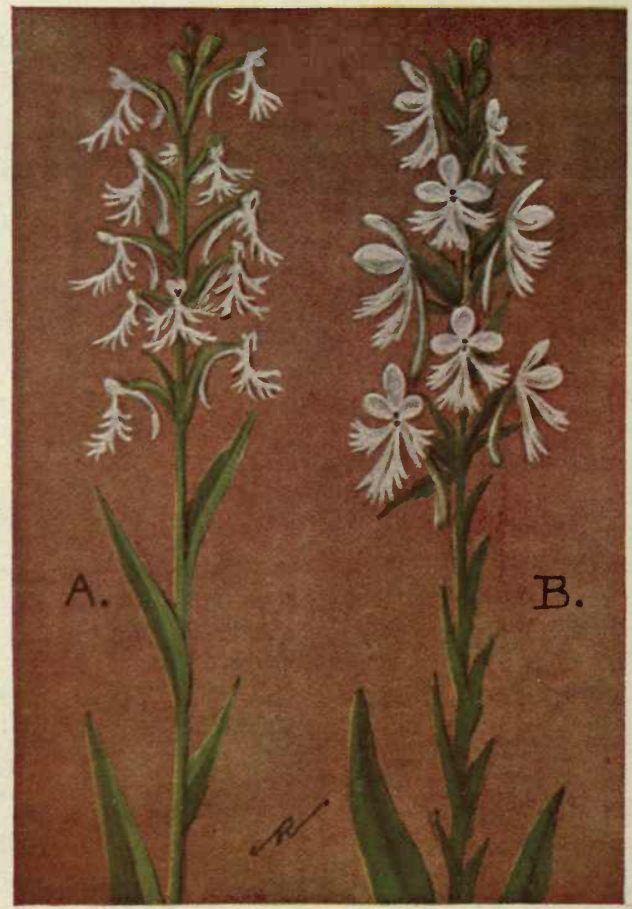

A. Ragged Fringed Orchis.
Habenaria lacera.

B. White Fringed Orchis.

Habenaria blephariglottis. 
RAGGED FRINGED ORCHIS (Habenaria lacera) does not attract our attention because of its beauty, for its flowers are rather inconspicuous in color. They are, however, remarkable for the peculiarly cut and slashed lip, it being divided apparently with no regard for method or symmetry. The greenish-white flowers are in a dense, many-flowered raceme at the summit of a leafy stem from 10 to 20 inches high. The leaves are oblong-lanceolate, diminishing in size to the flower bracts as they reach the raceme. This species is not uncommon in swamps from Newfoundland to Minn, and southwards.

\section{WHITE FRINGED ORCHIS (H. blephariglottis)} has a densely flowered raceme or spike similar to that of the Yellow Fringed species, but the flowers are pure white; the lip is not divided but is copiously fringed; lateral sepals rounded, upper ones elliptical and concave; spur nearly an inch long. Leaves lanceolate and gradually diminishing in size as they alternate to the top of the stem. In July and August you may find this species flowering, throughout the United States.

Habenaria leucophaea is also a white fringed Orchis. It is large, the stem varying from 1 to 3 feet in height. The flowers are also large, the spur averaging 1 1-2 inches in length; the lip is in three divisions, each of which is conspicuously fringed; the lateral and upper sepals are nearly round and quite strongly concaved. The lanceolate leaves are large at the bottom of the stem, but are reduced in size to the flower bracts as they reach the spike. This will be found in wet meadows and swamps from N. S. to Minn. and southwards, chiefly west of the Alleghanies, to the Gulf of Mexico, flowering in June and July. 


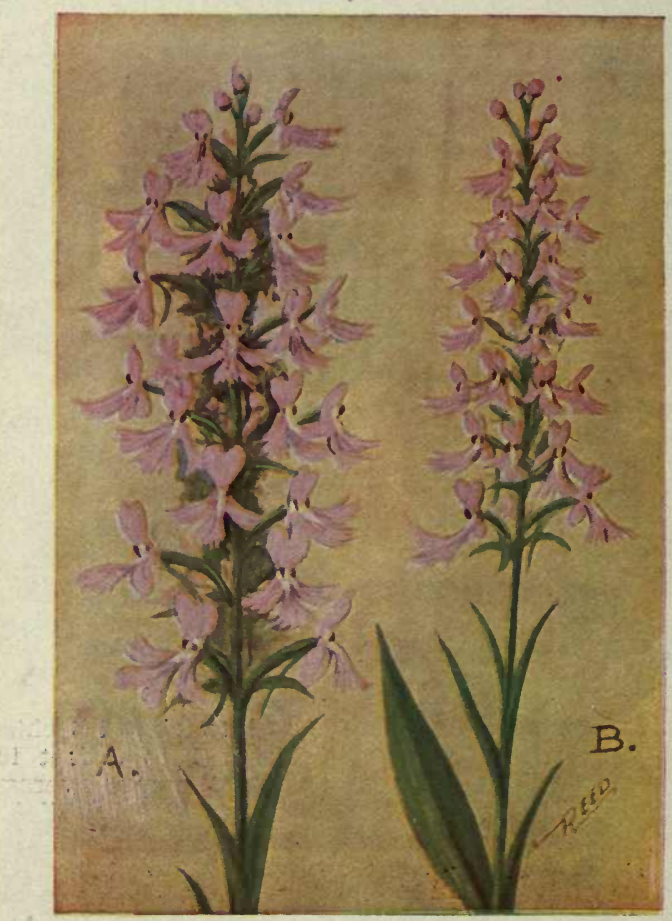

A. Purple Fringed Orchis. Habenaria fimbriata.

B. Small Purple Fringed Orchis. Habenaria peramoena. 


\section{Wild Flowers East of the Rockies}

SMALL PURPLE FRINGED ORCHIS (Habenaria psycodes) has pale purplish flowers in a dense cylindrical spike terminating a leafy stem, about 1 or 11 -2 feet tall. The spreading flower-tip is 3-parted and fringed; sepals rounded, petals spatulate and slightly toothed. The leaves are lanceolate and, like those of the fringed orchids, grow smaller as they approach the top of the stem. Flowers in July and August in wet meadows or swamps, from Newfoundland to Manitoba and southwards.

LARGE PURPLE FRINGED ORCHIS (H. fimbriata) is the largest and perhaps the most beautiful of the genus. The pale purple flowers are nearly twice as large as those of the last species; the lip is more deeply fringed. The densely flowered spike is about two inches in diameter and often is twelve inches long. The leafy stem attains heights of from 1 to 5 feet. It is a magnificent plant, the sight of which is well worth the inconveniences necessary to visit its haunts. It grows in swamps throughout the U. S. and southern Canada.

All the orchids of this genus are cross-fertilized through the agency of insects. The long slender spur, of most of them, is peculiarly adapted to the tongues of sphinx moths and some of the butterflies. In trying to reach the extreme end of the nectar tube, the moth presses its face into the opening. Its large eyes come in contact with a sticky button to which two pollen masses are attached by slender stalks. When the head is withdrawn these are firmly attached to the eyes. When he reaches the next flower, these masses are in the correct position to be deposited on a sticky stigma, just where they belong. While we might think a moth would be greatly inconvenienced by these incumbrances, we must remember that his eyes are composed of numerous small ones so that the loss of sight of a few is unnoticed. 


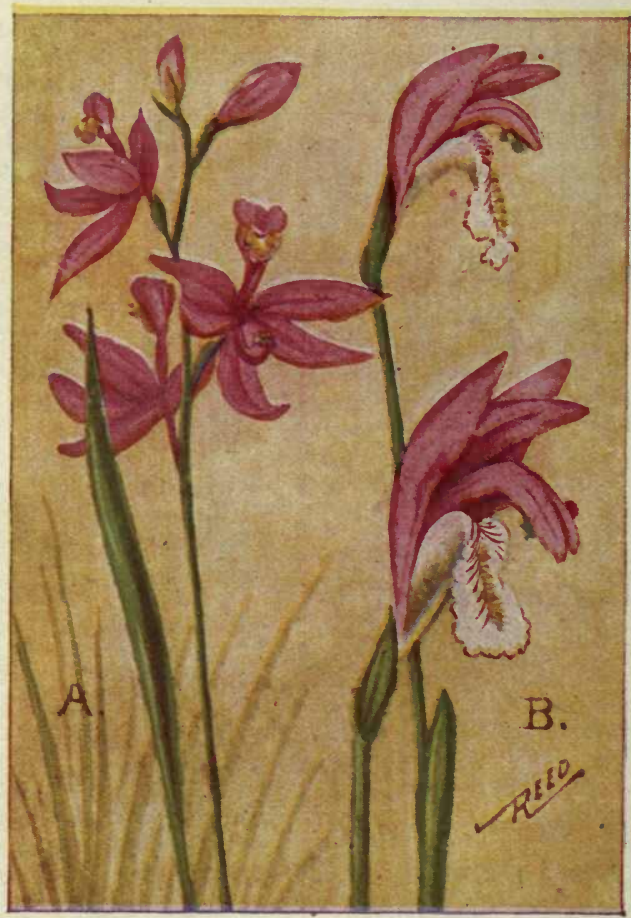

A. Grass Pink; Calopogon. Calopogon pulchellus.

B. Arethusa. Arethusa bulbosa. 


\section{Wild Flowers East of the Rockies}

CALOPOGON; GRASS PINK (Calopogon pulchellus) is an exquisite orchid with a loose raceme of four to twelve delicate pink flowers, at the top of a scape ranging from 6 to 15 in. long. The flowers are apparently upside down as the lip is at the top; it is narrow at the base but broadens into a broad hooked tip, crested on the under side; the column, just below the lip, has a stigma at the end, and just below is a two celled antler, each cell containing two pollen masses. A single grasslike leaf sheathes the flower scape near its base, as it rises from the solid bulb. It grows in deep swamps and bogs, from Newfoundland to Minn. and south to the Gulf, flowering in June and July.

ARETHUSA; INDIAN PINK (Arethusa bulbosa) has a solitary magenta-pink blossom topping its slender scape that rises from 5 to $10 \mathrm{in}$. in height. The petals and sepals are similar in shape and in their proper positions at the top of the flower; the lip rises, then abruptly turns downwards, broadens and is adorned with three to five yellow and white crests; margin of lip wavy and sometimes spotted with crimson. A single linear leaf is hidden in a sheath at the base of the scape; it only protrudes after the flowering season. From Newfoundland to Minn. and south to Pa. and Mo., Arethusa has been found blooming in swamps during May and June.

CALYPSO (Calypso bulbosa) is a rare and locally distributed orchid found along the northern edge of the U. S. and in Canada. It has a single magentapink flower at the top of a slender scape 4 to 8 in. long. The sepals and petals are similar and ascending; the lip is sac-shaped similar to that of the genus Cypripedium; it is spotted with madder-purple and has three rows of glass-like hairs near its division. A single oval, wavy, veiny leaf grows on a triangular petiole from the corm at the base of the scape. 


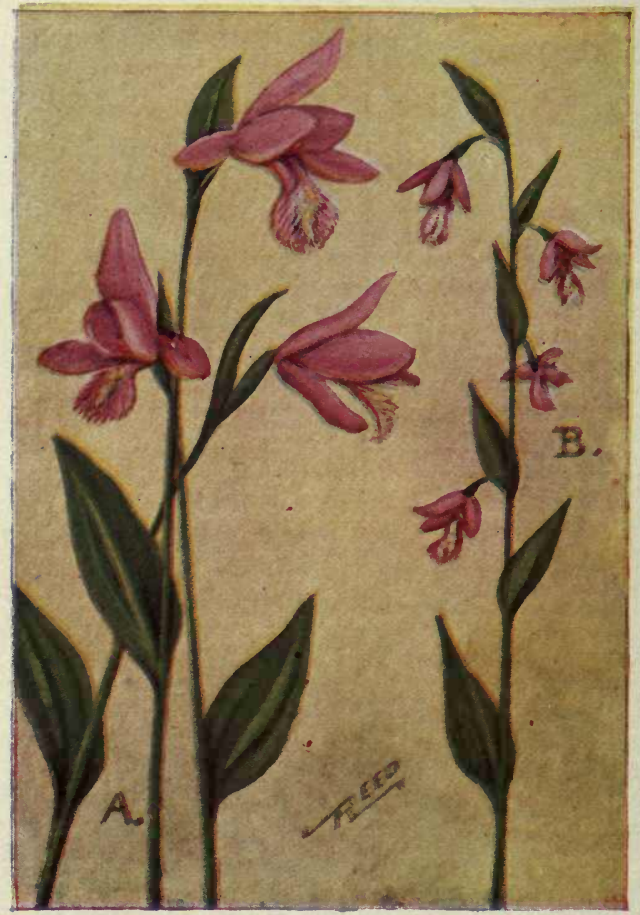

A. Snake Mouth; Pogonia. Pogonia ophioglossoides. B. Nodding Pogonia. Pogonia trianthophora. 


\section{Wild Flowers East of the Rockies}

POGONIA; SNAKE-MOUTH (Pogonia ophioglossoides) is another of our attractive orchids that leads the enthusiast a merry chase, often through miles of tangled swamp, before he finally discovers it in some almost impenetrable bog. It has been my experience that, in the southern parts of their ranges, all the rare orchids are more easily get-at-able than in northern United States, perhaps because in the North they are hunted so persistently and plucked so freely when found, that they can survive only in the most out of the way places.

Snake-mouth is delicate, pure pink in color and slightly fragrant. Its pollen is not in stemmed masses but is showered on the back of a visiting insect as he backs out of the flower. The stem is from 8 to 13 inches high, bearing at its top a single flower; sepals and petals are similar in shape; the lip is spatulate, prominently crested with yellow and white, and toothed and lacerated. About midway of the flower stem is a single oval leaf and just below the flower is a smaller bract-like one. Pogonia grows in swamps from Newfoundland to Minn. and southwards to the Gulf of Mexico, flowering during June and July.

NODDING POGONIA (P. trianthophora) has a leafy stem from 2 to 8 inches high. From two to eight small oval leaves alternately clasp the stem; the flowers, which number from one to six, appear singly from the axils of the upper leaves, nodding on slender peduncles; they are small, magenta-pink and with ovate, three-lobed lips. It is locally distributed from Me. to Wisc. and southwards.

Pogonia divaricata is a southern species found in pine barrens from N. J. to Ga. The plant stem, clasped by a single oblong leaf at its middle, is 8 to 20 in. high and bears a single large flower with ascending brown sepals, pink petals and a 3-lobed lip. 


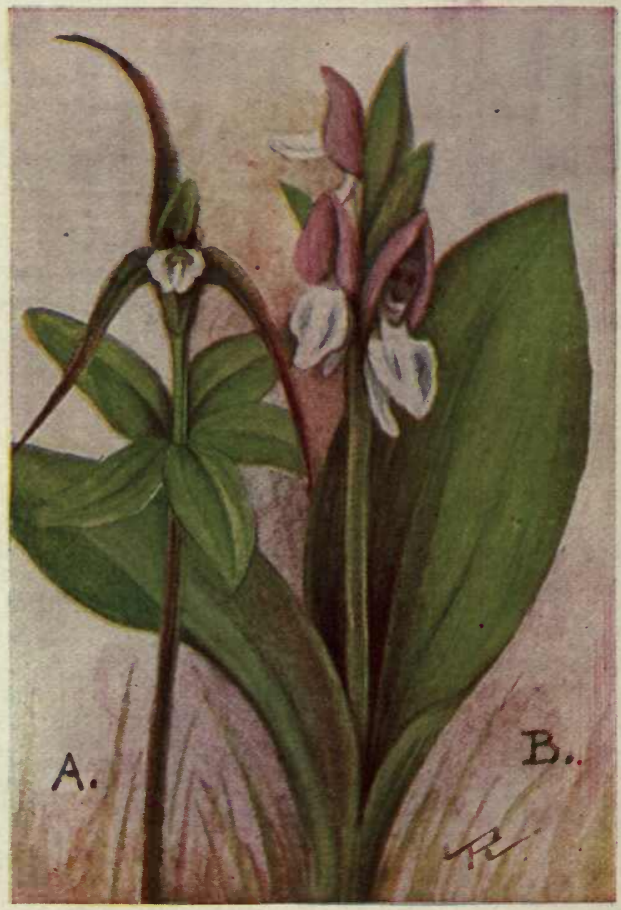

A. Whorled Pogonia. Pogonia verticillata. B. Showy Orchis.

Orchis spectabilis. 
WHORLED POGONIA (Pogonia verticillata) has a single flower on a long stem, 8 to 12 in. high; the sepals are greenish-yellow, long, linear, with the edges rolled or folded together; the petals are oblong-lanceolate and purple; the lip is also purple, wedged-shaped, three-lobed and with a hairy crest down the middle. Five lanceolate and stemless leaves are in a whorl about the stem just below the flower. It is a peculiar, inconspicuous plant found locally in moist woods from Me. to Wisc. and southwards.

SHOWY ORCHIS (Orchis spectabilis) is a charming early blooming orchid found in flower from April to June in moist woods, often under hemlock trees. Two broad, ovate, deeply ribbed, beautiful green leaves sheath the flower scape at its base. The four to twelve flowers are loosely racemed at the top of the scape which is from 5 to $10 \mathrm{in.} \mathrm{high.} \mathrm{The} \mathrm{magen-}$ ta-pink petals and sepals are united to form a hood; the lip, curving abruptly downwards, is broadly ovate and white; each flower has a short spur and is bracted.

The Showy Orchis is our only true native Orchid. It secretes plenty of nectar in the flower spurs and, consequently, is visited by many insects, most valuable of which are bees. As she presses her head firmly in the mouth of the flower to drain the bottom of the tube, her face ruptures the thin membrane of a pouch containing two sticky buttons carrying pollen masses. These become firmly attached to her eyes; the slender stalks holding the pollen bend forward bringing it directly in front of her head, and it is deposited on the awaiting stigma of the next flower visited; surely a wonderful way for Nature to insure cross pollenization.

This species is found throughout the U. S. Another with a single leaf and with the flower lip spotted with magenta is local farther north. 


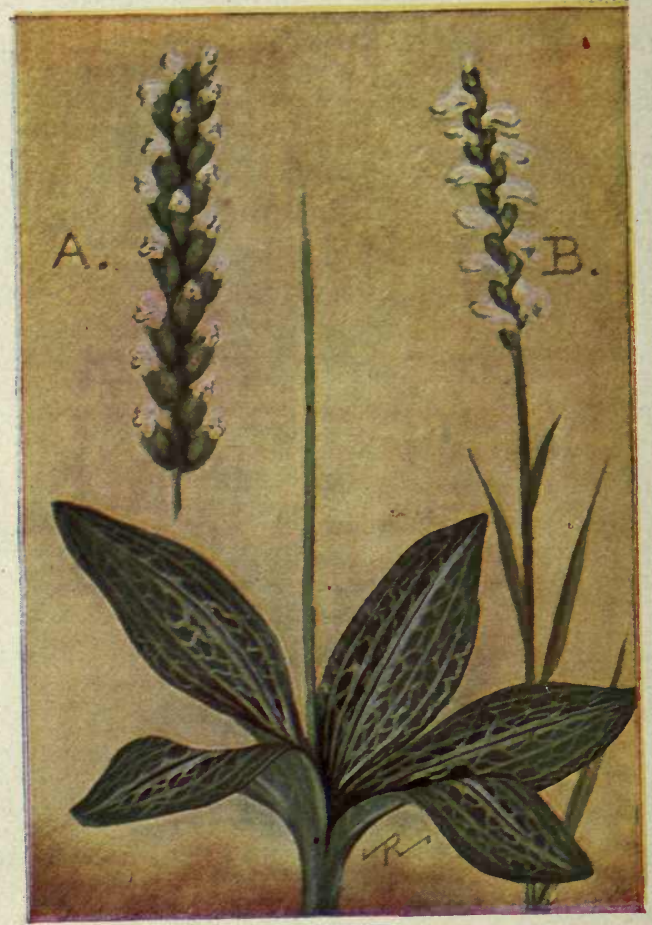

A. Rattlesnake Plantain. Epipactis ophioides. B. Ladies Tresses. Spiranthes cernua. 
RATTLESNAKE PLANTAIN (Epipactis pubescens) is a common representative of a genus having the most beautiful of leaves, all basal and radiating from the fleshy, creeping rootstalk. The leaves are ovate, pointed, dark bluish-green, with five to seven prominent white nerves and many reticulations between them. The scape is 6 to 15 in. high and carries at its top a densely flowered raceme of small white flowers; lip small and sac-shaped, sepals and petals united to form a hood.

This Plantain is quite common and often grows in large beds in dry woods, especially coniferous ones. Because of its beauty and the fact that its leaves last through the winter, it is in demand and freely used for ferneries. It is found in the whole of the U. S., flowering in July and August.

E. repens ophioides has its flowers in a loose 1-sided raceme. The leaves have five white veins and numerous dark cross ones. Has a more northern distribution than the last species.

E. decipiens has densely flowered 1-sided racemes and plain or faintly marked leaves. It is found from Quebec to the Pacific and southwards.

LADIES TRESSES (Spiranthes cernua) is so named because of the braided arrangement of its flowers. The leaves are few, grass-like, sheathing the scape near its base. The scape is 6 to 15 in. high, has several small bracts and ends in a 2 or 3-ranked spiral raceme of white or creamy flowers; petals and upper sepal joined, lateral sepals lanceolate; lip ovate-oblong with a rough tip. Common in moist fields or woods from Me. to Minn. and southwards.

SLENDER LADIES TRESSES ( $S$. gracilis) is slender, has its flowers in a single-ranked 1-sided or slightly twisted raceme; lip green, with a white wrinkled margin. Leaves small, ovate basal. Found in dry ground from N. S. to Manitoba and southwards. 


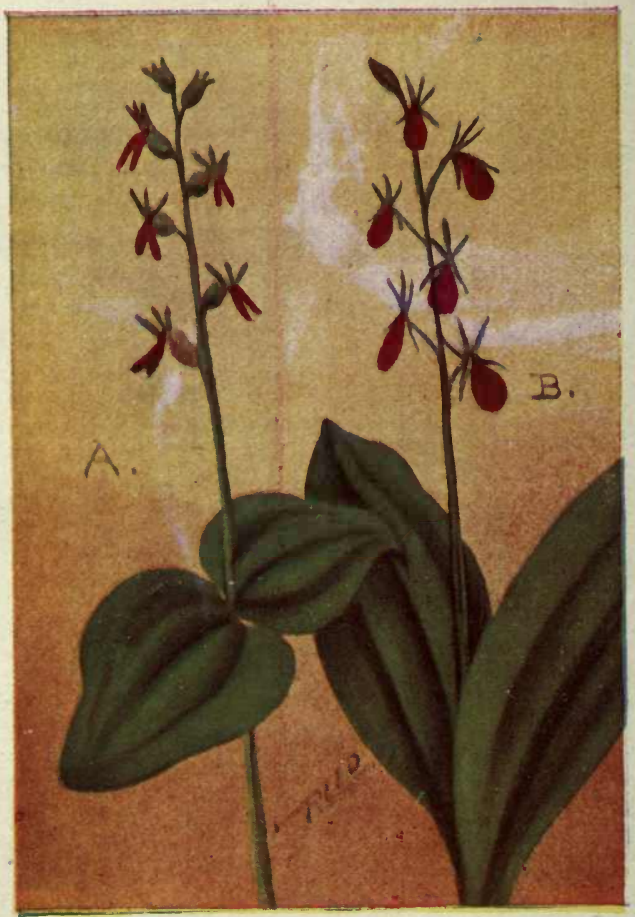

A. Heart-leaved Twayblade.

Listera cordata.

B. Large Twayblade.

Liparis liliifolia. 
HEART-LEAVED TWAYBLADE (Listera cordata) belongs to a genus containing five species. They may readily be recognized by the two heart-shaped or ovate leaves clasping the flower stem, oppositely, about half way up. The flowers are either madderpurple as in the present species, or greenish.

Like most of the Orchids, they are largely or wholly dependent upon insect aid for fertilization. The weight, or shock, of an alighting insect on the broad lip causes a small gland within the flower to rupture and cover the pollen, just below with a sticky fluid that causes it to adhere to the head or body of the insect and thus be transferred to the next flower.

The stem of this species is from 3 to $10 \mathrm{in.} \mathrm{high.}$ At the top is a few flowered raceme; the sepals and petals are similar and spreading; the lip is drooping, longer, two-cleft and madder-purple in color. This species flowers during June and July in swampy woods from N. J. to Colo. and northwards to the Arctic coast.

TWAYBLADE (Liparis lilifolia), although having the same common name, is of a different genus. It is a more attractive plant, having two broad basal leaves and larger flowers with a broad ovate lip. It grows in woodland from Me. to Minn. and southwards.

CORAL ROOT (Corallorrhiza maculata) is so named because of its angular, branching, brownish, corallike root. The scape is from 10 to 18 in. high; its only leaf appears as a sheath near.the base. The flowers are madder-purple, in a loose raceme; the sepals and petals are small, similar and ascending; the lip and column are white, spotted with purple, the former being two-lobed. There are five species of Coral Root, all destitute of green foliage, and differing only slightly in the flowers. They are found in spruce woods from Me. to British Columbia and southwards. 


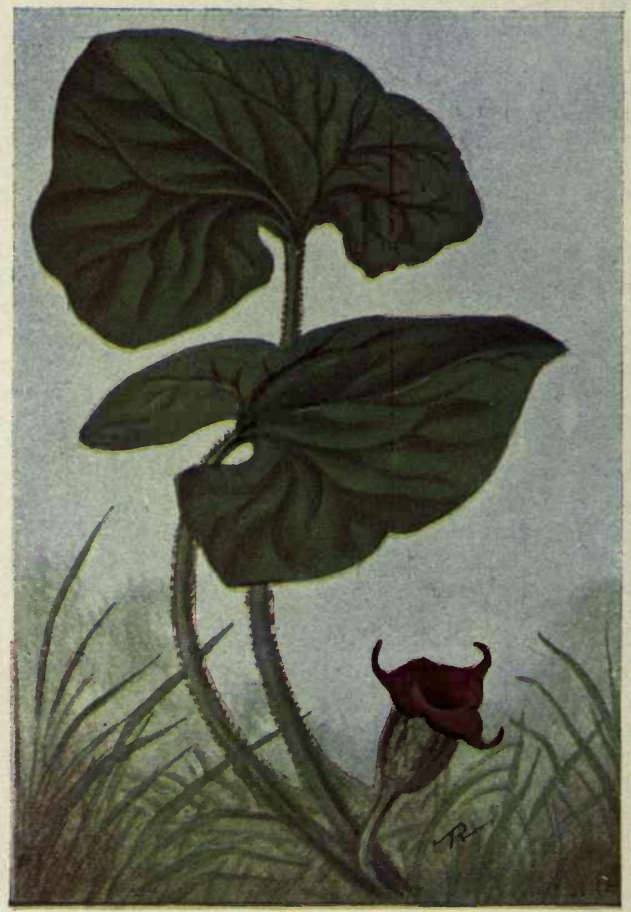

Wild Ginger.

Asarum canadense. 


\section{Wild Flowers East of the Rockies}

\section{BIRTHWORT FAMILY (Aristolochiaceae).}

A small family of low herbs or twining vines, with but two genera and few species.

WILD GINGER (Asarum canadense) may be found flowering in rich woods during April and May, from Me. to Mich, and southwards. It has two, large, heart-shaped leaves on long petioles from the base; deep green above and lighter below, soft, wooly and handsomely veined.

The leaves are very beautiful, but it is the solitary flower that makes this plant so interesting. Small, dully colored, on a weak, short stem that barely raises it above ground and often leaves it concealed by the dead leaves that carpet the woods in early Spring. Really, the flower is quite attractive. Why should it not raise its head that it might be noticed by everybody? A careful watch will convince the observer that all flowers are so constructed and so placed that they serve the best interests of the plant. So it is with this species. It blooms early, before butterflies and moths appear; it needs no bright colors to attract insect friends, as the urn-shaped flower cup makes an excellent refuge for many small, early flies. It also provides these flies with an abundance of pollen for food; in return, they unwittingly carry some away with them on their bodies and leave it at the door, or stigma, of another blossom. The stigma of this flower matures before its anthers ripen so only pollen from another, earlier blossom will serve to quicken the seed.

The flower is bell-shaped, with three short, sharplypointed, spreading lobes; six stamens with short anthers and a thick style with six radiating stigmas. Another species (grandiflorum), found in Va. and $\mathrm{N}$. $\mathrm{C}$. has but one leaf and flowers twice as large, or two inches in length. 


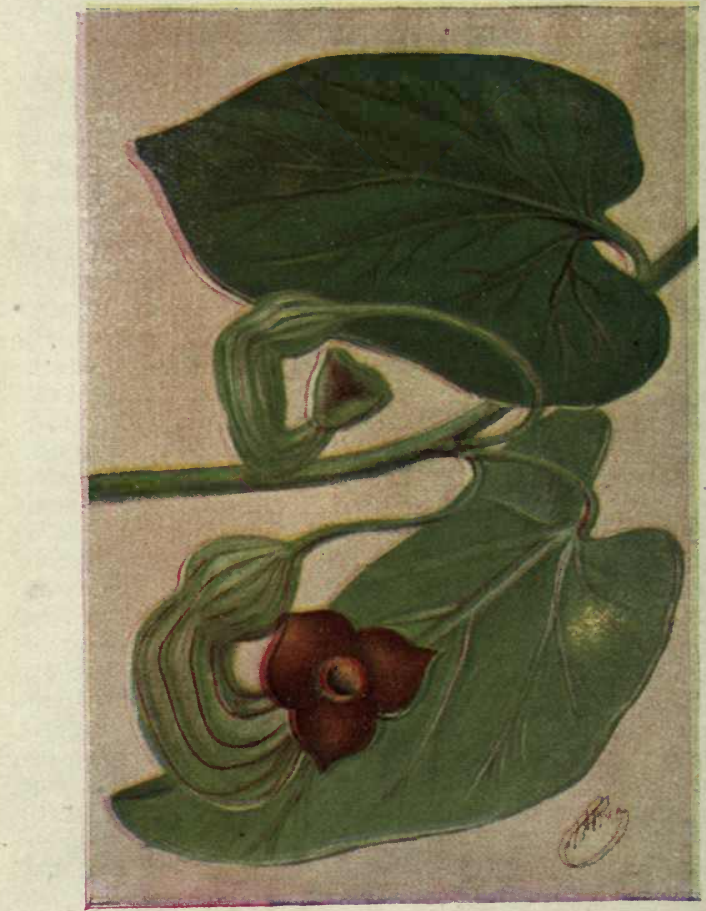

Pipe Vine; Dutchman's Pipe. Aristolochia macrophylla. 
VIRGINIA SNAKEROOT (Aristolichia serpentaria) is a low herbaceous vine with a wooly stem from 8 to 20 in. long, with several pointed-oblong leaves with heart-shaped bases alternating along it. The dull greenish-yellow flowers are on short peduncles from the root; the calyx tube is bent in the form of a letter S, with three obtuse, spreading lobes. It flowers in June and July in rich woods from Conn. and Mich. to the Gulf of Mexico.

PIPE VINE; DUTCHMAN'S PIPE (A. macrophylla). The Dutchman's Pipe is chiefly a southern plant or vine, being found from $\mathrm{Pa}$. and Minn. southwards. It has a woody, climbing stem that may attain lengths of from 10 to 40 feet. It is often used to decorate porches and trellises. The very large, deep green, veiny leaves that alternate along the stem are very beautiful. In the dull, greenish-yellow flowers, however, lies the chief interest of the botanist. Its stigma matures and withers away before the ripening of the pollen, thus making the plant dependent upon insects for its perpetuation.

Besides furnishing a hiding place in its tube, it secretes at the bottom a few drops of nectar as an added attraction for its winged visitors. The throat is filled with tiny hairs, all pointing inwards, so ingress is easy but egress impossible. Entering insects are held prisoners, living upon the nectar, until the stigma withers and pollen ripens; after this the hairs in the throat lose their rigidity and the pollen-dusted and well fed prisoners are allowed to escape. Their memories are poor or the pollen feast is well worth the imprisonment for they usually immediately hie to another blossom and force their way in, of course pollenizing the flower in so doing.

It almost seems as though some of these highly specialized plants were human and had reasoning power. 


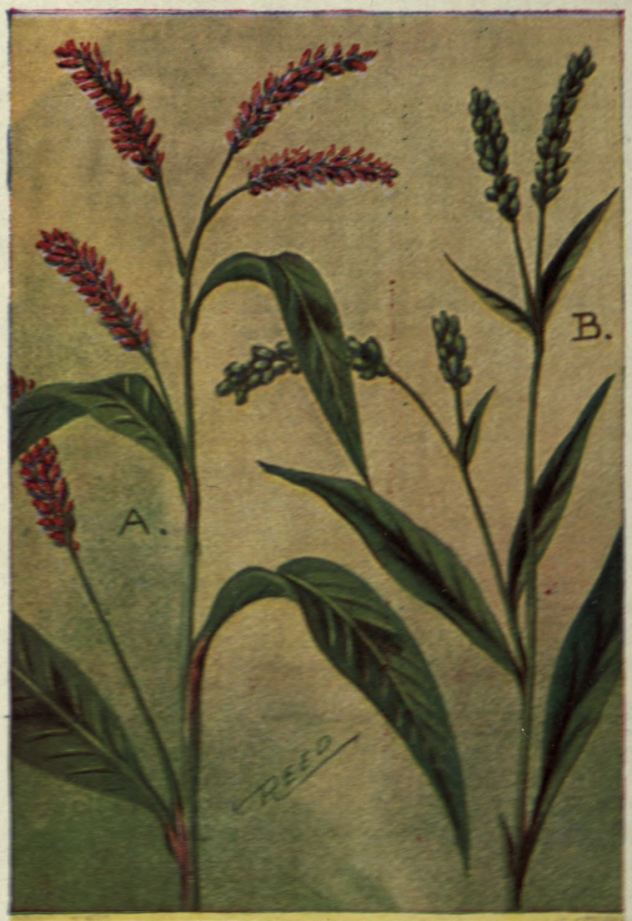

A. Lady's Thume; Persicaria.

Polygonum persicaria.

B. SMartwEed.

Polygonum Hzdropiper. 


\section{BUCKWHEAT FAMILY (Polygonaceae).}

This family contains a great variety and great number of species. It is divided into seven genera and many of these are further divided. They are all inconspicuous in flower and most of them are regarded as obnoxious weeds. The genus Rumex, to which our common Sorrels belong, contains seventeen species: that of Polygonum, which contains the Knot weeds, has 32 species included in its six sub-genera. The scope and size of this book prevents even mention of the majority of these, so we have selected types most common, most conspicuous and most interesting.

FIELD or SHEEP SORREL (Rumex acetosella has dioecious flowers, - that is staminate and pistillate ones grow on different plants. They are tiny, perfect, greenish at first but later turning dark red, on branching spikes. The leaves are arrow-shaped, on slender petioles from the base, but smaller ones alternate along the plant stem that grows from 6 to $12 \mathrm{in}$, high; they are very acrid to the taste and usual ly turn reddish as the season advances, especially if in a dry locality. It is very common and a trouble. some weed everywhere.

LADY'S THUMB; PERSICARIA; KNOTGRASS (Polygonum persicaria) (EUROPEAN), This is a very common weed everywhere in damp places, especially about farm houses. The small, crimsonpink flowers are in dense spikes terminating the branching stems that are from 1 to 3 feet high. The lanceolate, pointed leaves, that alternate along the angled and sheathed stem, are rather rough and usually have a dark triangular spot in the middle.

COMMON SMARTWEED; WATER PEPPER (P, hydropiper) has similar shaped flowers of a greenish color. The leaves are lanceolate and very acrid. It is very abundant in wet places throughout our range, 


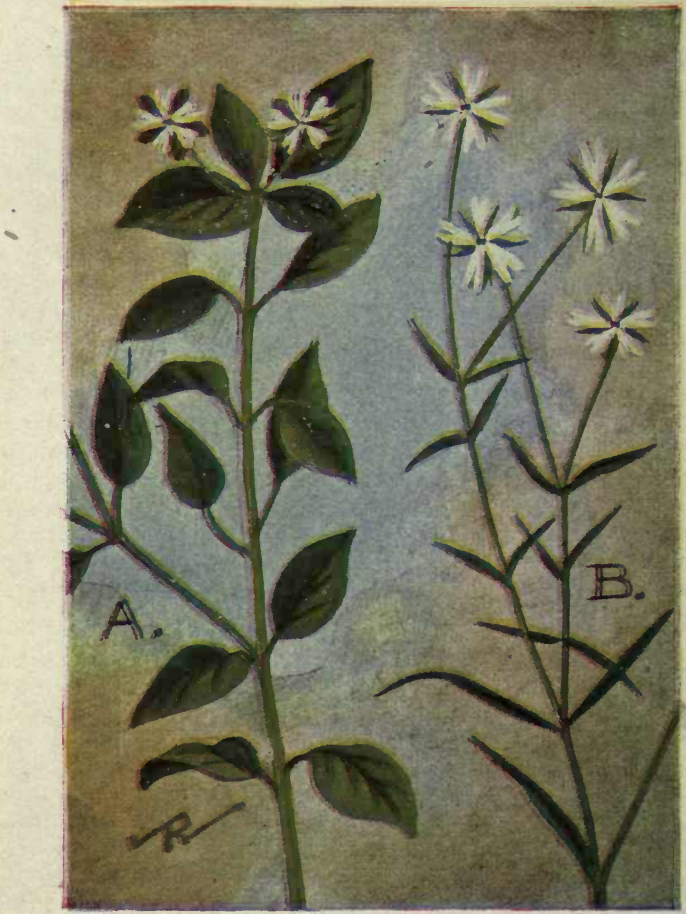

A. Chickweed.

Stellaria media.

B. Stitchwort.

Stellaria longifolia. 


\section{Wild Flowers East of the Rockies 105 \\ PINK FAMILY (Caryophyllaceae).}

This is a very large family containing some of our most beautiful flowers. They are herbs, agreeing in having smooth-edged leaves growing oppositely and in having the plant stem usually swollen at its junction with the leaves. The flowers have either four or five petals and usually twice as many stamens.

COMMON CHICKWEED (Stellaria media) (EUROPEAN). Although this is an introduced weed, so hardy and prolific is it that probably it now exceeds in numbers, any of our indigenous plants. It grows profusely about dooryards and along roadsides everywhere. The flowers are small, so tiny that they are often unnoticed, even by those who take pleasure in feeding the leaves to the pet canary. The corolla consists of five white, very deeply cleft petals, and the calyx of the same number of larger and longer green sepals. The leaves are ovate, small, opposite, on small stems about the length of the leaves. The plant stem is either simple or branched and ranges from 2 to 10 in. in height.

LONG-LEAVED STITCHWORT (S. Iongifolia) has larger flowers than the last, but the petals are very narrow and so deeply cleft as to appear to be ten in number instead of five. The sepals are nearly but not quite as long as the petals. The stem is weak and usually supported by surrounding grasses or vegetation. The leaves are small, linear and pointed at both ends. Common everywhere in wet places.

MOUSE-EARED CHICKWEED (Cerastium arvense) has much larger and broader petals with rounded lobes, giving them something the appearance of mouse ears. Sepals short; leaves lanceolate; stem downy, 4 to $10 \mathrm{in}$. high. Common in dry or rocky places. 


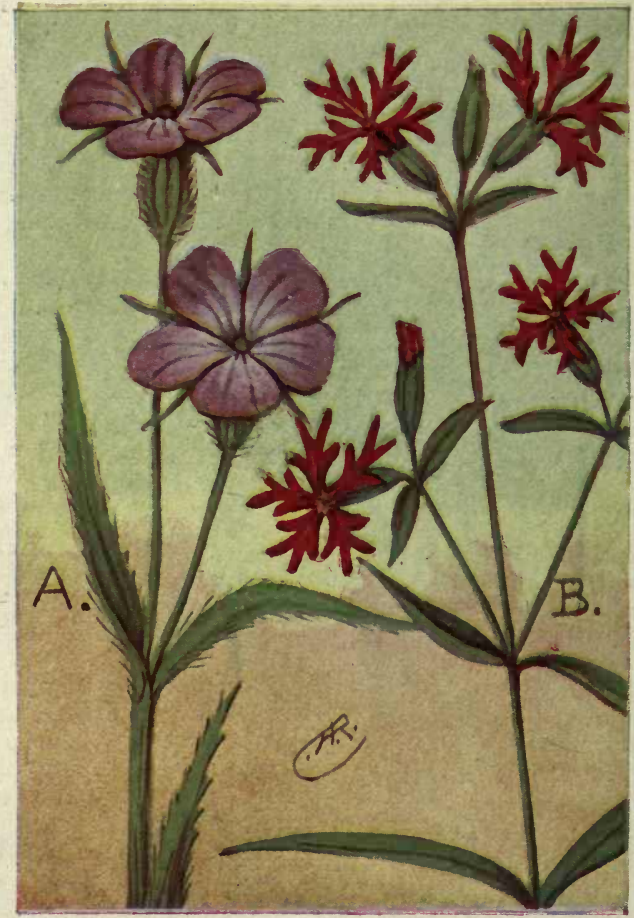

A. Corn Cockle. Agrostemma githago. B. RagGed RobiN. 
Wild Flowers East of the Rockies

CORN COCKLE (Agrostemma githago) (EUROPEAN). The Corn Cockle is very closely related to the Campions (genus Lychnis); in fact it was formerly classed with them and is now by some authors. It is an annual with an erect and rather downy stem; it branches but slightly, each branch being terminattd by one or two large handsome magenta flowers with an expanse of one to two inches. The calyx is densely hairy, as are also the lanceolate leaves that grow oppositely on the stem. The stem is swollen at the leaf junctions and is weakened at that point so that it breaks quite readily; this is one of the characteristics of most of the members of the pink family. In Europe, this is often called the Corn Flower; it represents one of the typical plants of the harvest fields. In this country we find it as an escape from gardens or in waste places near grain fields.

\section{RAGGED ROBIN (Lychnis Flos-cuculi) (EURO-} PEAN). This species, which is also known as Meadow Lychnis, is noteworthy because of the slashed appearance of its five crimson petals. The flower calyx is deeply ribbed and is of a brownish purple color, as is also the upper part of the flower stem; both are sticky and hairy. The name is, of course, from the ragged appearance of the petals and also from their color which approaches that of the breast of the English Robin Red-breast. It is sometimes found in waste land or moist places where it has escaped from cultivation.

MULLEIN PINK (L. coronaria) (EUROPEAN) is a showy plant with bright crimson petals, five in number; the calyx teeth, or sepals, are twisted. The oblong leaves are seated oppositely upon the stem. The whole plant, stem, leaves and calyx, is quite wooly. It has escaped from gardens and is now locallp found from Me. to N. Y. and Mich. 


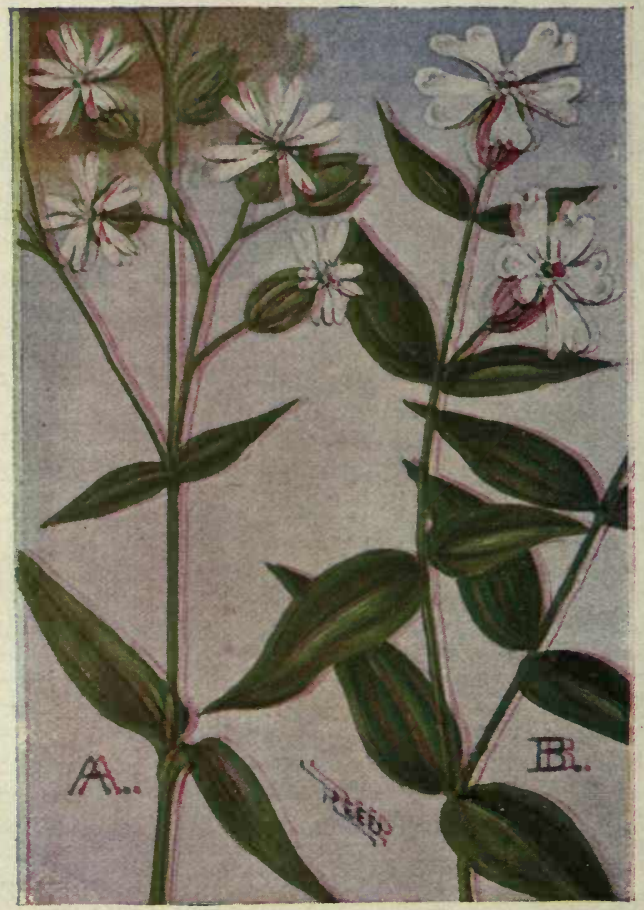

A. Bladder Campion.

Silene latifolia.

B. Evening Lychnis.

Lychnis alba. 


\section{BLADDER CAMPION (Silene latifolia (EURO- PEAN.)}

We have several Campions, some natives and some introduced. The present species was brought to us from Europe. It has very unusual blossoms, in that the calyx is very inflated, almost globular and handsomely marked with darker green, so as to often give it a very similar appearance to that of the citron melon. The five white petals are cleft in twain for nearly their whole length. The plant branches but slightly, each branch being terminated by a loose, few-flowered cluster. The leaves are quite smooth and grow oppositely on the stem, slightly clasping it with their bases; they are ovate-lanceolate in shape and deep green in color. This species is a very hardy one. It is a perennial and plants spring up from the same root year after year, while numerous new ones are formed from the flower seeds.

It is a common escape from gardens and may be found blooming from June to August along roads or in dry waste places from Quebec to Minn, and south to Va. and Mo.

\section{EVENING LYCHNIS; WHITE CAMPION (Lychnis alba) (EUROPEAN).}

This is another attractive species introduced from Europe. It gets its common name from the habit of opening towards evening and closing the following morning. The petals are white, deeply cleft and crowned at the base with little petal-like divisions; the calyx is inflated and often deep pink on the ribs. As usual with members of the family, the leaves are smooth edged and in pairs, oppositely on the stem that grows from one to two feet high. These are also found in waste places and along roadsides where they have escaped from gardens, from Me. to N. J. and west to Ohio. 


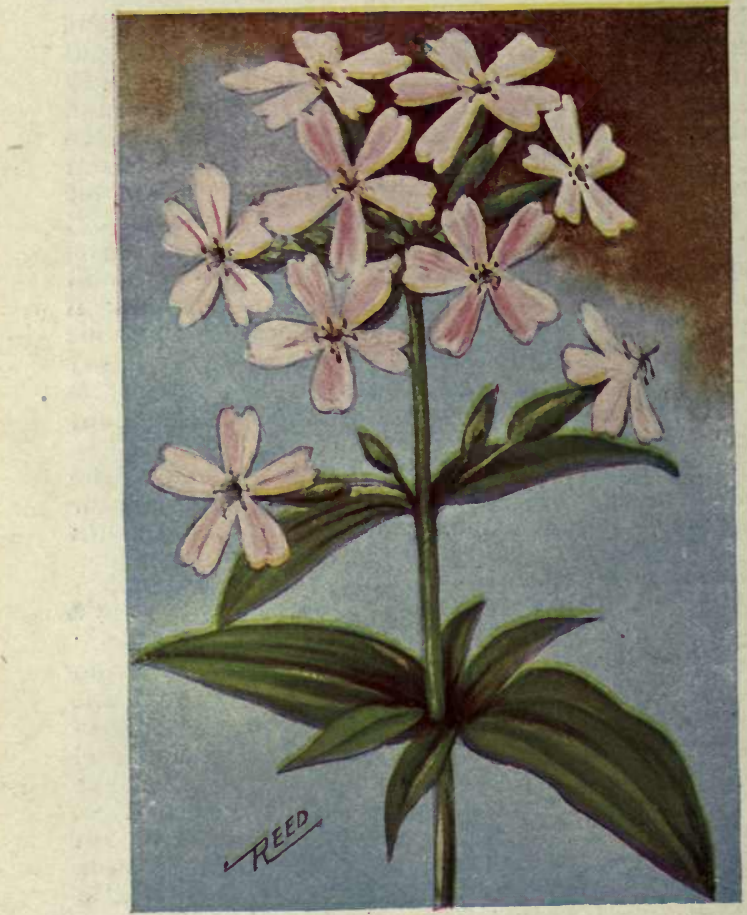

Bouncing Bet; Soapwort. Saponaria officinalis. 
BOUNCING BET (Saponaria officinalis) (EUROPEAN). This is probably the most hardy and the most widely distributed of our adventive members of the Pink Family. It increases very rapidly by means of underground runners as well as by seed. It is very commonly known as "Soapwort," because of the fact that the mucilaginous juice from the crushed leaves will form a lather if they are shaken in water; it is said that it was, in olden days, used for washing purposes.

The plant stem is quite stout, smooth, erect and sparingly, or not at all branched. At the top is a corymbed, or flat-topped, cluster containing many flowers; petals, notched or sometimes quite deeply cleft, and with an appendage at the top of the long claws that, bent at right angles, enter the long, tubular, veined, greenish, 5-notched calyx. The ten stamens are divided into two sets of five, one longer than the other and maturing first. The flowers vary in color from a delicate, beautiful shade of pink to white, depending upon the amount of shade and the dryness of the soil in which they grow. The leaves are ovate-lanceolate, united opositely on the stem by short clasping petioles.

From July until September, Soapwort blooms profusely in waste places along railroad beds and beside dusty roads where few other flowers are able to flourish. It was one of the first of foreign flowers to be introduced into this country and has been established as a wild flower for several centuries.

COW-HERB (S. Vaccaria) has a more slender and branching stem and pale red flowers in a loose cory$\mathrm{mb}$, the central flowers of which bloom before the outer ones; the petals are not crowned. It is adventive from Europe and may occur anywhere. 


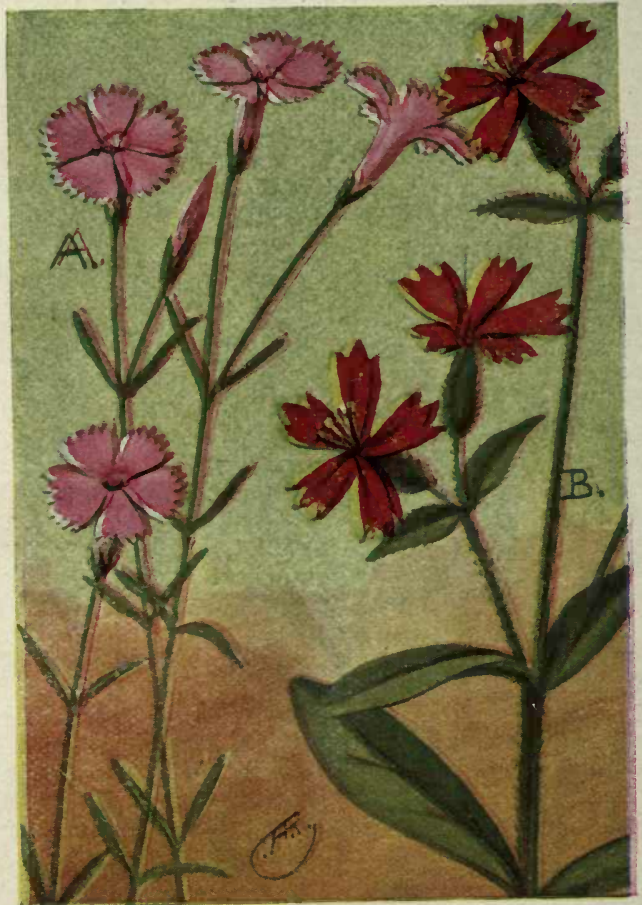
A. Maiden Pink.
Dianthus deltoides.
B. Fire Pink; Catchfly.
Silene virginica. 
MAIDEN PINK (Dianthus deltoides) (EUROPEAN) A handsome rose-colored Pink that has become naturalized along the Atlantic coast and is quite abundant in some localities, in fields and waste places. The flowers grow singly, or in pairs, at the ends of the branching stem; the petals are broad, wedge-shaped and finely-toothed; the calyx is tubular, five-toothed, veined and subtended at the base by two ovate bracts that are about half its length. The leaves are numerous, small, short and narrowly lanceolate.

The Maiden Pink is one of the most graceful in form of the family, hardy and a favorite under cultivation.

DEPFORD PINK (D. Armeria) (EUROPEAN) has narrower petals with longer claws; the five-toothed calyx is very long, equal to the flower tube, and downy; its two bracts are also long and linear. The pink flowers grow in small clusters at the ends of branching, downy, erect stems from 6 to 18 in. high. It is now distributed from Me. to Mich. and south to Va., being most abundant near the coast.

FIRE PINK; CATCHFLY (Silene virginica) is one of our most brilliantly colored wild flowers, the petals being either deep crimson or scarlet; the five petals are oblong, 2-cleft, long-limbed and five in number. The lower leaves are thin and spatulate, the upper ones oblong-lanceolate. Both stem, leaves and calyx are rather hairy. This species is found in open woods from southern N. J., western N. Y. and Mich. southwards.

WILD PINK (Silene pennsylvanica) is another beautiful native species, with bright pink flowers and a low, sticky stem, the upper leaves are small, and the numerous basal ones, lance-shaped. It is rather common from Me. to N. Y. and southwards. 


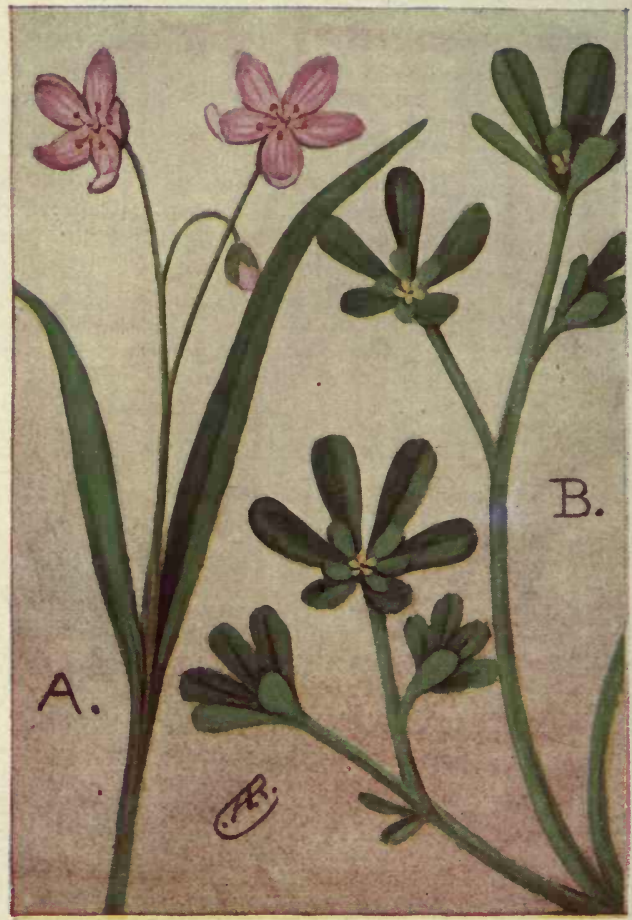

A. Spring Beauty.

Claytonia virginica. B. Purslane.

Portulaca oleracea. 


\section{Wild Flowers East of the Rockies \\ PURSLANE FAMILY (Portulacaceae).}

A small family of low herbs, with thick succulent leaves and perfect but unsymmetrical flowers, that is with unequal numbers of petals and sepals.

SPRING BEAUTY (Claytonia virginica), although very delicate in appearance, is among our earliest flowering plants. It may be found blooming during the cold wintry month of March, during tempestuous April, as well as during the warmer May days.

The beautiful flowers have a pale flush of pink, with veins of deeper pink radiating from the yellowish base. One would expect flowers blooming at this season to be rather hardy, but we find this species to be very frail; the flowers close almost immediately upon being plucked, and only open during bright, sunny weather. The weak stem is usually very crooked and is often prostrate on the ground; two linearlanceolate leaves clasp it oppositely about half way up. The flowers are in a loose, long-peduncled cluster, the buds assuming a drooping position. The opened flowers, somewhat less than inch across, have five petals, two sepals and five golden stamens that mature before the stigma. It is found in moist woods from Me. to Mich. and south to the Gulf.

\section{PURSLANE (Portulaca oleracea) (EUROPEAN).} This is a very common weed, naturalized from the old world. It has a prostrate, juicy stem and thick fleshy leaves; the latter are wedge-shaped with rounded ends. The stem is very branching and spreads or radiates from the root in an attractive circular form. The flowers are tiny, solitary and yellowish, seated in the whorls of leaves that terminate the branches. The five petals spread only in the morning sunshine. Found in waste places anywhere and possibly indigenous in the Southwest. 


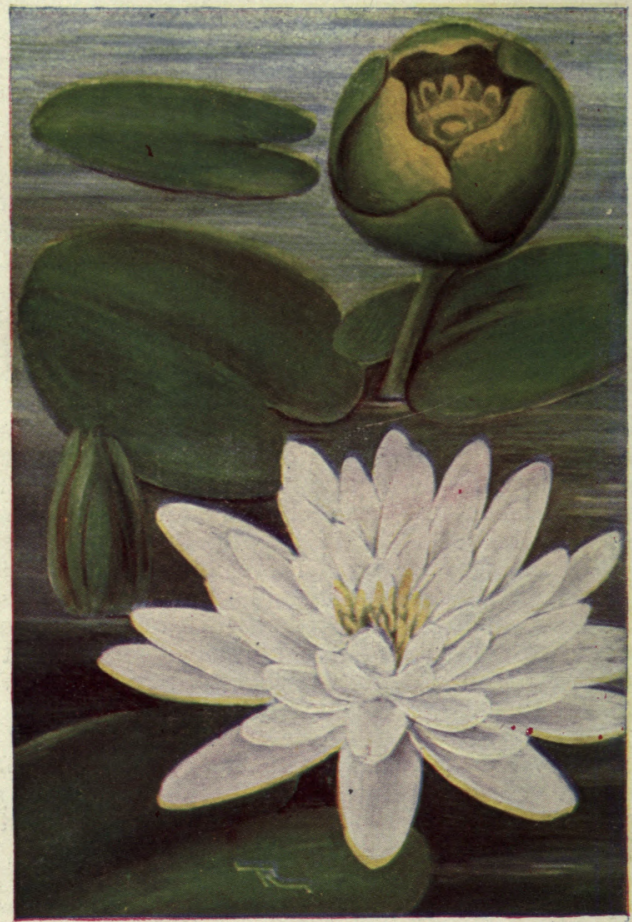

A. Cow Lily; Yellow Pond Lily. Nymphaea advena. B. Water Lily. Castalia odorata. 


\section{Wild Flowers East of the Rockies \\ WATER LILY FAMILY (Nymphaecae).}

COW LILY; YELLOW POND LILY (Nymphaea advena). This lily has the misfortune of being closely related to and associated with the Water Lily, one of our most beautiful, most fragrant, and most prized wild flowers. It is another case of "comparisons are odious," and the yellow lily suffers in consequence. It is, however, not unattractive and is interesting in its make-up. The leaves are thick, rough, ovate, slit or lobed to the stem, which is long and hollow. The flower is raised above the surface of the water on a long hollow stem. What appear to be six large green and yellow petals are in reality sepals; the real petals are numerous, stamen-like, inserted with the very numerous stamens under the goldenyellow rayed disk that forms the stigma.

The Cow Lily is very common in still or stagnant water, often growing so profusely that passage in boats is almost impossible. It is found throughout the United States and southern Canada.

WATER LILY; WATER NYMPH (Castalia odorata) needs no introduction to our readers. To my mind, it leads all other flowers in beauty, grace, purity and fragrance. It is composed of four sepals, greenish on the outside and whitish within, and numerous pure, waxy-white petals; the golden-yellow stamens, and anthers mature later than the radiating central stigma. The flowers open soon after sunrise and close shortly after noon; they sometimes are gigantic in size, often spreading five or six inches across. It flowers from June to Sept. in ponds or slow-moving water, everywhere; in ponds near the coast, we find a variety (roseae) that has pink or bright pink-red flowers. The rounded, lobed, longstemmed leaves are pinkish beneath. 


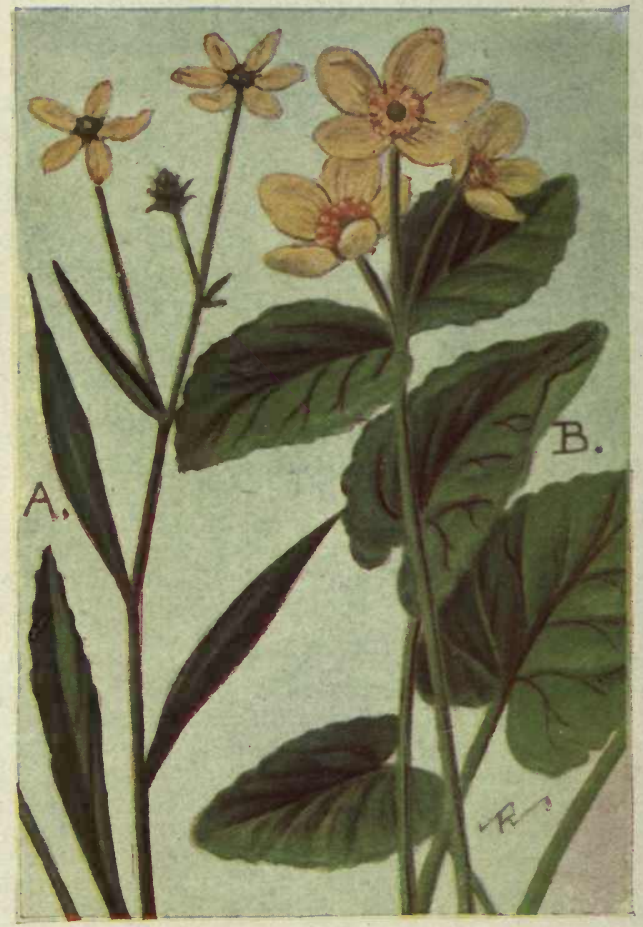

A. Water Plantain.

Ranunculus laxicaulis.

B. Cowslip; Marsh Marigold.

Caltha palustris. 


\section{CROWFOOT FAMILY (Ranunculaceae).}

A very large and very diversified family of herbs, or sometimes wooly plants, divided into three tribes containing 23 genera. Practically all of them have very acrid juices, some of them very poisonous.

WATER PLANTAIN (Ranunculus laxicaulis) is a rather common marsh-inhabiting buttercup, with five to seven narrow yellow petals. The stem is stout but rather weak and angled, at each joint sending out a clasping lanceolate, almost toothless leaf. The flowers, which are about 3-4 in. broad, are on long peduncles terminating the branching stem that rises from 1 to $21-2$ feet. It is found in bogs, ditches and muddy places from Me. to Minn, and south to the Gulf of Mexico.

STIFF WATER CROWFOOT (R. circinatus) has white flowers and sessile leaves that are entirely submerged; the latter are rigid and do not collapse when taken from the water, as do those of the more common White Water Crowfoot (R. aquatilis). The first species is rather rare and the last very common in slow flowing waters throughout the United States.

MARSH MARIGOLD (Caltha palustris) is the very common marsh herb usually, but erroneously, called "Cowslip." Its leaves are very commonly used and marketed for food. The flowers are perfect, have no petals but from five to nine (usually the former) golden-yellow, shining sepals and numerous brighter stamens. The stems are hollow and furrowed. The leaves are round kidney-shaped, usually with scalloped edges. Marsh Marigold is abundant in swamps or wet meadows from Newfoundland to Alaska and southwards through the United States, flowering in April and May. 


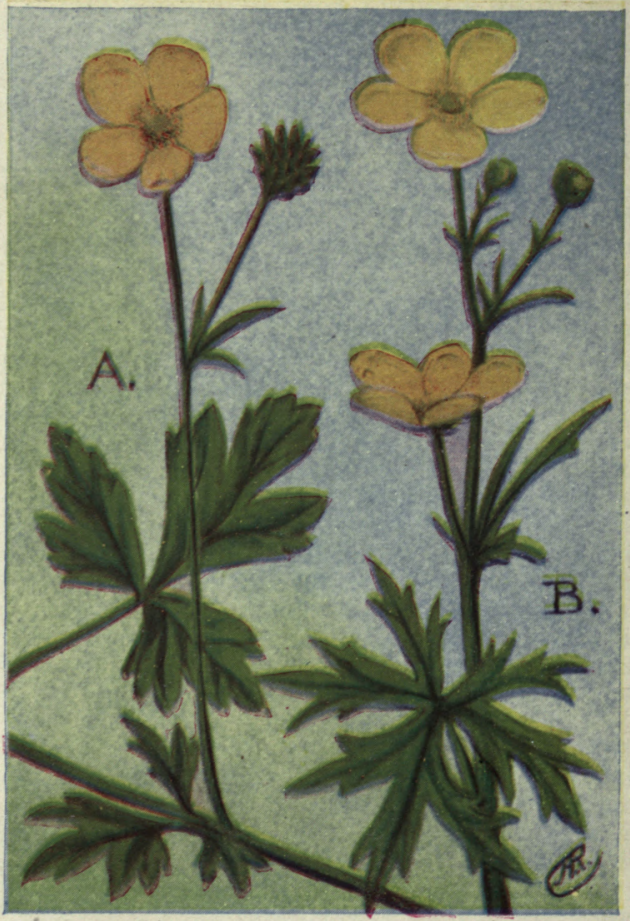

A. Creeping Buttercup. Ranunculus repens.

B. Common Buttercup; Tall Crowfoot. Ranunculus acris. 
CREEPING BUTTERCUP (Ranunculus repens) is, as per its name, a creeping plant. The stem is prostrate, creeping along the ground and striking new roots from the junctions of the leaf and flower stems with the main one. The flowers are large and broadpetalled, both the petals and stamens being a deep shining golden yellow. This species is indigenous in the West, but probably introduced from Europe in the East, where it is found chiefly near the coast, in ditches or along the edges of marshes.

SWAMP BUTTERCUP ( $R$, septentrionalis) is another of the Crowfoots that chooses the wettest of places for its habitat. Its stem is hairy, ascending, from 1 to 2 1-2 feet high. In very wet places some of the stems are usually recumbent and form runners. The leaves are on long petioles, and are 3-parted, each division being stemmed and further divided, notched or slashed. The flowers are rather large, for Buttercups, with broad, oval, shining yellow petals, spreading much wider than the sepals. It is common in moist or shady places throughout our range, flowering from May to August.

COMMON BUTTERCUP; CROWFOOT (R. acris) (EUROPEAN). Even though we have quantities of native Buttercups, it is this handsome foreigner that is the most abundant; this is the species that is found in fields everywhere, the one that delights the little folks and figures in many of their childish games. The opposite picture shows well the character of the flower and its leaves, but paint cannot be made to do justice to the dazzling, shining, golden yellow Buttercup.

The leaves and stems of the Crowfoots are very acrid, but not poisonous; on this account they are shunned by cattle and horses. This accounts in part for their abundance in most fields and pastures. 


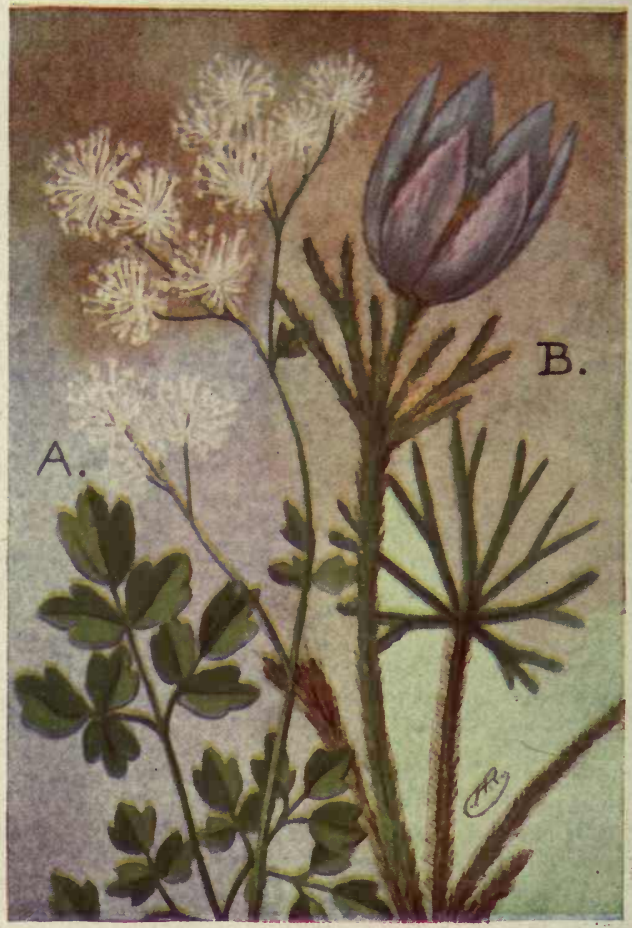

A. Tall Meadow Rue.

Thalictrum polygamum.

B. Pasque Flower. Anemone patens. 
TALL MEADOW RUE (Thalictrum polygamum) is one of the characteristic plants of swamps and edges of streams. It is very ambitious and determined that none of its neighbors shall raise their heads above it. If the surrounding vegetation averages one foot in height, this is sure to attain a height of two feet. Should its neighboring plants be three or four feet high, we will find the plumey flowers of this species triumphantly waving above them on stems five, six or even seven feet tall.

Naturally a flower that thrusts itself so prominently into view, has many insect visitors and is often crosspollenized by them. It is very capable of looking out for itself, for it has often three kinds of flowers on one plant, staminate, pistillate and perfect.

The stalk is rather stout and grooved, pale green, stained with maroon. The long stemmed leaves are many times compounded into small, lobed leaflets of a pale, dull blue-green color. The flowers are in feathery clusters; each individual flower having numerous white filaments, no petals, but usually four or five early falling sepals.

From June to September we may find the mist-like flowers of Meadow'Rue in swamps, from Labrador to Manitoba and south through the United States.

EARLY MEADOW RUE (T. dioicum) is a smaller and more slender species found in open woods and on rocky hillsides. Staminate, brown-tipped flowers grow on some plants and pale greenish pistillate ones grow on others.

PASQUE FLOWER (Anemone patens) has a solitary erect flower with five to seven purplish sepals. Leaves divided and cut into narrow, acute lobes. Both stem and leaves covered with silky hairs. This species is found on prairies from Wis, and Montana southwards. 


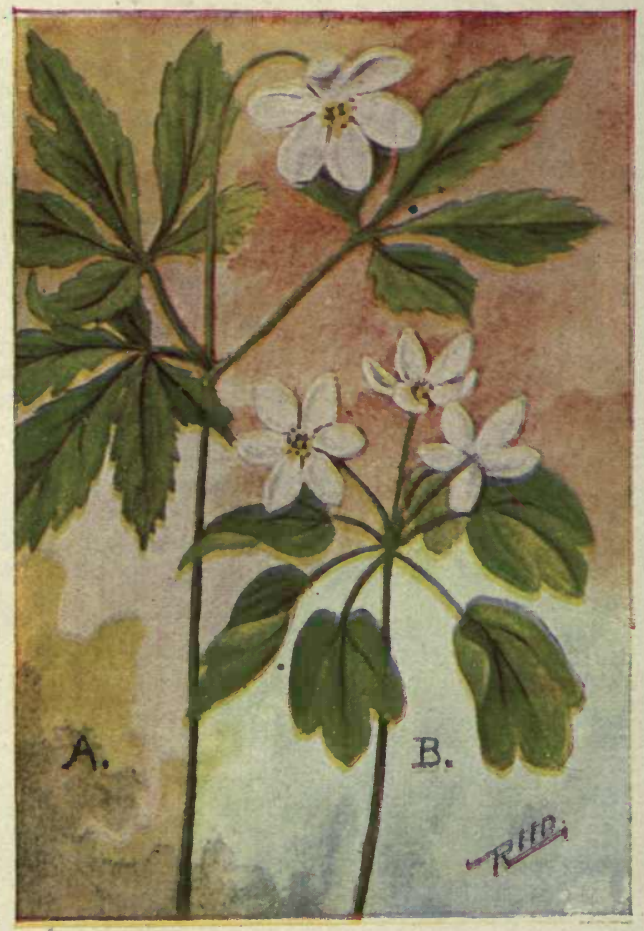

A. Wood Anemone; Wind Flower. Anemone quinquefolia.

B. Rue Anemone. Anemonella thalictroides. 


\section{Wild Flowers East of the Rockies}

WOOD ANEMONE; WIND FLOWER (Anemone quinquefolia) is an exceedingly delicate looking plant, but the fortitude with which it withstands the winds of early April rather belies its appearance. Swayed this way and that, with a violence that threatens to demolish it, it safely weathers the most severe storms and, with the appearance of the sun, its nodding head beckons a welcome to the early bees. Very appropriate indeed is its common name of "Wind Flower."

The stem is slender and 4 to 8 in. high. Three leaves radiate from a point about two thirds up; each on a long stem and divided into three to five, toothed, ovate leaflets. The solitary flower rises on a slender peduncle from the junction of these three leaves with the stem proper. It has four to seven sepals, most often five; white inside and purplish white on their outer surface; numerous yellow and brown-tipped stamens radiate from the base of the greenish pistils; the flower has an expanse of slightly less than one inch, but is rarely seen fully expanded. The very smooth slender stalk grows from an elongated, horizontal rootstalk. The Wind Flower is common in woods or thickets from Nova Scotia to the Rockies and southwards.

RUE ANEMONE (Anemonella thalictroides) is even more slender in form than the Wind Flower. From four to nine sepals, (usually six), numerous orange-tipped stamens and a broad stigma make up the flower; there are several of them on exceedingly slender peduncles, rising from the whorl of leaves. The latter are on slender stems, have heart-shaped bases and three-lobed ends; rather small, pale green above and with a whitish bloom below. Its root is a cluster of tuberous rootlets. It is found in the same localities and the same range as the last species, with which it associates. 


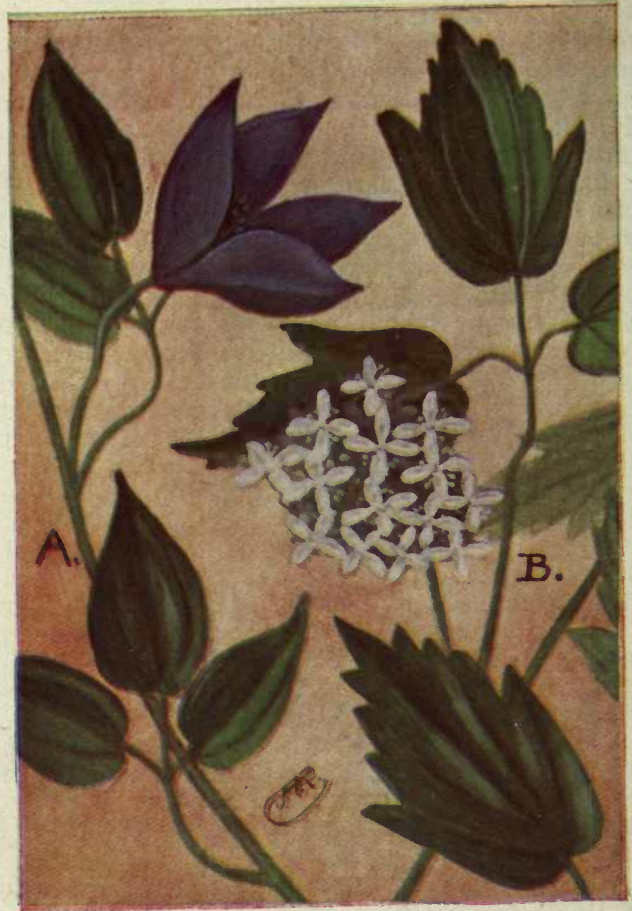

A. Purple Virgin's Bower.

Clematis verticillaris.

B. Virgin's Bower; Clematis.

Clematis virginiana. 
PURPLE VIRGINS BOWER (Clematis verticillaris) is probably the most rare species of Clematis. It grows in rocky hilly or mountainous woods, most abundantly in northern portions of its range, which is from Quebec to Hudson Bay and south locally to Del. and $\mathrm{Pa}$. It is a climbing woody vine, supporting itself by the bending or clasping of the leaf stalks. The flowers grow singly, on long stems from the axils of the leaves or from the end of the vine. They are large and handsome, the four thin, purple, pointed, translucent sepals spreading from two to four inches when fully expanded. Both sides of the sepals are covered with silky hairs or down along the edges. The sepals are usually much concaved, forming a cup-shaped flower; the petals are very small, spatulate shaped; numerous greenish-white stamens are clustered in the center of the flower. The leaves are divided into three leaflets, ovate, pointed, with a heart-shaped base.

MARSH CLEMATIS (C. crispa), found in the southern states is the most beautiful species; flowers about the size of the last, with bluish-purple, crimped, or wavy-edged sepals, sweet scented.

LEATHER FLOWER (C. Viorna) is a larger and tougher species with a woody stem that often reaches a length of 10 feet. The flower calyx is bell-shaped, the four pointed sepals being very thick and leathery. It grows in rich soil, usually climbing over bushes, from $\mathrm{Pa}$. to Mo. southwards, flowering in May and June.

VIRGIN'S BOWER (Clematis virginiana) is a beautiful, graceful, climbing, twining vine found throughout our range. The small greenish white flowers, with four or five sepals, grow in clusters from the leaf axils; staminate and pistillate ones are on separate plants. In Fall, the beautiful silky plumes of the seed pods gives this species the name of "Old Man's Beard." 


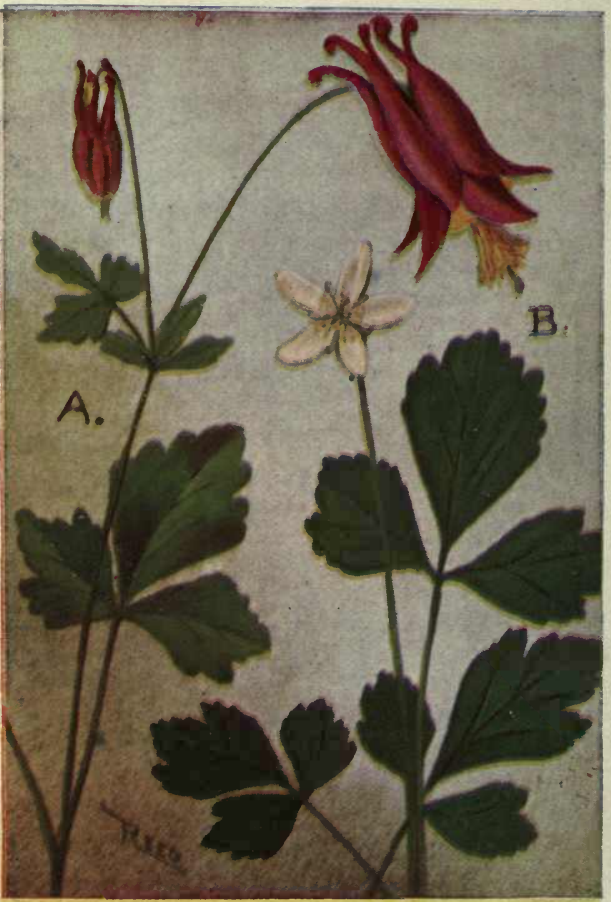

A. Wild Columbine.

Aquilegia canadensis.

B. Gold Thread.

Coptis trifolia. 
WILD COLUMBINE (Aquilegia canadensis) is one of our typical, early woodland plants, graceful in form and beautiful in flower. It grows in rocky woodland throughout our range, flowering from April to June. The slender roots are perennial and the plant will grow up each year if this is undisturbed. Unfortunately, from the nature and shallowness of the soil among the rocks, and the tough wiry, slender stem, it is usually plucked out by the roots by those gathering flowers. I trust that those of my readers who find it necessary or advisable to gather this, or other flowers, will make sure that at least the root be left for future production.

The flowers are well shown on the opposite page; the stem is very slender, wiry and graceful, quite branching and attaining heights of one to two feet. The flowers are heavy, which causes them to nod from their slender, thread-like peduncles. A quantity of nectar is secreted in the base of each red spur, serving to attract butterflies, moths and often the Ruby-throated Hummingbirds, for these birds are very partial to red colors. Columbine blossoms from April to July throughout our range, on rocky, wooded hillsides.

GOLDTHREAD (Coptis trifolia) is a small woodland plant receiving its name from the slender, threadlike, golden-yellow roots; these are very bitter and are used for the concoction of several medicines. These roots are characterisitc and readily identify the species. The leaves also are peculiar in that they are evergreen, and deep shining green in color, 3 -parted and notched, on long petioles from the root. The white flower has five or six early falling sepals; it is usually solitary on a scape from 3 to 6 in. high. Common in rich woods throughout U. S. and Canada. 


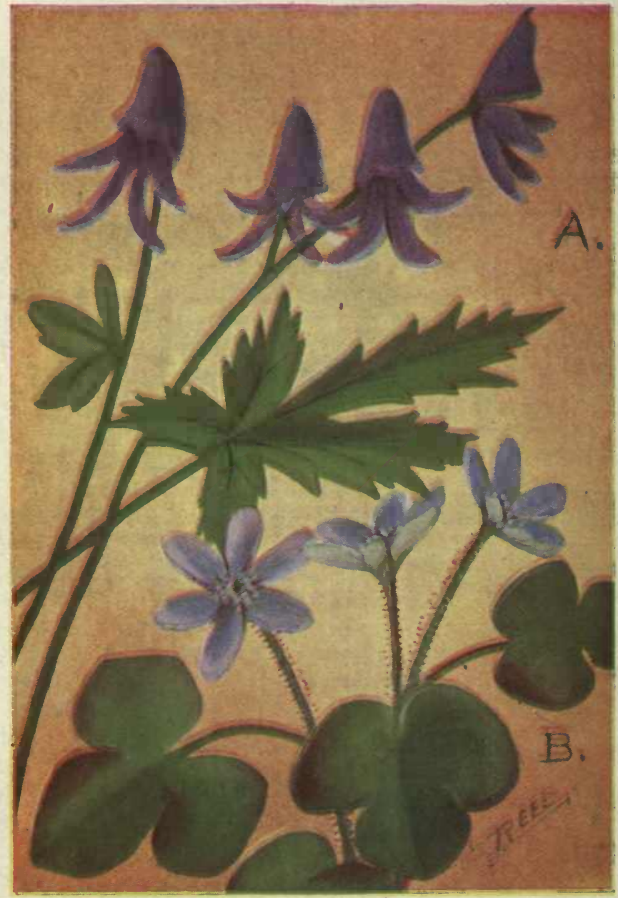

A. Monkshood; Aconite. Aconitum uncinatum.

B. Hepatica; Liverwort. Hepatica trilnba. 


\section{Wild Flowers East of the Rockies}

MONKSHOOD; ACONITE (Aconitum uncinatum) is an attractive wild flower with a slender, rather weak, stem often supporting itself against other species. Some of its traits remind one of the Columbine, to which it is closely related, but it lacks the hardy qualities of that species. The flowers are quite large and handsome; they grow in a loose, few-flowered raceme. The five sepals are very unequal in size and shape; the upper one is large and hood-like, and conceals two small petals within it; it has three to five pistils, numerous stamens and three other abortive petals. The leaves are firm, three to five-lobed and notched, on slender petioles. It grows in rich, moist woods from $\mathrm{Pa}$. southwards, flowering from June to September.

HEPATICA; LIVERWORT (Hepatica triloba). I† is always with a feeling of ecstacy that we find or hear the first reported blooming of the reratica, each year; its coming is the first sign of the breaking up of winter. If we except the early-lowering Skunk Cabbage, and many refuse to consider this at all as a flower, the beautiful Hepatica is the first of our flowers to appear. It is seemingly well clad for low temperatures, for its stems are thickly covered with fuzzy hairs; the three-lobed, smootl-ed;sed leaves are rather thick and coarse, lasting tb: ough the winter but turning a ruddy color, while ti:e new ones, that appear with the buds, are light greon anl radiate above the older prostrate ones. A single bius. som appears at the end of each long fuzzy -capt'; it is about one inch broad, has five to ten liale pur. ple or lilac sepals and numerous greenish wicills and yellow anthers; they have a slight fr: . .uce.

Hepaticas grow in smal? - Inries. blomming from March to May in open ...... is to ini N. S to Vialituba and southwards. 


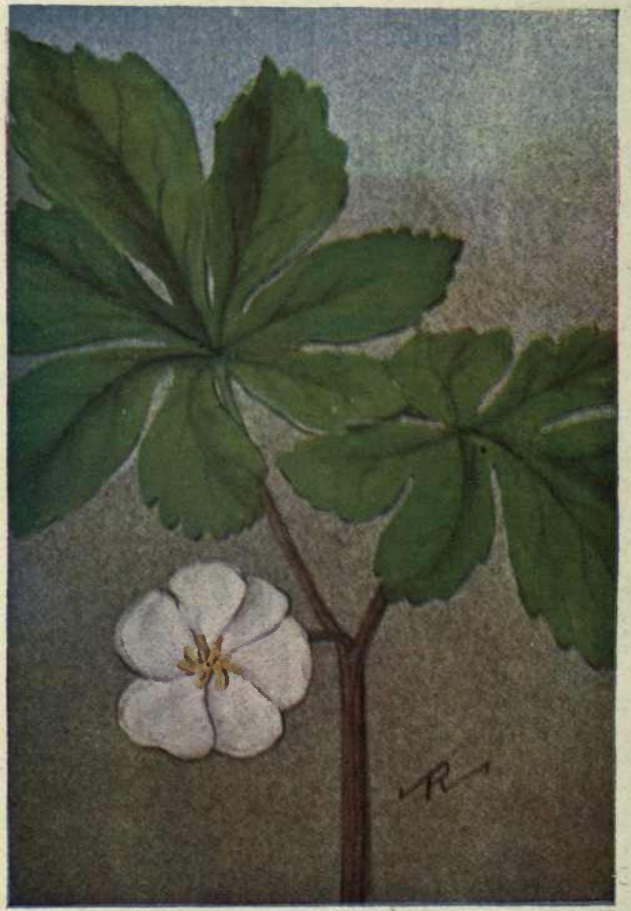

May Apple; Mandrake.

Podophyllum peltatum. 
MANDRAKE; MAY APPLE (Podophyllum peltatum) belongs to the Barberry Family (Berberidaceae), a small family of shrubs or herbs, divided into five genera of but one or two species each. The present species is quite common in rich woods, or in shady, moist ground, from western N. E. to Minn. and southwards, flowering in May. The bare stalk rises to heights of 10 to 12 inches, then branches into two long-stemmed, light green, large, spreading leaves; the latter are five to nine-parted, lobed, notched, and unevenly balanced. From the forked joint of the leaves, hangs a solitary white flower on a short, slender, curving peduncle; this is very delicate, nearly two inches across, and of six petals and twice as many stamens. Other non-flowering stalks bear at the summits, single, large, one-sided, divided leaves.

While the blossom of the May Apple yields no nectar, it is visited by bees in search of pollen and is chiefly fertilized through their agency. The fruit is large and lemon-shaped, yellow in color, ripening in July. It is the fruit that gives it the name of May Apple. It is also known as "Wild Lemon," quite an appropriate name if the fruit alone is considered. While the leaves and stem are poisonous, the fruit is not, but has a peculiar, acid, sickish flavor.

TWINLEAF (Jeffersonia diphylla) is a small, low plant, being only about 8 in. high when in flower. The solitary white flower has eight white petals and half as many early-falling sepals; it grows at the top of a naked scape. The two-parted leaves grow from the root on long petioles; they are bright above and rather whitish below.

Twinleaf is not uncommon in moist woods from $\mathrm{N}$. Y. to Wisc. and southwards; it flowers in April and May. 


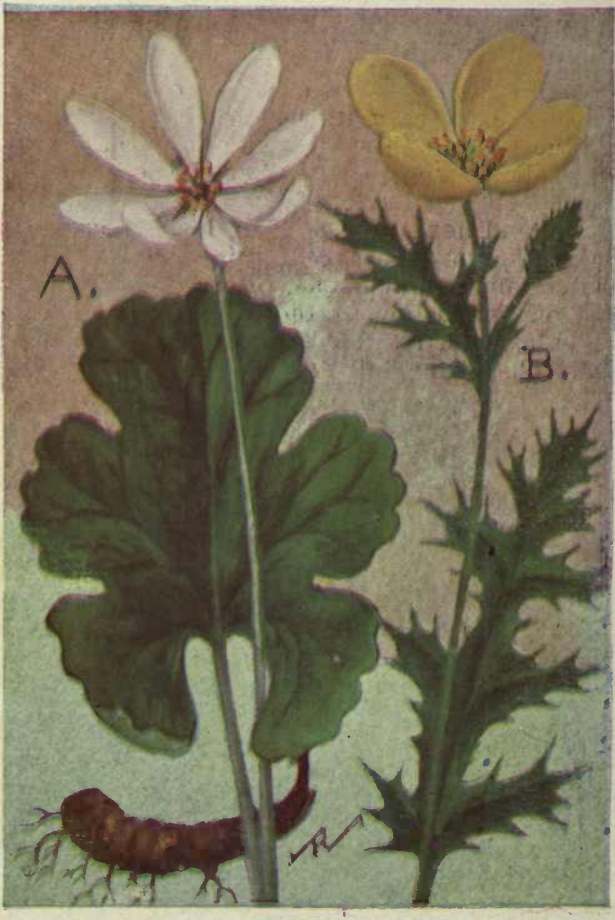

A. Bloonroot.

Sanguinaria canadensis.

B. Prickly Poppy.

Argemone intermedia. 
BLOODROOT (Sanguinaria canadensis). Closely following on the heels of our handsome Hepatica, we find the delicate flowered Bloodroot unfurling its leaves and expanding its flowers in rich, rocky, open woodland. Almost before snow has left, the flower stalk bearing a little bud, closely wrapped in a delicate silvery leaflet, forces its way up through the earth and dead leaves. The leaf unfurls and the flower stalk grows rapidly, forcing the bud up out of its protection; it now opens, the two sheathing sepals falling off, exposing to our view an exquisitelypure, white, delicate blossom; the eight petals are partially closed on dull dayś, but in sunshine spread wide open, one and one-half inches in diameter, exposing the golden center made up of the numerous, yellow-tipped stamens. The flowers are very delicate; the petals stay but two or three days anyway, and a breath of wind may blow them off sooner.

After the flower is gone, the leaf developes rapidly and becomes very large and imposing, with many divisions and lobes. The root is reddish and is filled with a blood-like juice, as is also the stem. This is now used in medicines and was formerly used by Indians for coloring purposes. Bloodroot is common from N. S. to Minn. and southwards.. It flowers in April and May.

PRICKLY POPPY (Argemone mexicana) is a handsome Mexican plant found in the southwestern portions of the United States and, as an escape, in other portions. It has a prickly stem from one to two feet high. The stemless leaves have sharp lobes, also armed with prickles. The flower is bright yellow, has four petals and numerous orange-tipped stamens. The later fruit capsule is about one inch in length and is covered with prickly bristles. The flowers give no nectar, but plenty of pollen to the bees that visit them. 


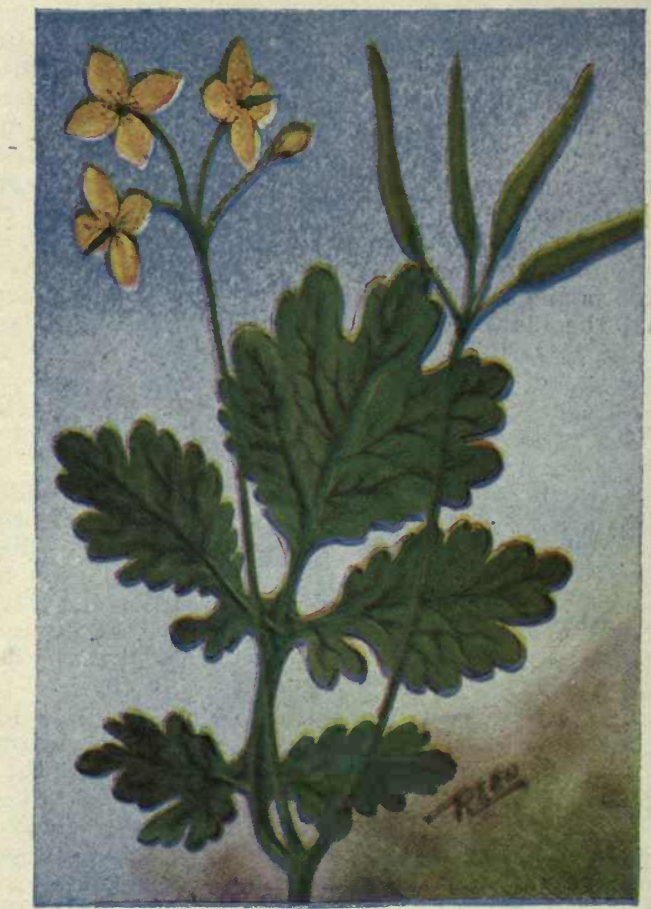

Celandine.

Chelidonium majus. 
CELANDINE (Chelidonium majus) (EUROPEAN). Although this is a stranger in a strange land, having come to us from across the seas, it is by no means backwards and is extending its range with remarkable celerity. It is now abundant almost everywhere in the eastern half of our country. It bids fair, in time, to extend its range to equal that of the English Sparrow, but we trust it will never become a pest as that bird has.

The stem is quite stout and very branching; at the end of each branch is a loose cluster of buds on slender pedicels. These open one or two at a time, so that the plant keeps in bloom for a long time; in fact, the flowering season extends from early in May to the end of September. The flowers are half an inch or more broad, with four golden-yellow petals, a slender, pointed green pistil and numerous yellow stamens. The seed-pod is long and slender; when ripe, it splits at the base and allows the seeds to escape. Towards the end of the flowering season, the continued bloom is marked by the large number of these pods with which the plant is decorated.

The thin, soft leaves are very handsomely divided into three to seven, lobed leaflets. Both stem and leaves have a bright yellow, very acrid juice, that stains everything it comes in contact with. Celandine is often known in Europe as "Swallow-wort" as it is supposed to commence flowering with the coming of the swallows and to cease with their departure. Its generic name also originated in this belief.

CELANDINE POPPY (Stylophorum diphyllum) is a very similar species, both as to leaf and flower. It has fewer flowers than the last, and the seed pod is ovoid in shape and bristly. It is found from Pa. to Wisc. and southwards. 


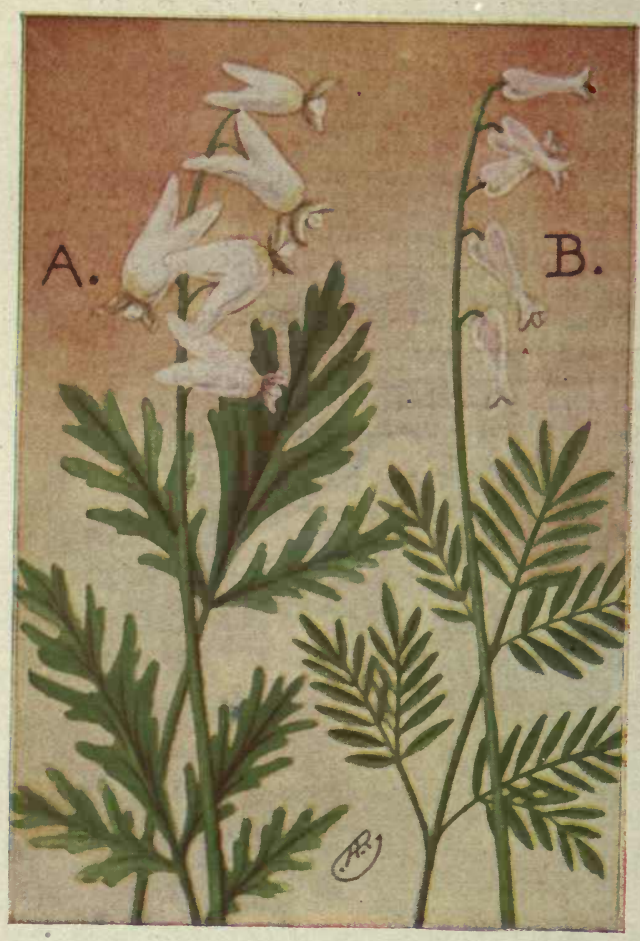

A. Dutchman's Breeches.

Dicentra cucullaria.

B. Squirrel Corn.

Dicentra canadensis. 
DUTCHMAN'S BREECHES (Dicentra Cucullaria). This peculiarly flowered herb belongs to the Fumitory family (Fumariaceae), a family of delicate, smooth plants with watery juices and compound, dissected leaves. One has but to glance at this species to see why it should have received the name it bears. Oftimes objects are fancifully named, and future generations look and wonder, but fail to see the reason for so naming them, but not so with Dutchman's Breeches, for there are the little panties suspended where all may see them.

The flower stalk, proceeding from the root, attains heights of from 5 to 9 inches and bears a loose raceme of four to eight white, inverted flowers; the four petals are united in pairs, two of them forming a large double-spurred sac, and the other two very small petals forming a protection for the stigma. The double sac is white, stained with yellow. The leaves are on long petioles from the rootstalk; they are pale sage-green in color, 3-parted and finely slashed. Dutchman's Breeches may be found blooming in April and May in rich, hilly woods from N. S. to Minn. and south to N:C and Mo.

SQUIRREL CORN (D. canadensis) is similar, but the white-sac-like petals are stained with purple, the spurs are shorter and rounder and the flower is slightly fragrant. The roots have little tuberous appendages resembling grains of corn. This species is found in the same range as the last.

PALE CORYDALIS (Corydalis sempervirens) is also similar in some respects to the foregoing species. The leaves are sagé green, 3-parted, but not slashed as much as those of Dutchman's Breeches. The pale magenta flowers are half an inch long, have a rounded base and two-flanged mouth. It is found from N. S. to Minn. and south to Ga. 


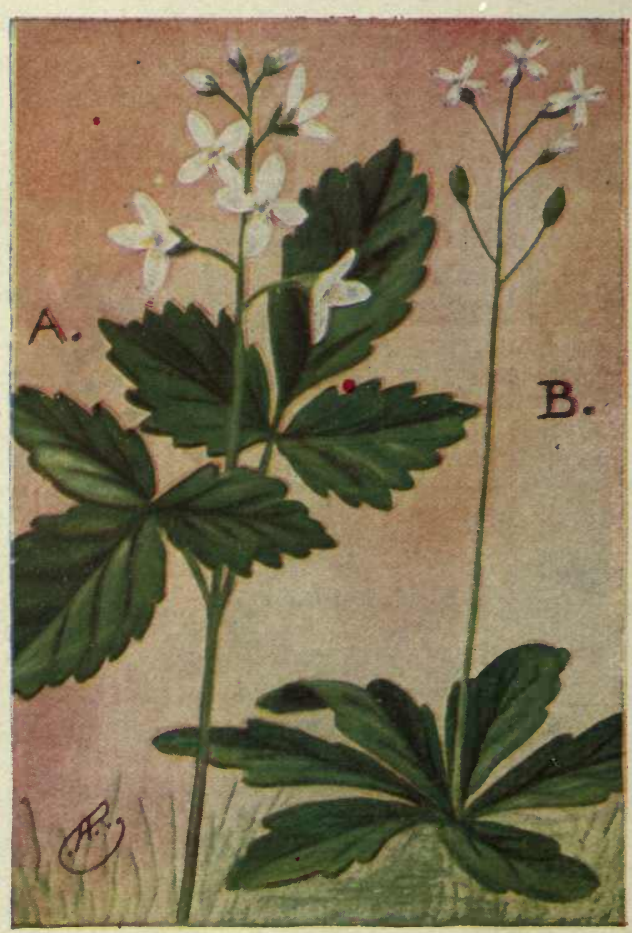

A. Toothwort; Crinkleroot.

Dentaria diphylla. B. Whitlow Grass.

Draba verna. 


\section{MUSTARD FAMILY (Cruciferae).}

A large family divided into eight tribes, thirty one genera and more than a hundred species. All have pungent watery juices, finely dissected compound leaves and cruciform flowers, the four spreading limbs of the petals forming a cross.

TOOTHWORT; CRINKLEROOT (Dentaria diphylla). During the latter part of April or in May we will find white, crosslike flowers of Toothwort often growing side by side with Anemones. Its stem is stout and smooth, and rises to heights of 8 to 12 inches. At the top are the flowers arranged in a loose spike, on short peduncles; they are half an inch wide, have four white petals, the same number of shorter sepals and numerous yellow stamens. Two 3-parted, notched-edged leaves with short stems, are set oppositely on the flowering stalk, above the middle; other larger, similar ones are on long petioles from the rootstalk. Its names are derived from the shape of the root, which is crinkled and with toothlike appendages; it is edible and often used by country fclik as a relish. It is found in rich woods from N. S. to Minn. and southwards.

CUT-LEAVED TOOTHWORT (D. laciniata) is very similar. The leaves are deeply cut into narrow lobes, conspicuously gash-toothed. The root is deep-seated and with larger tubers. This species blooms from April to June in about the same range as the last.

\section{WHITLOW GRASS (Draba verna) (EUROPEAN)} has become quite common throughout our range. It is a weed that we will find along roadsides, waste places or barren fields. The flowers are small, and the four white petals are deeply notched. The scape is from 1 to 5 in. high. The leaves are all basal, lance-shaped and lobed or toothed. 


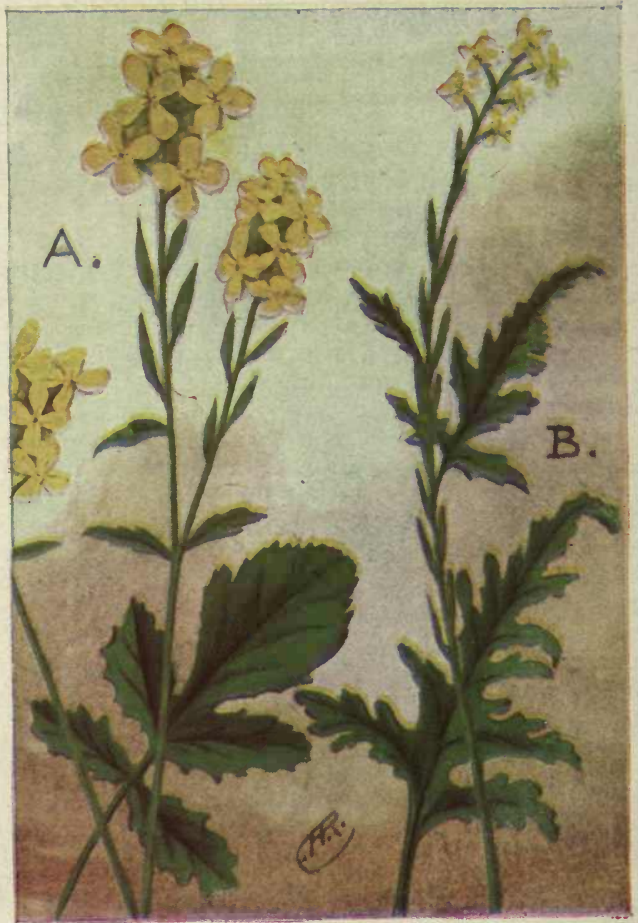

A. Common Black Mustard.

Brassica nigra.

B. Hedge Mustard.

Sisymbrium officinale. 
COMMON MUSTARD (Brassica nigra) (EUROPEAN). Mustard is extensively cultivated in Europe for the small dark brown seeds that form a valuable article of commerce, being used for the table condiment and for various medicinal purposes, such as liniments and the dreaded mustard plaster.

In our country, Mustard is regarded as a pest; it is a very strong, hardy plant, soon over-running sections where it gets a foothold. It is very abundant about abandoned farms and often enroaches upon fields in cultivation; its continued presence in the latter case usually is a sign of shiftlessness on the part of the owner. The stem is very branching and grows to heights of from 2 to 7 feet. The four-petaled, light yellow flowers are in small dense clusters at the ends of the branches; a trail of small, erect seed-pods is left in the wake of the flowers as they continue to bloom along the lengthening stem. The leaves have a large terminal, notched lobe and smaller lateral ones.

CHARLOCK; FIELD MUSTARD (B. arvensis) has slightly larger flowers (over one half inch broad), the seed pods are much longer (nearly two inches) and do not hug the stem as: closely; the outline of the seeds is plainly visible in the pods. The leaves are notched but not divided nearly as much as those of the Common or Black Mustard. It is very common, as an obnoxious weed, everywhere and was also introduced into this country from Europe.

HEDGE MUSTARD (Sisymbrium officinale) (EUROPEAN). This is also a common weed, brought from Europe, that keeps the thrifty farmer everlastingly busy trying to exterminate it. It has tiny, fourpetalled yellow flowers that bloom all summer, along the lengthening stem, and leaves numerous tiny pods closely set against the stem. The leaves are more angular and more finely divided than those of the Common Mustard. 


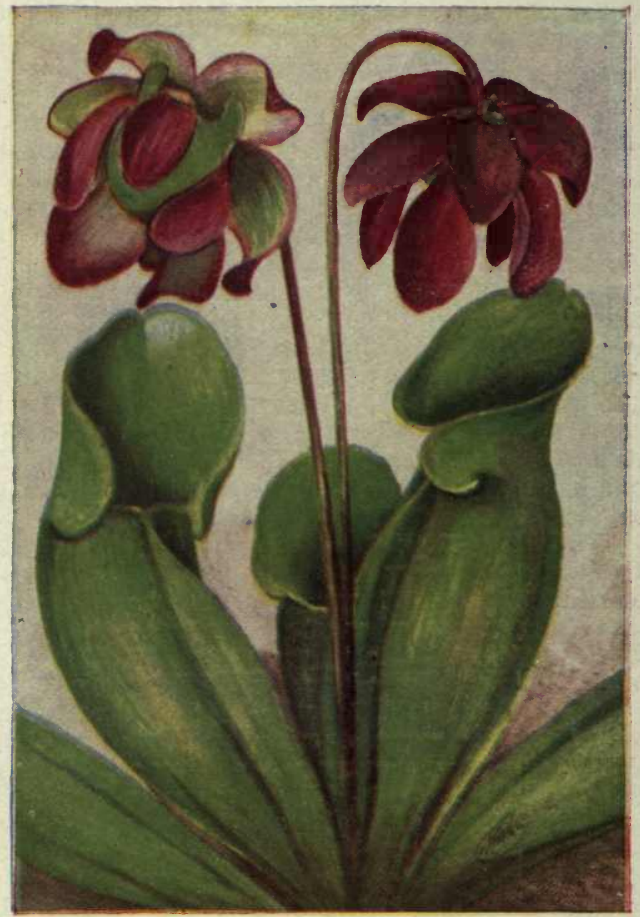

Pitcher Plant.

Sarracenia purpurea. 


\section{PITCHER PLANT FAMILY (Sarraceniaceae)}

A small family of bog-inhabiting plants having hollow pitcher-formed or trumpet-shaped leaves.

\section{PITCHER PLANT; HUNTSMAN'S CUP (Sarracen-} ia purpurea). Few plants are as little known, generally as this species. It is one of the most interesting ones that we have. The shapes of both the leaves and blossoms are clearly shown in the opposite picture. The pitchers, or basal leaves, may number from three to a dozen, all radiating from the root and all with the orifice up. An examination shows that each pitcher is partially filled with water. Just below the rim of the leaf, on the inside, is a sticky substance to attract insects; as these enter, they pass downwards over countless little hairs, all pointing downwards. These make it very difficult for insects to crawl out of the pitcher, and many of them become exhausted and are drowned in the water. As these insects decompose, they are absorbed by the plant. On account of its killing insects and afterwards devouring them by absorption, the Pitcher Plant is often classed as a carnivorous species.

Pitcher Plants grow in boggy places, where Spăgnum Moss abounds; of course such places may become quite dry during the summer. This, however, does not discommode the plant in the least, as it carries its reservoir with it. In cold weather we find the pitchers with the water frozen within them.

No less peculiar is the flower of this plant, a single blossom, borne on a long, hollow, erect scape, during May and June. The five sepals are thick and purplish; the delicate hanging petals are dull pink; the pistil is umbrella-like and surrounded by numerous stamens. The Pitcher Plant is local in bogs from Labrador to Manitoba and southwards. 


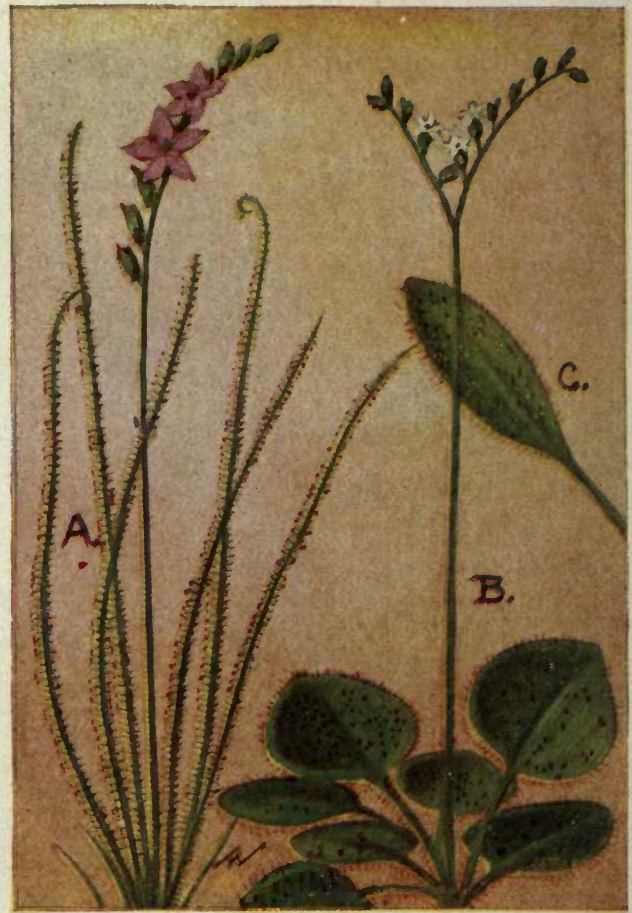
A. Thread-leaved Sundew. Drosera filiformis. B. Round-Leaved Sundew. Drosera rotundifolia. 


\section{Wild Flowers East of the Rockies}

\section{SUNDEW FAMILY (Droseraceae).}

A small family of insectivorous plants found in bogs or moist sandy soil.

THREAD-LEAVED SUNDEW (Drosera filiformis) has long, linear, film-like, erect, very hairy leaves. The flow.ers are numerous and loosely racemed at the top of a slender smooth scape; they have five, small, purple petals, five stamens and several 2-parted stigmas. The flowers open only in the sunshine and bloom towards the top of the scape, where a number of undeveloped buds droop. This species is found in wet sandy soil from New England to Delaware, not far from the coast.

ROUND-LEAVED SUNDEW (Drosera rotundifolia) is one of the most common of the Sundews; it is found in moist, sandy or peaty soil from Labrador to Alaska and south to $\mathrm{Pa}$. and Cal. The leaves are numerous, quite round, and on long stems from the root. The leaves are thickly covered with hairy glands, that exude drops of a clear glutinous fluid, glistening in the sunlight like little drops of dew; it is from these that the plant is named. These dewlike drops deceive insects into alighting on the leaves, when they discover, to their dismay, that they are held fast prisoners in the sticky fluid. Having caught a victim, the leaf slowly folds about it and more slowly digests it.

The flower stalk of this species grows from 5 to 9 in. high, is reddish colored and often has one or two branches at the top. The one to twenty five flowers that it has during the flowering season are white. They open but one or two at a time, and only in bright sunshine. The leaves, and also the short rootstalk, have rather purplish juices that stain what they come in contact with. While they are small and inconspicuous, one will find it well worth while to study these plants. 


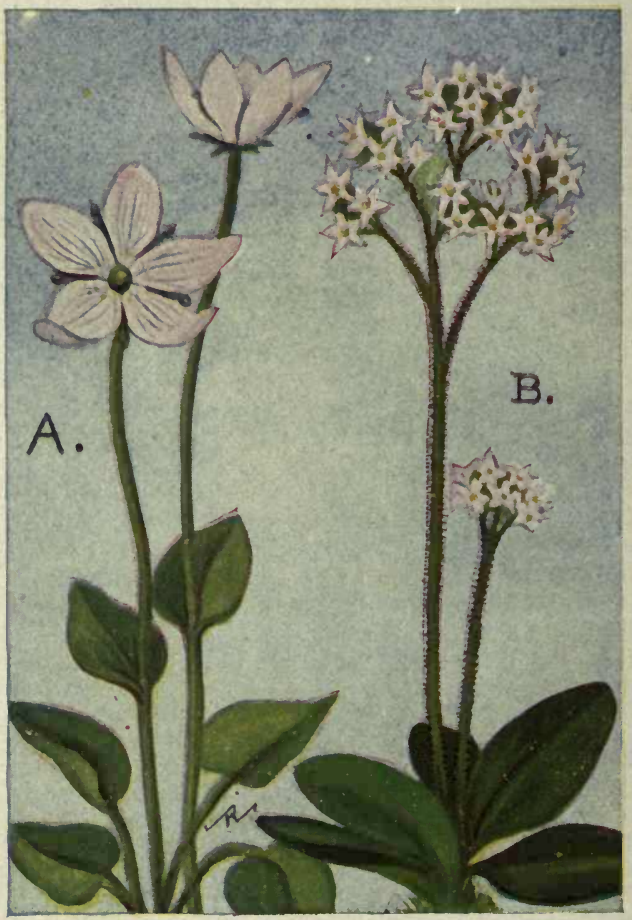

A. Grass of Parnassus.

Parnassia caroliniana.

B. Early Saxifrage.

Saxifraga virginiensis. 


\section{SAXIFRAGE FAMILY (Saxifragaceae).}

Herbs or shrubs having perfect flowers, usually with five petals, and either opposite or alternate leaves: The seeds have copious albumen, which sep arates this family from the various species of the Rose Family.

\section{GRASS OF PARNASSUS (Parnassia caroliniana)} is a pretty little swamp or meadow plant growing from 8 to 24 inches high. The flowers are a delicate creamy white, finely veined with greenish, and borne singly on long scapes; a single, heart-shaped leaf clasps each flower scape a short distance above its base. The basal leaves are long-stemmed, rather thick and coarse in texture, smooth-edged and bluntly pointed.

The flowers present rather an unusual appearance, both because of the veining and because the five fertile stamens alternate with the petals, leaving the yellowish anthers located just at the angle, formed where the petals overlap. We find this species in bloom from the latter part of June until the end of September, most abundantly in the latter month. It ranges from Newfoundland to Manitoba, south to Va. and Mo.

EARLY SAXIFRAGE (Saxifraga virginiensis) is a tiny-flowered plant that loves dry, sunny, rocky hillsides; in these places we may look for its flowers during March and April. The leaves are all basal; spatulate in shape, blunt ended, either rough-edged or toothed, rather coarse in texture, narrowing towards their base into clasping stems. The flower scapes are quite stout, hairy and rather sticky; the white flowers, in loose umbels at the top, are small and five parted. Saxifrage is common from N. B, to Minn, south to Ga. and Tenn. 


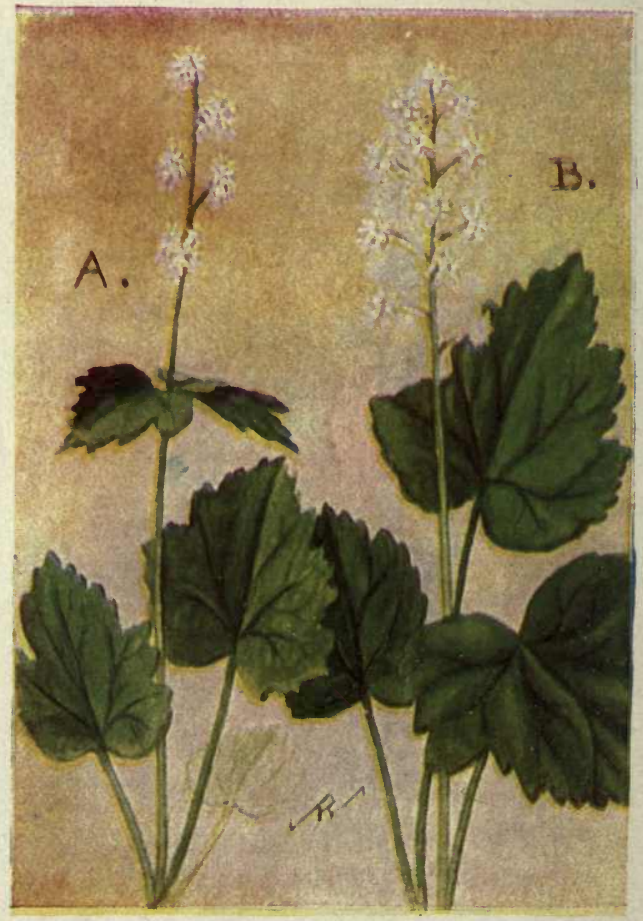

A. Mitrewort.

Mitella diphylla.

B. Foam Flower; False Mitrewort. Tiarella cordifolia. 
MITREWORT (Mitella nuda) is a tiny woodland plant that might readily escape our notice were it not for the peculiar little flowers. These are few in number, very short-stemmed, in a loose raceme at the top of a leafless, slightly hairy scape 4 to 7 in. high. The flowers have five petals, each with the edge beautifully fringed so as to give the flower a crystalline appearance almost like a snowflake. The leaves are on long, hairy stems from the root; they are rounded or kidney-shaped with rough or lobed edges.

These plants are often called "Bishops Caps" from the cap-like shape of the little seed pods. We find this species from Labrador to Saskatchewan, south to $\mathrm{Ct}$. and Mich.

TWO-LEAVED MITREWORT (Mitella diphylla) is a larger and sturdier species with similar flowers, but with two very short-stemmed, heart-shaped leaves clasping the flower stem oppositely about halfway up its length. The stem has more flowers at its top than the last species and is taller, ranging from 8 to 16 inches high. The basal leaves are heart-shaped, with three to five toothed lobes. This species is found in rich woods from N. E. to Minn., south to N. C. and Mo.

FOAM FLOWER; FALSE MITREWORT (Tiarella cordifolia) has the general appearance of the last species. The slender, hairy flower scape, rising 6 to 12 in. from the rootstalk, has at the top a loose panicle of many small flowers, each on a long slender stem, thus differing from the short-stemmed flowers of Mitella. The leaves are all basal, on long hairy stems; heart-shaped, lobed and toothed and often mottled with brownish. The flowers have five petals and ten long stamens that give them a fuzzy appearance. Foam Flower is common from N. S. to Minn., southwards, flowering in May and June. 


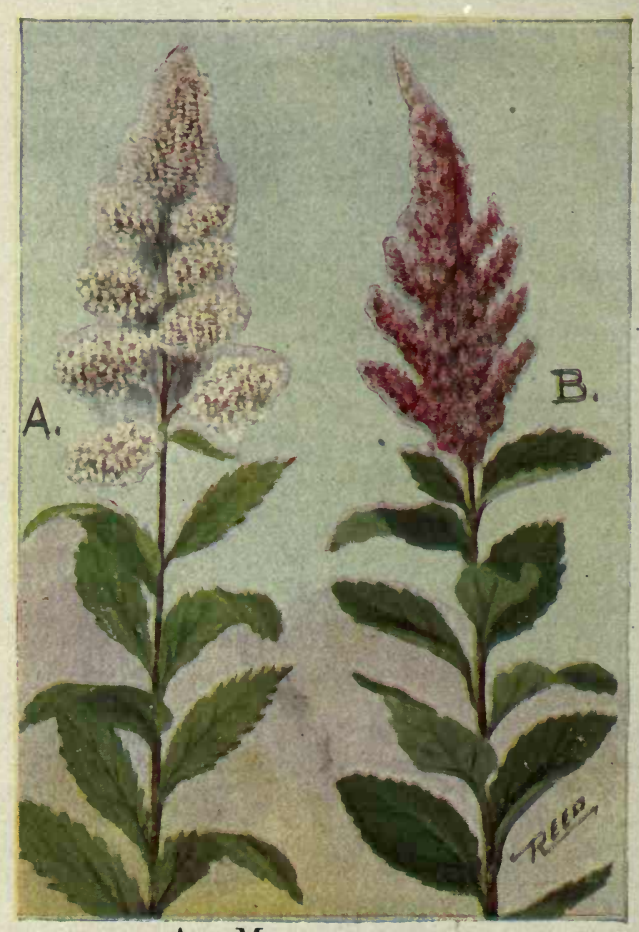

A. Meadowsweet. Spiraea latifolia.

B. Hardack; Steeple Bush. Spiraea tomentosa. 


\section{ROSE FAMILY (Rosaceae).}

This is a very large family made up of trees, shrubs and herbs. It contains some of our most valuable plants and fruit-bearing trees such as pear, apple, strawberry, blackberry, etc. The flowers are all regular, have five petals, five sepals, numerous stamens, one or more pistils, and an abundance of nectar and pollen. They supply a bounteous feast for insects and they are chiefly fertilized by them.

MEADOWSWEET (Spiraea salicifolia) is a common and beautiful shrub that grows along the edges of woods, swamps or even roadsides. Its handsome pyramidal clusters of flowers are in evidence during July and August. The stem is straight, slender, woody and yellowish buff; along it, at close intervals, alternate the lanceolate, toothed, short-stemmed leaves. At the top is a spire-like panicle of fleecy flower clusters. Each flower has five, round, white petals and numerous long, pink stamens that give the flowers a feathery appearance and a rosy tint.

Its name is rather misleading for the flowers are only slightly fragrant. It ranges from N. Y. to Mo. and southwards; the common species found in the New England states is specifically known as latifolia. Its leaves are thinner and the stem more reddish.

HARDHACK; STEEPLEBUSH (Spiraea tomentosa) is one of our most beautiful flowering shrubs. The flower spike is more slender and steeple-like than that of Meadowsweet and the flowers are a beautiful shade of pink. The flowers bloom downwards from the top of the spike, so that it soon assumes a brownish or yellowish tinge at the top of the spire. The leaves are more closely alternated and are dark green above and lighter below. Steeplebush grows in low ground from N. B. to Minn. and sulithwards. 


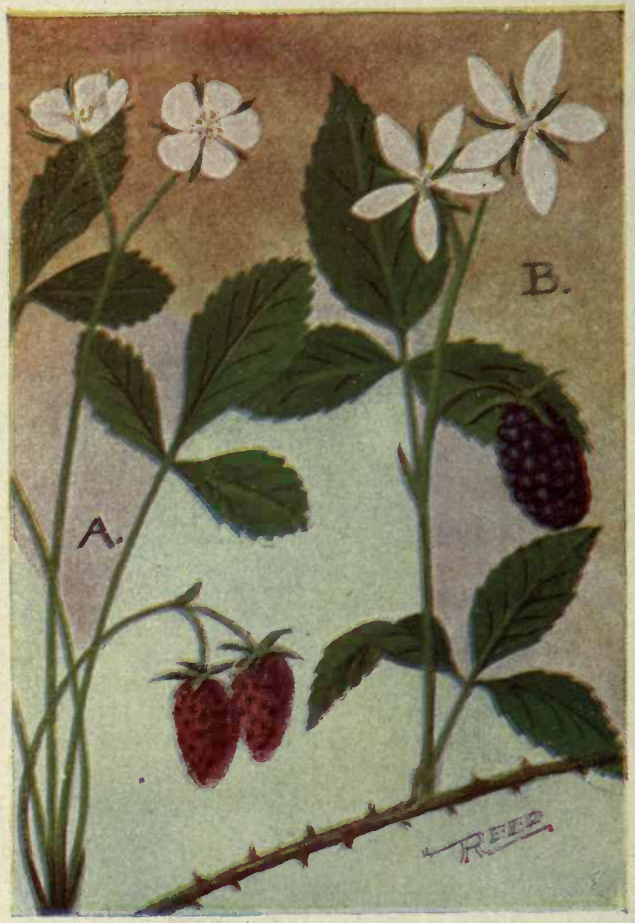

A. Wild Strawberry.

Fragraria virginiana.

B. Wild Blackberry.

Rubus allegheniensis. 


\section{Wild Flowers East of the Rockies}

WILD STRAWBERRY (Fragraria virginiana). Anyone not acquainted with the Strawberry in its wild state has our sympathy for they have missed one of the most luscious treats that Nature has provided. We have, after years of cultivation, increased the size of the berry many times, it is true, but this increase in size has been largely at the expense of deterioration in flavor. I have yet to see the cultivated strawberry that is comparable to the wild one in this respect.

The hairy stems of both leaves and flowers rise directly from the running rootstalk. The flowers, several of which grow on each stem, are wheel-shaped, have five rounded white petals and narrow lanceolate greenish sepals; the center is occupied by a green cone-like pistil and numerous stamens with small yellow anthers. After the flowering season, the green center expands, becomes pulpy and finally turns red on the outer surface; the numerous seeds are in little pits provided for them on the surface of the berry. The weight of the berries causes the slender peduncles to bend, while the flowers were erect.

The leaves are three-parted, each division being spatulate and sharply toothed at the rounded end. The Wild Strawberry is common in fields and pastures throughout our range.

.. HIGH BUSH BLACKBERRY (Rubus allegheniensis) is a tall branching shrub with slender brown stems, from three to ten feet long, armed with stout, slightly recurved prickles. It is from this species that the well known variety was developed. The leaves are divided into three to five ovate, pointed, toothed leaflets with a ribbed and hairy surface. The flowers have five green sepals alternating with the narrow white petals. This species is common everywhere. 


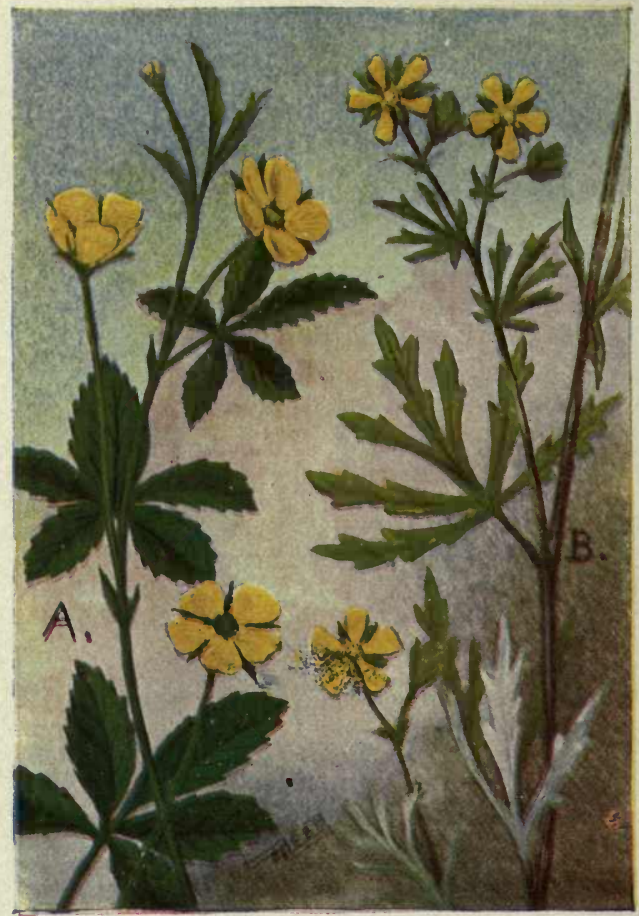

A. Common Cinquefoil; Five-finger. Potentilla simplex.

B. Silvery Cinquefoil. Potentilla argentea. 
COMMON CINQUEFOIL; FIVE-FINGER (Potentilla canadensis). This species is the most common of the Five-fingers, and is also one of our most common wild flowers, in pastures and along roadsides. It has a long period of bloom and flowers may be found from April until August. It is often mistaken for the Wild Strawberry, because of a similarity between the leaves of the two species, although those of this species have five divisions while those of the Strawberry have but three. The flowers are shaped like those of the Strawberry, but have bright yellow petals.

The flowers are solitary, on long, slender stems from the axils of the leaves near the ends of the trailing branches, that grow from 6 to 24 inches long. This species is very common in the United States and southern Canada.

SILVERY CINQUEFOIL (Potentilla argentea) is a common and very handsome species found in dry, barren ground throughout our range, but most abundantly near the coast. It is smaller than the proceeding, being from 5 to $12 \mathrm{in}$. high. The little, yellow flowers are clustered at the ends of the branches. The stems and the undersides of the divided and deeply cut leaves, are covered with fine, white, silvery wool, contrasting sharply with the dark green of the upper surfaces. This species bloom from May until September.

SHRUBBY CINQUEFOIL (Potentilla fructicosa) is a very leafy and much branched Cinquefoil growing from six inches to three feet high. The leaves are divided into five to seven narrow leaflets, with a smooth but usually rolled edge; they are lighter below but not wooly as in the last species. The stem is quite erect, brownish and with bark often peeling off in shreds. The yellow flowers may be solitary, but usually are in rather flat-topped clusters. This species is common everywhere. 


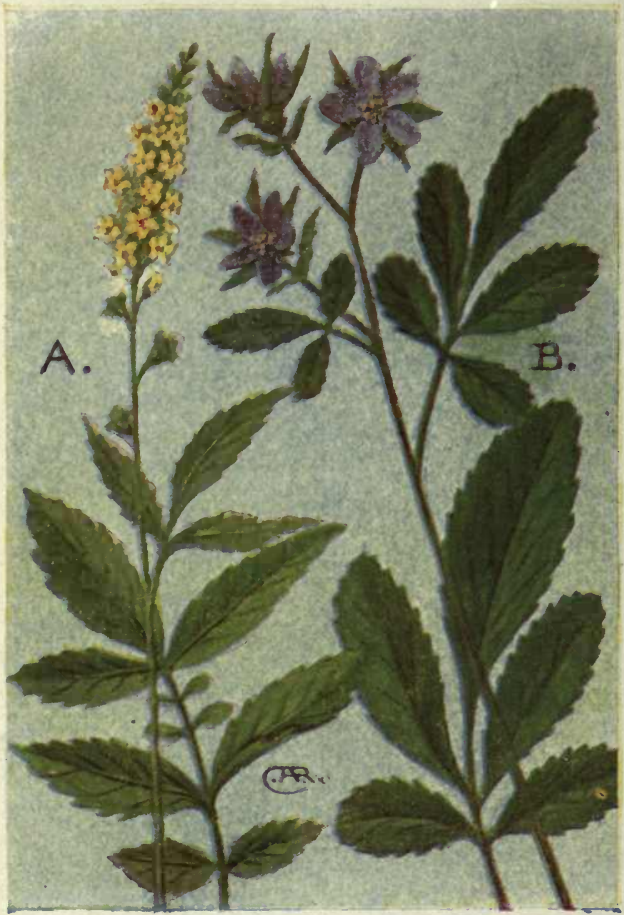

A. Agrimony.

Agrimonia gryposepala.

B. Purple Cinquefoil; Marsh Five-finger. Potentilla palustris. 
MARSH FIVE-FINGER; PURPLE CINQUEFOIL (Potentilla palustris) is in character quite like the foregoing species. It is the only one, however, having purple flowers, and is easily recognized on that account. The flowers are nearly an inch broad, larger than those of the other Cinquefoils; they have a large calyx, the divisions of which are longer than the petals; the petals are also pointed, whereas those of the other species are rounded or else wedge-shaped.

The stem grows from 6 to 20 inches long and is rather woody at the base. The leaves alternate along the stem, as is customary with all members of the Rose family; they are divided into five or seven, spatulate-shaped, toothed leaflets. Purple Cinquefoil grows in swamps or cool bogs, from Labrador to Alaska and south to N. J., Pa., Ia., and Cal., flowering during July and August.

AGRIMONY (Agrimonia gryposepala) is a common weed found on the borders of swamps or thickets. It has a tall, hairy, simple stem from two to four feet high. The bright green leaves are variously compounded, from three small leaflets at the top of the stem to large leaves made up of seven, lanceshaped, toothed leaflets, interspersed with smaller ones on the lower part of the stalk.

The flowers are in a long, many-flowered spike at the top of the stalk. Each flower is tiny, has five yellow petals and numerous, orange stamens, giving the spike a bright, golden-yellow appearance. They open from the bottom of the spike, towards the top, and each plant is in bloom for a long period Our ancestors used the leaves for various medicinal concoctions, and some even used them for making tea. It is a common plant from N. B. to N. C. and westwards to Cal. 


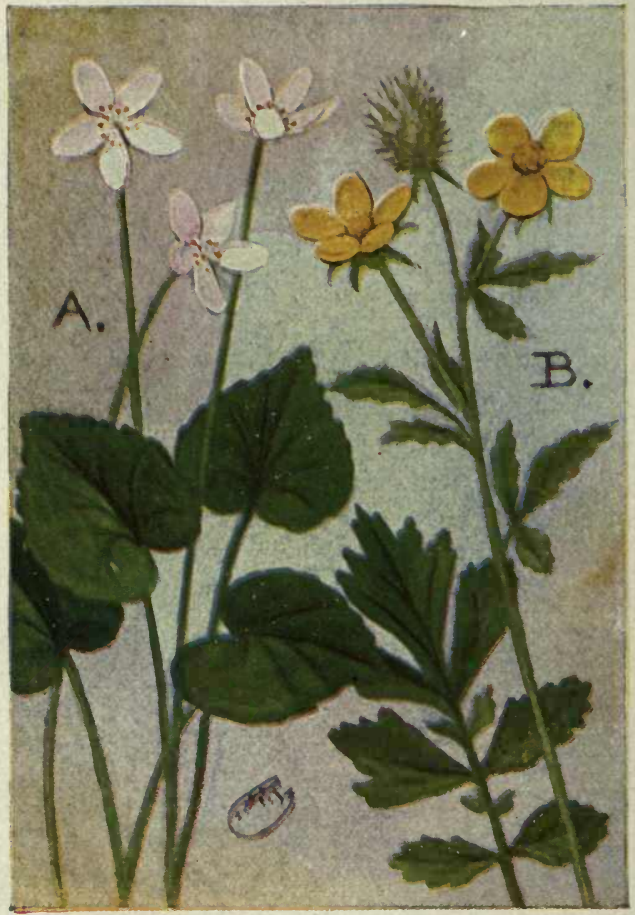

A. Creeping Dalibarda.

Dalibarda repens.

B. Yellow Avens.

Geum strictum. 
CREEPING DALIBARDA (Dalibarda repens) is a delicate woodland plant, found from N. B. to Manitoba and south to N. J., Ohio and Mich. It has creeping, densely-tufted rootstalks, from which spring numerous heart-shaped leaves on long petioles; these leaves, their stems and the flower stalks are downy, the former being scallop-edged or toothed.

Dalibarda has two kinds of flowers: The first on long, upright scapes spread about half an inch, have five oval, white petals and many stamens; the petals are deciduous, faling off soon after the flower opens. The second kind of flowers are cleistogamous ones (fertilized in the bud) on short curving peduncles from the root. These last flowers are fertile, while many of those with petals are not. Dalibarda blooms from June to September in rich woods; when not in flower, its leaves are often mistaken for those of some of the violets.

YELLOW AVENS (Geum strictum) grows in moist locations in swamps or thickets. The texture of the whole plant, leaves and stems, is rough and coarse. The root leaves are interruptedly pinnate, the segments being wedge-shaped and toothed; the stem leaves have three to five oblong, acute, toothed leaflets. The flowers have quite large golden-yellow petals and a downy receptacle. This species is common from Newfoundland to Manitoba and south to N. C. and Mo.

PURPLE AVENS (Geum rivale) is an aquatic or marsh species with lyre-shaped root leaves and few, 3 -lobed stem leaves. The nodding flowers have rusty-purple petals terminating in a claw; the calyx is purplish and bell-shaped. The flower stalk is from one to two feet in height. Purple or Water Avens is common in northern U. S. and southern Canada. 


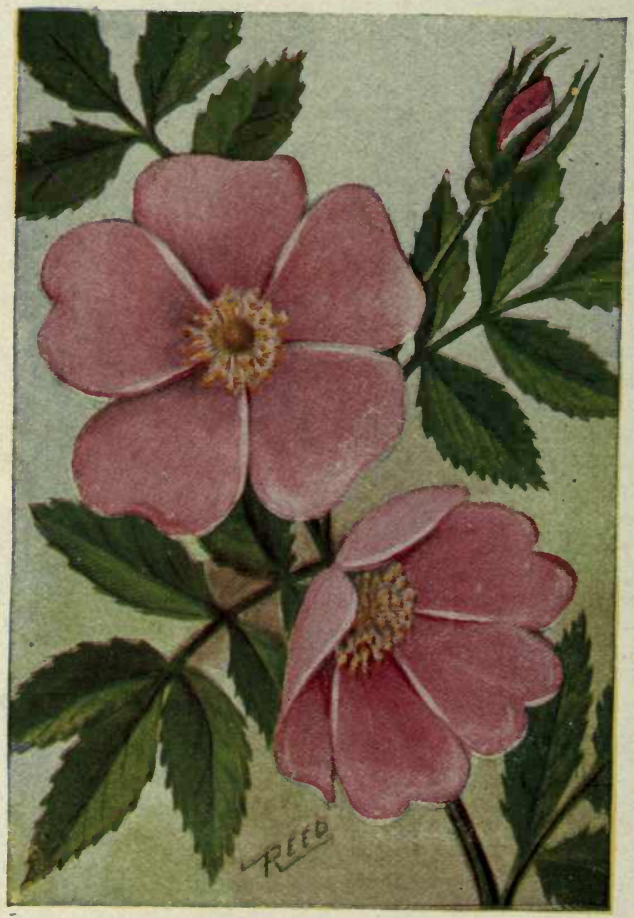

Wild Swamp Rose.

Rosa carolina. 


\section{Wild.Flowers East of the Rockies}

SWAMP ROSE (Rosa carolina). Wild roses are very common throughout our range and, of course, are familiar to everyone. They are usually, and rightly regarded as one of our most beautiful wild flowers. They have a purity of form and color that is rarely seen in the many varieties that man has cultivated from them. The Swamp Rose is a very bushy species, growing from one to nine feet high. It is very common on the edges of swamps or streams, and in low ground, throughout our range. The compound leaf is made up of five to nine, lance-shaped, toothed leaflets; each leaf has a pair of stipules, or tiny leaves, at the junction of the slender stem with main stalk.

The flowers are two or three inches broad and have numerous yellow stamens radiating from the greenish-white center. The stem of the Swamp Rose is sparingly armed with stout, wide-based, curved thorns.

PASTURE ROSE (Rosa humilis) is the most abundant of all our wild roses and grows in profusion in all dry, rocky places. It does not grow as high as the Swamp Rose, rarely exceeding three feet in height, but the slender stems are more branching and often grow in large, tangled masses that, in the height of the blooming season, are exceedingly beautiful. The flowers are about the same size as those of the Swamp Rose, but are usually solitary at the ends of the branches.

The leaves are dark green, without gloss, divided into five or seven ovate, sharply-pointed, irregularly-toothed leaflets. The stem is armed with straight, slender, light brown thorns or prickles, two of which are set oppositely on the stem at its junctions with the leaf stems. These sharp thorns often discourage plucking wild roses, and the petals soon fall or are broken off, so that they are little used for vases. 


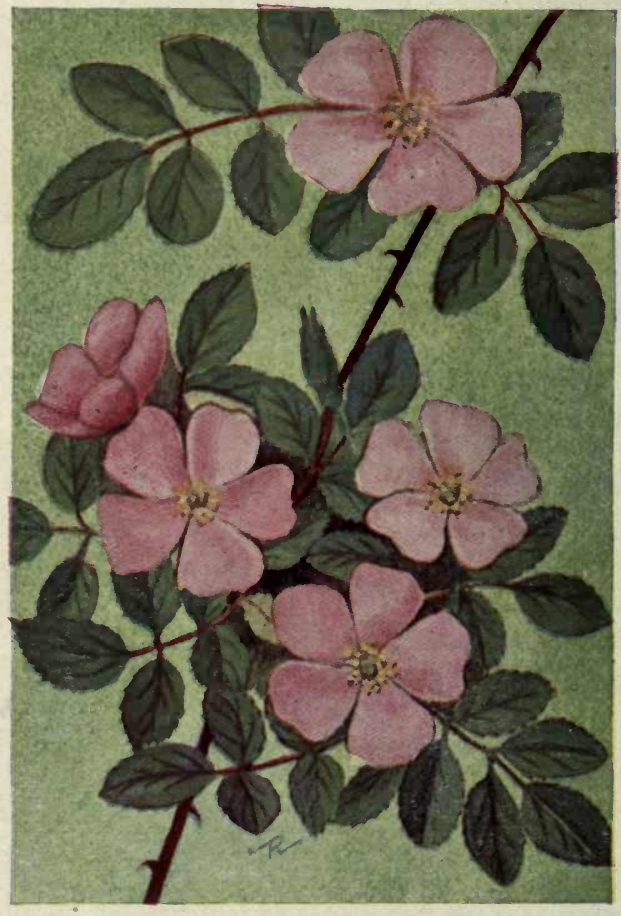

Sweetbrier; Eglantine. Rosa rubiginosa. 
SWEETBRIER; EGLANTINE (Rosa rubiginosa) is a very beautiful species of wild rose introduced from Europe. We may find it blooming quite commonly in dry, rocky pastures and waste places during June and July. It is remarkable for and easily identified by, the sweet-scented, aromatic fragrance of its leaves. The stems are long and arching, growing from two to six feet in height; they are brown and are armed at frequent intervals with short, decidedly recurved thorns or prickles.

At regular intervals along the stem, are close-set, compact clusters of flowers and leaves. The leaves are made up of five or seven very small leaflets, rounded-ovate in form and with the edge finely double-toothed, and covered beneath with fine, sticky, glandular hairs. The flowers are also quite small, especially when compared to the very common Pasture and Swamp Roses, being only from one to two inches in diameter. They are rather light colored, a creamy-pink, and have five, heart-shaped petals, the ends being slightly notched; the numerous, curving stamens are a bright yellow. All of the roses have quite large fruit, red in color and with the ends of the sepals spreading from its apex; that of the present species is ovoid in shape. Eglantine is found from Nova Scotia to Michigan and southwards to Virginia and Tenn.

SMOOTH ROSE (Rosa blanda) is a species that is often wholly unarmed with prickles. The stem and the underside of the leaves are covered with a light bloom. The pale crimson-pink flowers measure nearly three inches across. The red fruit is either round or pear-shaped, with persistent sepals.

The Smooth Rose has a very northerly distribution. It is found in rocky places from Newfoundland and nothern New England westwards, chiefly along the shores of the Great Lakes. 


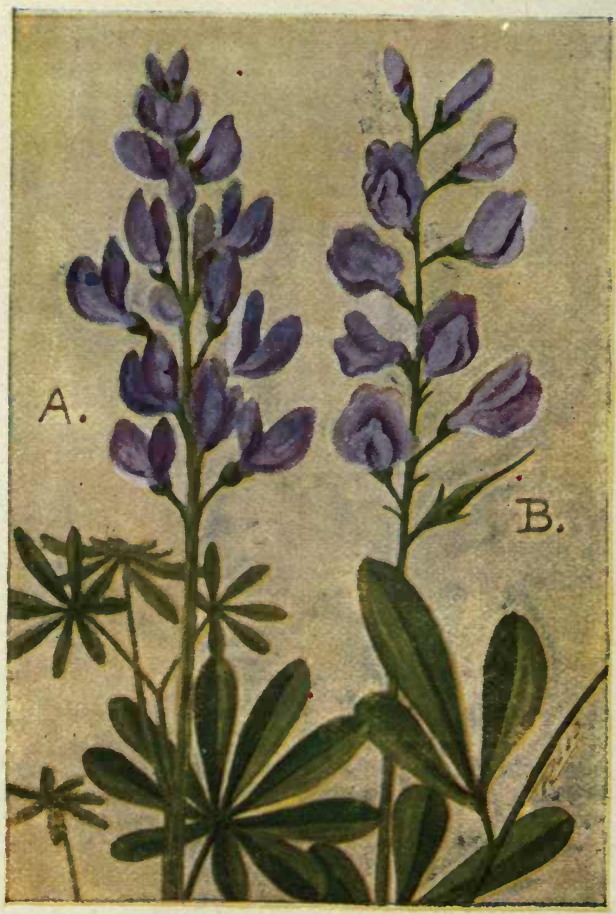

A. Wild Lupine.

Lupinus perennis.

B. Blue False Indigo.

Baptisia australis. 


\section{PULSE FAMILY (Leguminosae).}

A very large and valuable family of plants, many of them being food-producing. Usually they have papilionaceous flowers, that is, with a standard, keel and wings. The family is divided into three subfamilies containing 53 genera.

WILD OR BLUE LUPINE (Lupinus perennis) receives its generic name from the Latin of wolf, because it was thought that the species preyed upon the soil and made it infertile for other kinds of plants. It is a very common species in sandy places and we often see it on the banks along railroads. Both the leaves and the flowers are very attractive. The stem is quite stout, erect, hairy and hranching. The leaves have long, slender stems; the leaf, proper, is palmately-divided into seven to eleven narrow, smooth-edged leaflets that radiate like the spokes of a wheel; they are rather thin and delicate in structure and at night partly fold together.

The flowers are in long, showy, terminal spikes of pea-like blossoms; they are bright purplish- blue in color; the calyx is two-lipped, sides of the standard reflexed and the keel scythe-shaped. The single pistil developes into an oblong, flattened, knotty pod containing the seeds. Lupine is very common through the United States, east of the Rocky Mountains.

BLUE FALSE INDIGO (Baptisia australis) is a tall branching species with a stem from three to six feet in height. The leaves are divided into three spatulate-shaped leaflets. The violet-blue flowers grow in long, loose spikes; they are about one inch long, have a four or five-toothed calyx, straight keel and wings, and short standard. The seed-pod has a spur at its tip. This species is common from $\mathrm{Pa}$. to $\mathrm{Ga}$. and west to Mo. 


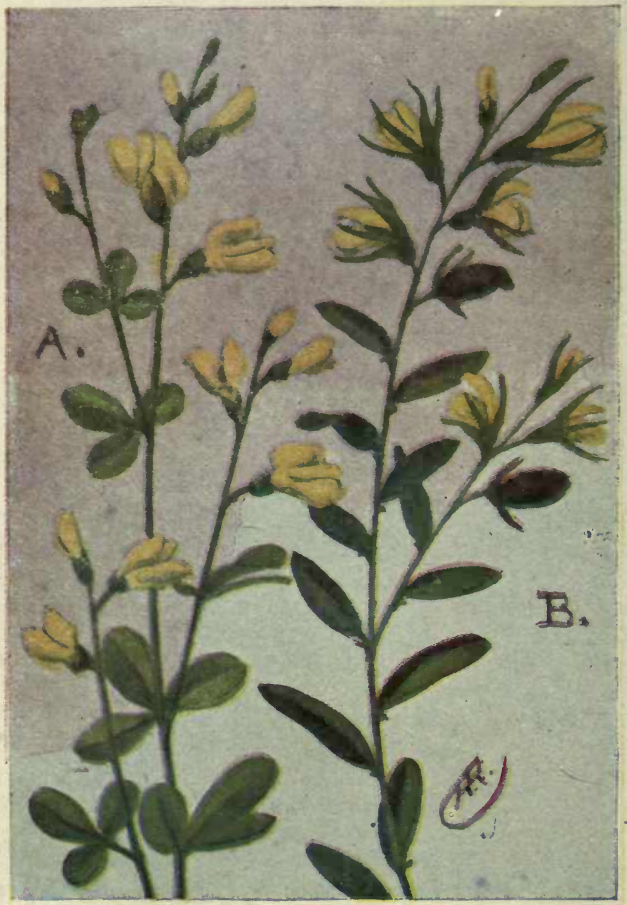

A. Wild Indigo.

Baptisia tinctoria.

B. Rattlebox.

Crotalaria sagittalis. 


\section{Wild Flowers East of the Rockies}

WILD INDIGO (Baptisia tinctoria) is a very branchy and very bushy herb. The stem divides soon after it leaves the ground, the slender branchlets extending equally in all directions so that the appearance of the whole plant, from a distance, is often that of a large, bluish-green globe. The leaves are three-parted, wedge-shaped, dull green with a white bloom that gives them a bluish-green appearance. The yellow, butterfly-shaped flowers are in loose clusters at the ends of all the branches. They are visited by many of the small butterflies and small bees. After fertilization, the flowers turn blackish.

The roots of Wild Indigo are used by drug concerns for the compounding of a number of medicines. An indigo dye, of a poor quality, can also be made from the plant. Wild Indigo grows in dry or sandy soil from Maine to Minnesota, flowering from June to September.

RATTLEBOX (Crotalaria sagittalis) receives its name because the seeds rattle about in the large, inflated, blackish, seed-pod. It is an annual herb, with a hairy, bending stem and stemless, toothless, pointed-oval leaves alternating along it. The yellow, pea-like flowers are in small clusters at the ends of the branches. It is found in sandy soil, chiefly along the coast, from Mass. to Fla. and Texas and, in the Mississippi basin, to Indiana and South Dakota.

PRAIRIE CLOVER (Petalostemum purpureum) is an upright perennial herb, with the smooth stem crowded with leaves, compounded of five, narrowlylinear leaflets. The flowers are small and crowded in dense terminal spikes; they are purple or rose- colored, have a small standard and four petals on threadlike claws. It is found on dry prairies west of the Mississippi. 


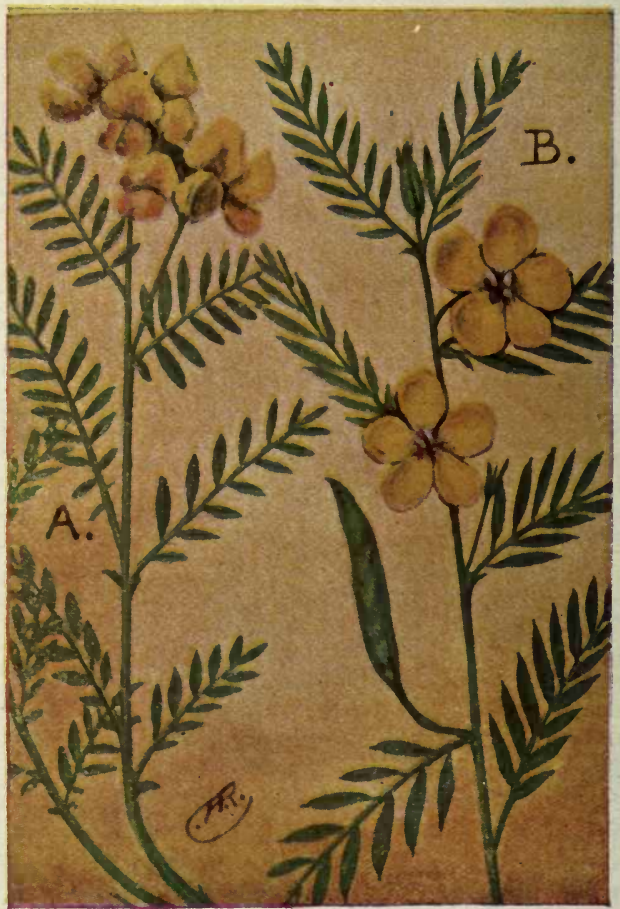

A. Goat's Rue; Catgut.

Tephrosia virginiana.

B. Partridge Pea.

Cassia Chamaecrista. 
GOATS RUE; CAT GUT (Tephrosia virginiana). We find this herb in most all dry, sandy, waste places from N. H. to Minn. and southwards.

It is a pea-like plant with a simple, silky-haired, erect stem, leafy to the top where it terminates in a dense raceme or panicle of yellowish-white flowers marked with purple. The flowers are large and numerous; they have a rounded standard, but little longer than the wings and keel. The long leaves are compounded of seventeen to twenty-nine linear-oblong leaflets. Its roots are long, very slender and very tough; it is from these qualities of the roots that the plant receives its common names.

PARTRIDGE PEA (Cassia Chamaecrista) is a handsome species with large, showy, yellow flowers measuring about 1 1-4 inches across; on slender pedicels from the angles of the leaves, usually either singly or in pairs; often the five, large, rounded petals have purplish spots at their bases; after flowering, long erect seed pods are left in the place of each of the blossoms.

The leaves of the Partridge Pea are long and compounded of 20-30 small, blunt, lance-shaped leaflets, each with a tiny awl-like point. The stem is erect, rather smooth, and grows one or two feet tall. We find this plant in dry or sandy fields throughout the United States.

WILD SENSITIVE PLANT (Cassia nictitans) is quite similar but much taller. The flowers are small and on short stems, in groups of two or three at the bases of the leaves. The leaves are compounded of 10-20 small leaflets, less than 3-4 inches long; they are very sensitive and close, or fold together, at night, or in the daytime if handled roughly. It is found from Me. to Fla. and west to Nebr. and Tex. 


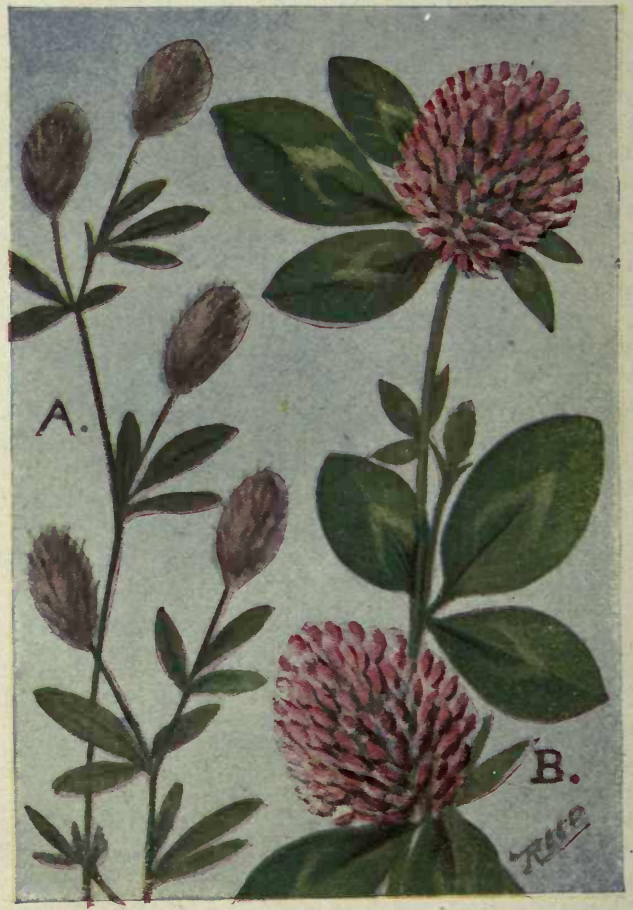

A. Rabitifoot Clover; Stone Clover. Trifolium arvense. B. Red Clover. Trifolium pratense. 
RABBIT-FOOT CLOVER; STONE CLOVER (Trifolium arvense) (EUROPEAN). It is not always the largest, brightest colored and showiest flowers that are the most beautiful; the present species has a graceful, charming, silky beauty that places it far in advance of many of its brighter colored companions in the field. Yet, how often are its fuzzy heads passed by as weeds unworthy of notice. It is because of this silky, fuzziness that it receives its name of Rabbit-foot, and from the fact that it often grows in stony or rocky fields that it has been given its second name.

The stalk of this species is soft, silky and from 4 to 10 inches high. The light green leaves have three leaflets with blunt tips. The flower heads are composed of numerous florets; it is the long, pink, feathery tips of the five-parted calyx that gives the blossom its silky fuzziness; it is quite fragrant and is visited by the smallest butterflies. You may find this species everywhere within our range.

RED CLOVER (Trifolium pratense) is the most common and the most valuable species of clover. One would hardly believe, knowing how abundant it is in all parts of our range, that this clover could have been introduced and have become so widely distributed, yet such is the case. One reason that it does so well in this country is that we have a very large number of bumblebees, and it has been found that clover is so dependent upon these insects for fertilization, that, without them, it will soon die out.

The little florets, composing the globular flowerhead, are bright crimson-pink; they abound in nectar and are sweet-scented. The three leaflets that make up each leaf, have whitish-green triangles in the middle. The plant stems are hairy and from 8 to 24 inches high. 


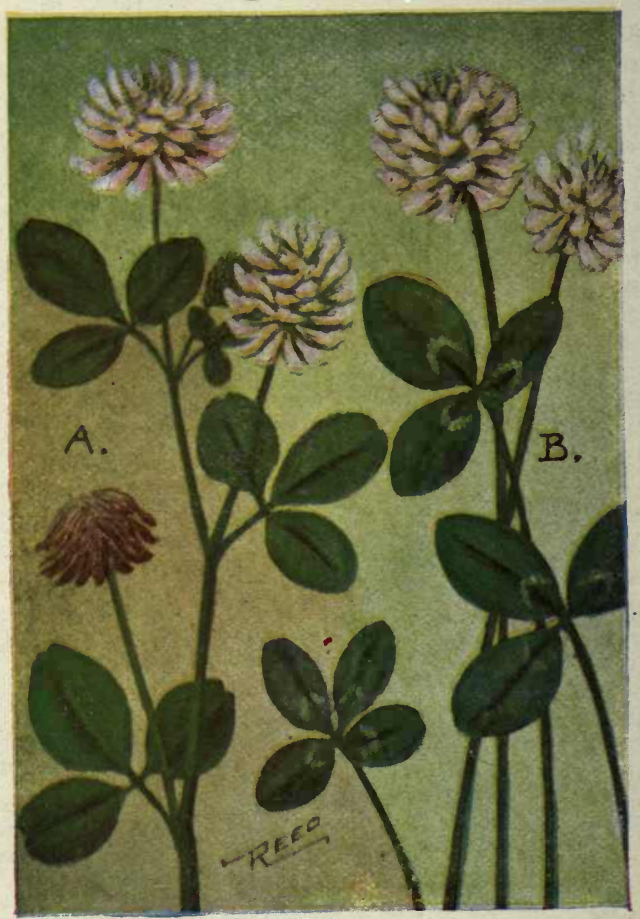

A. Alsike Clover.

Trifolium hybridum.

B. White Clover.

Trifolium repens. 
ALSIKE or ALSATIAN CLOVER (Trifolium hybridum) (EUROPEAN) is quite similar to our native white Clover, but the stem is stout, branching and juicy. The trifoliate leaves of this species are unmarked and have a simple, rounded end, not notched, but the edge of the leaf is very finely toothed; they have long slender stems, with stipules where they join the stalk. The florets composing the round flower-heads are cream-colored, tinged with pink; they are very fragrant and laden with nectar. The lower florets on the head bloom first; after they have been fertilized, they turn brown, and are reflexed, so that towards the end of the flowering season, the flowers have a very disheveled appearance, the lower part being dead and drooping, while the upper is fresh, pink and erect.

This species is now common throughout our range, flowering from May to October in meadows, waste places or along roadsides.

WHITE CLOVER (Trifolium repens) is the most common of the white clovers. It is supposed to be indigenous in the northern parts of our range. It is highly prized as forage for cattle and is often cultivated in fields for that purpose. It is also a favorite with keepers of bees, for it is very rich in nectar and they claim that it makes a better quality of honey than any other.

Its stems are smooth, reclining and 4 to 10 inches long; they creep by runners. The leaves are composed of three leaflets, heart-shaped or notched at the ends, and usually with a more or less distinct triangular mark in the middle. This is the species that furnishes the prized "4-leaved clovers" that children so dearly love to find, and that are supposed to signify "good luck". The flowers are creamy white, slightly pinkish and very fragrant. 


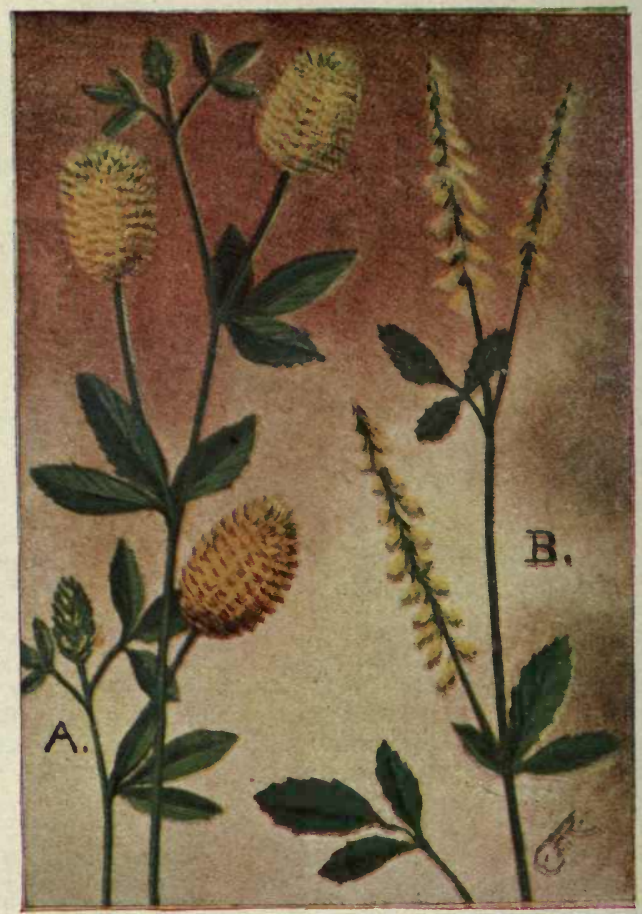
A. Yellow Clover; Hop Clover. Trifolium agrarium.
B. Yellow Melilot; Sweet Clover. Melilotus officinalis. 
Wild Flowers East of the Rockies.

YELLOW CLOVER; HOP CLOVER (Trifolium agrarium) (EUROPEAN). This clover, that came to our shores, long ago, from across the water, is very common in the eastern half of the United States and southern Canada; we find it growing most abundantly along roadsides and in dry or sandy fields.

The stem is quite smooth, slender, erect and slightly branching and grows from 6 to 15 inches high. The leaves have very short stems, in fact they are practically seated on the stalk; the lower ones have large stipules at their bases; they are thin and soft and have fine, feather-veining on each of the three small leaflets making up the leaf.

The flowers grow singly, or in clusters of two or three, at the ends of the branches. The flower head is oblong, densely crowded with small, golden-yellow florets, having an alternate, scaly arrangement. They bloom from the bottom of the head, upwards and, as they mature, turn yellowish-brown and are reflexed, resembling dried hops. Several stalks may spring from a single root, so that the plant sometimes has quite a bushy appearance. Its flowering season is from June until September.

LOW HOP CLOVER (Trifolium procumbens) (EU! ROPEAN) is a very similar species with a low, spreading, brancining stem and with the three leaflets, notched at the ends and the middle one with a short stem. It is a common species throughout our range.

YELLOW MELILOT; YELLOW SWEET CLOVER (Melilotus officinalis) (EUROPEAN) is a common, weed-like plant found everywhere in waste places. The stem is tall and branching, growing from 2 to 4 feet high. The leaves are trifoliate, each leaflet being finely toothed and the middle one having a short stem with a double bend. The yellow, clover-like florets are in long, loose racemes, terminating the branches; they have a sweet fragrance. 


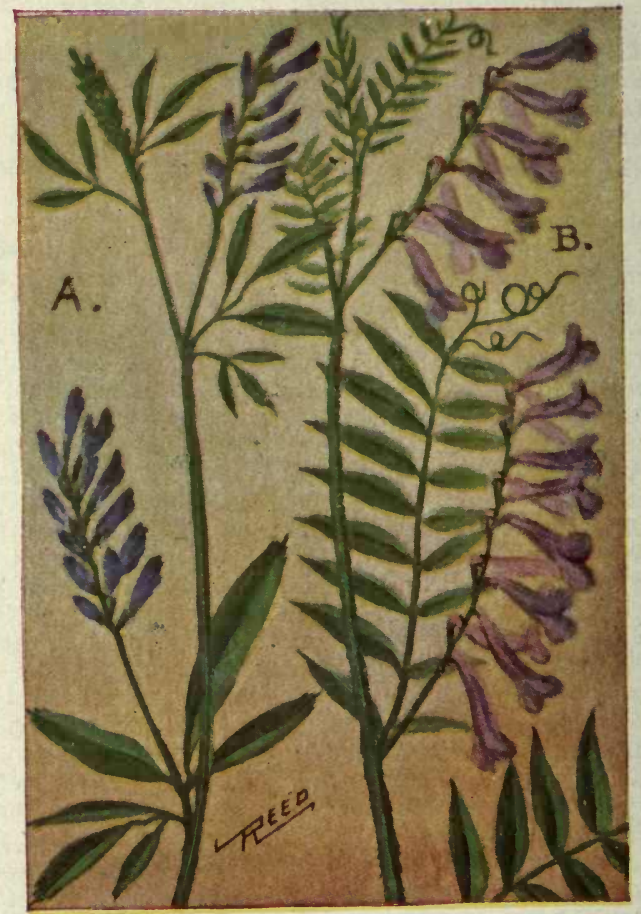

A. Alfalfa; Lucerne.

Medicago sativa.

B. Cow Vetch.

Vicia Cracca. 
ALFALFA; LUCERNE (Medicago sativa) (EUROPEAN) is found growing wild in waste places or fields most anywhere in our range. It makes an excellent fodder for cattle and will grow in waste, sandy places where it is impossible to raise crops of hay.

Our Government has devoted considerable attention to the cultivation of this species and it is now extensively raised in the Southern and Western States, where thousands of tons are annually harvested and stored for the needs of livestock.

The stalk is smooth, slender, branching and erect; it grows from 1 to 2 feet high. The leaves are threeparted, on long slender stems with narrow stipules at their bases; each of the three leaflets has a tiny, sharp bristle at its end, and the middle one has a short, slender stem with a distinct double bend. The purple flowers grow in short, loose racemes at the ends of the slender branches; the seed-pod is curiously twisted or coiled and contains several seeds.

COW VETCH; BLUE VETCH (Vicia Cracca) is a trailing herb with a weak, angled stem; it is common on the borders of thickets or the edges of cultivated fields. The stem grows from two to three feet long and climbs over grass or low brush by means of small, slender tendrils at the ends of the leaves.

The compound leaves are made up of twenty to thirty small, oval leaflets, each tipped with a tiny, sharp-pointed bristle. The light violet-colored, beanlike flowers grow in a one-sided raceme on slender stalks from the angles of the terminating leaves of the branching, hairy stem. The flowers are reflexed, that is, they point downwards on their stem.

Several other species of Vetch have been introduced and are quite common, chief of which is the Common Vetch (V. sativa) which has fewer leaflets and flowers in pairs. 


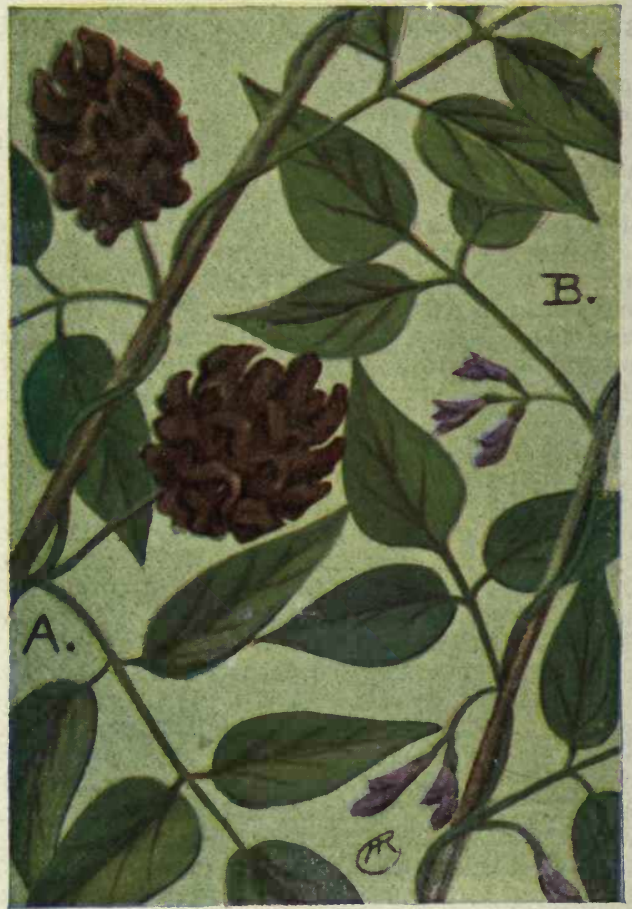

A. Ground Nut; Wild Bean. Apios tuberosa. B. Hog Peanut. Amphicarpa monoica. 
GROUND NUT; WILD BEAN (Apios tuberosa) is an exceedingly beautiful climbing vine, attaining lengths of four or five feet, crawling over walls or fences, or twisting itself about shrubs or other plants. Its pear-shaped, tuberous root is edible, as every country boy knows.

While it does not prey upon plants by sucking their juices, as some of the climbing, twining vines do, this species sometimes entwines itself so tightly about its supporting plant as to retard the latter's growth or even to kill it. One of the most unique floral sights, that I recall, is that of many large Tiger Lilies, with their tall stout stalks entwined with the present species, and each of them in full flower.

The leaves of the Ground Nut are compounded of five, or sometimes seven, ovate-pointed leaflets; they are toothless, smooth and light green. The flowers grow in dense, rounded clusters on slender stalks from between the angles of the leaves and the plant stem; they are maroon or lilac-brown, have very broad, reflexed standards and long scythe-shaped keels, strongly incurved or coiled. The flowers have a very rich coloring, different from that of any other species that I have ever seen. We find the Ground Nut in bloom during August and September in damp ground, usually on the borders of swamps or wet meadows, from N. B. to Minn. and southwards to the Gulf.

WILD or HOG PEANUT (Amphicarpa monoica) is a dainty, trailing vine 2 to 7 feet long. The delicate, light green leaves are thrice compounded, on slender stems from the angles of which are small, drooping clusters of magenta-lilac blossoms. Other fruitful blossoms at the base of the plant develop into pearshaped pods with single large seeds. From the fact that hogs used to root up and eat these, came the rather inappropriate name. 


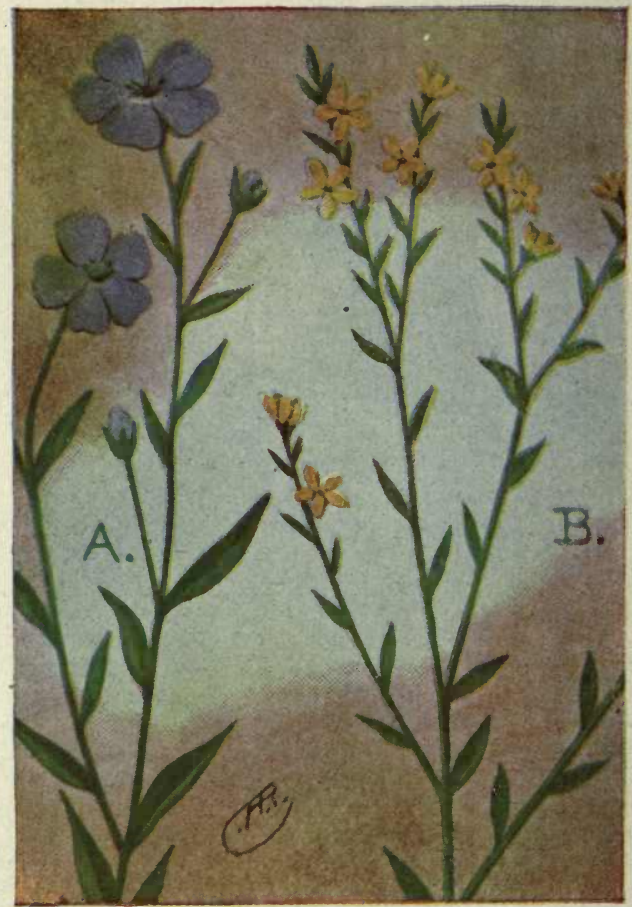

A. Common Flax.

Linum usitatissimum.

B. Yellow Flax.

Linum virginianum. 


\section{Wild Flowers East of the Rockies}

\section{FLAX FAMILY (Linaceae).}

A small family of slender herbs; very valuable, as they furnish the flax from which all linen is made and many valuable medicinal remedies.

WILD YELLOW FLAX (Linum virginianum) is a slender perennial species with a smooth stem from one to two feet in height; it branches slightly near the summit, each branch bearing at its end a few tiny yellow flowers, less than a half inch across. The flowers have a calyx divided into five sepals, a corolla of five petals, five stamens and pistils, perfect and symmetrical flowers fertilized by small bees and beelike flies. The small leaves are thin and have but one rib. This species may be found in dry woodland and thickets from Me. to Minn. and southwards to Ga.

COMMON FLAX (Linum usutatissimum) (EUROPEAN). This slender species is more attractive than the last because of its larger flowers. The stem is very slender, from one to two feet in height, and each of its few branches are terminated with one or two delicate, violet-blue flowers; these measure about three quarters of an inch broad, or slightly more, the five petals being large, broad and slightly over-lapping. Small, alternate, sharp-pointed leaves are thickly crowded on the stem; they have three, longitudinal ribs.

This is the species that is cultivated very extensively in Europe, and less so in this country, for its linen fibre and its seed oil, both of which have a very extensive commercial use. It may be found along roadsides or railroads or in waste places anywhere, usually as an escape from cultivation.

Linum striatum has tiny yellow flowers crowded on the stiff, angular branches. The leaves grow oppositely. It is found in wet woods or on sandy shores from Mass. to Ga. and west to Tex. 


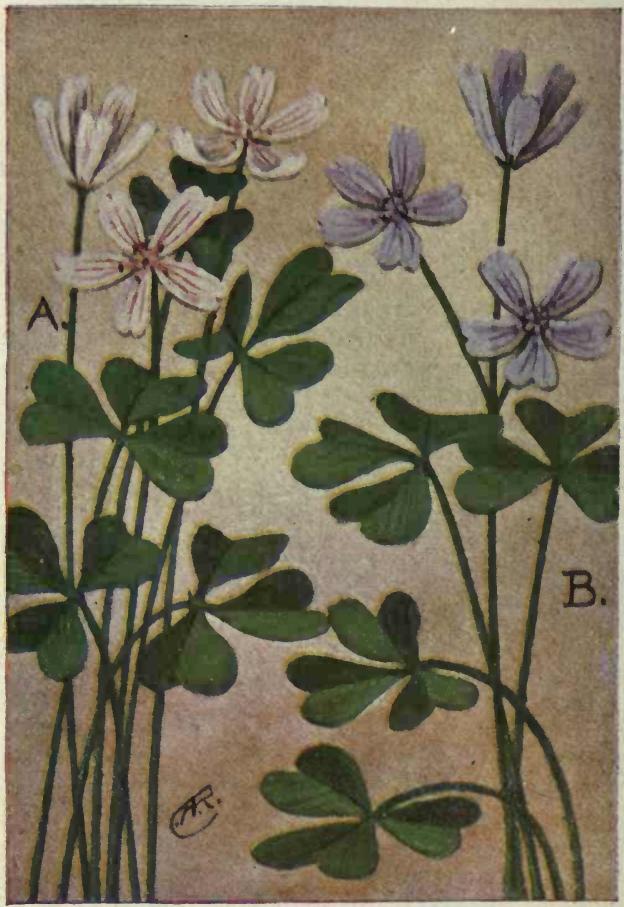

A. Wood Sorrel.

Oxalis acetosella.

B. Violet Wood Sorrel.

Oxalis violacea. 


\section{WOOD SORREL FAMILY (Oxalidaceae).}

A small family of low, recumbent herbs with trifoliate leaves and perfect, regular flowers.

WHITE WOOD SORREL (Oxalis Acetosella) is one of the most delicate and dainty of our woodland flowers. It is commonly found in cool, damp situations and is very partial to mountainous regions. The flowers are very frail looking, about an inch broad, borne on long slender peduncles from the root; the five, spreading petals are white, veined with crimson, giving the flower a delicate pinkish blush. The leaves are also on long, slender petioles from the root; they are trifoliate or clover-like, each of the three leaflets being inversely heart-shaped,- that is, with the end notched and with two rounded lobes. White Wood Sorrel is found from N. S. to Saskatchewan and south to N. E., N. Y. and in mountains to N. C.

VIOLET WOOD SORREL (Oxalis violacea) is a very dainty species, perhaps more beautiful than the preceding. The long slender flower stalks bear at their summits three or more pale magenta flowers, while those of the last species have but one. The flowers are very similar except in color, but are a trifle smaller than those of the white species.

The leaves of both these sorrels are very sensitive and fold up, if handled; they also close at dusk and only open when the suns rays beam on them the following morning. The juices of these plants are very acid; the well known Oxalic acid is obtained from the leaves of both these kinds of sorrel.

These Sorrels bear cleistogamous flowers at their bases, - that is, flowers that fertilize themselves in the bud and never open. The roots are perennial, creeping and scaly-toothed. 


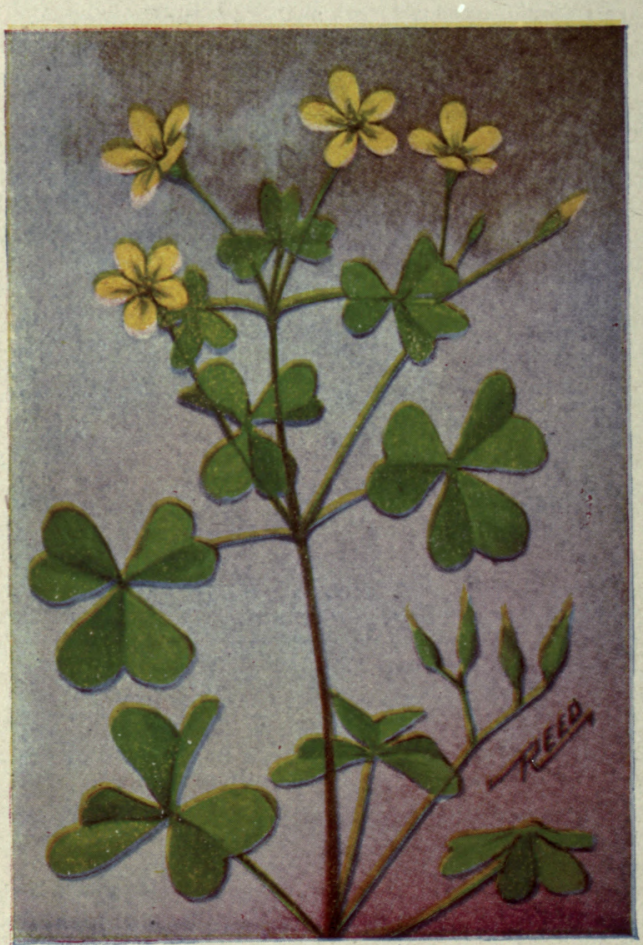

\section{Yellow Wood Sorrel. \\ Oxalis stricta.}


YELLOW WOOD SORREL; LADY'S SORREL (OXalis corniculata) is not a woodland plant but is very common along roadsides, in gardens, dooryards and fields. The pale green, slender stem is quite erect, branches but little, if at all, and grows from three to twelve inches tall. The leaves are longstemmed and trifoliate, the three leaflets being broadly heart-shaped. They are very sensitive and close if roughly handled. They also close at night, or "go to sleep," as children call it.

The leaves have very acid and sour juices, similar in taste to those of the common Red Sorrel that, by the way, belongs to an entirely different family (Buck-wheat). Country school children often chew the leaves of both of these, as the sour taste has an agreeable twang.

The bright golden-yellow flowers are quite fragrant; they open only in the sunshine and close tightly at night. They grow in few-flowered umbels at the end of the stem on slender peduncles from the axils of some of the leaves; the petals are thin, notched at the ends and set in a five-parted calyx. After their flowering season, tittle erect, pointed pods take the place of the flowers. This species is a very common herb or weed throughout our range.

\section{LOW YELLOW WOOD SORREL (Oxalis repens)} has several prostrate and creeping stems and numerous erect, leafy branches; it is very low, seldom attaining a height of more than three inches, although the prostrate stem may measure a foot in length. The little yellow flowers are set on short deflexed pedicels; this peculiar arrangement is more prominent after the seed pods have developed as the stems are even more deflexed at that period; it looks just as though some one had bent each of the flower pedicels sharply back at their junction with the stem or peduncle. This species is less common than the preceding. 


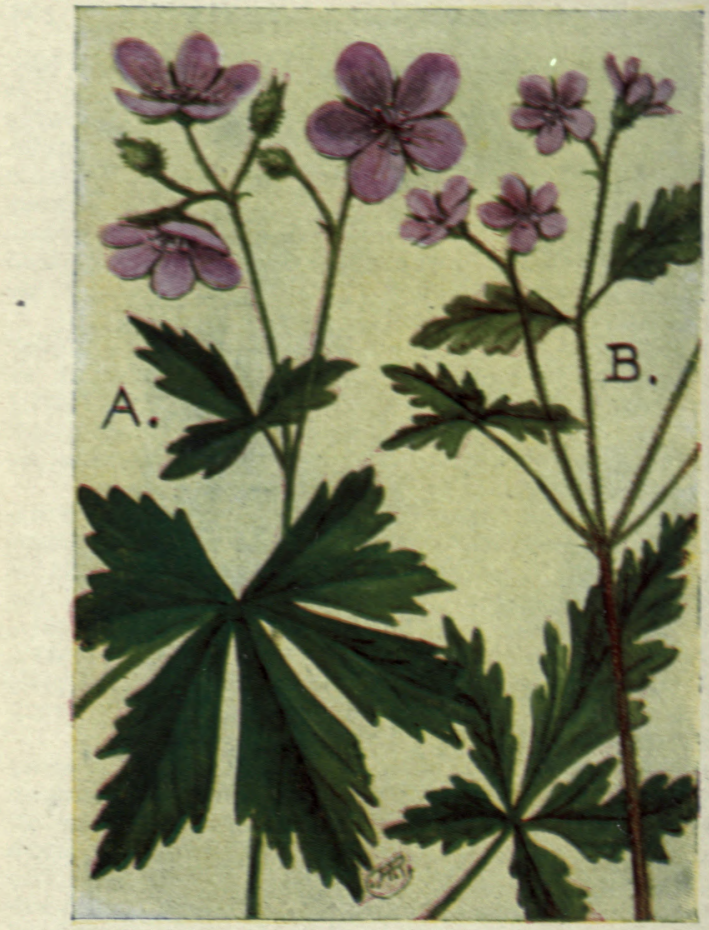

A. Wild Geranium; Cranesbill.

Geranium maculatum.

B. Herb Robert.

Geranium Robertianum. 
WILD GERANIUM; CRANESBILL (Ge ra $n$ i u m maculatum) is one of our most common woodland plants, flowering from May to July. The stem, the leaves and the flower calyx are rough-hairy, the former being quite stout and branching and attaining heights of one to two feet. The large, magenta or pale purple flowers are in loose, few-flowered clusters at the ends of the branches; the petals are large and rounded and slightly over-lap; they are delicate in texture and show several rather transparent lines radiating from their whitish, bearded bases; the ten stamens are all tipped with large, golden-brown anthers and surround a slender, green pistil. This pistil grows to be very long by the time the plant is in fruit, and it is this long beak that gives the species the name of Cranesbill; when the fruit is fully matured, it suddenly splits upwards from the base and scatters the seeds contained therein, for a distance of several feet.

The leaves of the Geranium are very beautiful; some of them are on long petioles from the base and others on shorter stems from the main plant stalk. Their texture is very coarse and fuzzy, and the surface often spotted with white or brown; they are palmately divided into five lobes, each of which is sharply toothed and pointed. It is very common from Me. to Manitoba and southwards.

HERB ROBERT (Geranium Robertianum) is a smaller edition of the last. Its flowers are similar, but smaller and coarser in texture. Its leaves are smaller and usually more deeply cleft. The stem is usually stained with red; both this and the leaves emit a strong odor when bruised.

The blossoms of this, and the last species, are frequented by various kinds of bees that are necessary to insure its pollenization, since the anthers have fallen away before the stigma ripens. Herb Robert is common from Me. to Minn. and southwards. 


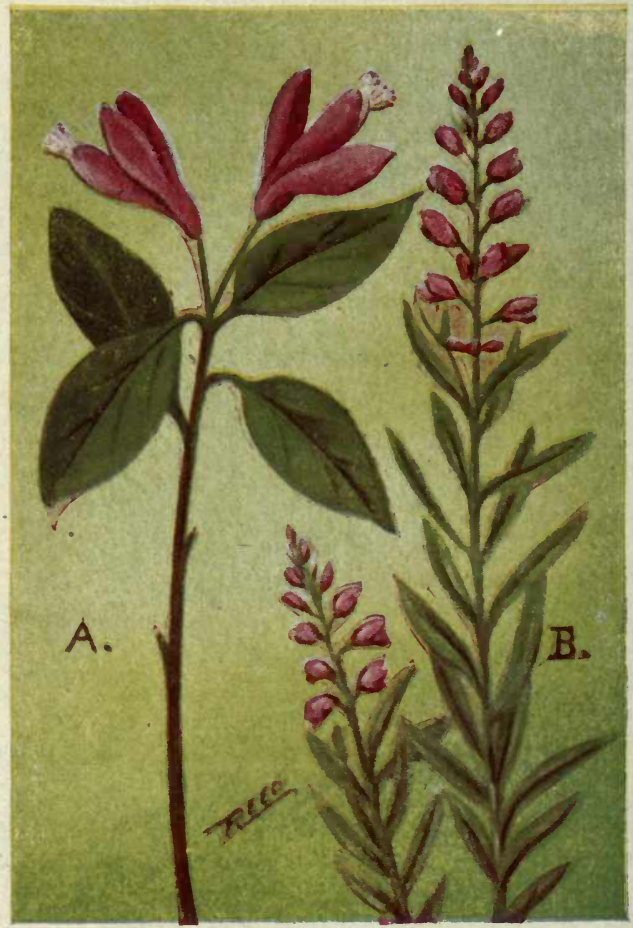

A. Fringed Polygala.

Polygala paucifolia.

B. Milkwort.

Polygala polygama. 


\section{MILKWORT FAMILY (Polygalaceae).}

This is a small family of herbs with opposite leaves and perfect but irregular flowers.

FRINGED POLYGALA (Polygala paucifolia) is a dainty and low perennial, usually rising but four or five inches from the ground; the stem bends sharply as it enters the soil and continues into a long, slender rootstalk often a foot in length. A few broad, ovate, pointed, shining, bright green leaves are crowded along the stem near its top and one or two tiny ones, resembling scales, clasp the stem lower down. Either one or two flowers are at the summit of the stem; they are quite large, being nearly an inch in length; the two lateral sepals are large and wingshaped (one of the common local names for this species is "Bird-on-the-Wing" because of the fancied resemblance to a bird in flight); the three petals are joined together to form a tube, through which the yellow stamens and pistil protrude; the two spreading sepals are crimson pink and the petals are lighter or white, the lower one being fringed or bearded. This Polygala is common in damp, rich woods from N. S. to Manitoba and southwards to the Gulf, flowering during May and June. It is largely dependent upon the honeybee for fertilization.

MILKWORT (Polygata polygama) is a slender-stemmed species from five to fifteen inches high; the stem is closely crowded, alternately, with narrow, oval, pointed, stemless leaves. The dull crimson flowers are borne in long, slender racemes at the top of the stem. Many, usually simple, stems grow from the biennial root; sometimes they have a single branch near the top. It also bears cleistogamous flowers on subterranean shoots; it is from these that it gets its specific name of polygama. It is quite common everywhere in dry sandy soil. 


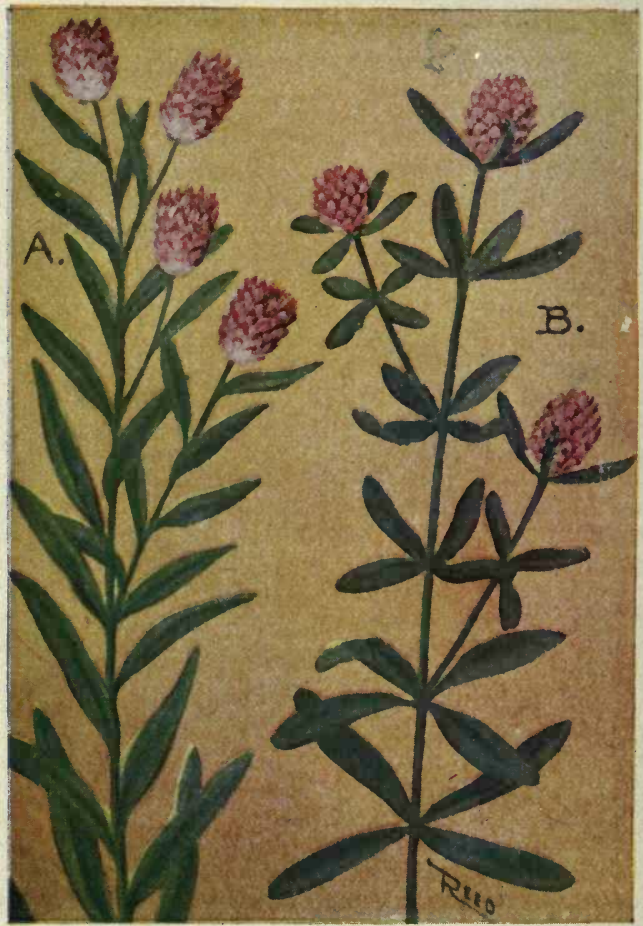

A. Milkwort.

Polygala sanguinea.

B. Cross-leaved Milkwort.

Polygala cruciata. 
FIELD or PURPLE MILKWORT (Polygala sanguinea) is a sturdy little pink-headed plant that grows in fields or meadows or along roadsides, often in company with Hop Clover; it is a strange fact that the flower heads of these very different species should be shaped so nearly alike. The slender, erect, wiry stems are very leafy and slightly branched at the top. A single round or cylindrical flowerhead terminates each branch, and others may be on slender peduncles from the angles of the upper leaves.

The flowers, proper, are concealed beneath the large, broad, scale-like, crimson-pink sepals that tightly overlap each other and form the head; these scalelike sepals correspond to the wings on the Fringed Polygala, the true petals and minutely crested keel being shorter and not visible from the outside. The small, stiff, acutely-pointed leaves are densely alternated on the stem up to the flower head. The plant grows from 6 to 12 inches high, and abounds throughout the U. S.

CROSS-LEAVED MILKWORT (Polygala cruciata) has spatulate-shaped leaves arranged in fours around the stem,-cross-like. The stem is quite branchy, and grows from 4 to 14 inches high. At the end of each branch, seated within the four terminating leaves, is a dainty little, globular, pink flower-head. Its construction is more open than that of the preceding species; the pink, sharply-pointed sepals do not hug closely together, but are slightly spread so that the tiny petals and stamens may be seen. The little heads bear considerable resemblance to tiny Red Clover blossoms.

We find this species around the edges of swamps or in rather moist fields, from Me. to Minn. and southwards to the Gulf of Mexico. Both this species and the last have a long period of bloom; we may find their flowers from June until September. 


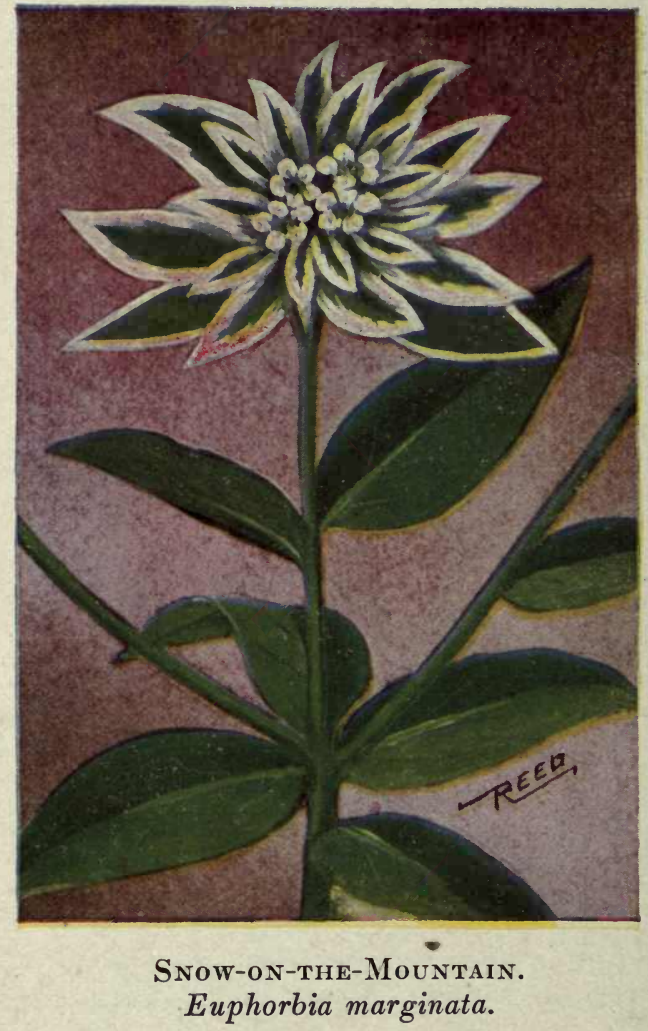




\section{Wild Flowers East of the Rockies}

SPURGE FAMILY (Euphorbiaceae).

This family contains a dozen different genera, all agreeing in that they have acrid, milky juices.

SNOW-ON-THE-MOUNTAIN; W H I T E-E D GED SPURGE (Euphorbia marginata) is a large bushy herb often cultivated because of its beautiful, whitemargined foliage. The stem is very stout and branchy, and grows from 2 to 3 feet high. The leaves are dark green, large, ovate-pointed and seated on the stem; the lower ones are quite similar in shape to those of the common milkweed and are alternated on the stem; those near the end of the branches are crowded, opposite or whorled about the stem; the terminal ones have the edges of the leaves more or less widely margined with clear white.

The flowers are rather small, grouped in clusters in the center of the terminal cluster of margined leaves. The staminate and pistillate flowers are on different plants. The involucre is five parted and has five white petals.

When broken, both the leaves and stems exude quantities of a milky juice. This species of Spurge grows in dry soil from Minn. and Ohio west to Colorado, and is sometimes found in parts of the East where it has escaped from gardens.

PAINTED LEAF (Euphorbia heterophylla) is a peculiar species found on rocky, woody slopes from Minn. southwards to Texas and in Fla. The stour, erect, branching, smooth stem grows from one to three feet high. The alternating leaves vary from ovate, sinuous-toothed, to lanceolate and smooth edged. The ones crowded at the ends of the branches usually have red bases. The involucres in the terminal cluster are five-parted.

CYPRESS SPURGE (Euphorbia Cyparissias) is an escape from gardens. It has very numerous, linear leaves, and a large terminal cluster of greenish-white flowers stained with russet-red. 


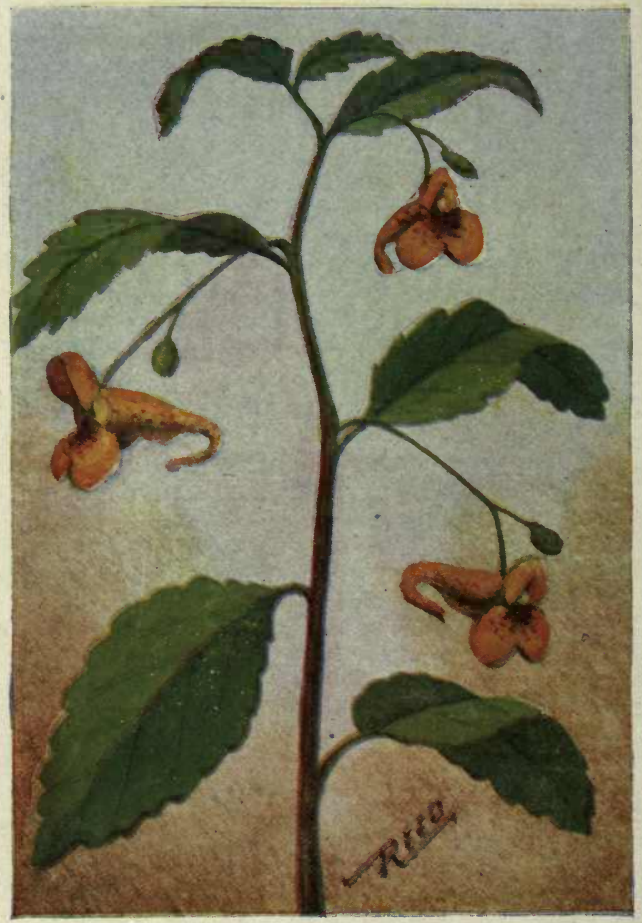

JeWELWEED; TOUCH-ME-NOT.

Impatiens biflora. 


\section{Wild Flowers East of the Rockies}

JEWEL-WEED FAMILY (Balsaminaceae). JEWEL-WEED; SPOTTED TOUCH-ME-NOT (.Impatiens biflora) is a common rank-growing herb with a stout, but fragile, branching stem. It has many peculiarities and a great many local names, all of which pertain to some of these peculiarities. Its most common name of Jewel-weed is very appropriate, as the flowers certainly do resemble jeweled pendants hanging from the slender branches. The large, inflated sac, which is really one of the three sepals, is orangeyellow, spotted with brown; it is longer than it is broad and has a sharply incurved spur about half the length of the sac. Two of these singular flowers droop from the ends of each thread-like peduncle, but only one flowers at a time.

The slim seed-pod is the cause of two very commonly applied names,-Touch-me-not and Snapweed. When nearly ripe, these pods can scarcely be touched but they will suddenly, almost explosively, burst and scatter their seeds in all directions. One not acquainted with their ways, is always startled when he accidentally brushes against the mature Touch-me-not.

The leaves are very delicate in appearance, and their light, slender stems are almost translucent; they are ovate, round-toothed, dull green above and whitish-green below; owing to the coloring of the leaves, Jewel-weed is often locally called "Silver-leaf." The stem is hollow and juicy, and stained with reddish.

PALE TOUCH-ME-NOT (Impatiens pallida) is very similar. The flower pouch, however, is paler and with few or no brown spots, the sac is as wide as it is long, and the curved spur is less than one-third the length of the sac. The stem is light green. Both species are common in moist, shady places throughout the United States. 


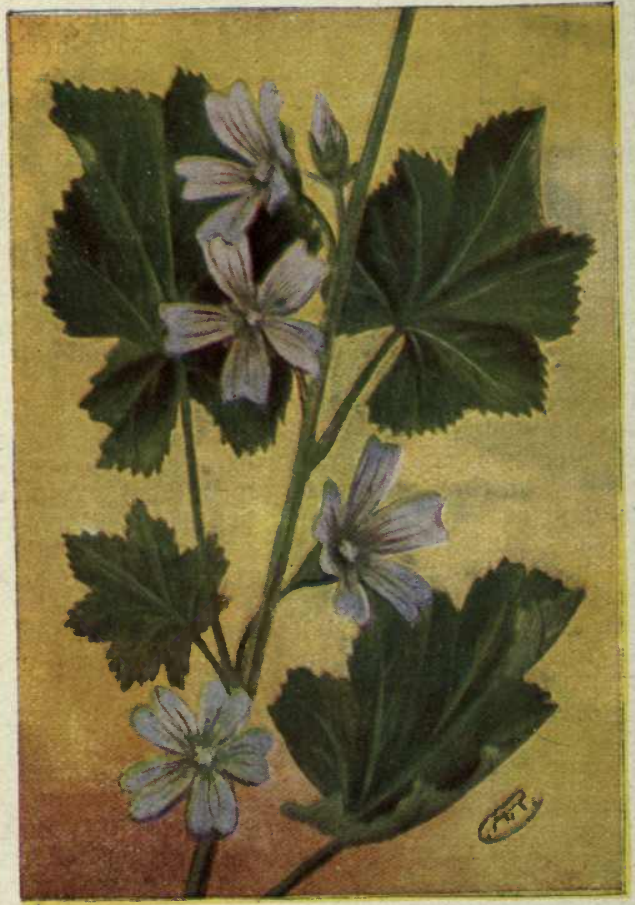

Common Mallow.

Malva rotundifolia. 


\section{MALLOW FAMILY (Malvaceae.)}

Composed of herbs or shrubs with alternate, stipulate, irregular leaves, perfect, regular flowers and having mucilaginous juices.

\section{COMMON MALLOW; CHEESES (Malva rotundi-} folia) (EUROPEAN) is a very common weed about dooryards, especially in the country, and along the edges of cultivated fields. The long stalks spring from biennial roots and creep over the ground, the branches being 6 to 24 inches in length. The dark green, round leaves are very handsome; they have a shallow-lobed and very finely toothed edge and are deeply, palmately-ribbed. The leaves, their stems and the plant stems are rathe rough.

The small, wide-spread, bell-shaped flowers are clustered close to the stalk on short stems from the axils of the leaves. The five petals have notched tips, are white, delicately tinted with pink or pale magen$\mathrm{ta}$, and have veinings of a deeper shade. The flowers are attractive and, were they not so abundant about our very doors, would more often be appreciated. The seed is hard, flat and rounded, composed of a dozen or more carpels; it is eaten by children with great relish, these being the "cheeses" that give the species one of its common names.

Like so many others of our flowers, this species came to our shores from across the Atlantic. As usual with foreign plants introduced into this country, it thrives here better, and multiplies even faster, than in its native home. It is the same with all classes of life. The English Sparrow, to our sorrow, is so strongly entrenched here that it can never be driven out. The Ring-necked Pheasant, introduced from China, is very abundant in the Northwest and, even in the East, thrives better than the native Grouse. 


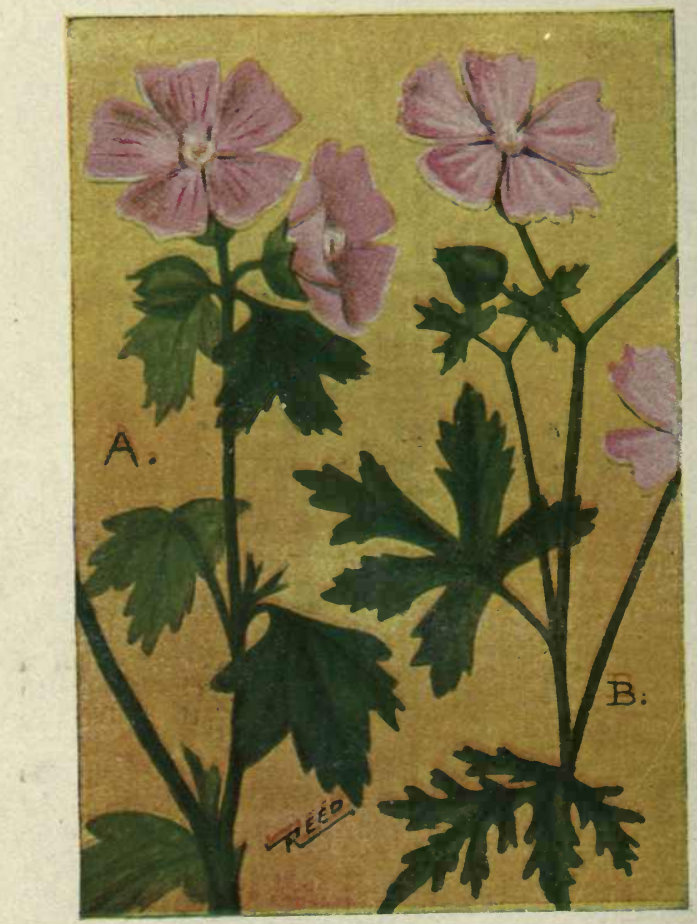

A. High Mallow.

Malva sylvestris.

B. Musk Mallow.

Malva moschata. 


\section{HIGH MALLOW (Malva sylvestris) (EUROPEAN)}

is a tall biennial with a coarse branching stem, often attaining a height of three feet, or even more on waste land; usually, as we see it along roadsides, it is only from one to two feet in height. Both the stems and the leaves have a thick covering of hair; the latter are all borne on long stems, alternating along the plant stalk, and are divided into five or seven lobes with a serrate outline. The flowers grow in clusters of perhaps a half dozen from the axils of the leaves; they have five, heart-shaped petals of a purplish color, with two or three conspicuous veins of a darker shade of the same color. This species is often erroneously called Marsh Mallow, because of the similarity of the names. The latter plant, though, is quite different from the present species.

The Mallows get their generic name of Malva, in allusion to the soothing effect of the mucilaginous juices of the root and stem. This is used for the making of a number of soothing compounds.

MUSK MALLOW (Malva moschata) (EUROPEAN) is a similar species with the leaves deeply and palmately slashed and toothed. Several hairy, branching stems proceed from the perennial root, to heights of one or two feet. The flowers are peculiar in that the ends of each of the five rose-colored petals are roughly notched, looking as though they had been bitten off.

This species received its name from the fact that when the leaves are crushed, they give forth a slight odor of musk. The blossoms oceur, singly or in pairs, from the axils of the leaves, near the ends of the branches. It blooms in July and August in waste places, often along roadsides, where it has made its escape from gardens. It is now quite abundant in northern New England and southern Canada. 


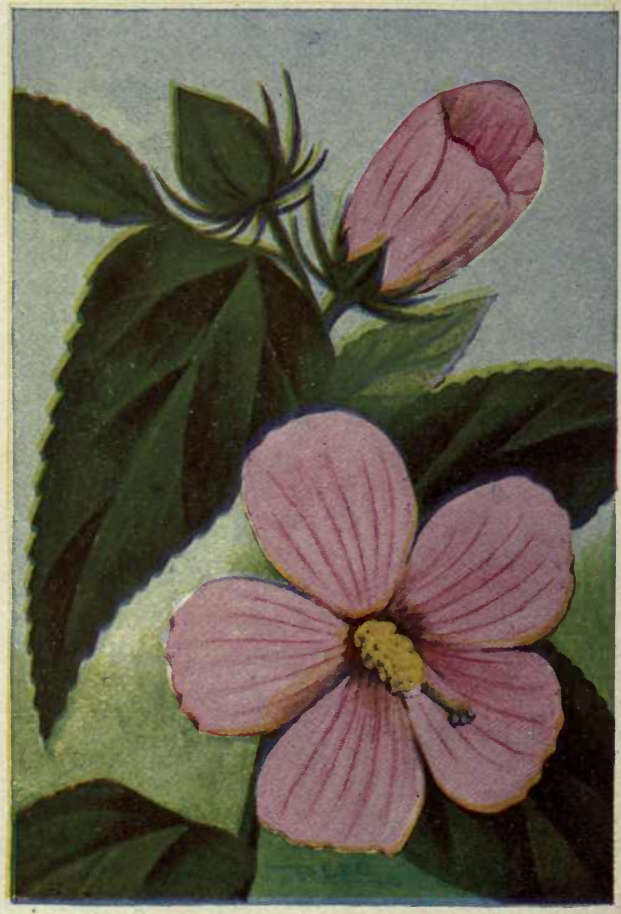

Rose Mallow.

Hibiscus moscheutos. 
ROSE MALLOW (Hibiscus Moscheutos) is a tall, leafy perennial, bearing flowers that easily rank as being among the largest and most beautiful of any of our wild flowers. The stem is quite stout and inclined to be hairy. The large leaves are ovate-pointed and toothed; they are stemmed, and alternate along the main plant stalk. The lower ones are often threelobed.

The flowers grow on short stems at the end of the upright stalk. But one usually blooms at a time and there are not a great many buds; what they lack in profusion of bloom, this species fully makes up in size, for its blossoms measure four to six inches across. The five, large petals, are a delicate rose color, conspicuously veined, and often with crimson bases. The long, slender pistil divides at the tip, into five flat-headed stigmas; for more than half its length, it is encased in the long stamen column, the sides of which are covered with yellow anthers.

The Rose Mallow grows in swamps and marshes near the coast, from Mass., southwards, and along the shores of the Great Lakes to Mich. It blooms from July to September.

For twenty years a small colony of perhaps half a dozen of the beautiful plants grew in a certain swamp near Narragansett Bay in R. I. They were so surrounded by bogs that it was very difficult to reach them, but finally they were found by summer visitors and the plants, root and all, removed bodily. Such is the fate of our beautiful flowers.

MARSH MALLOW (Althea officialis) is a species that has been introduced from Europe and is found in some of the salt marshes near the coast. The leaves are downy, three-lobed, toothed and stout-stemmed. The hollyhock-like flowers are in small clusters from the angles of the leaves. The thick root furnishes material for confectionery. 


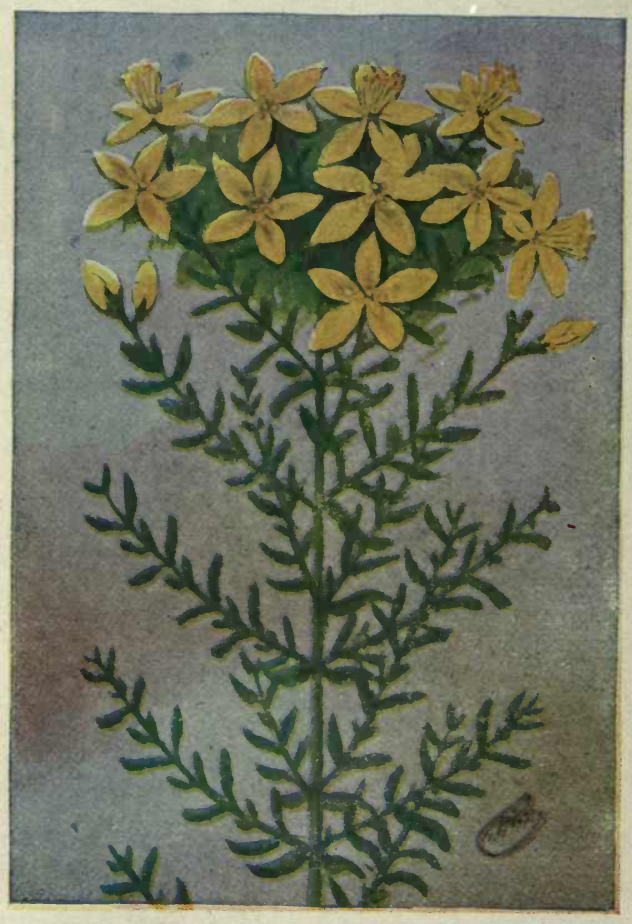

Common St. Johnswort.

Hypericum perforatum. 
ST. JOHNSWORT FAMILY. (Hypericaceae).

A small family of shrubs and herbs, having opposite, toothless, and generally stemless leaves, and regular, four or five-petalled flowers.

COMMON ST. JOHNSWORT (Hypericum perforatum) (EUROPEAN) is a wanderer from the old world that, having reached our hospitable shores, proceeded to multiply and over-run the native plants so that it is now regarded by farmers as a pest along with the Wild Carrot and Mustard. If it is true that in the struggle for existence, the fittest survive, then surely this species must be one of the fittest; we often see it growing lustily in circumstances under which few plants could exist. It grows promiscuously in fields or along roadsides. Even a generous sprinkling of tarvia, received when the roads were sprinkled, failed to kill this plant, although many other species died from the effects.

It has a slender but tough stem from one to two feet high; it has numerous short branches, each crowded with tiny, stiff, oval leaves. The upper branches terminate in clusters of 5-parted, goldenyellow flowers with numerous, long, yellow stamens. This species blooms from July until September.

SPOTTED ST. JOHNSWORT (Hypericum punctatum) is a similar species, with paler flowers having fine black streaks on the petals, especially on the under sides; the leaves are thickly dotted with black and brown. It is found in moist places or thickets from N. S. to Minn. and southwards.

SHRUBBY ST. JOHNSWORT (Hypericum prolificum) is a very shrubby species, with stout branching stems. The deep green, linear-oblong leaves are closely seated on the stem and at their bases are other tiny leaves or leaflets. The flower clusters are thick, flat and bright golden-yellow; the numerous stamens are orange-yellow. Common from N. Y. to Minn. and southwards. 


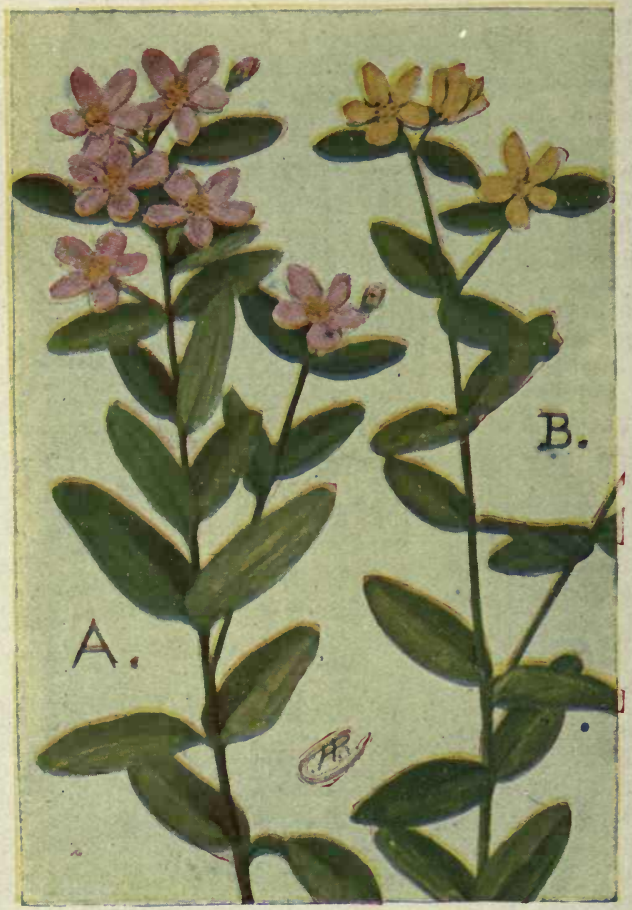

A. Marsh St. Johnswort.

Hypericum virginicum.

B. ST. JoHNswort.

Hypericum ellipticum. 
MARSH ST. JOHNSWORT (Hypericum virginicum) is an entirely different species in every respect. The stem is slender, erect and from one to two feet in height, growing from perennial running rootstalks. The comparatively large leaves are light green, with brownish spots and a white bloom on the under side; they are closely set, oppositely on the stem.

The flowers are in small clusters terminating the branches; the five petals are of a pinkish, flesh-color and surround three groups of golden-yellow stamens.

This species is probably chiefly self-pollenized; the three bundles of stamens are close to the stigmas, and just on a level with them, so that a visiting insect could scarcely help depositing pollen on the stigma of its own flower. True, some of it may be left on his body to carry to another blossom, so that occasionally cross-fertilization may occur. After the flowering season, the flower contracts so that the anthers and stigmas are in contact with each other. Later in the summer, after the flowers have entirely withered away, the stem and the leaves take on a rosy tinge that attracts the attention of the observer, even though he be not interested in flowers.

ST. JOHNSWORT (Hypericum ellipticum) has a simple usually 4-angled stem, sometimes with a single branch near the top. It grows from 8 to 20 inches high and is quite leafy. The leaves are comparatively large, about the same shape as those of Marsh St. Johnswort. At the top are a few five-petalled flowers with bright golden-yellow stamens. The ovoid pods succeeding the flowers are brownish. This species is found in damp places or along streams from Me. to Minn. and south to $\mathrm{Pa}$. 


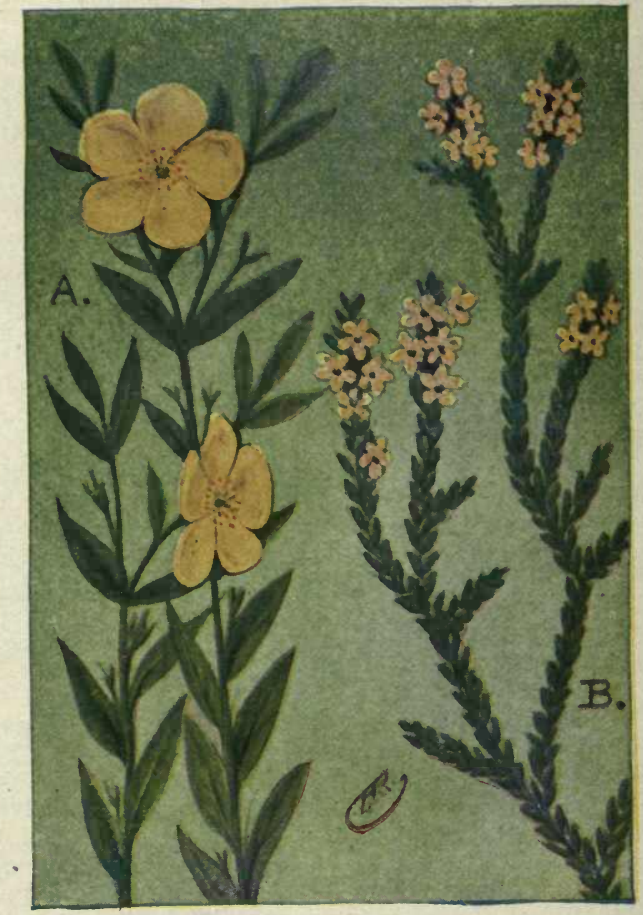

A. Rock Rose; Frost-weed.

Helianthemum canadense.

B. Hudsonia.

Hudsonia tomentosa. 


\section{Wild Flowers East of the Rockies}

ROCKROSE FAMILY (Cistaceae).

A small family of small shrubs or herbs, having regular flowers with three or five petals and five sepals, the two external ones being small and bractlike.

FROSTWEED; ROCKROSE (Helianthemum canadense). This little perennial is very remarkable and unique, because late in autumn, crystals of ice form about the cracked bark of the root. It is also remarkable for the fact that it has two sets of flowers, the first ones in June and later ones in July or August. The first flowers are large and solitary, about one inch across, with five showy yellow petals; these are very delicate and the petals soon fall.

Continuing its growth the plant developes several short branches near the top, on each of which will appear from one to four smaller flowers, some with yellow petals and some without any.

The leaves are small, oblong-lanceolate, hoary with white hairs on the under side, alternating along the stem that rises from 10 to 18 inches high. Both the early and late flowers are fertile, the seed pods of the former are about a quarter inch long, those of the latter, less than half as long. Frostweed grows in sandy, dry soil from Me. to Minn. and southwards.

HUDSONIA (Hudsonia tomentosa) is a low branching, little shrub rising only 5 or 10 inches above ground. Its branching stems are closely crowded with tiny, scale-like, oval leaves about one-half inch long. These are set as closely about the stem as possible and hug closely to it, instead of spreading.

The small, yellow flowers that are crowded along the ends of the branches, open only in sunshine; the five tiny yellow petals surround numerous stamens and a long, slender style. Hudsonia is found on sandy shores from N. B. to Va. and along the Great Lakes. 


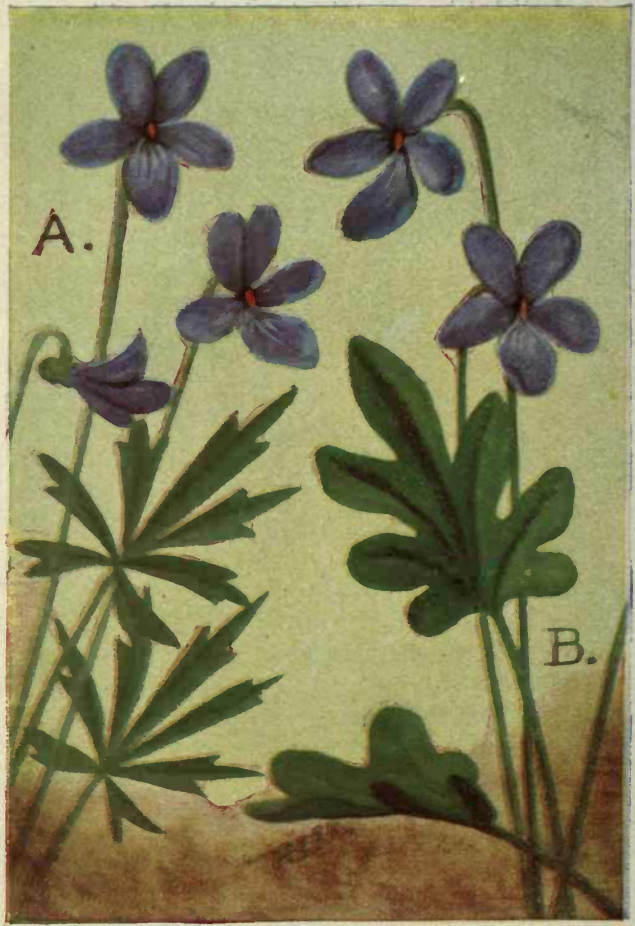

A. Bird's-Foot Violet.

Viola pedata.

B. Palmated Violet.

Viola palmata. 


\section{VIOLET FAMILY (Violaceae).}

A small family of herbs with perfect but irregular flowers having five petals, the lower one of which is spurred; flowers nodding.

BIRD-FOOT VIOLET (Viola pedata) is a well known and very characteristic violet, one not apt to be confused with the other species of blue violets. The flowers of this species are the largest of the blue violets; they are blue-violet or purple-violet and have a bright orange center, formed by the large anthers that block the throat of the blossom. The lower, large petal is slightly grooved, veined with white at its base and has a short spur to hold nectar for its valued insect visitors, these being bumblebees and small butterflies.

The leaves grow on long petioles, in dense tufts, from the root; each leaf is cut into five to eleven parts, all sharply pointed, and the middle and lateral ones with their ends notched or cleft.

EARLY BLUE VIOLET; PALMATED VIOLET. (Viola palmata) has slightly smaller blue flowers with bearded side petals; occasionally the flowers may be nearly white. Its petals are narrower than those of the last species and the anthers are smaller and less conspicuous.

The basal leaves are very variable in shape, ranging from heart-shaped with rounded teeth and an unbroken edge to palmately cleft ones with five or seven rounded lobes; they are never cleft entirely to the stem as are those of Bird-foot Violet, but only about half way, and all divisions are rounded with no sharp angles. Both of these violets are common in dry ground, the former in fields or the borders of swamps, and the latter usually in thin woodland, from Me. to Minn. and southwards. 


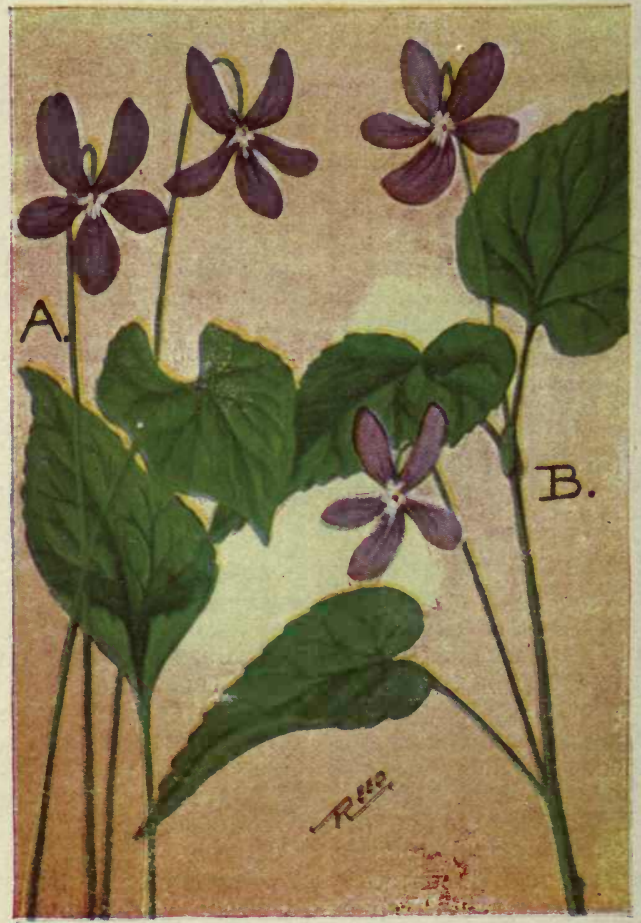

A. Common Violet.

Viola cucullata.

B. Canada Violet.

Viola canadensis. 
COMMON VIOLET (Viola cucullata) is the commonest and best known of all the violets. It grows in low land everywhere,-in woods, meadows, marshes or along roadsides. It is a very beautiful and variable species both as to size and color of blossoms and to shape of the leaves. If the ground is dry, the plants will be small, and the flowers nodding from scapes perhaps 3 inches high. In rich swampy ground we find it at its best, the handsome flowers sometimes proudly waving their heads on slender stems a foot long.

The flowers are sometimes a deep purple and again may be a light blue, or even nearly white. The two upper petals are usually darker near the throat; the three lower ones shade to white at the throat, the side ones being beautifully fringed or bearded. The leaves are usually heart-shaped, round-toothed and concave or furled; they are on long stems from the base.

CANADA VIOLET (Viola canadensis) is the most common of the leafy stemmed blue violets. You will notice that the preceding species all had their leaves from the base, and the flowers nodding on slender scapes, while this one has leaves growing on the slender stem and flowers above them on peduncles, springing from the angles of the leaves. The leaves are heart-shaped, pointed and serrate. The flowers are pale violet or even white, the lower, spurred petals having yellowish bases, streaked with purple veins; the side petals streaked with purple and bearded. This species is quite common in woods throughout the United States.

Violets are among our most popular flowers. Varieties obtained from our wild ones are cultivated in enormous quantities for adornment and for perfume. The violet is the state flower of Rhode Island, and has been adopted as their representative flower by several colleges. 


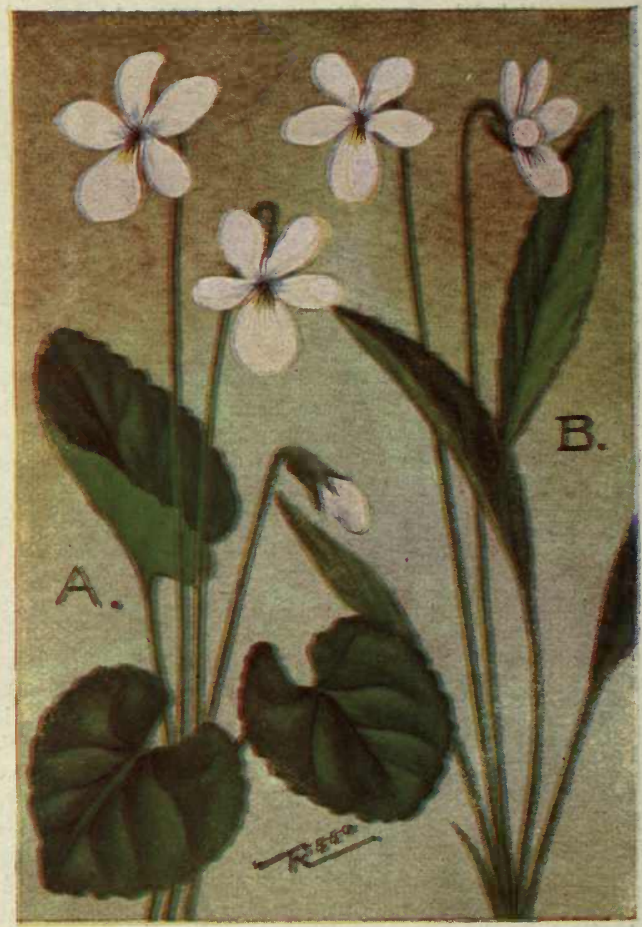

A. White Violet; Sweet Violet. Viola blanda.

B. Lance-leaved Violet.

Viola lanceolata. 


\section{SWEET WHITE VIOLET (Viola blanda) is the}

most fragrant of our wild violets, regardless of color. It is a most charming plant, but very diminutive, in fact it is probably the smallest of the entire family. Occasionally we may find them in some exceptionally favorable locality growing to a height of perhaps six inches, but the usual height will barely exceed two inches. The plant is stemless, that is the leaf stems and flower stalks all spring directly from the root.

The delicate, white flowers are small,-barely a half inch across and many of them not more than a quarter of an inch. The petals are not widely expanded, and the top two are usually more or less curved backwards; the three lower petals are very delicately veined near the throat with purple, and the lateral ones are sometimes fringed of bearded. By the way, this beard that is found on most of the violets is there for a purpose,-to prevent crawling insects, such as small ants, from gaining admittance to the store of nectar in the spur back of the throat. Useful bees or butterflies can reach through with their tongues, but it is almost impossible for other pilferers to force their way through bodily.

The leaves of the common white violet are rounded heart-shaped with slightly scalloped or round-toothed edges. It is very common in swamps and moist woods throughout the United States and southern Canada.

LANCE-LEAVED VIOLET (Viola lanceolata) is a taller, more slender species growing from 3 to 8 inches high. Its leaves are lance-shaped, scallop-edg. ed and on long stems from the root. The white flowers are only slightly fragrant; the three lower petals are strongly veined with purple and the two side ones are rarely bearded. It is commonly found in swamps and moist ground from N. S. to Minn. and southwards, flowering from April to June. 


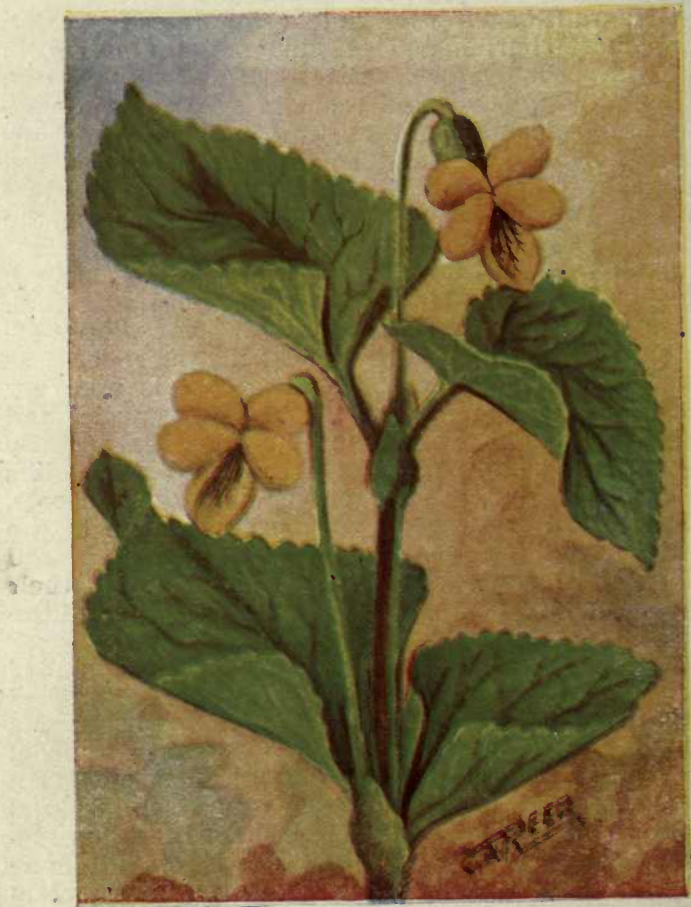

Downy Yellow Violet.

Viola pubescens. 
DOWNY YELLOW VIOLET (Viola pubescens) is a large very handsome violet that prefers, for its habitat, dry hilly woods, often by the side of rushing brooks, but not usually where the soll is moist.

In a certain piece of woodland, a small brook tum. bles its way noisily along its rocky bed. Alders sparingly line both banks of the brook, banks that slope steeply upward on either side. In one place along it, in a place the size of an ordinary room, is a colony of Yellow Violets, growing so closely together that one can barely see the ground between the leaves. Directly over this wild flower bed, a pair of Wood Thrushes make their home, year after year. Ordinarily Yellow Violets bloom in April and May, but in this particular case their bloom is delayed until the latter part of May, the time when their feathered neighbors have their home also completed.

The Yellow Violet is one of the tallest members of the family, its stem ranging from 6 to 18 inches in length. Both the stems and the leaves are wooly hairy. There are from two to four leaves growing from the stem near its summit; they are heart-shaped, pointed, and either toothed or scalloped. The flowers, rising on slender peduncles from the axils of the leaves, are rather large and bright yellow; the two lateral petals are heavily bearded and the lower one is handsomely veined with purple. These beards compel visiting insects to brush against the stigma and then against the anthers before reaching the nectar in the short spur.

Most of the violets, during the summer, have apetalous or cleistogamous flowers on short peduncles from the root; these never open, but are fertilized in the bud. Closely allied species when growing near each other, often form hybrids that are confusing except to the expert botanist.

SMOOTH YELLOW VIOLET (Viola scabriuscula) is similar to the former but, normally, is smooth or cnly very slightly hairy. Yellow Violets are found from N. S. to Manitoba and southwards to Md. and Kans. 


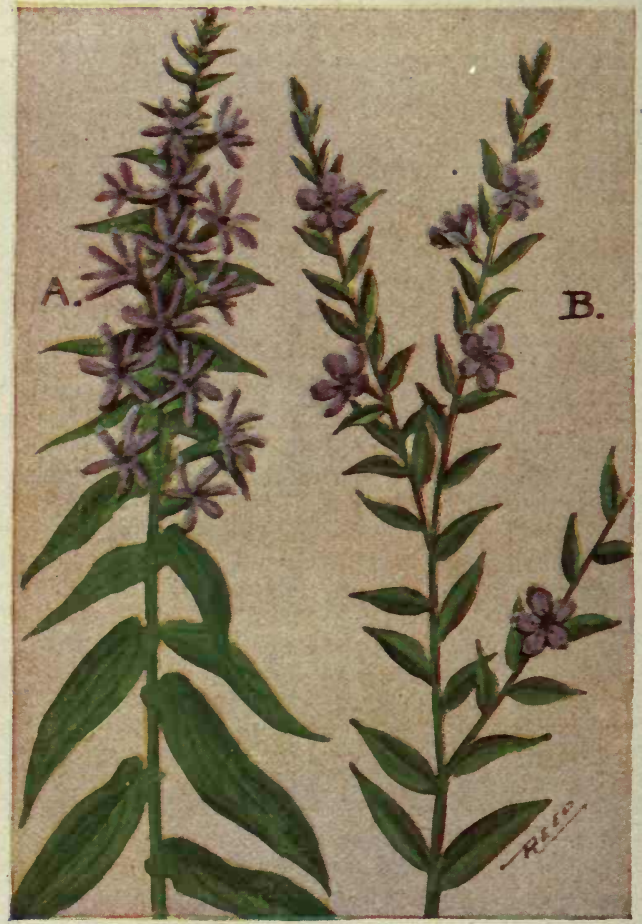

A. Purple Loosestrife.

Lythrum salicaria.

B. Loosestrife.

Lythrum alatum. 


\section{LOOSESTRIFE FAMILY (Lythraceae).}

A small family of herbs or shrubs, usually with opposite, entire-edged leaves and perfect flowers.

\section{PURPLE or SPIKED LOOSESTRIFE (Lythrum} Salicaria) (EUROPEAN). Undoubtedly this species, which came to us from Europe, is the most beautiful of the genus. It is quite commonly known by the names of "Long Purples" and "Spiked Willow-herb." It is a very ornamental plant and forms a very attractive contrast to the surrounding vegetation when seen growing in profusion, as it so often does, along the banks of rivers and ponds. The rootstalk is perennial so that, once established, this species will spring up year after year in the same place.

The plant grows from 2 to 4 feet high and branches towards the top; during the flowering season, from June to August, we may see from one to, often, as many as half a dozen of these beautiful, long spikes flowering simultaneously on the same plant. The green leaves are stemless, lance-shaped and grow oppositely, or in circles of three, on the slightly hairy stem. The many purple flowers, making up the spike, each have six long petals and are trimorphous, that is flowers on the same plant have, relatively, three different lengths of stamens and pistils. They are cross-fertilized by bees and various species of butterflies. Purple Loosestrife is found locally in swamps and on marshy borders of streams from Me. to Del. and westwards.

LOOSESTRIFE (Lythrum alatum) is a tall slender, native species growing 1 to 3 feet high, angular and branching. The deep green, lance-shaped leaves are set oppositely on the lower stem and alternately on the upper branches. The flowers appear sparingly from the axils of the leaves near the ends of the branches. This species grows in moist ground from N. S. to Minn. and southwards to the Gulf. 


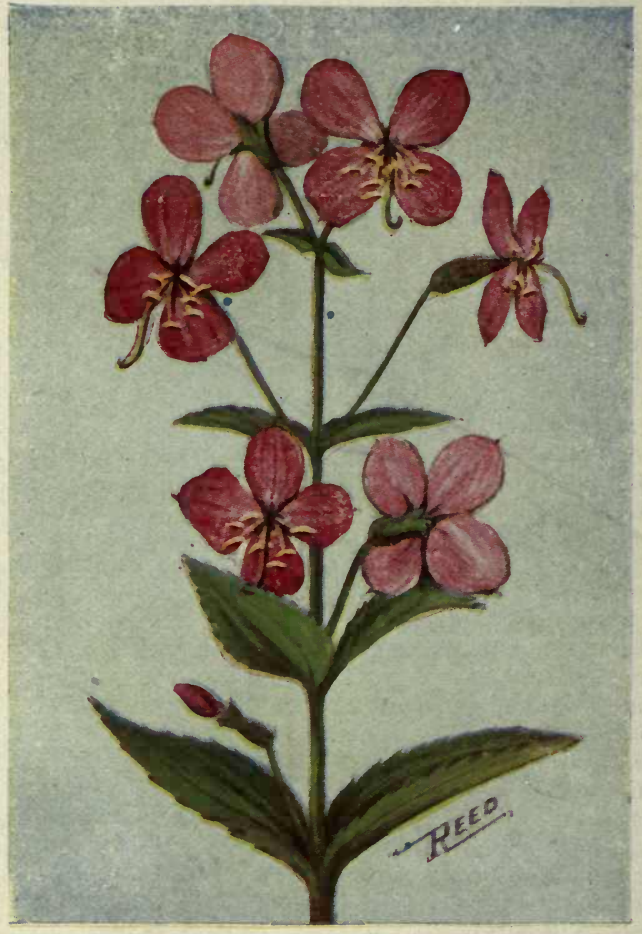

Meadow Beauty; Deergrass. Rhexia virginica. 


\section{MELASTOMA FAMILY (Melastomaceae).}

MEADOW BEAUTY (Rhexia virginica) is a pretty little plant that always causes a thrill of admiration to pass through us as we come across it in grassy marshes where other flowers are usually few and very far between.

The individual blossoms are very handsome, but the plant, as a whole, has rather a disheveled appearance; it has numerous buds, two or three of which, only, open at a time, lasting but for a short space, the petals then falling off and the calyx and long stamens becoming withered and brownish; these detract greatly from an otherwise very beautiful plant.

Meadow Beauty or "Deer-grass' is a perennial, has a stout stem, quite branching and sharp-pointed, ovate, toothed, three-ribbed leaves, seated oppositely on the stem. The flowers grow on slender peduncles from the angles of the upper leaves; they have four large, rounded, magenta petals, each with a short, sharp point at the tip. The eight stamens are long and slightly unequal, the anthers being exceptionally large and bright golden-yellow; the calyx is urnshaped, with four, short, sharp teeth. Meadow beauty is found blooming during July and August in sandy marshes and shores from Me. to Fla. and in the states bordering the Mississippi. Several other species are found, differing but slightly, as follows:

Rhexia aristosa has a square, or wing-angled stem, linear-oblong leaves and pink or purple petals. Found in pine barrens from N. J. to Ga.

R. mariana has a round stem and linear-oblong leaves with short stems. Found in sandy swamps from N. Y. to Fla. and west to Mo. and Tex.

R. ciliosa has a square stem, broad, ovate leaves few, stemless flowers with straight anthers. Found from Md. to Fla. and La. 


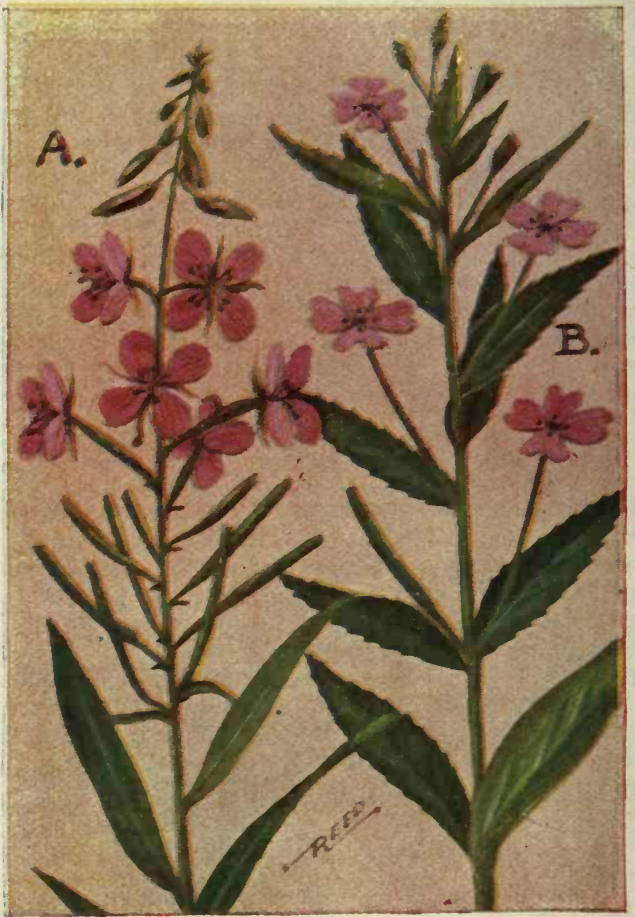

A. Willow Herb; Fireweed. Epilobium angustifolium. B. Hairy Willow Herb. Epilobium hirsutum. 


\section{EVENING PRIMROSE FAMILY (Onagraceae).}

A family of herbs or shrubs with perfect, usually four-parted flowers, four petals, four sepals, four or eight stamens and a two or four-parted stigma.

GREAT WILLOW-HERB; FIREWEED (Epilobium angustifolium) springs up in profusion and attains its greatest growth in clearings or recently burned land; hence the name of "Fireweed" by which it is most commonly known, a name which is also given to an entirely different plant (Erechtites hieracifolia), belonging to the great Composite Family.

The tall, upright stem is usually simple, but occasionally slightly branched at the top. It attains heights of from two to eight feet. The closely alternating leaves are long, lance-shaped, greatly resembling those of the Willow, from which fact it received its other common name, a name, by the way, that it is advisable to apply to this species as it will avoid confusion of conflicting names.

The flower spike is long; the flowers, blooming from the bottom, upwards, leave in their wake, numerous upright, long, slender pods. The four pink petals of each flower are very broad and rounded at the outer end, alternated with narrow brownish sepals; it has eight stamens and a prominent 4-parted pistil. They are apparently seated on the ends of the slender undeveloped pods.

The Great Willow Herb is abundant throughout our range in low ground, blooming during July and August.

HAIRY WILLOW HERB (Epilobium hirsutum) (EUROPEAN) has become naturalized and is fairly common in waste places and about old dwellings. It is branchy, hairy, has finely toothed, stemless leaves, and four-parted, magenta flowers growing from the angles of the upper leaves. 


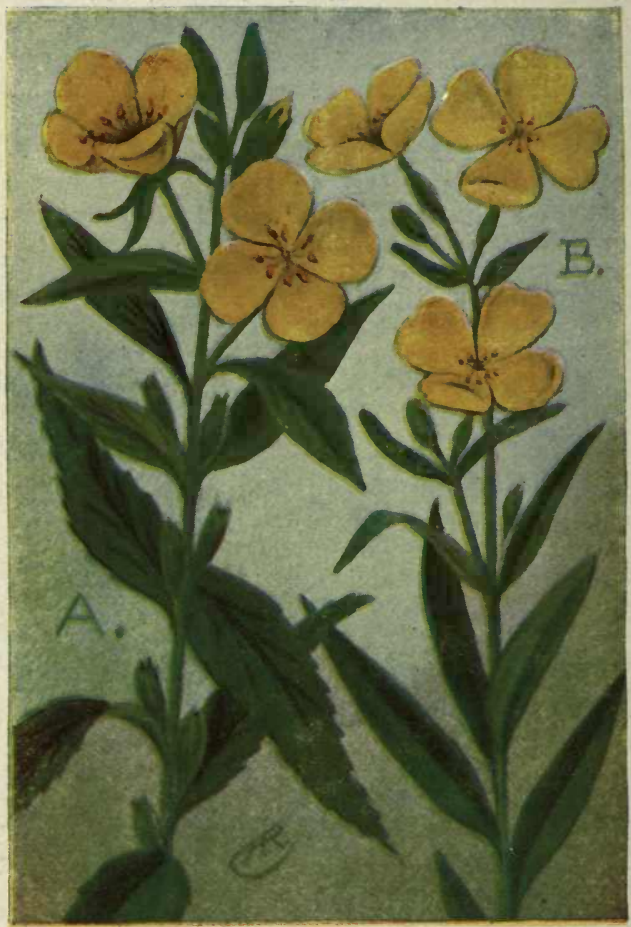

A. Evening Primrose. Oenothera biennis.

B. SUNDROPS.

Oenothera fructicosa. 
EVENING PRIMROSE (Oenothera biennis) is an exceedingly common biennial plant, so persistent and so profuse in its growth that it is often regarded as an obnoxious weed. Its common name was given it because of its nocturnal habits, the flowers spreading wide open at dusk and partly or wholly closing the next morning.

The stem is soft-hairy, quite stout and often very tall, ranging from 1 to 6 feet in height. It is usually simple, but sometimes branches, especially in the Fall. Both the stem and the leaves are rather coarse in texture; the latter are lanceolate, stemless and rough-edged or very slightly toothed. The flowers are seated in the angles of the upper leaves; they appear to be on stems, for the calyxtube is very long and slender, with the four lobes, or sepals, reflexed. The four, pale, lemon-yellow petals are large and rounded, the flower spreading slightly less than two inches; the eight stamens have golden-yellow anthers.

The lower buds open first, only a few at a time, so that usually we may find seed-pods seated among the leaves just below the flowers and undeveloped buds and leaves above. It is fertilized sometimes by bees in the daytime, but chiefly by night-flying moths. A large variety (grandiflora) is often cultivated and sometimes escapes. It is an European species with flowers measuring 3 or 4 inches across. The Primrose blooms in fields and roadsides, everywhere, from July to September.

SUNDROPS (Oenothera fructicosa) a somewhat similar, diurnal species, with a branched stem grows 1 to 3 feet high. The pale yellow flowers measure from $1 / 2$ to 1 inch across; they are in loose terminal clusters or from the angles of the upper leaves. The leaves are linear-lanceolate, slightly toothed. Common from Me. to Minn. and southwards. 


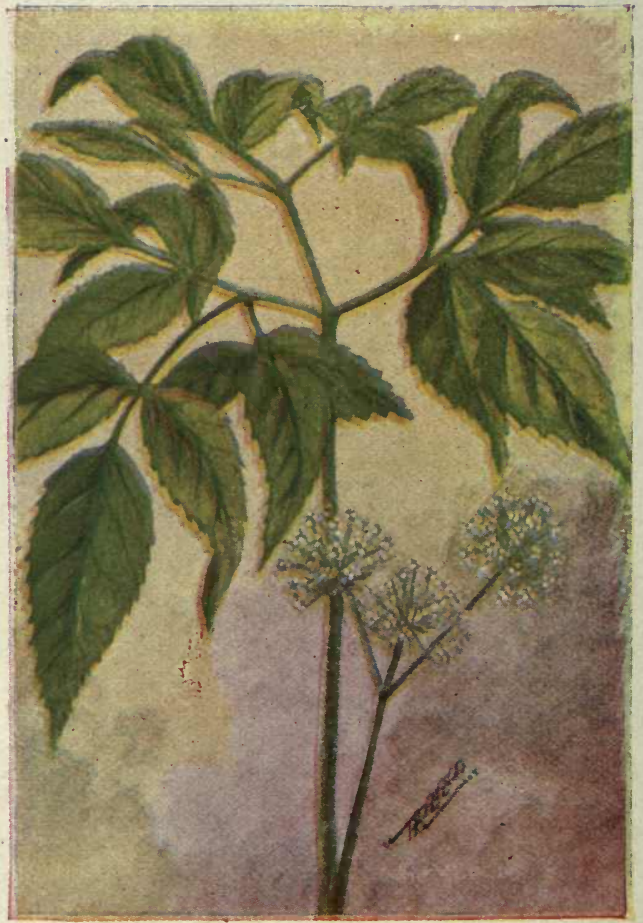

Wild Sarsaparilla.

Aralia nudicaulis. 


\section{Wild Flowers East of the Rockies}

\section{GINSENG FAMILY (Araliaceae).}

A family of herbs with compound leaves and usually perfect, tiny flowers in umbels or clusters.

WILD SARSAPARILLA (Aralia nudicaulis) has a single large, compound leaf on a long stem from the creeping, fragrant, aromatic root; the leaf is divided into three branching divisions, each containing five ovate, toothed leaflets. This single leaf is often mistakenly called three. The flowers are gathered into three, rounded umbels, on short pedicels, from the top of a long stem that joins the leaf-stem near its base; each cluster bears many, tiny, five-parted, greenish-white flowers with reflexed petals. It is a very decorative plant, common in moist woodland from Newfoundland to Minn. and southwards. It is often locally known as "Umbrella-plant" because of the manner in which the large leaf spreads protectingly over the round, flower clusters.

GINSENG (Panax quinquefolium) is well known as the plant that is collected and cultivated for the thick, fleshy, branching roots. Enormous quantities of these roots are annually shipped to China, where they command large prices because of supposed medicinal properties. The plant grows from 8 to 18 inches high. Three compound leaves, each consisting of five, ovatepointed, toothed, short-stemmed leaflets, radiate from near the top of the smooth stem. From six to twenty, tiny, 5-parted, yellowish-white flowers are in a round umbel, on a slender, upright peduncle above the leaves. It is found in rich, cold woods from Quebec to Minn. and South to Ala. and Mo.

DWARF GINSENG (Panax trifolium) is a tiny species from 4 to 8 inches high. It has a spherical root, slender stem, three leaves compounded of three leaflets each, and numerous, tiny white flowers in an umbel above them. Common in rich woods from $\mathrm{N}$. S. to Minn. and southwards. 


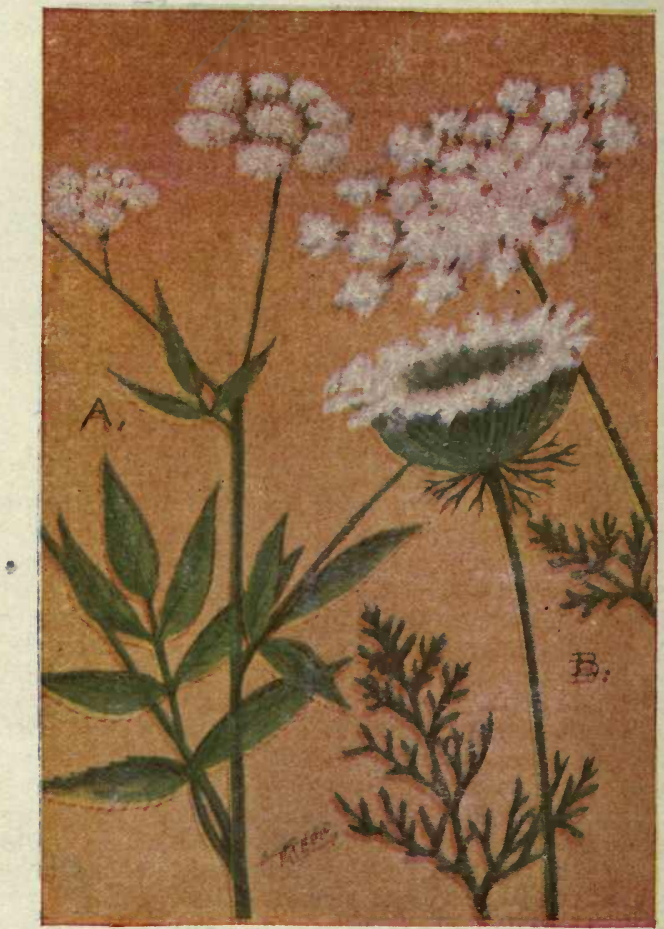

A. Water Parsnip.

Sium circutaefolium.

B. Wild Carrot; Queen Anne's Lace. Daucus Carota. 


\section{Wild Flowers East of the Rockies}

\section{PARSLEY FAMILY (Umbeliferae).}

A large family of herbs, usually with hollow stems, tiny, perfect or polygamous flowers in umbels or flattopped clusters and with deeply-cut, compound leaves.

WATER PARSNIP (Sium cicutaefolium) is a stout branching herb growing in shallow water. The rather weak stem is from 2 to 6 feet high. The alternating, compound leaves are very variable, but usually of from seven to fifteen, sharply-toothed, linear or lanceshaped leaflets. Flat, dome-shaped clusters, or umbels, of tiny white flowers terminate the upper branches. This species is very abundant throughout the country.

EARLY MEADOW PARSNIP (Zizia aurea) is a common roadside weed, or found along the borders of woods, swamps or meadows. Its rather weak appearing stems surprise us with their power of resisting when we try to break them. The leaves are divided into three parts, containing five or seven, lanceolate, toothed leaflets, each. The tiny golden-yellow flowers are arranged in terminal heads consisting of numerous wide-spread, little umbels.

WILD CARROT; BIRD'S NEST; QUEEN ANNE'S LACE (Daucus Carota) (EUROPEAN). While to flower lovers, this may appear to be the most beautiful species of the family, it is the most heartily detested weed with which the farmer has to contend. It is very prolific, and each individual plant strikes its roots deep into the ground, as though determined to defy extermination. It is a very near relative to, and by some supposed to be, the species from which our cultivated carrots descended. The fully opened flower clusters have an exquisite, lace-like appearance, while those half-opened are hollowed suggestively like a bird's nest; in the center of the cluster, is a tiny purple floret, all the others being white. 


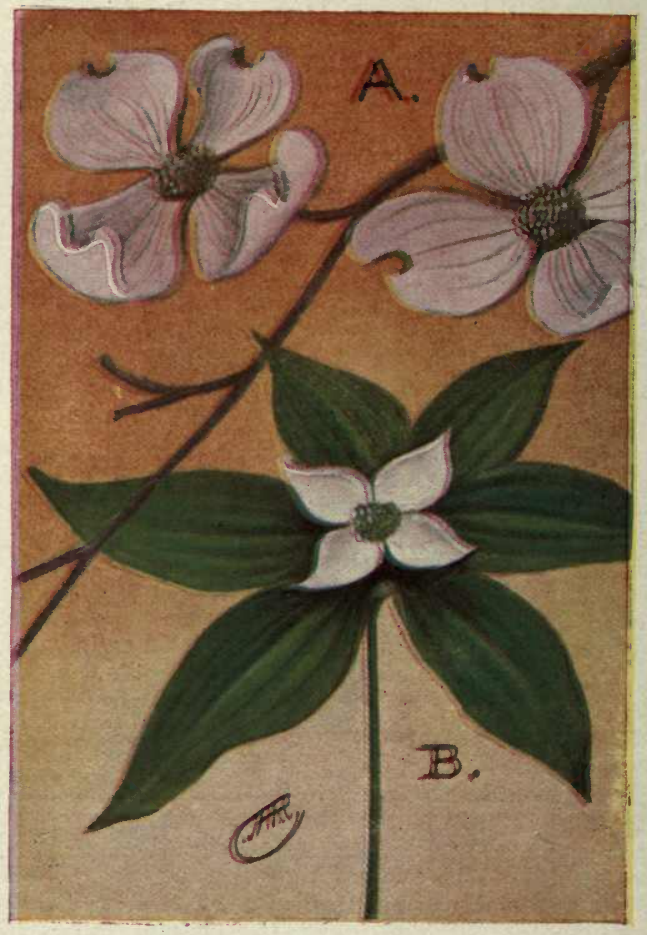

A. Flowering Dogwood.

Cornus florida.

B. Dwarf Cornell; Bunchberry.

Cornus canadensis. 


\section{Wild Flowers East of the Rockies}

DOGWOOD FAMILY (Cornaceae).

FLOWERING DOGWOOD (Cornus florida) is a tall shrub or tree, ranging in height from 7 to 40 feet. It is in reality outside the scope of this book, as we do not aim to include shrubs or trees, but Dogwood is so conspicuous in flower and so closely related to the following species, that it has been included. The large handsome flowers are in full bloom before or just as the leaves commence to appear. So profusely do the large white, flowers, measuring 2 to 4 inches across, cover the whole tree that the appearance, from a little distance, is as though the tree were mantled with snow.

The four, large, notched segments are not petals, but form the involucre and the real flowers are clustered at the center; they have four tiny greenish-white petals and numerous little stamens. This Dogwood is common in dry woods from Me. to Minn. and south to the Gulf.

BUNCHBERRY; DWARF CORNEL (Cornus canadensis) is really a dwarf as compared to the preceding, for it grows only from 4 to 8 inches high.

The stem is leafless except at the top, at which point, four to six leaves radiate; they are ovate-pointed, shining yellow-green and have five or more deep, parallel ribs. They usually grow in colonies, often so closely together that the leaves overlap and obscure the ground.

What appears like a singled large blossom seated almost within the whorl of leaves, is in reality a cluster of tiny, green-petalled, 4-parted flowers surrounded by four large greenish-white bracts; these pointed outer divisions form what is termed the involucre of the flowers.

In Fall a cluster of scarlet berries takes the place of the flowers, so the plant is attractive at all seasons. It ranges from Labrador to Alaska south to N. J., Ind. and Minn. 


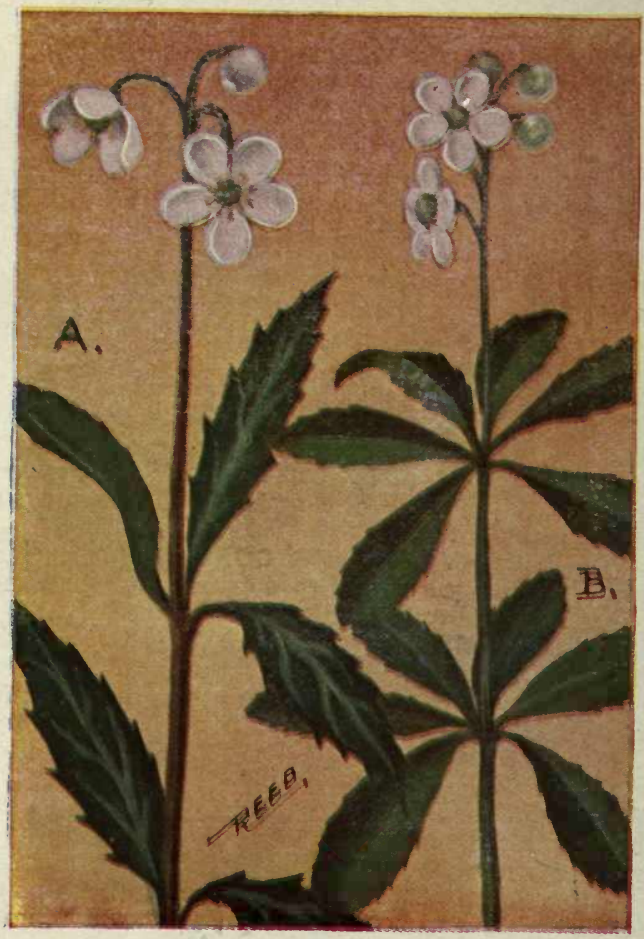

A. Spotted Wintergreen.

Chimaphila maculata.

B. Pipsissewa; Prince's Pine.

Chimaphila umbellata. 


\section{Wild Flowers East of the Rockies}

\section{HEATH FAMILY (Ericaceae).}

A family of shrubs or herbs having perfect and usually regular flowers, with four or five petals and the same number, or twice as many, stamens.

Divided into three sub-families, the Pyrola (Pyroloideae), the Indian Pipe (Monotropoideae) and the Heath (Ericoideae).

\section{PYROLA SUBFAMILY.}

SPOTTED WINTERGREEN (Chimaphila maculata) is a very handsome plant that we often come across in our rambles through rich woodland. It is a species one cannot mistake, for no other is like it. The stalk, that rises from 3 to 9 inches high, is of a ruddy color; the leaves are thick, smooth, irregularly toothed, lance-shaped, pointed and with conspicuous whitish streaks following the veins. In July and August, it bears one to five nodding flowers on long, erect peduncles above the topmost whorl of leaves; the five rosy or cream-colored petals have a frail, translucent, waxy appearance that characterizes members of this sub-family.

As would be imagined from its name, the leaves of this species remain on the plant through the winter. Because of this fact and their beauty, they are in demand for, and make excellent plants in ferneries. It ranges from Me., Ontario and Minn, south. ward to Ga. and Miss.

PIPSISSEWA; PRINCE'S PINE (Chimaphila umbellata) grows in similar localities and is generally more common than the last. Its leaves are usually in two whorls about the brownish stem; they are bright shining green, toothed, unspotted, pointed, but broadened towards the end. The flowers are similar to the last and are in a loose 2 to 8 -flowered umbel. The style is very short, with a five-parted gummy stigma; the ten stamens have double, purplish anthers. This species is found from N. S. to Ga. and west to the Pacific Coast. 


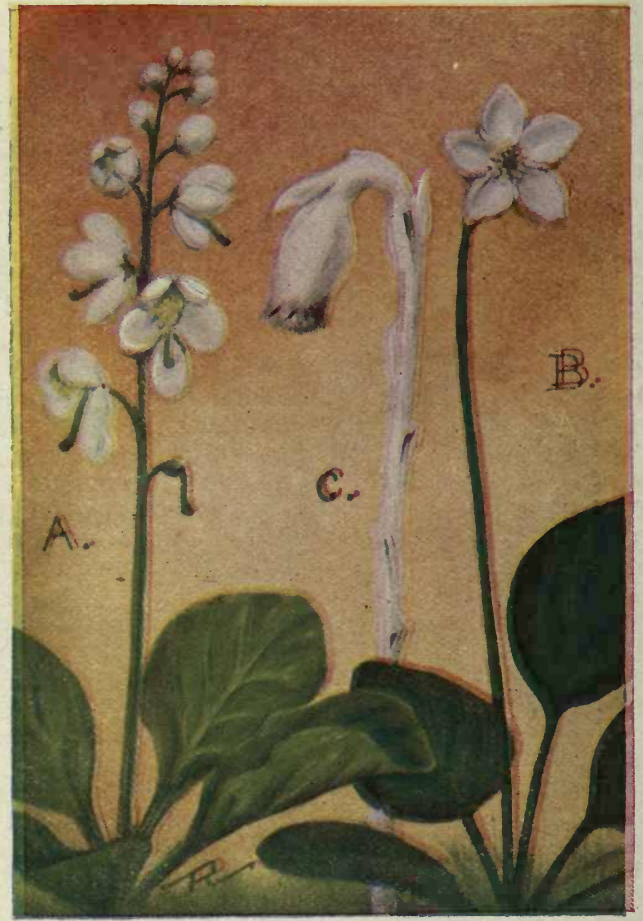

A. Shin-leaf. Pyrola elliptica.

B. One-flowered Pyrola. Pyrola uniflora.

C. Indian Pipe. Monotropa uniflora. 
SHIN-LEAF (Pyrola elliptica) is the most common of the Pyrolas. During the greater part of the year it is composed of a tuft of thin leaves, almost prostrate on the ground. The evergreen leaves are bright green, obscurely toothed, broadly elliptical and narrowing into long stems that clasp at the base. During May a long, smooth scape springs from the middle of the group of basal leaves to a height of 5 to 10 inches, bearing near its top a raceme of many buds; during June and July, these buds expand into nodding flowers; each has five waxy-white petals, a small, fiveparted, green calyx and a long curving pistil.

The name Shin-leaf was applied because the leaves were formerly used for, and supposed to cure, sores or bruises. It is common throughout the United States and southern Canada.

ONE-FLOWERED PYROLA (Moneses uniflora) externally closely resembles the preceding species; in reality it is intermediate between the Pyrolas and Chimaphila. The leaves, clustered at the apex of creeping subterranean shoots, are thin, rounded, shallow-toothed and on slender trough-shaped stems. The flower scape is from 2 to 5 inches high, has a few scale-like bracts, and at the summit bears, during June or July, a single nodding flower, with five ivorywhite petals, ten white stamens with large, two-pointed anthers and a prominent, club-shaped, green pistil. It ranges from Labrador to Alaska and south to $\mathrm{Pa}$. and Minn.

INDIAN PIPE, CORPSE PLANT (Monotropa uniflora) is a very peculiar, ghostly appearing plant found commonly in dimly-lighted, rich woods. It has no green foliage, just white bract-like appendages on its upright, white, cold, clammy stem. A single white flower nods from the top. It is parasitic, drawing its nourishment from living roots or decaying vegetable matter. Common throughout our range. 


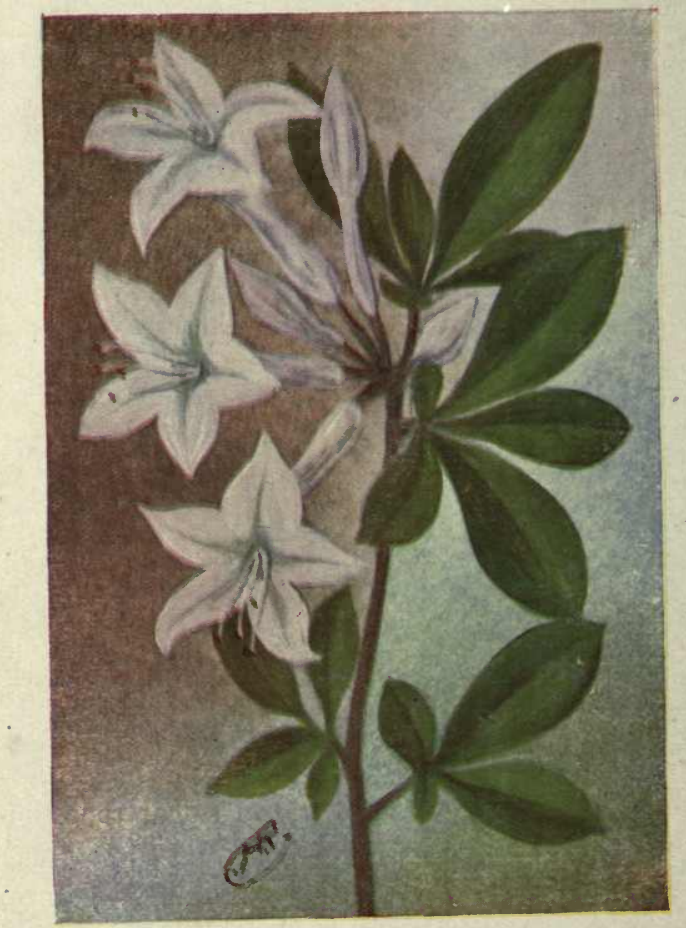

White Azalea; Swamp Honeysuckle. Rhododendron viscosum. 
SWAMP HONEYSUCKLE; WHITE AZALEA (Rhododendron viscosum) is a most beautiful swamp shrub with handsome, fragrant, white flowers. In low, wet swamps it is very common and blooms very profusely during June and July. The bush is from 3 to 8 feet in height and very branchy. The leaves are long-oval, broadest towards the blunt-pointed tip and narrowing to short stems.

The beautiful flowers are pure white, or rarely tinged with pink; the tube of the long corolla is covered with very sticky, brownish hairs, and terminates in five, large, pointed, spreading lobes. The stamens are very long, slender and white, and tipped with yellow anthers. The five-pointed calyx is very small and inconspicuous.

Besides being quite fragrant, the flowers secrete considerable nectar in the base of the tube, and are, consequently, favorites with many species of butterflies, moths and bees. Pilfering insects, like ants, are unable to reach the nectar tube, because of the very sticky exterior of the corolla. This species has the branchlets, and the margins and midribs of the leaves, bristly, this distinguishing it from the very similar Smooth Azalea (R. arborescens). The corolla tubes of both these species are much longer than the spreading lobes, this readily distinguishing them readily from the Pink Azalea in which the tube is about the same length as the lobes.

During the early time of their bloom, all the Azaleas bear, hanging among the fragrant flowers, peculiar, juicy, pulpy growths that are edible, as any well bred farmer's boy knows; he calls them May or Swamp Apples, but they are really modified buds and not fungus growths or caused by insects, as was formerly believed. These beautiful Azaleas are found from Me. to Ohio and southwards. 


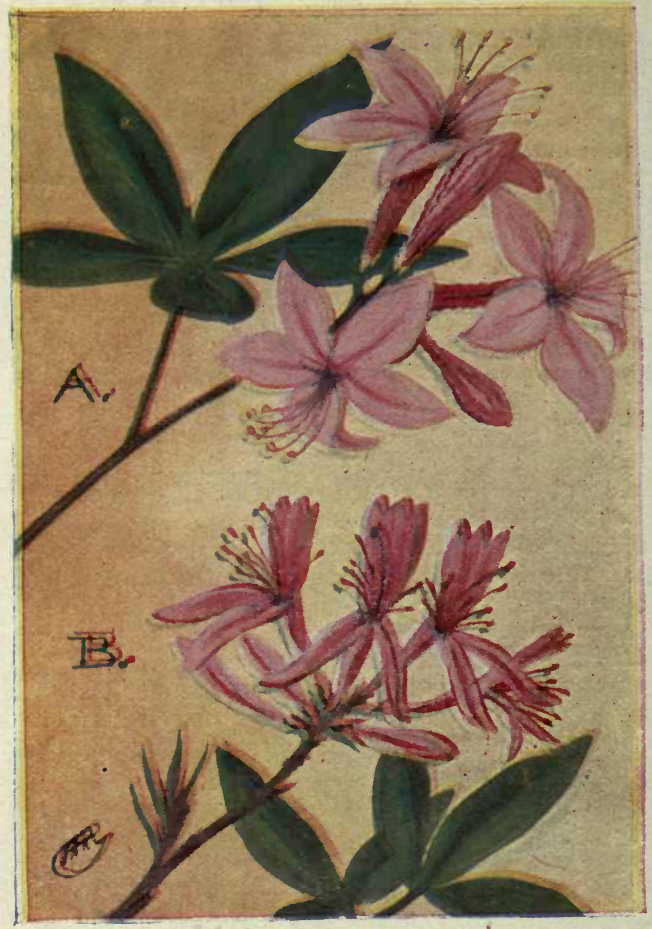

A. Pink Azalea.

Rhododendron nudiflorum.

B. Rhodora.

Rhododendron canadense. 
PINK AZALEA; PINXTER FLOWER, (WILD HONEY-SUCKLE) (Rhododendron nudiflorum) is one of our most interesting wild shrubs, interesting because the flowers bloom before the leaves appear, or just as they commence to grow, and because of the very beautiful colors its pink flowers impart to our swamps during April and early May. The flowers are practically the same in form as the white varieties, except that the corolla-tube is shorter. The color varies from just a rosy blush to a crimson pink. This added coloring seems to be at the expense of fragrance, for this species, while sweet scented, is not nearly as fragrant as the White Azalea. When the blossoms commence to fade, they loosen at the base and slip down on the long stamens, where they often remain suspended for several days before falling off.

Pink Azalea grows in open woods or swamps from Me. to Ill. and southwards.

FLAME-COLORED AZALEA ( $R$. calendulaceum) is a similar species well described by its names. Its large blossoms are orange, usually turning red, but are not fragrant, a still further loss of fragrance in conjunction with a brightening of color. The corolla tube is shorter than the lobes. This species is found from southern N. Y. to Ga.

RHODORA (Rhododendron canadense) is a beautiful member of this family, immortalized in verse by Emerson. It is a smaller shrub growing from 1 to 3 feet high. The flowers usually appear before the pale green, oblong leaves; the corolla is about one inch long, light magenta, and two-lipped. The upper lip is 3-lobed and the lower is nearly divided into two distinct, linear petals. They grow in thin clusters terminating the branches. Rhodora is found on damp hillsides and in swamps from Newfoundland to Quebec and south to N. J. and Pa., flowering during May and June. 


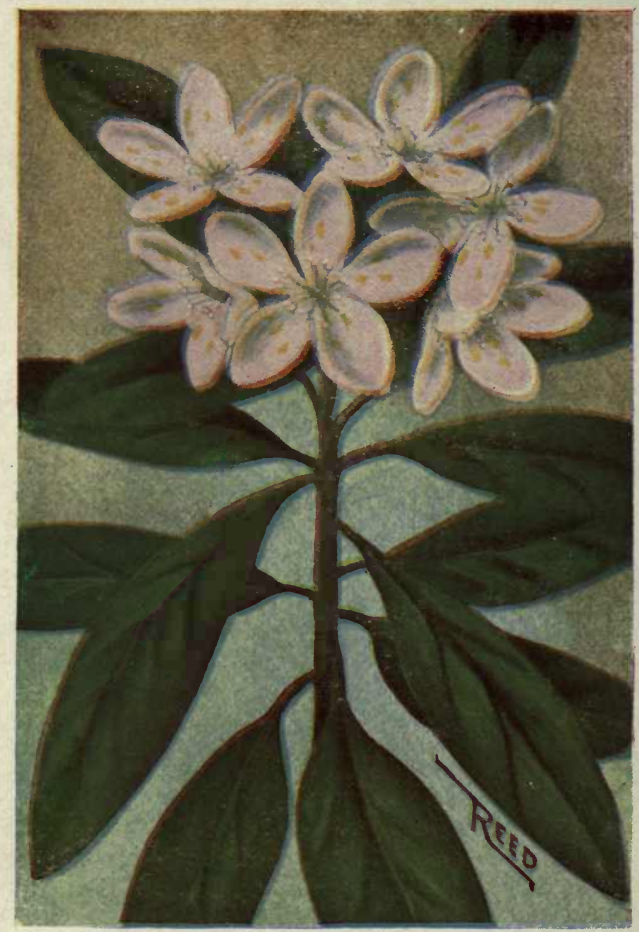

Great Laurel; Rhododendron. Rhododendron maximum. 


\section{AMERICAN RHODODENDRON; GREAT LAUREL} (Rhododendron maximum) is a large, tall and very ornamental shrub growing from 5 to 35 feet high. It is one of the most characteristic shrubs of the Allegheny Mountain region, where it grows in such profusion as to form almost impenetrable thickets. As it is a very hardy shrub and not injured by transplanting, it is very often used for decorative effects in parks and about private dwellings.

The oblong leaves are deep, glossy green, tough and leathery in texture and have a smooth, slightly rolled-under edge. They droop in the winter season but are wide spread in summer.

At the ends of the numerous branches, during June and July, are showy clusters of pink or white flowers. Each blossom spreads nearly two inches and is composed of five, broad, blunt-ended petals of a pink-white color, spotted with golden-orange. They have ten spreading stamens and a small pistil. The flowers are visited most often by the common bumblebee. Each flower stem is sticky to prevent crawling insects from visiting the interior of the blossom; such insects usually have smooth, shining bodies not capable of transferring pollen and are useless to the welfare of the plant.

Rhododendron is found in rich, hilly or mountainous woods, commonly from $\mathrm{Pa}$. to $\mathrm{Ga}$. but rarly northwards to Ontario and Nova Scotia.

MOUNTAIN ROSE BAY ( $R$. catawbiense) is a similar species found in the higher mountains from Va. to Ga. It has oblong, round-ended leaves and flowers with a broad, bell-shaped corolla of lllacpurple petals.

LAPLAND ROSE BAY (R. lapponicum) is a dwarf species with small elliptical leaves and a prostrate stem, both dotted with rusty scales, and small purple flowers. It is found from N. Y. and Me. to the Artic ${ }_{A}^{C}$ regions. 


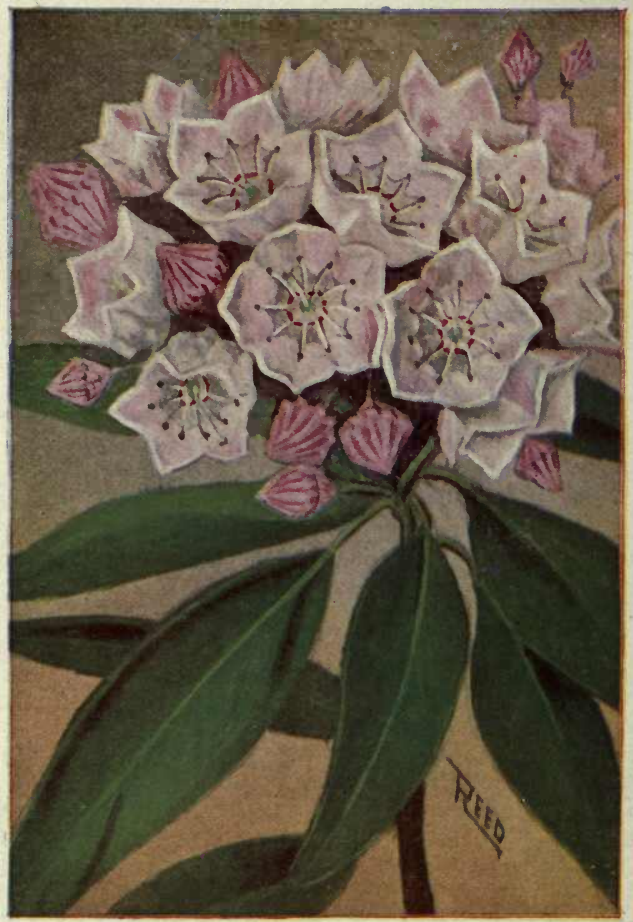

Mountain Laurel.

Kalmia latifolia. 
MOUNTAIN LAUREL; SPOON-WOOD (KaImia latifolia) is one of the most popular of our beautiful flowering shrubs. In the North it grows from 3 to 8 feet in height, but in the Southern States it often attains heights of 20 to 30 feet. Its evergreen leaves lend themselves very readily to decorative effects and are used in large quantities for wreaths, so many are used, in fact, that Laurel is becoming scarce near the larger cities of New England. Laurel often grows in dense thickets, so dense, in fact, that it is sometimes impossible to force a way through them.

The leaves are dark glossy green, pointed at each end and oblong in shape; they are arranged alternately along the branches and in dense terminal clusters. The flowers are very peculiar in their construction, the corolla being deep saucer or bowl-shaped, with five short, broad lobes; on the outside, around the bottom edge of the "bowl," are ten small humps, that inside the corolla form little pockets to receive the anthers of the slender white stamens, curving from the center of the blossom like the spokes of a wheel.

Both moths and bees visit these flowers in quest of the little supply of nectar that is secreted about the base of the greenish pistil. In order to get at it they alight right in the center of the flower; and pollen they may have brought from previous blossoms visited, is quickly entangled on the sticky stigma. As they successively insert their proboscis between the curved stamens, these become loosened from their little pockets and spring upwards, covering the under side of the visitor with a fresh supply of pollen to carry to another blossom. The flower stems are sticky so that only winged insects can get to the interior. Laurel is common from N. B. to Ont. and southwards. 


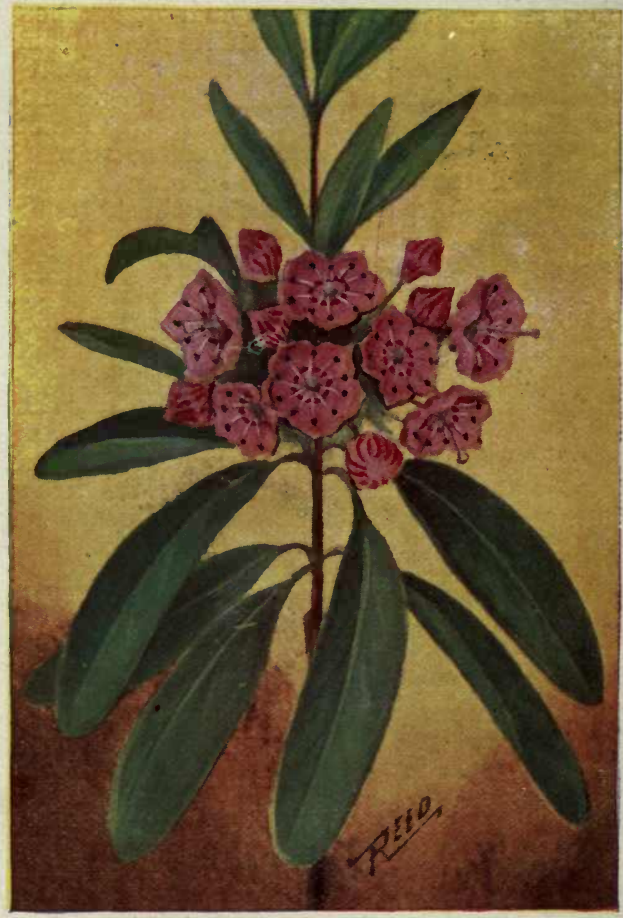

Sheep Laurel.

Kalmia angustifolia. 
SHEEP LAUREL; LAMBKILL (Kalmia angustifolia) is a small shrubby species, ranging from 8 to 36 inches high and is no less beautiful than the preceeding. Besides the common names given above, it is less often known as "Sheep Poison" and "Wicky," a rather sinister lot of names to be applied to a shrub with such handsome flowers.

All of the laurels have dangerous properties, the juices of the leaves being very poisonous. It is also claimed that honey made by bees, feeding on the nectar from laurel blossoms, is also poisonous. This species gets its many names, referring to its destructive effects on sheep, because it grows in abundance in pastures suitable only for the pasturage of sheep. The leaves of this small laurel look tempting but are very often fatal to the animals eating them.

The small, oblong leaves are rather closely set on the upright, woody stems either oppositely or in threes; they are bright green above and much paler on the under side, often spotted with rusty; the stem and the midrib is of a yellowish shade of green.

The handsome flowers are grouped in clusters about the middle of the branches or near the top, with a dense cluster of light green leaves, of new growth, just forcing its way above them. Their shapes, forms and mechanisms are about like those of the Mountain Laurel, but the color is a beautiful, deep pink; little red anthers fit snugly in the ten little pockets formed for them in the surface of the corolla. Sheep Laurel is common from Lab. to Ont. and southwards, blooming in June and July.

PALE LAUREL (Kalmia polifolia) is similar but distinguished by its two-edged branches, the whitish green under surface of the leaves and their rolledup edges. It grows from Lab, to Alaska and southwards. 


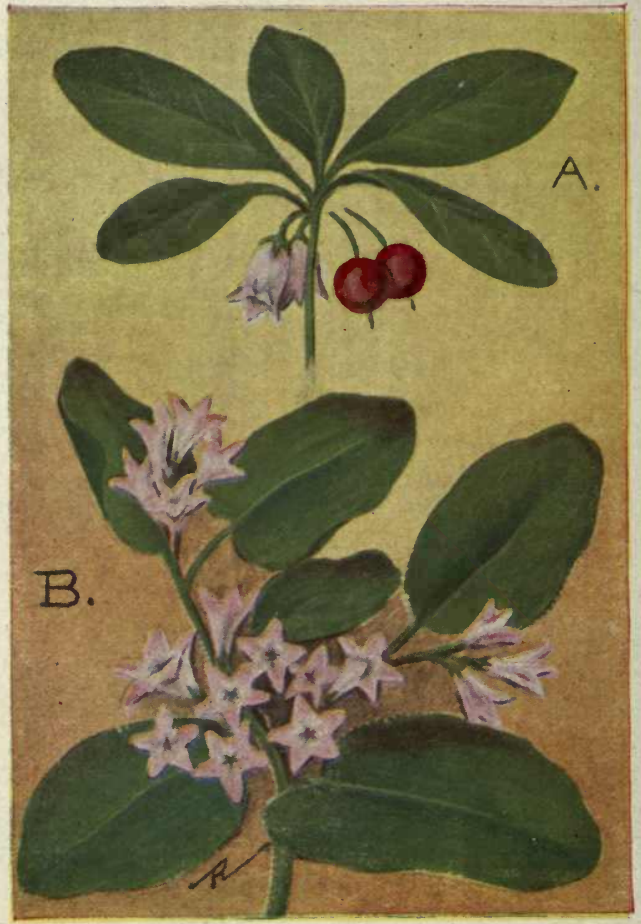

A. Wintergreen; Checkerberry.

B. Arbutus; Mayflower.

Epigaea repens. 
WINTERGREEN; CHECKERBERRY (Gaultheria procumbens). I doubt if there is a country boy or girl within the range of this plant, and it extends from Newfoundland to Manitoba and southwards to the Gulf, who is hot perfectly familiar with it. In Spring they search for "pippins," as they term the tender, young, yellow-green leaves of the new shoots that spring up on reddish stalks; the leaves have a very palatable, spicy, flavor, when they first appear. In Fall, children troop to the woods and gather the bright, luscious checkerberries, competing with one another to see who will find the plant with the largeest number of berries; ordinarily there are but two to a plant, but occasionally we may find five, six or even eight of them hanging beneath the sheltering leaves.

The leaves are all clustered at the top of the ruddy stem that grows from 2 to 5 inches high; those of adult plants are deep, shining green, ovate-pointed and very sparingly toothed. Usually two white, tubular, 5-notched flowers hang on slender peduncles, just beneath the spreading leaves, during July and August.

TRAILING ARBUTUS; MAYFLOWER (Epigaea repens). Probably no flower, especially in New England, is as eagerly sought nor as highly prized as the early blooming Mayflower. In fact its haunts are ravaged so thoroughly that one has to go farther from the city limits each year in order to find them. Arbutus is a creeping plant; the stems are tough, hairy and branched; they spread out along the ground for 6 to 15 inches from the root. The evergreen, alternating leaves are tough, oval, slightly heart-shaped at the base, net-veined and toothless. The flowers are in terminal clusters, opening in April and May. They are 5-parted, delicate pink and have a fragrance similar to that of the Water Lily. Arbutus grows throughout the eastern half of our continent on shady, rocky hillsides. 

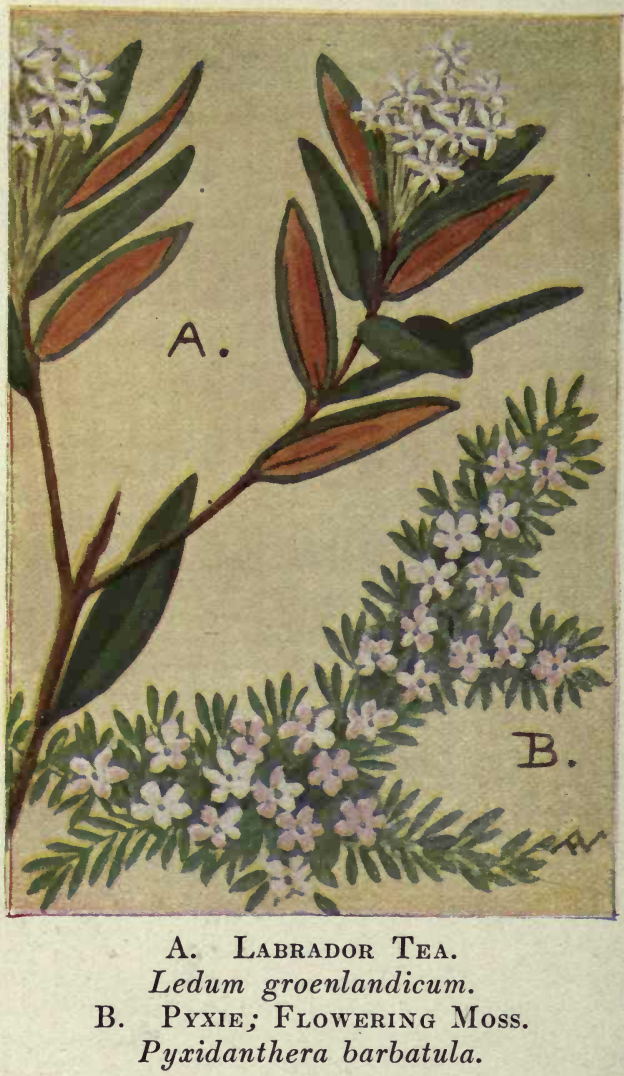
LABRADOR TEA (Ledum groenlandicum) is an erect shrub growing from 1 to 3 feet high. It is not uncommon in suitable places in the eastern half of Canada, and is found rarely in mountains south to Conn., Pa., and Minn.; its habitat is in bogs or damp thickets. The narrowly oblong leaves are green above, have the edges rolled back and are covered beneath with a rusty wool. They alternate along the stems the same as do those of the laurels, becoming more crowded towards the ends of the branches. The small white flowers are clustered at the ends of the branches; each has a small five-toothed calyx, five petals and five or ten long stamens surrounding the short pistil.

LEATHER LEAF (Chamaedaphne calyculata) is a low, much-branched shrub with small, obtuse, flat, leathery leaves. Small white flowers grow in the axils of the upper leaves, forming one-sided leafy racemes. It is found in bogs from Labrador to British Columbia and south to Ga., Ill. and Minn.

\section{DIAPENSIA FAMILY (Diapensiaceae).}

A small family of low herbs, or tufted moss-like shrubs closely related to the heath family, the chief distinction being the insertion of the stamens on the corolla.

PYXIE; FLOWERING MOSS (Pyxidanthera barbulata). Pyxie is a very attractive moss-like shrub found commonly growing in the pine barrens of the southeastern states, from N. J. to ... N.. C... The branches are prostrate and creep along the ground for 6 to 10 inches from the roots.

Each branch is very thickly set with tiny, stiff, lance-shaped leaves less than half an inch in length. The numerous, tiny, white or pink flowers are seated on the stem, growing from the angles of the leaves; they have five, broad-ended petals and attached between each of them is a curious, short, stout stamen. 


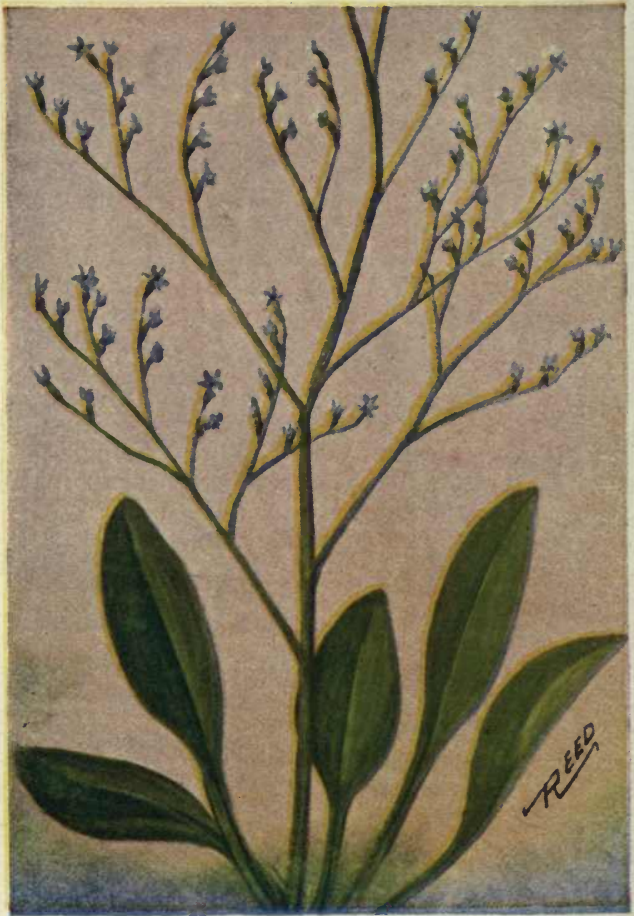

Sea Lavender; Rosemary. Limonium carolinianum. 


\section{LEADWORT FAMILY (Plumbaginaceae).}

Seaside plants with perfect, regular flowers in 1-sided racemes or spikes; 5-parted and with plaited calyx.

\section{MARSH ROSEMARY; SEA LAVENDER (Limon-} ium carolinianum) is a very characteristic plant of the seashore; it is found very commonly in salt marshes along the Atlantic coast from Labrador to Florida, and along the Gulf to Texas.

The plant has a thick, woody, very astringent root, from which grows a single naked stalk. This stem divides into numerous branches and branchlets, all destitute of leaves and spreading out so that the appearance of the whole plant is that of a very diminutive tree. The leaves all radiate from the root at the base of the flower stalk; they are spatulateshaped, thick, almost smooth-edged, have a prominent mid-rib and are on long stems.

At the end of each branchlet is a slender, 1-sided raceme of tiny buds. From July until September these open out into tiny lavender flowers with five tiny petals, each coming from a 5-toothed, ribbed calyx.

Large portions of marshes are often covered with Marsh Rosemary, growing so closely together that the branches of the different plants interlock; when these are in flower, they give a purplish misty appearance to the whole marsh.

The little Sharp-tailed Sparrow is a common bird of the New England salt marshes. I have often found their little homes, built of woven grasses, attached to the marsh grass and sheltered by little patches of seaweed that had lodged in the branches of Marsh Rosemary during high spring tides.

If picked in the early stages of its bloom, Sea Lavender retains the color of its flowers when dried and is often used for decorations in vases. 


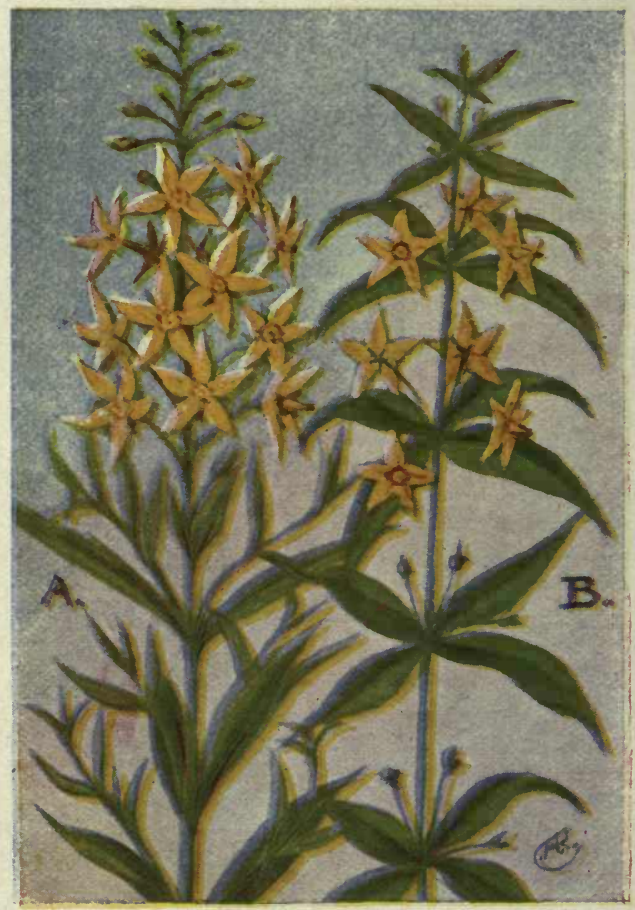

A. Yellow Loosestrife. Lysimachia terrestris. B. Four-leaved Loosestrife. Lysimachia quadrifolia. 


\section{Wild Flowers East of the Rockies}

\section{PRIMROSE FAMILY (Primulaceae).}

A family of herbs having regular perfect flowers and simple leaves, arranged oppositely, alternately or whorled about the stem.

YELLOW LOOSESTRIFE (Lysimachia terrestris). From July until September, our swamps are brightened by the golden-yellow wand-like spikes of Loosestrife, swaying on tall, slender leafy stems. We often find this species growing in company with the following, but the present one is fond of very wet places and is most abundant in boggy swamps that are impenetrable unless shod especially for it. Yellow Loosestrife has a tall, slender, simple stem from 8 to 24 .inches high. The leaves are pointed-lanceolate, stemless and crowded along the stem, either oppositely or alternately. The flower spike is long and contains many buds on slender pedicels; they open, a dozen or more at a time, from the bottom of the spike upwards, each plant thus being in bloom for several weeks. Each flower has five, pointed goldenyellow petals, each with two small reddish brown spots near the base; the stamens and pistil project in a cone-like cluster, the stigma being so far removed from the anthers that self fertilization is not apt to occur. The setting of the seed depends largely upon small bees that visit the flowers for pollen. This Loosestrife is abundant from Newfoundland to Hudson Bay and southwards.

FOUR LEAVED LOOSESTRIFE (Lysimachia quadrifolia) is also a very common species found in low land in about the same range. The flowers are very similar but each petal has a single large spot of reddish brown at its base instead of a double one; the flowers appear from the axils of the upper leaves. The pointed, lanceolate leaves are whorled about the stem usually in groups of fours, occasionally more or less. 


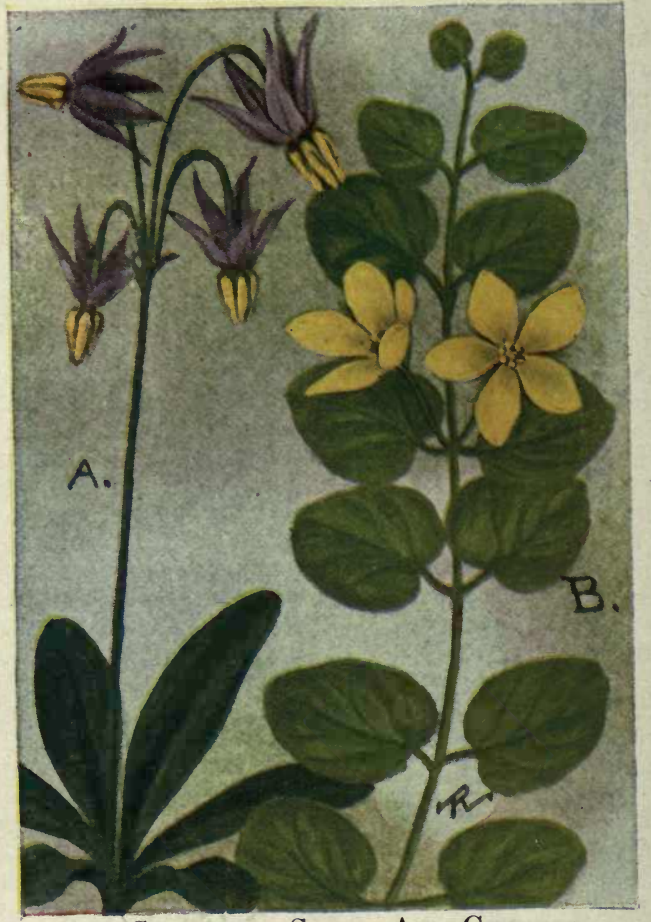

A. Shooting Star; Am. Cowslip.

Dodocatheon meadia.

B. Myrtle; Moneywort.

Lysimachia Nummularia. 
SHOOTING STAR; AMERICAN COWSLIP (Dodecatheon Meadia) is a western species that grows in open woodlands and on prairies from $\mathrm{Pa}$. and $\mathrm{Md}$. to Manitoba and southwards through the Mississippi Valley.

The leaves are all in a tuft radiating from the base; they are oblong, bluntly-pointed and taper into troughlike stems. From the center of this cluster of leaves rises a bare flower stalk, 8 to 20 inches tall, branching at the summit into several slender, curving peduncles, each suporting a single nodding flower.

The flowers have five, light magenta, pink or even white petals each sharply reflexed and with purplish spots near the bases. The stamens project from the throat of the flower, the five golden anthers forming a conspicuous cone, within which is the slender pistil. The pistil matures before the anthers so that cross-fertilization is necessary and is performed by bees, that, in endeavoring to reach the little store of nectar at the bottom of the flower, must force their tongue between the anthers and come in contact with the stigma. Shooting Star blooms in April and May.

MONEYWORT; MYRTLE (Lysimachia Nummularia) (EUROPEAN) is a very dainty and beautiful trailing or creeping vine, often spreading over largesurfaces of ground. It is found in this country as an escape from cultivation; it is a most beautiful plant for rockeries and does well in the house in hanging pots, the long slender, beautifully leaved branches drooping over the edge of the pot, giving a very decorative effect. When in bloom, its beauty is greatly enhanced by the large, yellow, star-like flowers. The leaves, that grow oppositely all along the stem, are almost round; it is from their shape and the fact that they are about the size of the English twopence that they originally received the name of Moneywort. It blooms from June until August. 


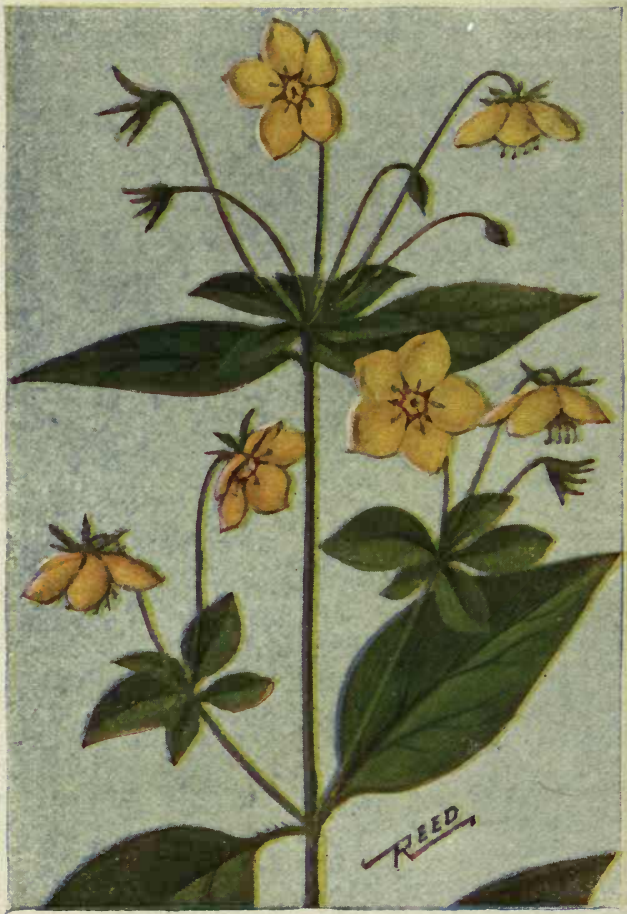

Fringed Loosestrife. Steironema ciliatum. 
FRINGED LOOSESTRIFE (Steironema ciliatum) Fringed Loosestrife is a very branching herb not at all like the other varieties. The smooth stem rises to heights of from 12 to 24 inches. The species receives its specific name Fringed, (ciliatum,) because of the fine hairs on the upper side of the leaf stems, the rest of the plant being smooth.

The smooth, light green leaves are lance-shaped and pointed, on short petioles or stems growing oppositely an the plant stem. The flowers grow on slender pedicels from the axils of the terminal leaves; the golden-yellow corolla is divided into five ovate lobes, each terminating in a sharp, twisted or mucronate point; around the center of the corolla is a reddish brown ring, formed by small spots at the bases of the five lobes. The pale green pistil in the center is surrounded by ten stamens, five being fertile and the other alternating ones being abortive.

The sight of any familiar plant usually recalls to our minds some particular incident connected with it, usually the place in which we have previously found it most abundantly. The present species always brings before me a certain swamp, regarded as utterly worthless by persons not interested in living creatures or plant life, but a veritable paradise for the botanist. entomologist and ornithologist. I have never seen the present species growing as abundantly anywhere as in this swamp.

Fringed Loosestrife is common in low ground and thickets from Newfoundland to British Columbia southwards to the Gulf of Mexico.

S. Ianceolatum is a similar but more slender speies with narrow leaves and smaller flowers, the latter measuring about one-half inch across. It is found from Me. to Minn. and southwards in the same habitats as the preceding. 


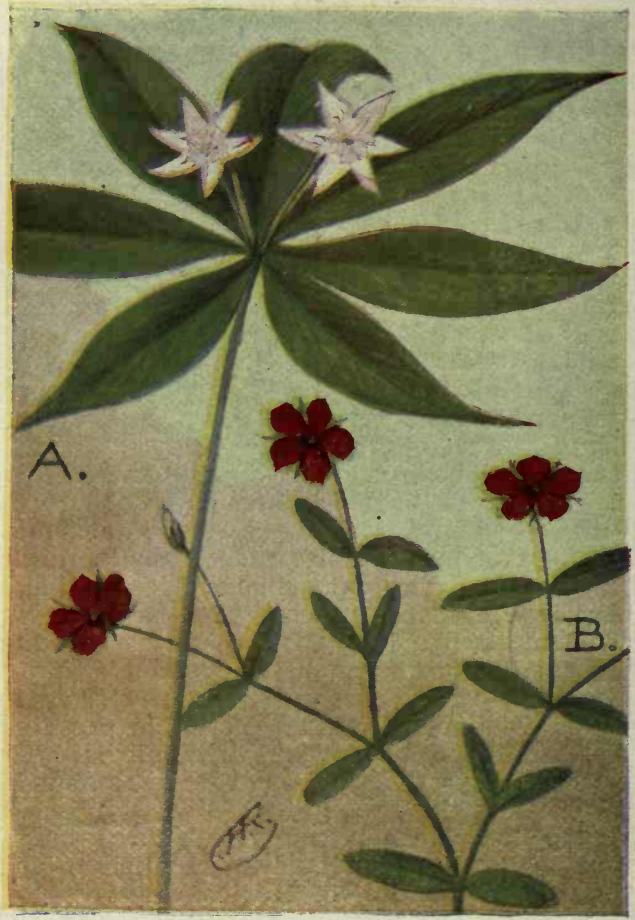

A. Star Flower.

Trientalis americana.

B. Pimpernel.

Anagallis arvensis. 


\section{Wild Flowers East of the Rockies}

STAR FLOWER (Trientalis americana) is a very dainty little plant often called the "Star Anemone," because of its color, the position of the flower above the whorl of leaves and the fact that it is often found blooming very closely to the Anemones.

The perennial rootstalk is long and horizontal and throws up a single, smooth, slender stalk from 3 to 9 inches high; at the top of this stalk is a whorl of from five to ten, thin, smooth, veiny light green leaves; they are lance-shaped and sharply pointed. During May and June a solitary blossom, (rarely two,) appears above the whorl of leaves on a very slender pedicel. The delicate white petals are sharply pointed and range from six to eight in number; the wide-spread stamens have tiny golden anthers that mature later than the little stigma. Fertilization is effected by the visits of small bees that visit the attractive little flower for pollen. The Star Flower is found in thin woodland from Labrador to Manitoba and south to Va., Ill., and Minn.

\section{PIMPERNEL; POOR MAN'S WEATHER-GLASS} (Anagallis arvensis) (EUROPEAN) is a flower readily identified; in the first place there are very few red flowers to be found and no others with the shade of red of this one, a salmon or coppery-red. The square stem is smooth, slender and rather weak, often lying prostrate on the ground. The small oval leaves clasp the stem oppositely.

The flowers grow singly, either on slender pedicels terminating the stem or from the axils of the outer leaves. They are five-parted, wheel-shaped, each division being finely toothed at its apex. They are very sensitive, opening only in sunshine and closing quickly when the sun is obscured, and usually at four o'clock anyway. It is found in waste sandy places especially near the coast. 


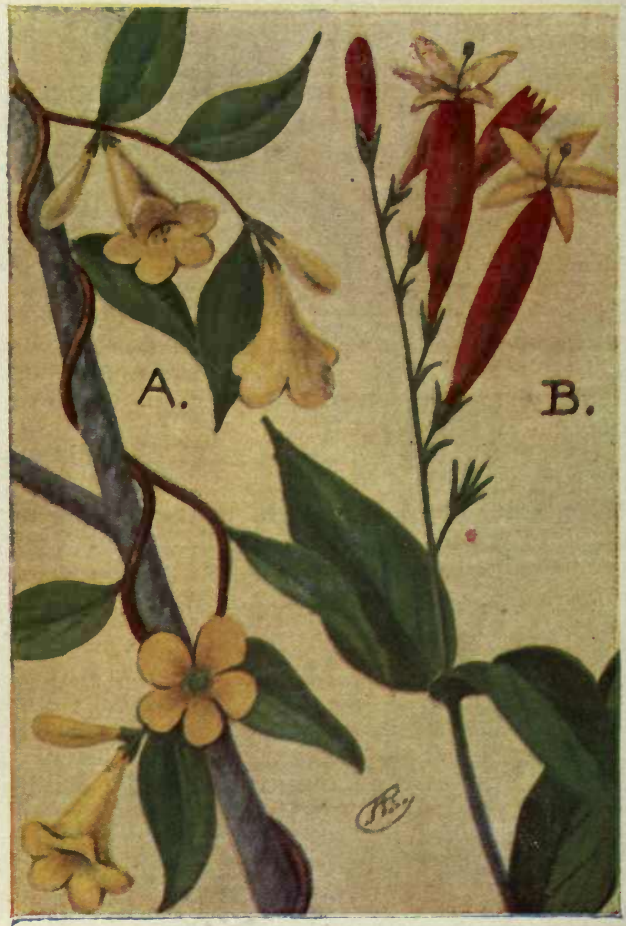

A. Yellow False Jessamine. Gelsemium sempervirens.

B. Indian Pink; Pink Root. Spigelia marilandica. 


\section{Wild Flowers East of the Rockies}

\section{LOGANIA FAMILY (Loganiaceae)}

A small family of herbs, shrubs or trees with entire-edged, opposite leaves, usually with stipules, and with regular, perfect, four or five-parted flowers; forming a connecting link between the Gentian, Dogbane and Rose Families.

YELLOW FALSE JESSAMINE (Gelsemium sempervirens.) This beautiful vine is very common in the Southern States where it may be found climbing the trunks of trees, trailing over bushes or even creeping over the ground. During March and April, large, handsome yellow flowers appear in one-sided spikes. The blossoms are tubular-funnel-form and range from one to two inches in length; the opening is spreading and divided into five lobes. The five stamens are tipped with saggittate anthers and the two slender pistils have two-parted stigmas.

The ovate-pointed leaves, that grow oppositely on short petioles, are evergreen; the short flower spikes grow from their axils. The stem is smooth, woody and twining. This species ranges from Va. to Fla. and Texas.

INDIAN PINK; PINK-ROOT (Spigelia marilandica) is an erect herb found in rich woods from Ohio and $\mathrm{Ky}$. to Fla. and Texas. It is a perennial with a simple stem rising from 1 to 2 feet high. The pointed, ovate-lanceolate leaves are seated oppositely on the stem, united by stipules. The flowers grow in a short, one-sided spike; the corolla is tubular-funnel-form, 5-lobed at the end and about one or two inches in length. The inside of the tube is a bright yellow and the outside a dull red. The five stamens, with their linear anthers, are long and appear beyond the end of the tube. The single style is slender and hairy above.

The roots have a pink juice that may be used for coloring, a property instrumental in giving the plant its common names. 


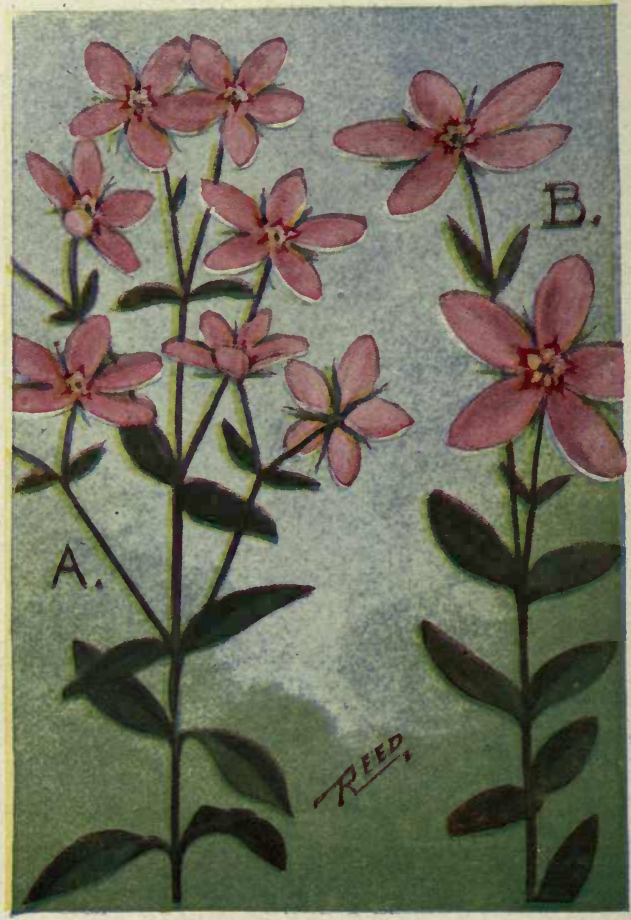

A. Rose Pink. Sabatia angularis. B. Sea Pink. Sabatia stellaris. 
GENTIAN FAMILY (Gentianaceae).

A family of beautifully flowered herbs having smooth stems and simple, opposite and sessile leaves. They also agree in having regular, perfect flowers.

ROSE PINK (Sabatia angularis) is the most widely distributed of the Sabbatias. Whereas the rest of the tribe are confined in a range very close to the seacoast, this species is commonly found in rich ground in all the states from the Mississippi River to the Atlantic. It is found most abundantly in meadows or along ditches, but also grows in comparatively dry land too. Its period of bloom is during July and August.

Rose Pink is a handsome plant when in bloom; the stem is square and grooved, branches considerably and rises 2 to 3 feet high. The ovate-lanceolate leaves are stemless and seated oppositely on the stem. The branches usually divide near their ends, each division bearing a beautiful flower about an inch across. At the center of the five-parted, pink corolla is a yellow-green star, a feature that is quite characteristic with members of this family. The calyx is composed of five very narrow sepals.

The roots have very bitter properties that are of use medicinally; because of the diligence with which it is hunted for the sake of these roots, it is yearly growing less abundant.

SEA PINK (Sabatia stellaris) is a beautiful, slender species common on salt marshes from Me. to Fla. The pink flowers grow singly at the ends of the slender branches. Like that of the last species, the center is yellow-green but is often edged with a deep crimson which adds greatly to the attractiveness of the blossom. The oval leaves are very small, almost bract-like, at the ends of the branches. 


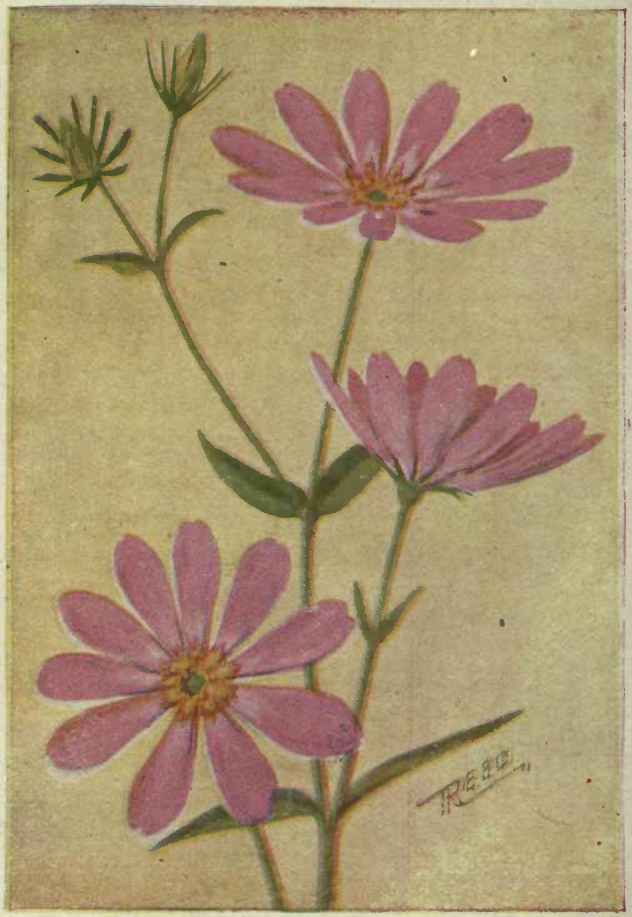

Sabbatia.

Sabatia dodecandra. 
LARGE MARSH PINK; SABBATIA (Sabatia dodecandra) is the largest flowered and the most beautiful species of this genus; in fact, it is one of the most delicately beautiful flowers of our wild flowers.

During July and August, along the Atlantic coast, we sometimes find brackish ponds, the shores and muddy flats of which have a ruddy glow owing to the number of these large attractive blossoms that appear. The stems are slender and wiry, and but little branched; they attain heights of 1 to 2 feet, each branch bearing usually but a single blossom.

The flowers measure from two to two and one-half inches across; the nine to twelve petals are a delicate rose color and each has, at its base, a yellowgreen spot margined by a three-pointed ochre or crimson border. The corolla has a regular, symmetrical wheel-like apearance, the petals making the spokes and the yellow center forming the hub. The calyx is composed of linear sepals to the same number as the petals. The stamens are quite widely separated from the slender style so that self-fertilization is hardly to be expected. Of course such beautiful flowers have hosts of insect admirers, most beneficial of which are some of the bee-like flies that are usually to be found about them.

SLENDER MARSH PINK (S.'gracilis) is very similar to stellaris, but the stem is very slender and the leaves are linear. The flow.ers are about the same size, with the petals averaging a trifle more narrow. The linear sepals are fully as long as the petals, with which they alternate. This species is found along the coast from Conn. to Fla.

LANCE-LEAVED SABBATIA (S. lanceolata) is a narrow-leaved variety found in pine barrens from $\mathrm{N}$. J. to Fla. The flowers terminating the slender branches are white, star-like and about one inch across. 


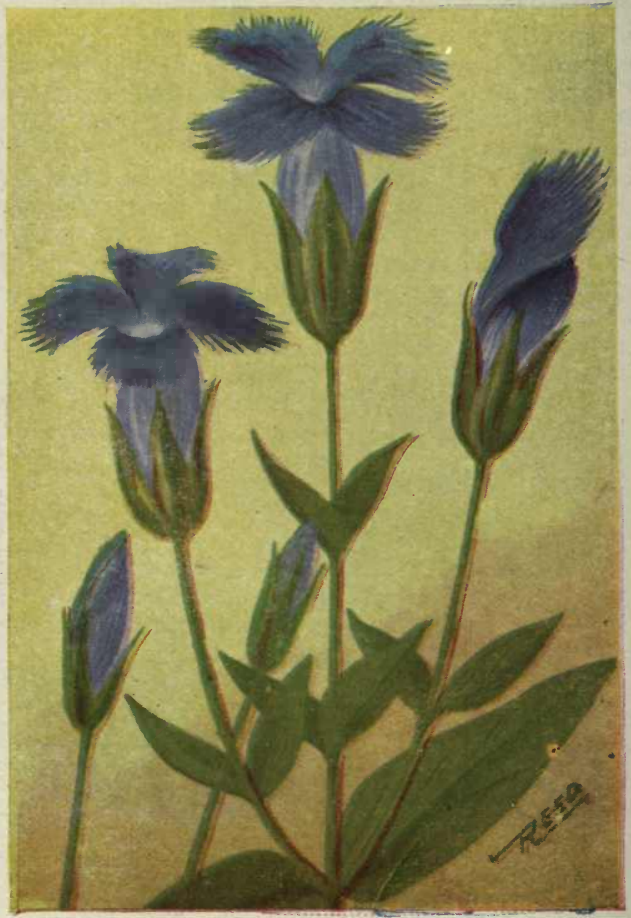

Fringed Gentian, Gentiana crinita, 
FRINGED GENTIAN (Gentiana crinita), because of its exquisite beauty and comparative rarity, is one of the most highly prized of our wild flowers. Surely it needs no introduction to our readers for has not Bryant immortalized it in his verse:

"Thou waitest late, and com'st alone

When woods are bare and birds have flown,

And frosts and shortening days portend

The aged year is near his end."

"Then doth thy sweet and quiet eye

Look through its fringes to the sky,

Blue-blue -as if that sky let fall

A flower from its cerulean wall."

The Fringed Gentian is rather a fickle plant; we may find it in a certain locality one year and then search in vain for it for the next few years. It is an annual and, unless the seed is properly set and conditions favorable, we will fail to find it next year even though it be abundant in certain places this. The stem is stout, stiff and branching, each branch being erect and terminating in a bud. The yellowgreen leaves are ovate-lanceolate, seated oppositely on the stem.

The calyx is angular, has four sharp points and is a bronze-green in color. During September and October we may find these blossoms fully expanded, delicate, vase-shaped creations with four spreading deeply-fringed lobes bearing no resemblence in shape or form to any other American species. The color is a violet-blue, the color that is most attractive to bumblebees, and it is to these insects that the flower is indebted for the setting of its seed. The anthers mature before the stigma is developed so that self-fertilization is impossible. The flowers are wide open only during sunshine, furling in their peculiar twisted manner on cloudy days and at night. In moist woods from Me. to Minn. and southwards. 


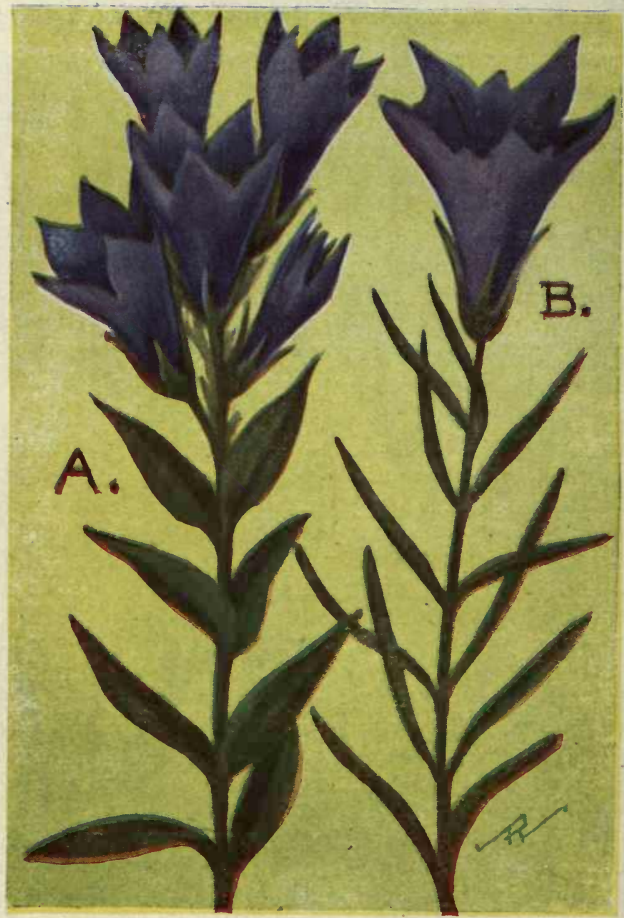

A. Downy Gentian.

Gentiana puberula.

B. Solitary Gentian.

Gentiana porphyrio. 
DOWNY GENTIAN (Gentiana puberula) is a handsome species springing from a perennial root, the simple, straight stem, rising from 8 to 18 inches high; the stem is usually rough and slightly hairy. The light green leaves are stiff and seated oppositely on the stem. The flowers are borne in terminal clusters or, sometimes, from the axils of the upper leaves; they are bell-shaped with five triangular, slightly spreading lobes. In color they are brilliant violet blue. The sharply toothed calyx is less tnan half the length of the tube of the corolla; it is quite rough to the touch.

Downy Gentian is common in dry fields and on prairies from $\mathrm{Pa}$. to $\mathrm{Ga}$. and west to Minn. and Mo., flowering during September and October.

SOLITARY GENTIAN (Gentiana Porphyrio) is a pretty little species growing in moist places from southern N. J. to Fla. The simple, slender stem ranges in height from 6 to 15 inches and bears at the summit a solitary, erect, bell-shaped flower, of a light ultramarine blue color; the five, spreading lobes are notched at their bases. The flower is very large compared to the stem and leaves of the plant it grows upon; the blossom measures from 2 to 2 1-2 inches long, which is about the length of linear leaves that are oppositely set on the stem.

AGUE-WEED (Gentiana quinquefolia) is a smaller and more common Gentian. It grows on moist hillsides from Me. to Ill. and southwards. It is an annual with a ridged, four-sided stem growing 8 to 22 inches high. The leaves are stiff, pointed and slightly clasping at their bases. The violet blue flowers are clustered at the end of the stem usually in fives, although sometimes we may find from two to seven in a group. The five lobes have sharp bristle-like points. All the Gentians have bitter juices that are used medicinally. 


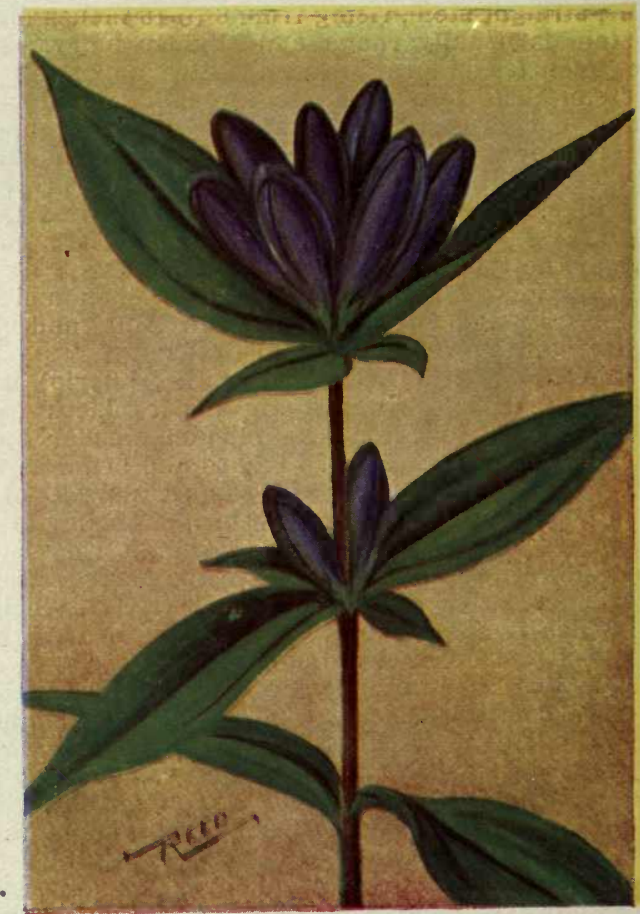

Closed Gentian; Bottle Gentian. Gentiana Andrensii. 
CLOSED GENTIAN; BOTTLE GENTIAN (Gentiana Andrewsii) is the most abundant of all Gentians. It is handsome but lacks the subtle beauty of the Fringed Gentian, the beauty that leads one to tramp miles in quest of it, and that, in time, is sure to exterminate a species. Again, the present species is a perennial and such plants have a tremendous advantage in the struggle for existence, over those whose roots last but a year and then die. The flowers of the Closed Gentian are as peculiar in their way as those of the Fringed are in theirs. It is remarkable because the five parts of the corolla never spread, the flower remains closed. The flowers are crossfertilized by the common bumblebee. He knows there is a supply of nectar at the bottom of each blossom and he has the wits and the strength to get at it. Slowly, but surely, he is able to force the closed lobes apart until his body is half concealed in the "bottle", and he is able to reach the bottom. As he leaves the flower he is certain to scrap off quantities of pollen on his head and almost sure to leave some of it on the receptive stigma of the next flower visited.

The stem is smooth and simple; it grows from 1 to 2 feet high. The leaves are rather large, ovatepointed and narrowed into very short clasping stems. The flowers grow in terminal clusters, set in the axils of the last pairs of leaves. They are deep, bright blue at the outer ends and shade to nearly white at the bases. The younger flowers, those that have not matured or had the nectar drained from their bases, are lighter colored than the old flowers. The distinction between the two is very evident to the bees that visit them, for they never make the mistake of entering a blossom that has already been drained. Closed gentian grows in moist places, often along brooks, from Me. to Manitoba and southwards. 


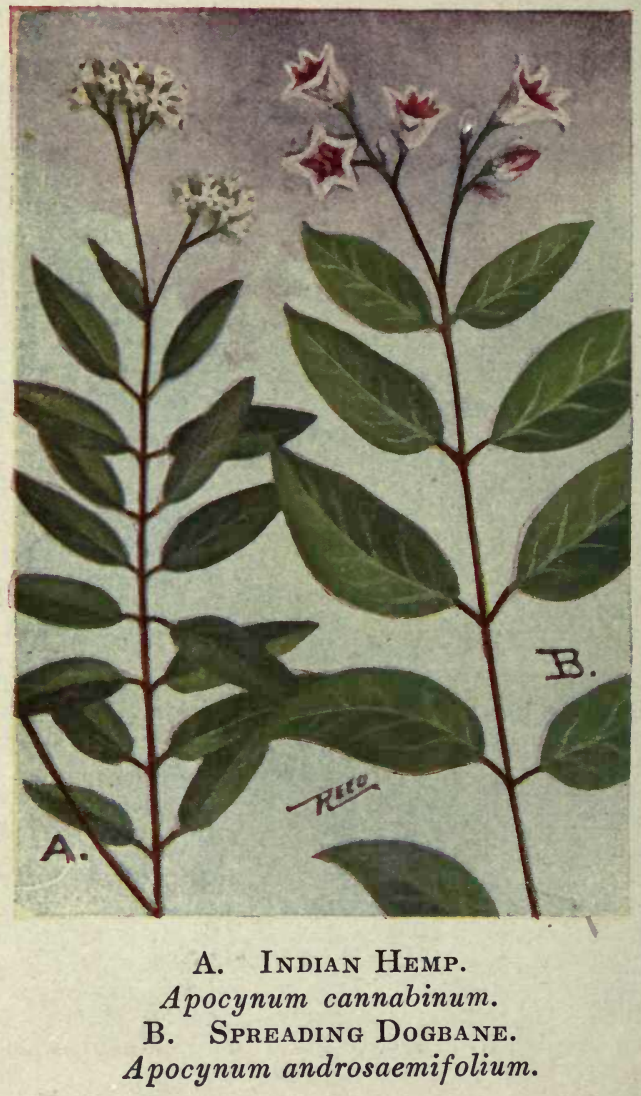




\section{Wild Flowers East of the Rockies}

\section{DOGBANE FAMILY (Apocynaceae).}

A small family composed chiefly of poisonous tropical plants, usually with milky, acrid juices. They have perfect and regular, five-parted flowers and opposite, smooth-edged leaves.

INDIAN HEMP (Apocynum cannabinum) is a rather unattractive species with a smooth branching stem, rising from vertical roots to heights of 1 to 4 feet. The ovate-pointed leaves are lusterless, have very short stems and are closely crowded on the stalk oppositely to one another.

The small, five-parted, greenish-white flowers grow in terminal clusters. A tiny drop of nectar, secreted at the bottom of each small, shallow cup, furnishes food for quantities of insects, including a great many crawling ones that are of no value to the plant. The name of Indian Hemp has its origin because Indians formerly used the tough fibres as a substitute for hemp in their basket work. We find this species very abundant in dry fields and thickets throughout our range; it flowers from June to August.

SPREADING DOGBANE (Apocynum androsaemifolium) is a much more attractive species than its relative, just mentioned. It grows from 1 to 4 feet high, and has many long, spreading branches. The short-stemmed, broadly ovate-pointed, pale green leaves grow oppositely, to the ends of the branches, the leaves are all approximately in the same plane, that is, each succeeding pair does not appear at right angles to the pair before-it, as is usually the case. The clusters of flowers terminating the branches are composed of pink, bell-shaped blossoms, having five, pointed, recurved lobes; they are veined with deeper pink and are fragrant. It is adapted to, and largely dependent upon butterflies for the quickening of its seeds. Common on borders of fields or thickets within our range. 


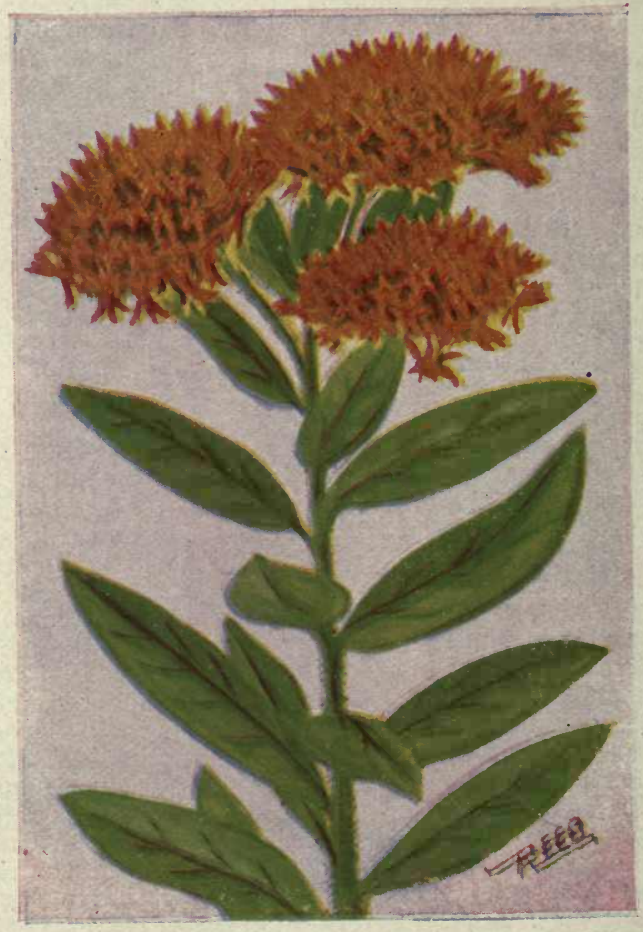

\section{Butterfly-Weed.}

Asclepias tuberosa. 


\section{MILKWEED FAMILY (Asclepiadaceae).}

A family of stout-stemmed plants having milky juices and ,usually, large opposite or whorled leaves. They all have umbels of small flowers that are very peculiar in construction and highly specialized for cross-fertilization by particular classes of insects. Each blossom has five tiny structures shaped like wish-bones, with pollen masses on each end. They are so placed that the visiting bee or butterfly is pretty sure of getting one or more of its legs caughtin the sharp angle at the apex and must, in order to get free, tear the tiny arrangement from its support. He then flies to the next plant with this dangling from his legs. It is an unique method of forcing insects to work for it, but one that never fails as far as the plant is concerned, but sometimes proves a fatal trap for insects lacking the strength to tear away the tiny pollen saddle bags. We often find the corpses of several such insects hanging from the flower cluster, with their legs hopelessly entangled.

\section{BUTTERFLY-WEED;}

PLEURISY-ROOT; ORANGE MILK-WEED (Asclepias tuberosa) is the most brilliantly colored species of the genus. Even those accustomed to the sight of this plant cannot suppress the feeling of admiration that stirs them as they suddenly behold the vivid, orange flashes greeting them as they cross waste or dry fields.

The stem of butterfly-weed is usually erect, from 1 to 3 feet high; it is rather rough and has but little of the milky juices so common to the other species. The leaves are pointed-oblong, very short-stemmed or seated oppositely. The beautiful orange flowers grow in flat-topped clusters or umbels, at the summit of the plant. It is found from Mass. to Minn. and southwards, most abundant in the Southern States. Its roots are used medicinally. 


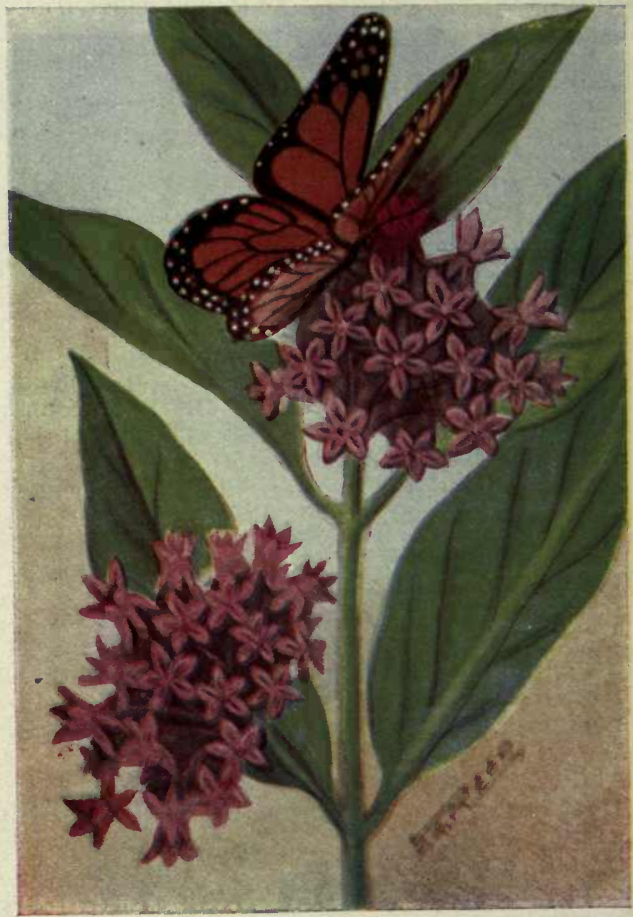

Common Milkweed.

Asclepias syriaca. 
COMMON MILK-WEED (Asclepias syriaca) is the most abundant and the best known of the Milkweeds. It grows everywhere along roadsides, in fields and on the borders of woods. The rather stout stem rises from 2 to 5 feet high and has numerous, opposite, large, oblong, short-stemmed leaves of a yellowgreen color. Both the leaves and the stem are finely hairy and both yield quantities of a thick, sticky, bitter, milky fluid if they are broken or bruised anywhere. It has been found that the outer covering of the stem is extremely delicate and that the tiny, claw-like feet of insects that attempt to crawl up the stalk will cut through this covering sufficiently to cause the feet of such visitors to become sticky with the milky fluid; this not only discourages the would-be pilferers of the flowers' sweets but makes it quite impossible for them to reach the top of the long stem. Ants frequently become so gummed up with the sticky substance that it causes their death.

The flowers grow in rounded clusters often in a pendent position, from the axils of the upper leaves. They are very fragrant and secrete an abundance of nectar. They are visited by many varieties of bees and butterflies, by one of the latter so frequently that it is known as the Milkweed Butterfly (Anosia plexippus.)

In the Fall, the clusters of lilac-colored flowers have been replaced by large, rough-coated seed-pods that are completely filled with the silkiest of flossy substance attached to the numerous black seeds; finally the pod bursts and liberates the seeds, each floating away on the breeze, sometimes aviating for several miles before coming to earth. This provision for the spreading of the seeds results in a widely distributed, strong race, that is ever on the increase. 


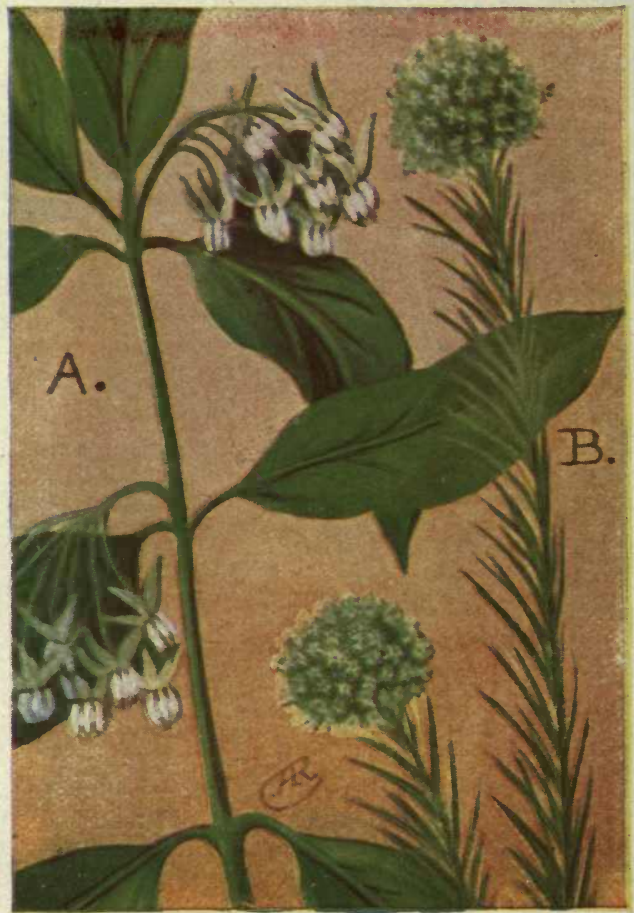

A. Poke Milkweed.

Asclepias syriaca.

B. Narrow-leaved Milkweed. Asclepias verticillata. 
POKE MILK-WEED (Asclepias phytolaccoides) is a tall species growing from 2 to 6 feet in height. The flowers composing its clusters are fewer in number than those of the common milkweed but much larger and of a clear, ivory-white color. The flower stems are long and slender so that the entire cluster is in a nodding position, it being the only one of the genus in which all the flowers are pendent. The leaves are large and thin, and pointed at each end. The seed-pod is large and has a longer, more pointed tip than that of the Common Milkweed. Poke Milkweed is found, usually in dry situations, along the edges of woods or along roadsides, from Me. to Minn. and southwards. It flowers from June until August.

WHORLED MILKWEED (Asclepias verticillata) is a very slender species, common in dry woods and on prairies in the South; found north to Mass. and Saskatchewan. The stem is slender, simple and rises from 1 to 3 feet high. The narrow linear leaves have their margins rolled under; they grow in closely clustered whorls about the stem, usually quite erect. The numerous, small, greenish-white flowers grow in a round clusters or umbels at the summit of the stem. It is a very dainty species, one not apt to be confused with any other member of the family. Both the stem and the leaves are slightly downy and have a whitish bloom. Their juices are milky like those of the others.

PURPLE MILKWEED (Asclepias purpurascens) is a common species whose umbels of deep magneta flowers loom up conspicuously in dry fields and thickets, from June until August. It is found from Me. to Minn. and southwards.

FOUR-LEAVED MILKWEED (A, quadrifolia) bears one or two whorls of four leaves about midway of the stem and several pairs near the summit. It is a delicate species with few clusters of small magenta flowers. 


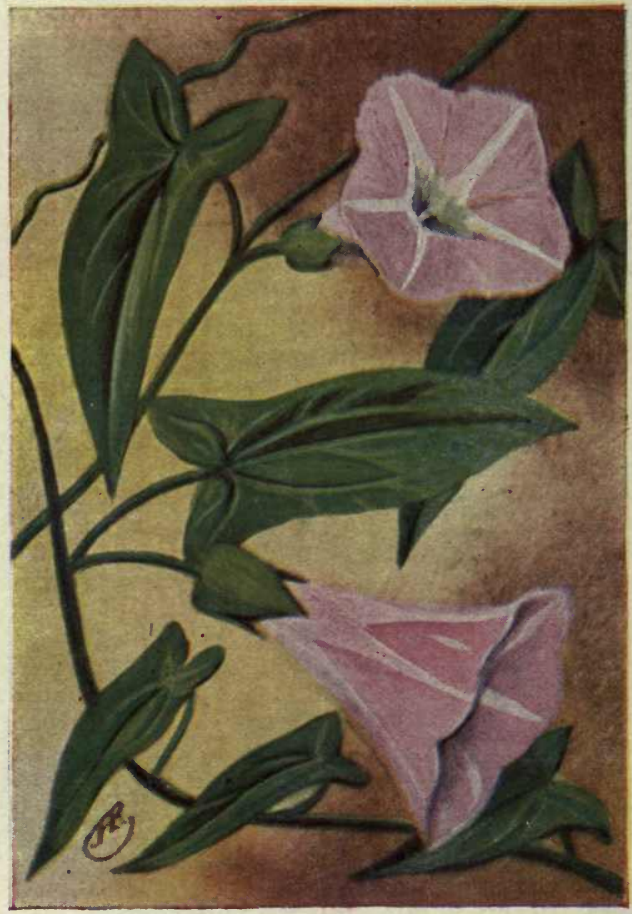

Hedge Bindweed; Morning Glory. Convolvulus sepium. 


\section{CONVOLVULUS FAMILY (Convolvulaceae).}

A small family of climbing or twining herbs having regular, perfect, usually bell or funnel-shaped flowers and alternating leaves.

HEDGE BINDWEED; WILD MORNING GLORY (Convolvulus sepium) climbs gracefully over walls, through thickets or twines its stem tightly about those of other plants or shrubs. Its embrace is sometimes so ardent that it causes suffocation and death to the plant to which it attaches itself. The stem is smooth, rarely slightly hairy, and grows to lengths of from 3 to 10 feet.

The leaves are triangular or slightly arrow-shaped on long petioles. The large funnel-shaped blossoms grow singly on slender peduncles from the axils of the leaves. They are pink with white stripes and a flaring mouth; the calyx consists of five sepals that are concealed by two large bracts at the base. The flowers remair open only during sunshine and occassionally on bright moonlight nights. At the base of the corolla are five tubes leading to the supply of nectar. Only long tongued bees, butterflies or moths are able to reach the sweets, to which they are guided by the white stripes on the inside of the tube. It is very commonly found in moist ground along roadsides or the borders of woods or thickets, throughout our range and also in Europe.

COMMON DODDER (Cuscuta Gronovii) is a very common little parasitic plant found in moist shady thickets or among the shrubs and plants bordering ponds or streams. It germinates its seeds in the ground and the slender stem rises until it comes in contact with some living plant, when the root dies and the dodder gets its nourishment from its host by means of numerous little suckers. It has no leaves; the stem is orange and the clusters of minute bell-shaped flowers are white. 


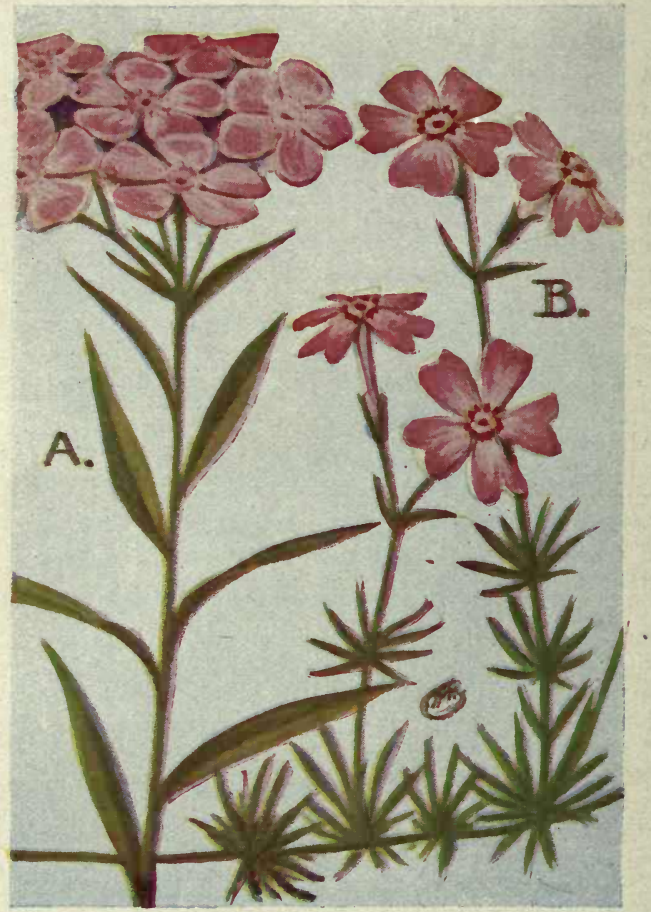

A. Downy Phlox.

Phlox pilosa.

B. Moss Pink.

Phlox subulata. 


\section{POLEMONIUM FAMILY (Polemoniaceae).}

A small family of herbs having either opposite or aiternate leaves and regular, perfect flowers, the lobes of the corolla being convolute in the bud.

DOWNY PHLOX (Phlox pilosa). Both the leaves and stem of this species are covered with fine, downy hairs; the sharply pointed calyx is also hairy and sticky. The plant stands from one to two feet in height. The narrow, lance-shaped leaves are rather closely alternated along the stem. The flowers are in a flat-topped clusters at the summit. The five lobes of the corolla are wide spread and bluntly pointed. The flowers vary in color from a magenta-pink to white.

All varieties of phlox are hardy and make excellent garden plants, a purpose for which they are extensively used. The present species ranges from Conn. to Manitoba and southwards, flowering during May and June in dry woods or on prairies.

BLUE PHLOX (Phlox divaricata) also has a slightly downy, hairy stem, with broader leaves and leafy, decumbent shoots from the base. The flowers are in loose flat-topped clusters. The five lobes of the corolla are pale lilac and usually notched at the ends. It is found in damp, rocky woods from N. Y. to Minn. and southwards.

MOSS PINK; GROUND PINK (Phlox subulata) is a low, creeping species that spreads over sandy or rocky ground, forming compact masses resembling moss. The stem is very branchy but grows only a few inches high; the ends of the branches turn upwards and terminate in clusters of flowers varying from crimson pink to white. The five, spreading lobes of the tubular corolla are wedge-shaped and notched at the tips. The stiff, pointed, evergreen leaves are closely crowded along the stem. Ground Pink is found from western N. E. to Mich. and southwards. 


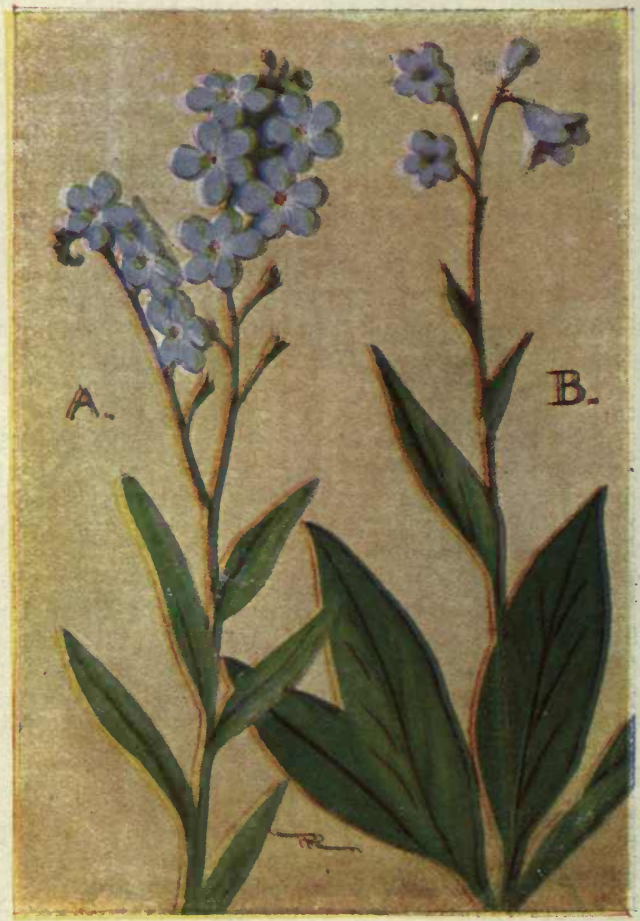

A. Forget-me-not.

-Myosotis scorpioides. B. Wild Comfrey. Cynoglossum virginianum. 


\section{Wild Flowers East of the Rockies \\ BORAGE FAMILY (Boraginaceae).}

A family of herbs with rough stems and leaves and perfect flowers, regular except in the case of Echium.

FORGET-ME-NOT (Myosotis scorpioides) (EUROPEAN) Doubtless this pretty little plant is familiar by name, at least, to all my readers. Besides its own peculiar charms it has a great many legendary and poetical associations connected with it. It has also been a favorite flower for painters the world over.

Forget-me-not is a common wild flower in Europe and Asia, but is not indigenous in this country. It does, however, appear as an escape and is fairly well established in Nova Scotia, New England, New York and southwards. The stem is rather stout but weak, it rise about a foot in height, and is smooth but the leaves are rough and hairy. The flowers are borne in one-sided curving terminal clusters. The five, broad, rounded petals are sky-blue with a yellow eye; the undeveloped buds are pink. The generic name was given because one of the species has soft leaves shaped like mouse ears. The specific name refers to the curved tendency of the flower stalk containing the buds, it being curved after the fashion of a scorpion's tail. There are several species of Myosotis, the present one having the largest and most beautiful flowers.

WILD COMFREY (Cynoglossum virginianum) is a common, rough-stemmed perennial growing in deciduous woods from Me. to Mich. and southwards. The tubular corolla is pale blue; it is set in a five-parted hairy calyx. The basal leaves are large and ovate; the stem ones clasp the flower stalk with somewhat heart-shaped bases. The fruit succeeding the flowers, is composed of four very bristly nutlets. 


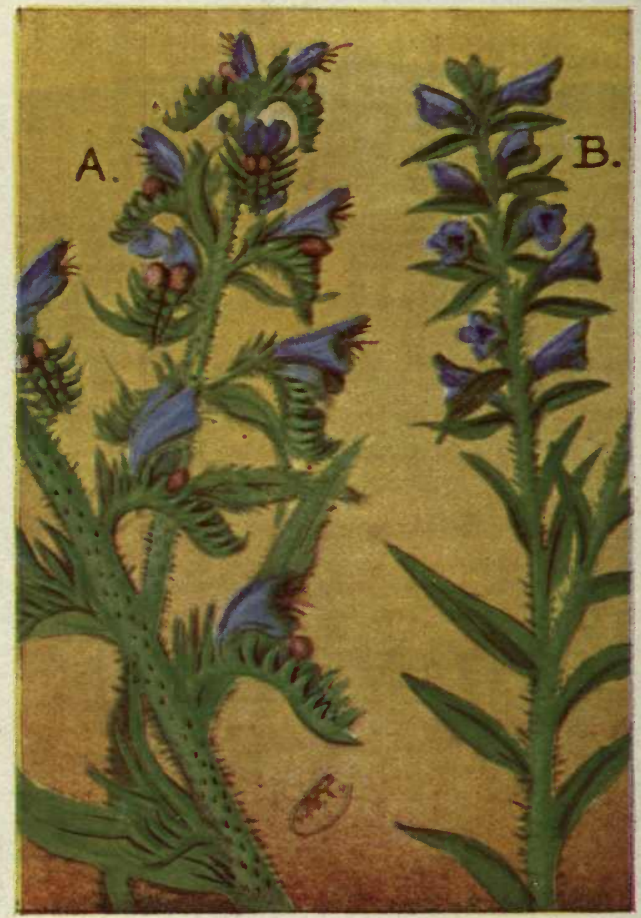

A. Blue-weed; Viper's Bugloss.

Echium vulgare. B. Small Bugloss. Lycopsis arvensis. 
BLUE-WEED; VIPER'S BUGLOSS (Echium vulgare) (EUROPEAN). This peculiar plant is locally abundant in dry fields and waste places in the East. It is a waif that has strayed across the ocean, and, I must confess, it is one that farmers wish had stayed in its native countries. It is often regarded as a pest and is a difficult one to get rid of. Of course the botanist welcomes it, as he does any new species that he comes upon; it has unusual flowers both as to form and to manner of growth. We can safely say that Blue-Weed will never be popular as a flower for bouquets; one has but to touch it to find the reason, the stem is thickly set with light-colored bristles as sharp as needle points and even more penetrating.

The stem is light green, spotted with purple; it grows erect from 1 to 3 feet high. The alternating leaves are rough, hairy and clasping. The flowers grow on leafy spike, springing from the stem near the top. When the first flowers appear, in June, they are close to the stalk at the base of the rolled-up, leafy spike. As they continue to bloom, the spike gradually straightens and the open flowers appear farther and farther from the stem, leaving behind them a train of wrinkled nutlets in the axils of the small leaves. The showy, tubular corolla is bright blue, and is exceeded in length by the long stamens and three-parted style; the buds are pink.

SMALL BUGLOSS (Lycopsis arvensis) (EUROPEAN). This is a very rough, bristly-stemmed species, also naturalized from Europe, and now found in waste places near dwellings, from Me. to Minn. and south to Va. The lanceolate leaves are seated on the stem; they diminish to the size of bracts and pass into the racemes of small, tubular violet-blue flowers that terminate the branching stem. The curved corolla is but little longer than its enclosing, hairy calyx. 


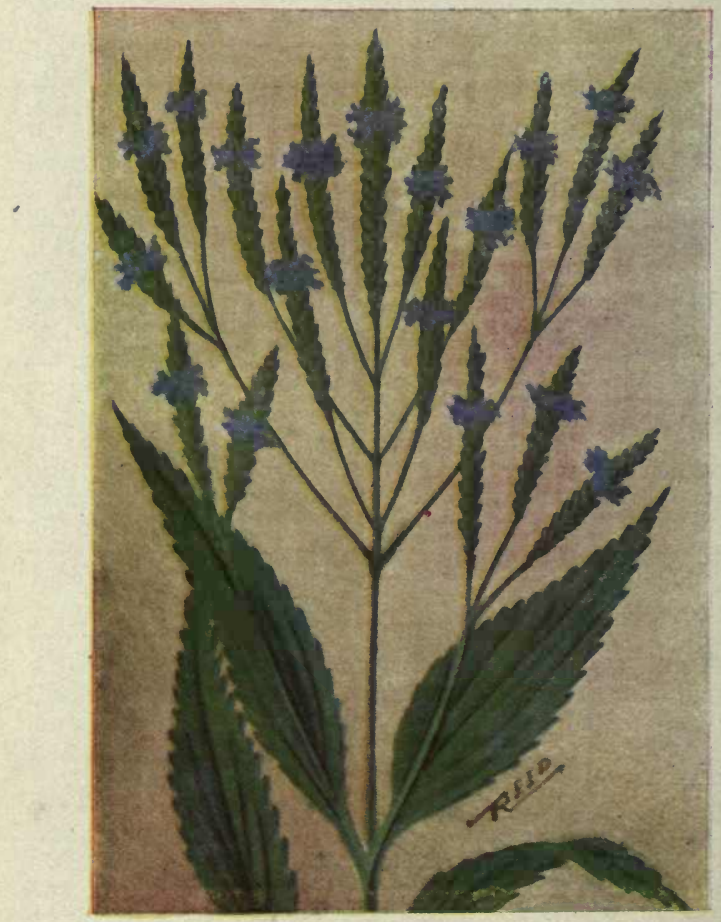

Blue Vervain.

Verbena hastata. 


\section{Wild Flowers East of the Rockies}

\section{VERVAIN FAMILY (Verbenaceae-}

Herbs with opposite leaves and perfect but usually irregular flowers, the tubular corollas spreading into two lips or four or five lobes.

BLUE VERVAIN (Verbena hastata) is our most common example of the genus. It is a tall, slender, rank-growing plant reaching heights of 2 to 7 feet. The leaves are dark green, short-stemmed, lanceolate, sharply toothed and grow oppositely on the stem.

At the top of the stem are numerous, slender flower spikes, each branching from the stem and assuming a vertical position, in a regular order suggestive of candelabra. These slender spikes contain many buds, the lower of which open first. From July until the end of August we will find rings of purple flowers about the spikes, gradually drawing nearer the ends as the flowering season advances, and leaving behind a long trail of purplish calyces. The tubular corolla has five spreading lobes, a slender pistil and two pairs of stamens. Blue Vervain, which is found throughout our range, was formerly, and is now to some extent, used for certain home medicinal remedies.

WHITE VERVAIN (Verbena urticaefolia) is a similar but smaller and even more slender species found in thickets and waste ground. The flower spikes are very slender and the flowers much smaller than those of the last species, and they are white in color. The stem grows from 2 to 4 feet high, is erect, coarse, four-sided and grooved.

Verbena canadensis is quite different; it has an erect bristly-hairy stem from 6 to 18 inches tall and opposite, deeply lobed and toothed leaves. The lilac flowers, nearly an inch broad, are in short terminal clusters; the tubular corolla has five spreading, notched lobes. It grows in open woods and on prairies from Ind. to Dakota and southwards. 


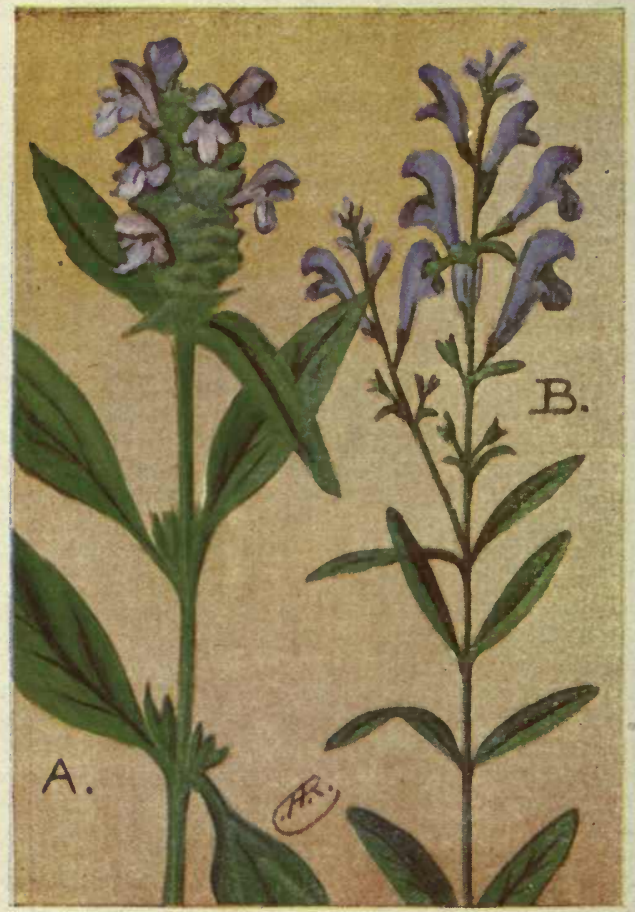

A. Self-heal.

Prunella vulgaris.

B. Skullcap.

Scutellaria intergrifolia. 


\section{Wild Flowers East of the Rockies}

\section{MINT FAMILY (Labiatae).}

A very large family of herbs having, usually, square stems, strong scented foliage and small tubular flowers conspicuously situated in spikes or from the leaf axils. The flowers usually have two-lobed or entire upper lips and three-lobed lower. They all bear honey and are nearly all dependent upon members of the bee family for cross-fertilization.

SELF-HEAL; HEAL-ALL (Prunella vulgaris) is one of the commonest and most widely distributed members of the mint family. Along roadsides, in fields and on the borders of woods, everywhere throughout the country, we will find this familiar flower. The stem grows from 6 to 15 inches high and is topped with a cylindrical flower head, composed of many, two-lipped, tubular, purple florets. But few of these bloom at a time commencing at the bottom, and the flowering season extends from June to September. The leaves are sparingly toothed and seated oppositely on long stems. Usually several leaflets appear from their axils and sometimes smaller flower heads from the axils of the upper ones. It is frequented most often by bees, in fact it is often known as the "bee flower."

SKULLCAP (Scutellaria intergrifolia) is one of the handsomest of the Skullcaps, the tubular, two-lipped flowers in the loose terminal spike, each measuring about one inch in length. The downy stem rises from 6 to 24 inches high and is set oppositely with toothless, lance-shaped, round-ended leaves. It is found in dry ground from Mass. to Fla. and along the Gulf.

BUGLEWEED (Lycopus virginicus) is similar in general form to the last; the-leaves are coarsely toothed. The tiny, white, tubular flowers are in small clusters in the axils of the leaves. A slight, fancied, bugle-shape to the corolla form the basis for its common name. 


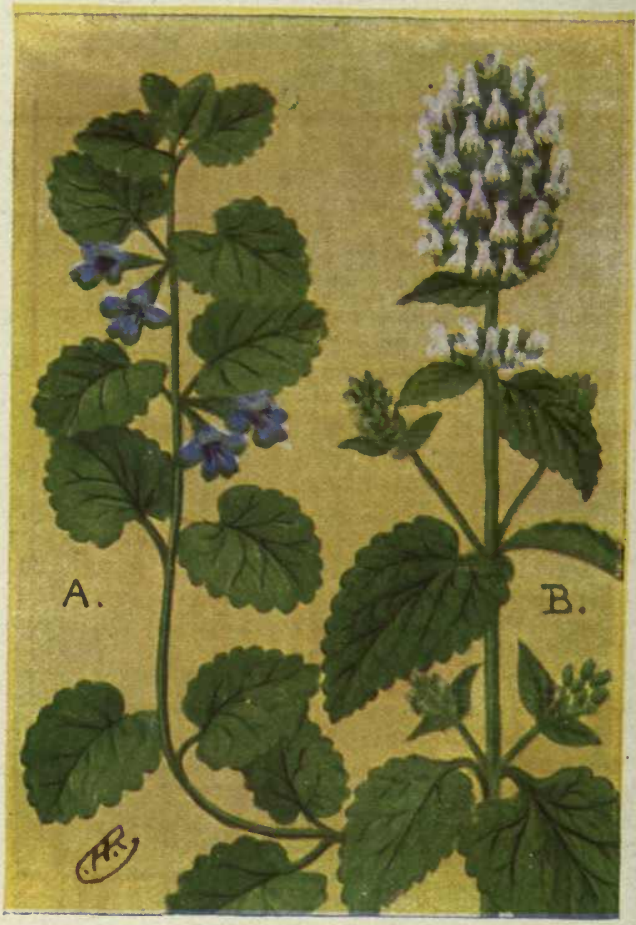

A. Ground Ivy; Gill-over-the-Ground. Nepeta hederacea.

B. Catnip.

Nepeta Cataria. 
GROUND IVY; GILL-OVER-THE-GROUND (Nepeta hederacea) (EUROPEAN) is a beautiful little trailing mint that grows very profusely about country houses, where it has escaped at some time from cultivation. It is very inconspicuous and lowly in its habits, so that it is very apt to escape notice even when it is in flower. Its stems are weak and procumbent; it frequently strikes root from the stem at the angles of the leaves so that it may trail over the ground for a long distance from the parent root. The upright flowering stems, given off from this creeping one, rarely exceed eight inches in height.

The leaves rise from the stem in pairs; they are round, with a heart-shaped bases, the edge cut into rounded lobes, and their whole surface is downy and veiny. The pretty little purple flowers grow in small clusters from the axils of the leaves. The upper lip is erect and slightly notched; the lower one has three spreading lobes and is spotted with dark purple.

Depending upon the amount of light and moisture received, the stems and leaves vary greatly in color from green to a purplish-red. Ground ivy is found in blossom from May to July throughout the eastern half of our country.

CATNIP (Nepeta Cataria) (EUROPEAN) is a very common mint, introduced from Europe, the aromatic foliage of which has a very peculiar attraction for all members of the feline race. It apparently has an intoxicating effect upon them; after eating the leaves they will roll about on them for a long time. . It also formerly was used for making Catnip tea, a one-time remedy for most of the ills of childhood. The plant has a stout, square hollow stem from 2 to 3 feet tall and is downy, as are the sage green, toothed leaves. The lilac-white flowers are clustered on peduncles from the axils of the leaves. Catnip is common throughout our range. 


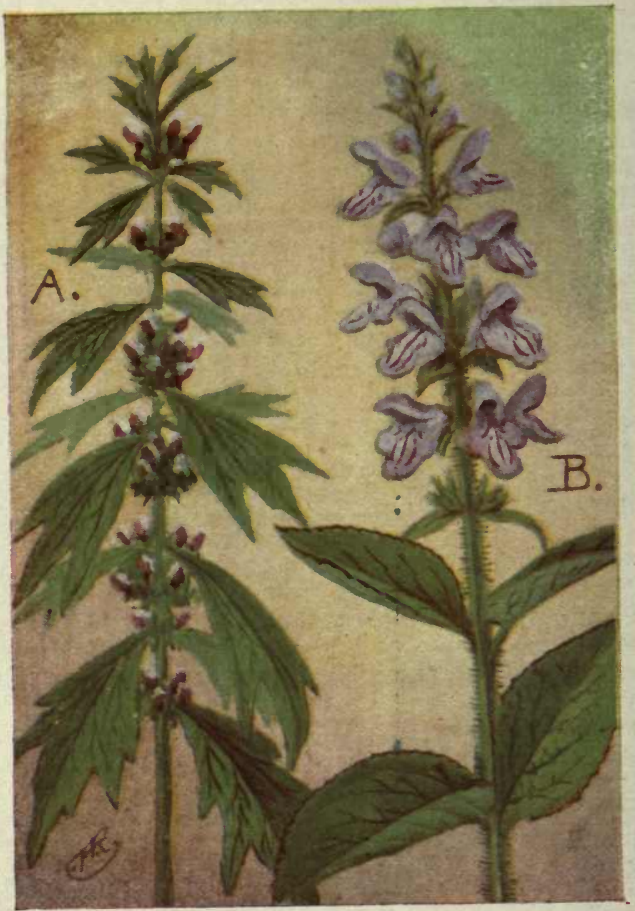

A. Motherwort.

Leonurus cardiaca.

B. Hedge Nettle.

Stachys palustris. 
MOTHERWORT (Leonurus Cardiaca) (EURO. PEAN) is a simple, erect-stemmed mint growing from 2 to 4 feet high. It has a very decorative effect, the leaves being large at the base of the stem and rapidly diminishing as they approach the top; the lower ones are quite long-stemmed and all are palmately slashed. The flowers grow in round clusters surounding the stem at the axils of the leaves.

The numerous flowers composing these clusters have tiny, two-lipped, white, pink or purple corollas and minute stamens. Both the stem and the leaves have a woolly texture and the former are strongly veined. Motherwort is commonly found about old country dwellings and along roadsides. We find it in bloom from June until August. It is a much more leafy species than most of the mints; the pairs of leaves are closely crowded together and extend in all directions from the stem.

WILD MINT (Mentha arvensis canadensis), a common species, is one of our few native mints. It has a simple stem from 1 to 2 feet high and toothed, petioled lance-shaped leaves. The tiny white or lilac-white flowers are clustered around the stem in the axils of the opposite leaves. Both the stem and the leaves are more or less hairy and have an aromatic odor resembling pennyroyal. Wild Mint is common throughout the United States and southern Canada.

HEDGE NETTLE; WOUND-WORT (Stachys palustris) is a tall mint ( 1 to 3 feet) with a downy-bristly stem and purple, tubular, two-lipped flowers in a terminal spike and from the axils of the upper leaves; lower lip streaked and spotted. Common in moist ground from N. S. to Manitoba and southwards.

PEPPERMINT (Mentha piperita) (EUROPEAN) has ovate-pointed, finely toothed leaves, usually with pairs of leaflets from the axils and little purplish flowers in small terminal spikes. 


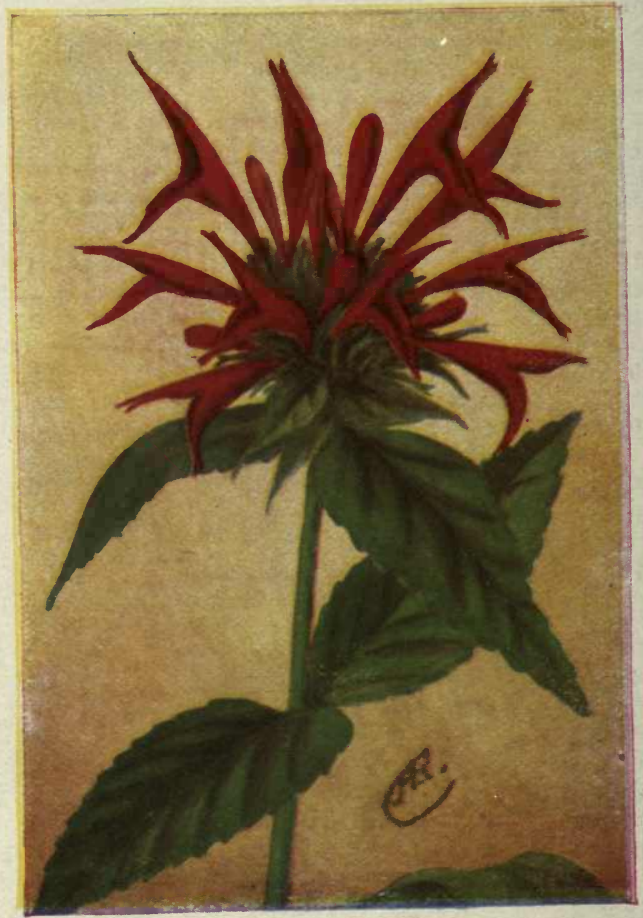

Oswego Tea; Bee Balm.

Monarda didyma. 
OSWEGO TEA; BEE BALM (Monarda didyma) is one of our most brilliantly colored wild flowers and shares with the Cardinal Flower the honor of being the most intensely scarlet colored. It grows along the shady borders of woodland streams or pools where its vivid coloring is in strong contrast with the deep greens of the surrounding vegetation. The stem is hairy and rather rough; it attains heights of two feet or more. The short-stemmed, broad-lanceshaped leaves are light green, sharply toothed and rather thin. the stem and the smaller leaves, just below the flower heads, are often tinged with ruddy.

The flowers grow in rounded terminal heads, composed of numerous, long tubular, scarlet florets. The upper lip is long, arched, pointed and often notched at the tip; the lower lip is three-parted, the middle one being longer than the side ones.

Nectar, seated at the base of the long tube, can only be reached by long-tongued insects. Best adapted to it are bumble bees and certain of the butterflies. The Ruby-throated Hummingbird, too, attracted to this, his favorite color, often partakes of the sweets. Two Stamens with prominent anthers and a pistil with a two-parted stigma, are so situated in the throat of the flower that it is impossible for either bee or butterfly to reach the honey-cup without pollenizing the stigma, usually with some brought from another blossom. From July until September this beautiful species blooms in suitable localities from Quebec to Manitoba and southwards to Ga. and Mo.

WILD BERGAMOT (Monarda fistulosa) is a quite similar species with a smooth stem and paler flowers, either pink or magenta-pink in color. The upper leaves are stained with the shade of purpie or lilac that characterizes the flower bracts. We find this species in dry ground in the same range. 


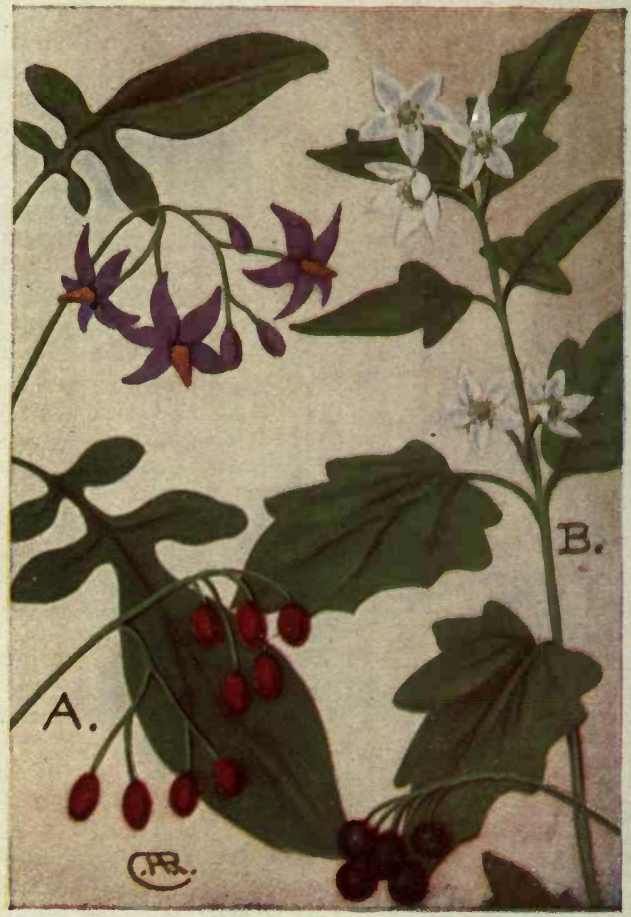

A. Bittersweet.

Solanum Dulcamara.

B. Black Henbane.

Hyoscyamus niger. 


\section{NIGHTSHADE FAMILY (Solanaceae).}

A small family of herbs, some of them very valuable, having colorless juices, alternating leaves and regular five-parted flowers, usually with five stamens and a short pistil.

BITTERSWEET; NIGHTSHADE (Solanum Dulcamara) (EUROPEAN); although an immigrant, is quite common in the eastern half of our country. It chooses for its habitat, moist thickets or the edges of ponds where there are plenty of shrubs to help support it, for this species has weak stems with climbing tendencies.

It is a species that often attracts the attention of the casual passerby because of the beauty and quaint forms of its flowers and leaves. It grows from 2 to 8 feet tall and throws out numerous, long branches that climb and sprawl over the surrounding vegetation. The dark green leaves are variable in form; some are lobed, others have small lateral leaflets and still others have another pair of still smaller leaflets on the leaf stem. The flowers hang in loose clusters on long peduncles from the axils of the leaves; they have five, reflexed, purple petals and a yellow, conical center formed by the stamens. The berries that succeed the flowers are first green, then turn yellow and ultimately a deep ruby-red. This species blooms from June until.September and, like most plants with a long period of bloom, we may often find flowers and berries in all stages of color at the same time.

BLACK NIGHTSHADE (Solanum nigrum) is a native species with a smooth, erect, branching stem 1 to 2 feet high. The long-stemmed ovate leaves have a wavy-lobed edge. The five-parted white flowers grow in few-flowered clusters from the leaf axils. the round berries are black when fully ripe, and are quite poisonous. This species is found throughout our range, frequenting waste ground. 


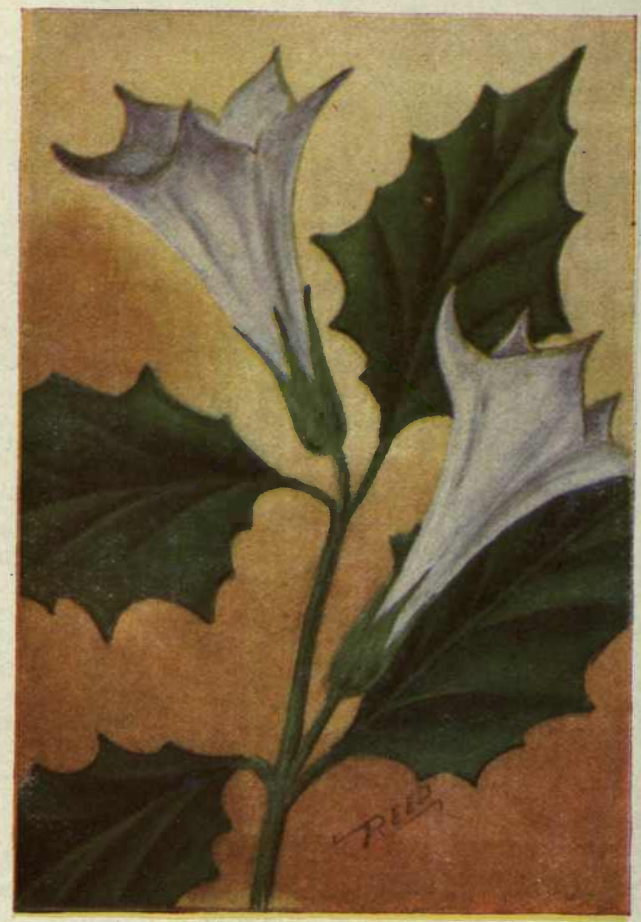

Purple Thorn Apple.

Datura tatula. 
PURPLE THORN APPLE (Datura Tatula) is a large, ill-scented, rank-growing weed with a stout, smooth stem from 1 to 5 feet high. The long-stemmed leaves have very irregular, coarsely toothed outlines. The lavender-colored, trumpet-shaped flowers are about four inches long. The flaring corolla has five broad sharply pointed lobes and is seated in a light green, five-parted calyx about half its length. Usually the color of the corolla is more intense on the lobes and often shades to white towards the base of the tube. After flowering, a large green, fruit-capsule about two inches long appears; it is ovoid in shape and armed with stout prickles. The entire plant has poisonous juices, because of which and the unpleasant odor, farmers usually try to suppress it on their premises. It grows in waste ground, especially about barnyards, from Me. to Minn. and southwards.

THORN APPLE; JIMSON WEED (Datura Stramonium) also comes from across the water; it is very similar to the preceding, grows in the same places and in the same range. The flowers are white and the leaves are lighter green; the stem is also somewhat stouter.

All the preceding members of the Nightshade Family have more or less poisonous qualities, but there are others that are of inestimable value to mankind. The Potato, one of the most valuable and widely cultivated vegetables throughout the civilized world, belongs to the genus Solanum. It is specifically termed Solanum tuberosum. The common Tomato belongs to another genus of this same family (Lycopersicon). The Egg Plant is Solanum Melongena. Not only do these valuable food products come from members of this family, but one of the oldest and most widely cultivated of our garden flowers does too,- - the Petunia. 


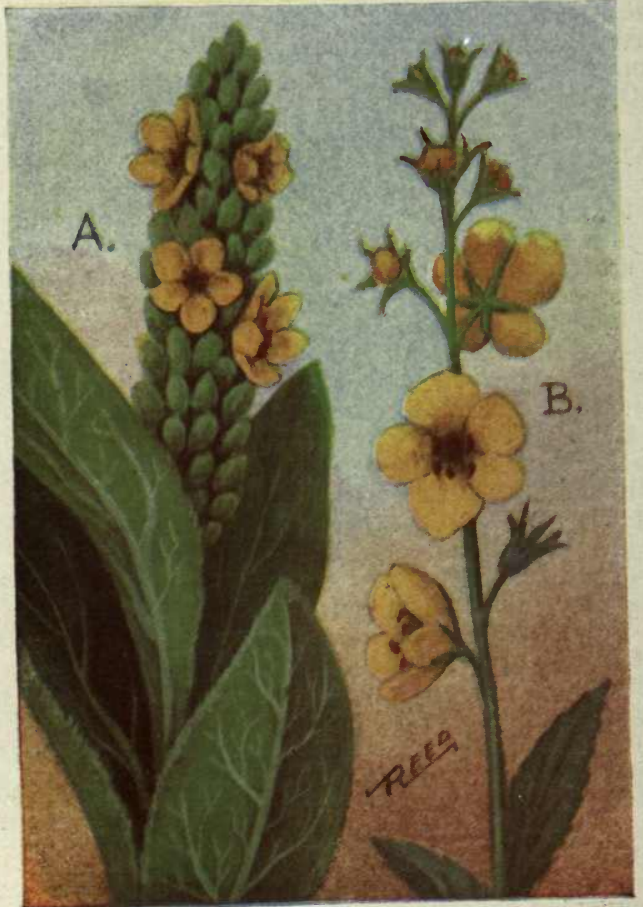

A. Common Mullein; Flannel Plant. Verbascum Thapsus. B. Moth Mullein. Verbascum Blattaria. 


\section{Wild Flowers East of the Rockies}

303

\section{FIGWORT FAMILY (Scrophulariaceae).}

A large family of herbs with perfect but irregular flowers, usually with two sets of stamens of different lengths. They all have bitter juices and some of them are narcotic-poisonous.

COMMON or GREAT MULLEIN (Verbascum Thapsus) (EUROPEAN). This well known plant is one of the most common sights along roadsides and in dry fields. It is very conspicuous, the more so from the fact that it commonly grows where other plant life is of small stature. Its long stalk rises from 2 to 7 feet above ground; the plant may well be compared to its neighbors as a modern skyscraper surrounded by cottages.

Mullein leaves are very soft, with fine white downy hairs; they have given to the plant a name very often applied,-"Flannel Plant." The basal tuft of leaves first appears; they are large, ovate and pointed. The ones on the tall stalk are smaller and diminish in size to bracts as they reach the bottom of the long flower spike. From June until September, these flowers open a few at a time and last but a day. The light yellow corolla has five uneven, concaved lobes and five protruding stamens; three of the stamens are fuzzy and tipped with orange anthers, the others are smooth.

Mullein is always associated in my mind with Kingbirds because the tall spires are commonly used as lookout perches. It is very common throughout our range.

MOTH MULLEIN (Verbascum Blattaria) (EUROPEAN) has a tall, very slender stalk at the summit of which is a loose raceme. The flowers open two or three at a time; they are large, have five petals, very prominent stamens and orange anthers. The upper leaves are lance-shaped, the lower ones have the margins deeply cut, toothed, and notched. It is common from Me. to Ontario and southwards. 


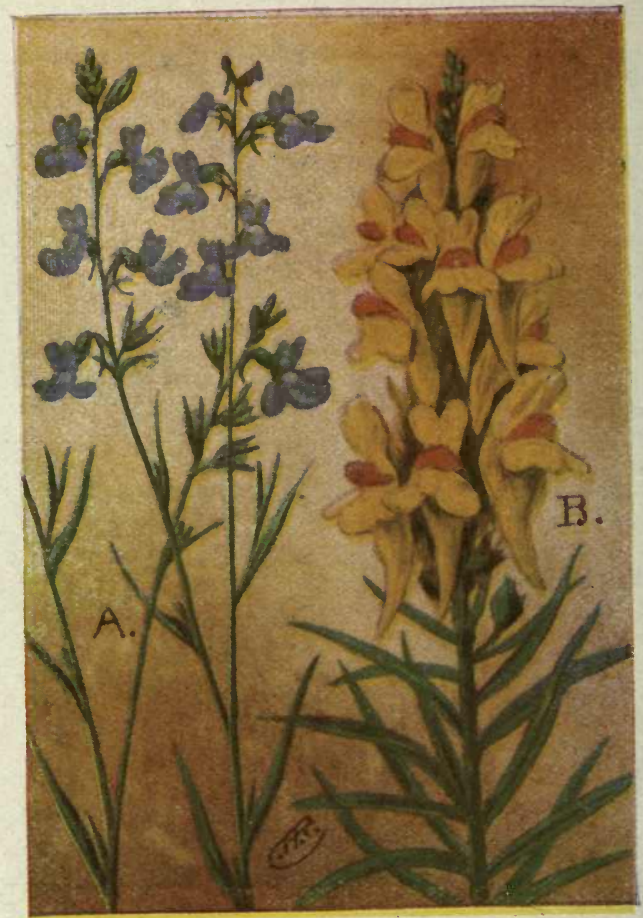

A. Blue Toadflax.

Linaria canadensis.

B. Toadflax; Butter-And-Eggs.

Linaria vulgaris. 
BLUE TOADFLAX (Linaria canadensis). This is a very slender and dainty species related to the very common introduced "Butter-and-Eggs. The stem attains heights of from 5 to 30 inches, but is so slender and weak that it is often supported by the surrounding plants. The small linear leaves alternate along the stem and continue in a diminishing size to the ends of the branches, where they act as bracts for the loose raceme of flowers.

The little tubular flowers are violet-blue in color; the corolla is two-lipped, the upper one having two lobes and the lower one three; the latter is pouchshaped and extends backwards into a very slender spur. Blue Toadflax is commonly found in dry sandy fields throughout the United States and southern Canada.

TOAD-FLAX; BUTTER-AND-EGGS (Linaria vulgaris), although an immigrant, takes so kindly to our land that it has extended its range from the Atlantic to the Pacific and southern. Canada to the Gulf of Mexico. It is a very attractive plant and interesting in many ways. The stem is simple and from 6 to 30 inches high. The narrow alternating leaves are grayish green, covered with a whitish bloom. As the plants grow often in dense colonies the effect on the landscape is that of a grayish bank, studded with gold and orange jewels.

The tubular, yellow flower has a two-lipped corolla, the upper one being of two lobes and the lower one three, the center one of which extends into a large sac-like spur and has a protruding, pouting, orange palate that closes the throat of the blossom. This arrangement is designed for the bumblebee, whose weight on the lower lip opens the flower so he can get at the nectar, while it is tightly closed to pilfering ants. We find Butter-and-Eggs in bloom during July to October in waste land, along roads and in fields or pastures. 


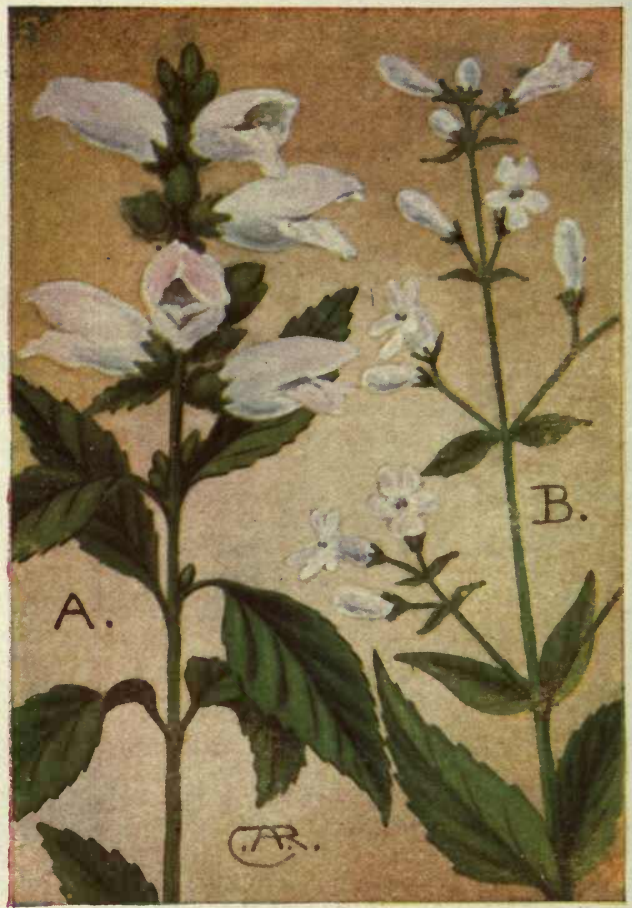

A. Turtle-head.

Chelone glabra.

B. Beard-tongued.

Pentesmon hirsutus. 


\section{TURTLE-HEAD (Chelone glabra.)}

Many plants derive their names from the fancied resemblance of their flowers to some well known objects. Often these fancies, are so far fetched that no one but the authors are able to discover the reason for the name. In this instance the profile view of the blossom really does give a suggestion of the head of a turtle; its generic name, too, is derived from the Greek, meaning a tortoise. Other names applied less often to this species are "Snake-head," "Cod-head" and "Shell Flower." It is a moisture loving plant and is usually found in wet locations in swamps or on the banks of streams or ponds.

The stem is stout, smooth and erect, from 1 to 3 feet tall. The leaves grow oppositely and are lanceshaped, stemmed, pointed and toothed. The flowers are clustered in a short spike at the summit of the stem; the corolla is tubular, about an inch in length and is white, tinged with pink. The upper lip is broad, arched, creased and notched in the middle; the lower lip is three lobed and woolly-bearded in the throat; the corollas are set in five-parted calyces which, in turn, are subtended by leafy bracts. Turtlehead blooms from July until September and ranges from Newfoundland to Manitoba and southwards.

PENTESMON; BEARD-TONGUE (Pentesmon hirsutus) has a straight, slender woolly stem that grows from 1 to 3 feet high. The leaves are light green, lance-shaped, rough-edged or minutely toothed, the upper ones seated oppositely on the stem and the lower ones with short petioles. The small magentawhite flowers are in panicled racemes. The trumpetshaped corolla has two lobes to the upper lip and three on the lower, the throat nearly closed by a hairy palate on the lower lip. Me. to Wisconsin and southwards. 


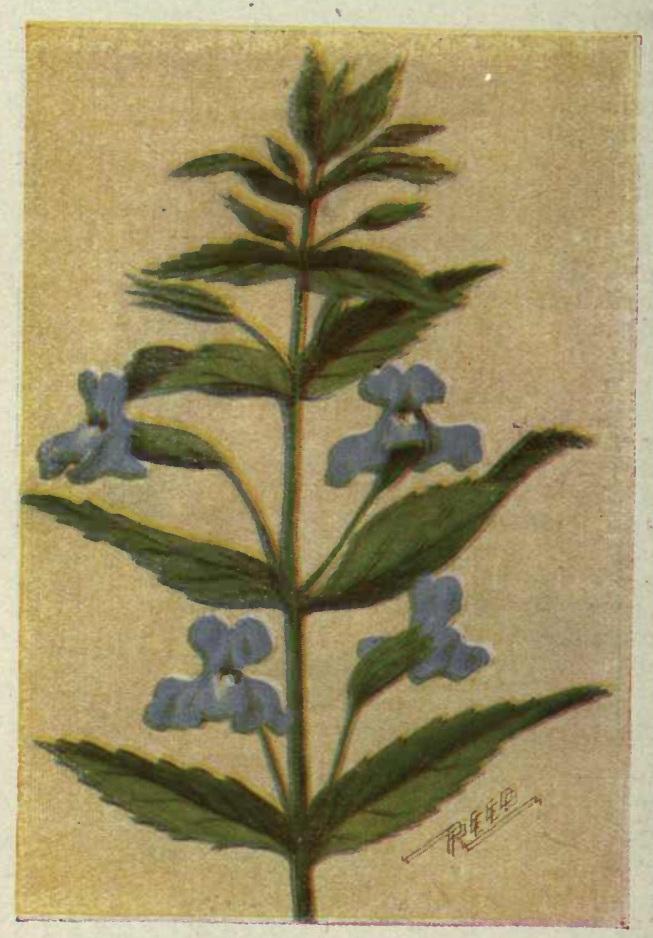

Monkey Flower.

Mimulus ringens. 
MONKEY FLOWER (Mimulus ringens) is a very appropriate name for this strange looking flower. Viewed from in front, the plaits and twists of the corolla are such that one can easily imagine that a little blue ape is grinning at him from among the leaves. The plant is a perennial with a smooth, square, hollow stem growing from one to three feet in height and branching considerably. The leaves, seated oppositely on the stem, are lance-shaped, pointed and slightly toothed. The flowers are few in number and are on long, slender pedicels from the axils of the upper leaves. They open one or two at a time. The pale purple flowers have two large lips, the upper divided into two lobes and the lower one into three, all broad and wavy. Four white stamens and a pistil nearly fill the throat, at the mouth of which are two bright orange-yellow spots.

A small store of nectar is secreted in the base of the flower tube. The double, yellow palate serves to close the entrance to the tube so that small useless insects may not be allowed to partake of the sweets within. When, however, the burly bumblebee alights upon the lower lip, his weight causes it to droop and allow easy access to its meager supply of nectar. $\mathrm{He}$ does not get it, though, without paying the price the flower asks, - that he bear away some of its precious pollen on his head and shoulders, to deposit at the entrance of the next blossom visited. Butterflies also sometimes visit the flowers, but without any resulting benefit to the latter, for their long, slender tongues readily pass down the throat of the flower and drain the honey-cup without their faces coming in contact with the anthers. Each flower is more or less adapted to certain classes of insects and endeavors, but not always with success, to erect barriers to keep away cther kinds. Monkey flower is found in wet places from N. B. to Manitoba and southwards. 


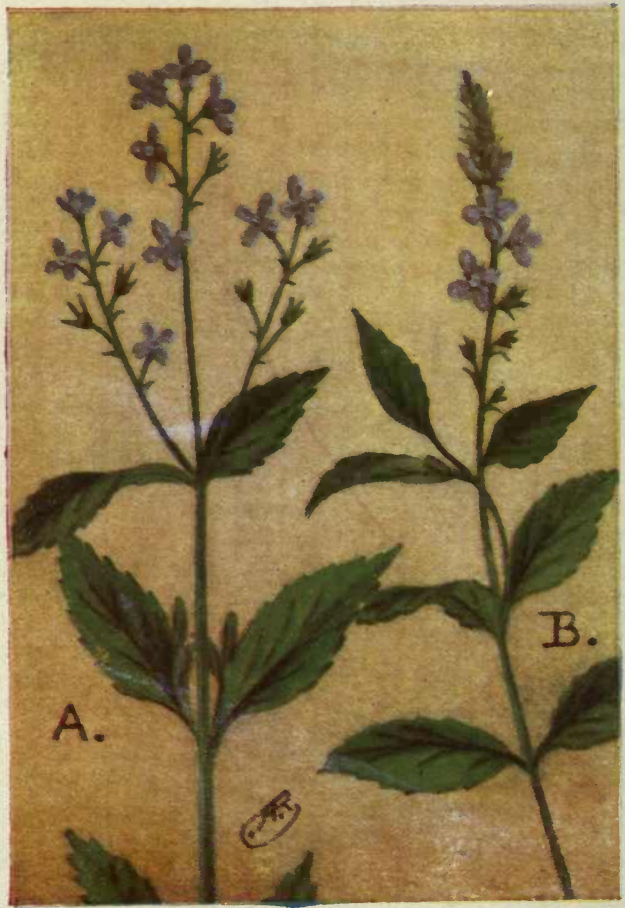

A. Am. Brooklime.

Veronica americana.

B. Common Speedwell.

Veronica officinalis. 
AMERICAN BROOKLIME (Veronica americana), the prettiest of the speedwells or veronicas, is a very frail plant; the stem is fragile and the petals fall off at the slightest provocation. At a short distance the little beds of blue flowers, lining the sides of the brook, might be mistaken for Forget-me-nots, but inspection quickly reveals the differences. Except when it does grow in colonies or beds, it is quite apt to be overlooked entirely for it is quite inconspicuous in the rank and luxurant vegetation that fringes the streams it inhabits.

The stem is stout, smooth, hollow and quite weak; the lower part spreads over the ground and frequently takes root at the angles of the lower leaves. At intervals, branches rise to height of 6 to 15 inches, bearing from the axils of the upper leaves, small fourparted blue flowers in loose racemes. The light blue petals have purple stripes and a white spot at the base: The two spreading stamens and the pistil are purple. The light green, oblong-lanceolate leaves are toothed and have short, flat stems.

Brooklime has a long season of bloom, being found in flower from May until September. It is common in moist ditches and along brooks or in swamps, from Newfoundland to Alaska and south to Va. and Mo.

COMMON SPEEDWELL (Veronica officinalis) is a popular little plant as common in dryfields and open woods as its preceding relative is in moist places. The prostrate woolly stem is erect at the end and terminates in a raceme of pale lavender, four petalled flowers, the lower petal of which is conspicuously smaller than the other three, a common trait of this genus. Speedwell is quite common through the United States and southern Canada. These two veronicas are the prettiest and the most common of several found in our range. 


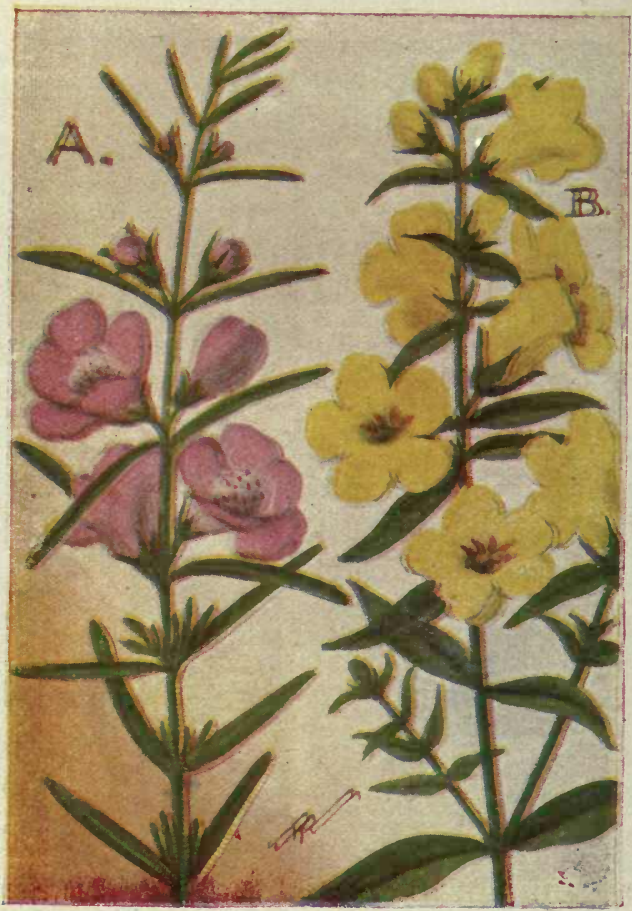

A. Purple Gerardia.

Gerardia purpurea.

B. Smooth False Foxglove.

Gerardia virginica. 
PURPLE GERARDIA (Gerardia purpurea) is a pretty little species that decorates low, moist, sandy fields and meadows with its beautiful purple-pink blossoms. The slender stem is quite branchy and averages about a foot in height, though it occasionally attains heights of two feet. The leaves, closely crowded along the stem, are linear, pointed and rough-margined. From three to eight flowers, opening one at a time, grow along the ends of each branch. The corolla is broad and about 1 in. long, bright purplish pink, the mouth of the funnel spreading into five rounded lobes, spotted or downy within.

If we watch these flowers for a few moments, we will be sure to see a big, burly, bumblebee buzzing along inspecting each blossom, not with an eye to their beauty but thinking only of the sweets they contain for him. As he reaches the bottom of the corolla, the flower fits over his head like a little toboggan cap. All the Gerardias and Foxgloves are quite parasitic, attaching their roots to those of other plants and getting part of their sustenance from them. One would little suspect such pretty plants of such pilfering. This species is found chiefly along the coasts of the Atlantic, the Great Lakes and the Gulf of Mexico. It blooms from August to October.

A more slender, smaller flowered species (G. tenuifolia) is found throughout the eastern half of the United States.

SMOOTH FALSE FOXGLOVE (Gerardia virginica) has a smooth, branching stem from 2 to 6 feet high. The leaves are lance-shaped, wavy-edged and usually toothed. The large, lemon-yellow flowers measure nearly two inches long by an inch broad. The plant grows from Me. to Minn. and southwards and blooms during August and Sept. The Fernleaved. Foxglove, (G. pedicularia) is smaller and has pinnatifid leaves. It is found in the same range. 


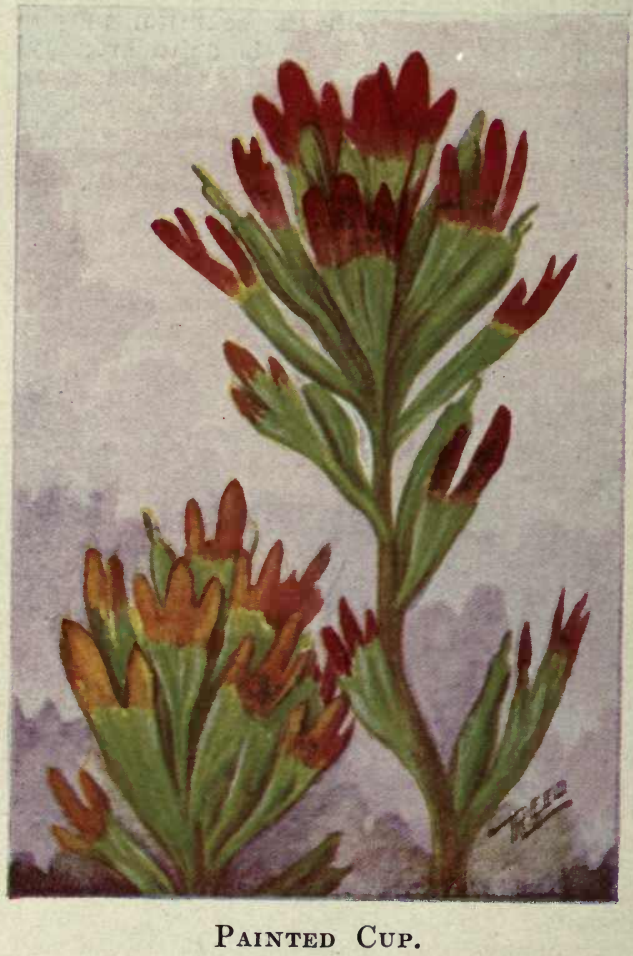

Castilleja coccinea. 
SCARLET PAINTED-CUP; INDIAN PAINT BRUSH (Castilleja coccinea). This singular species is a parasite, that is it fastens its roots upon those of other plants and takes their nourishment from them. Most plants of this nature have pale flowers and foliage, as instanced by Indian Pipe and Beech Drops, but the Gerardias, Foxgloves and the present species rank as among our most handsomely colored plants. This simply goes to show that plants may be deceitful, and that we can form no more idea of what goes on beneath the surface from their attractive appearance than we can judge a man's nature by his face.

The slender, hollow, reddish, angular and hairy stem grows from a tuft of smooth-edged, oblong leaves. The stem leaves are rather small and, the upper ones especially, have the ends three-lobed; those near and surrounding the flowers have their ends scarlet, as though they had been dipped in a pot of red paint. The flowers' corolla is almost concealed in the two-lobed cylindrical calyx, the end of which is usually a brilliant scarlet. The corolla is irregular, greenish yellow, with a narrow upper lip and a threelobed lower one. They have, set in the upper lip, four unequal stamens and a long pistil.

There is a great difference in the coloration of Painted Cup, apparently depending upon the nature of the soil and the light received. While most specimens are marked with the brightest of scarlet, we sometimes find it with yellow or even light green. The Scarlet Painted-cup is found in low sandy ground from Mass. to Manitoba and southwards. A paler species, C. pallida, is found in moist, rocky situations on hill or mountain sides from northern United States northwards. The stem leaves are usually entire, without lobes and the upper part of the stem is quite woolly. 


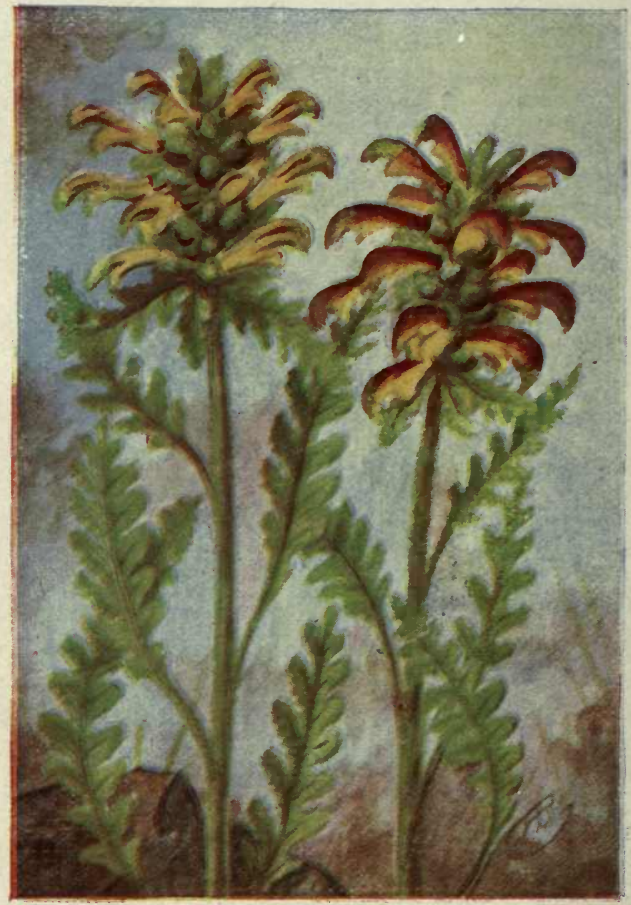

Wood Betony; Lousewort. Pedicularis canadensis. 
WOOD BETONY; LOUSEWORT (Pedicularis canadensis) is a peculiar plant that we find in dry woods and thickets and often along roadsides. It almost always has an unkempt appearance due chiefly to the fact that the florets grow from the flowering head with little regard to symmetry, and the leaves are rolled, folded, twisted or bent out of shape. It has many cognomens, one at least being undeserved, that of Lousewort, this being applied because of an early, mistaken belief of farmers that it had insects that infested sheep that fed upon its foliage. It is quite commonly called Beefsteak Plant because of the color of the upper lips of the flowers and because the leaves and stem are often stained with a purplish brown.

The flowering stems are stout, hairy and leafy; they rise to heights of 6 to 18 inches. The leaves are all fernlike in form; many of them rise on long hairy stems from the roots and smaller ones alternate up the flower stalk. The flower spike is short and densely flowered and contains many small bract-like leaves among the tubular flowers. The corolla is composed of two lips, the upper one being arched and strongly curved or hooked at the tip; four stamens are gathered under the shelter of the upper lip and a slender pistil projects through and beyond a small tooth or notch in the end of it; the lower lip is shorter, three-lobed and yellowish in color. The upper lip varies from a yellowish green in freshly opened flowers to a dull reddish on the mature blossoms, this latter being the beefsteak color alluded to in one of its common names.

Wood Betony is found from Nova Scotia to Manitoba and southwards. It is quite abundant throughout its range and its flowers may be found from early in May to the latter part of July. 


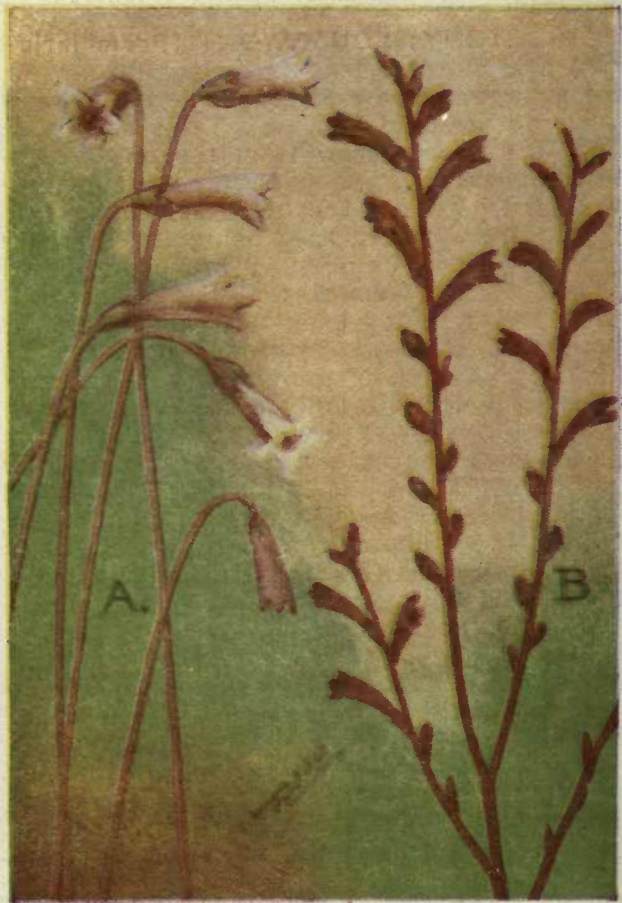

A. Beech Drops.

Epifagus virginiana.

B. Broom-RAPE.

Orobanche uniflora. 


\section{BROOM-RAPE FAMILY (Orobanchaceae).}

The members of this family are typical parasites, destitute of green foliage and practically colorless.

BEECH DROPS; CANCER-ROOT (Epifagus virginiana). This peculiar growth is found almost exclusively in beech woods. At first glance it might readily be taken for a little group of twigs projecting above the ground. The stalk is tough, brownish, erect and has several erect branches at the top. Along the lower part of the stem are a few scale-like bracts that represent the best the plant can do in the way of leaves.

The stems attains heights of 6 to 20 inches. At the ends of the branches are a number of curved, tubular flowers; these are stained a dull magenta. While they are perfect in all their parts, they are usually infertile. Just below the tubular blossoms are a number of tiny ones resembling buds. These are cleistogamous flowers that never open, but are fertilized without external agency.

Beech Drops attaches its roots to those of beech trees and gets all its sustenance from them. It blooms from August to Oct. and ranges from N. B. to Minn. and southwards

ONE-FLOWERED CANCER-ROOT; BROOM-RAPE (Orobanche uniflora) is an attractive little parasite with a subterannean scaly stem, that sometimes branches underground, each branch sending up one to four very slender stalks from 3 to 6 inches high and bearing at the top a single blossom each.

These terminal flowers are tubular and have five rounded lobes. Their color varies from a pale purple to a cream color and they average about threequarters of an inch in length. They are chiefly fertilized by small flies, attracted by the slight fragrance they emit. It is found in moist woods throughout the United States and southern Canada. 


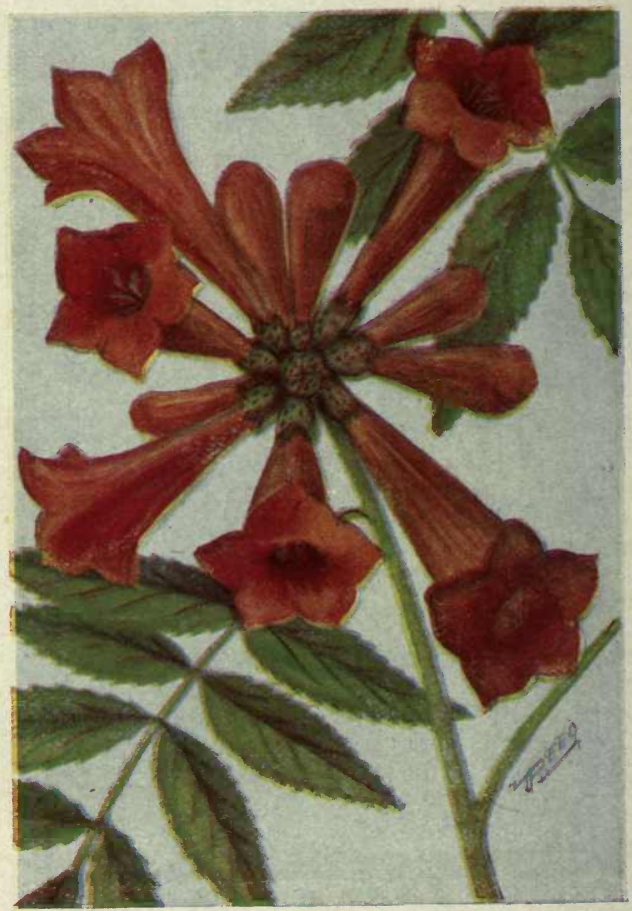

Trumpet Creeper.

Tecoma radicans. 


\section{Wild Flowers East of the Rockies}

\section{BIGNONIA FAMILY (Bignoniaceae.)}

A small family of woody plants having two-parted calyces and tubular, five-lobed corollas, the lobes somewhat irregular, the lower one usually being the largest.

TRUMPET CREEPER (Tecoma radicans) is an exceedingly beautiful woody vine having a southern disposition, in fact all the members of this family are rather tropical in their habits.

Audubon in his plate of the Ruby-throated Hummingbirds shows them about a cluster of flowers of this vine. His choice was well made for it is one of the favorites with these tiny birds. I have spent hours, in Virginia, in watching these beautiful creatures hovering, with whirring wings, at the door of each blossom in turn. In order to reach the nectar at the base of the long tube he has to force himself well into the flower so that it conceals his head and shoulders.

The stem of this species grows from 20 to 40 feet long and is either prostrate or climbing. Sometimes it extends over the ground, climbing over the bushes that may be in its path, and again it may take an upward course and climb the trunks and branches of small trees. As it is a hardy plant it is often seen in cultivation and is used to decorate porches in the North.

The flowers are trumpet-shaped, red within and tawny or orange on the outside of the tube. They grow in terminal clusters of two to nine blossoms, each in a cup-shaped, two-parted calyx. The corolla is about $2 \frac{1}{2}$ inches long and flares into five rounded lobes. Four anther-bearing stamens and a pistil are in the upper part of the tube. The leaves grow oppositely on the stem and are each composed of 7 to 11 ovate, toothed leaflets. We find this vine from N. J. to Ia. and southwards. 


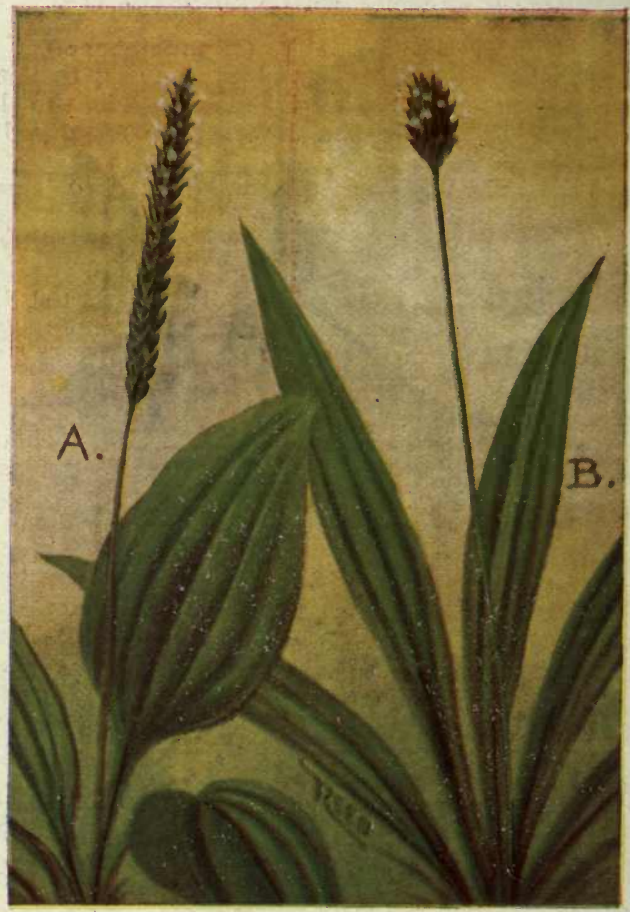

A. Common Plantain.

Plantago major.

B. English Plantain.

Plantago lanceolata. 


\section{PLANTAIN FAMILY (Plantaginaceae).}

A small family of despised weeds with coarse toothless leaves clustered at the root and tiny flowers on a coarse spike.

ENGLISH PLANTAIN (Plantago lanceolata) is one of the most common flowering weeds about dooryards everywhere. It is only because of its very abundance that it has been given a place in this volume, certainly not because of its beauty for it is one of our most inconspicuous weeds in flower. It is regarded as a pest by real estate owners who take pride in the appearance of their yards. It is very prolific and very difficult to eradicate.

The leaves all radiate from the base; they are lanceolate, sharply pointed and set on long, troughed stems; they are dark green in color and are strongly ribbed lengthwise.

The flower stem is stiff and smooth and attains heights of 6 to 18 inches. The head is short and studded with tiny, four-parted, dull white flowers, with long, slender stamens There are often perfect, staminate and pistillate flowers on the same plant. It is now as abundant in all parts of our range as it is in its native European home.

COMMON PLANTAIN (Plantago major) is, like the last, a very familiar weed about ill-kept dooryards. The leaves are larger, more spreading and not as erect; they are broad-oblong and on long troughed stems that radiate from the root.

The flower stalk rises to about the same height as the last, but the flower head is very long. The tiny white flowers open in circles about this head, slowly making their way towards the top in their succession of bloom, which lasts from June until September. 


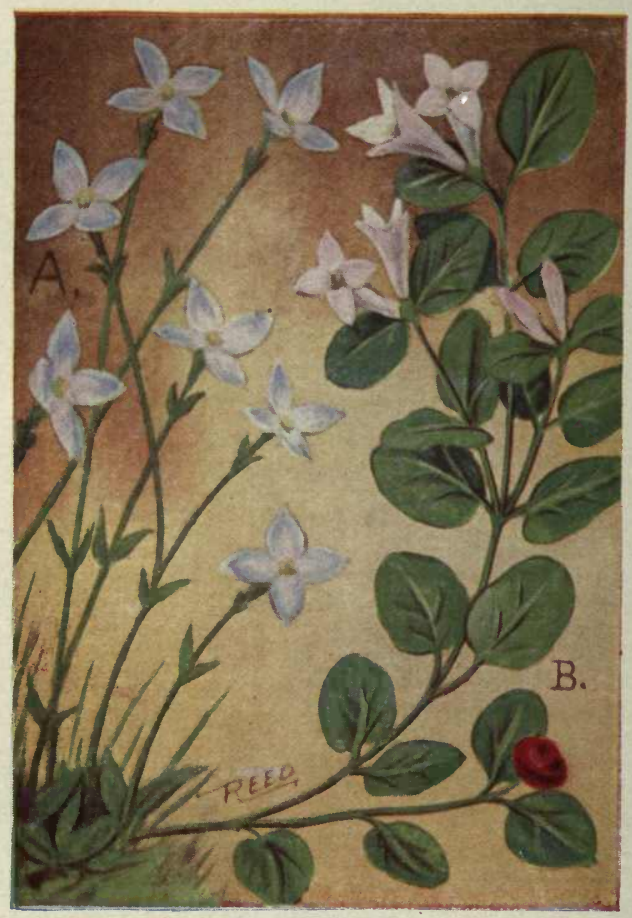

A. Bluets; Innocence. Houstonia caerulea.

B. Partridge Vine; Twinberry. Mitchella repens. 


\section{MADDER FAMILY (Rublaceae).}

A large family of shrubs or herbs with opposite or whorled leaves having entire edges. The flowers are regular, perfect and usually four-parted, with the same number of stamens as divisions to the corolla. The family includes the Coffee Plant and the Peruvian bark trees.

BLUETS; INNOCENCE (Houstonia caerulea). These are very dainty and beautiful little plants that decorate our fields profusely from April until July. They frequently grow in such large patches that, from a distance, the ground appears as though covered with snow of a bluish or pale violet shade. The stems are very slender, about 3 to 6 inches tall, and have a few pairs of tiny leaves; larger leaves appear in tufts from the base. Usually each stem bears but a single four-parted blossom at the top. The perianth is slender and the lobes flare widely; the corolla is about one half inch in width,-white, with the ends of the lobes pale blue or violet, and stained with yellow towards the center of the flower. They are crossfertilized by small bees and little butterflies. The species is very abundant from N. S. to Manitoba and southwards to the Gulf.

PARTRIDGEBERRY (Mitchella repens) is a most beautiful little trailing vine with rounded, opposite, white-veined leaves along the creeping stem, that extends 6 to 12 inches from the root. Two beautiful little four-parted, bell-shaped flowers terminate each branch. They are downy white within, and pinkish and smooth on the outside. They have a fragrance similar to that of the Water Lily. A double, red berry replaces the flowers in the Fall; at this season, the plants are collected extensively for use in ferneries, as their leaves are evergreen. It is common in woods throughout our range.

BEDSTRAWS (Gallium) have weak, square, bristly stems, tiny four-parted flowers and whorled leaves. 


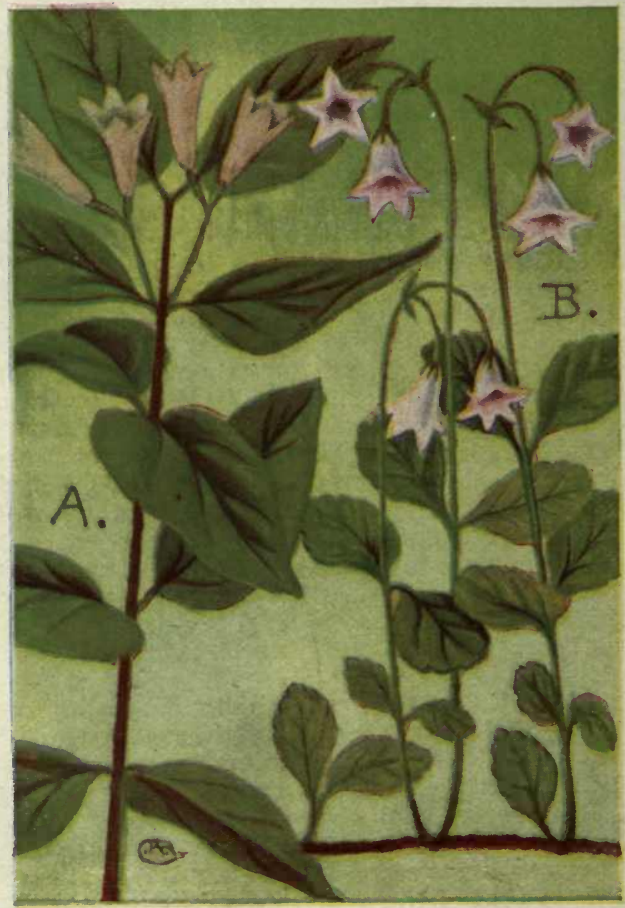

A. Fly Honeysuckle.

Lonicera canadensis.

B. Twin-Flower.

Linnaea borealis. 


\section{HONEYSUCKLE FAMILY (Caprifoliaceae).}

A family composed of shrubs, vines or herbs with opposite leaves and perfect, usually regular flowers of a funnel-form.

FLY HONEYSUCKLE (Lonicera canadensis) is a bush or shrub with thin, straggling, brown branches, attaining heights of 2 to 4 feet. The leaves are thin, light green, somewhat heart-shaped and short stemed. They grow oppositely on the branches and have small stipules between them. The flowers are borne in pairs from the axils of the terminal leaves. The Naples yellow tubes are about three fourths of an inch in length and have five lobes. The pairs of blossoms are joined to the slender peduncles with exceedingly short stems. After the flowering season, two bright red berries, with their bases touching but not united, take the places of the pairs of flowers. This species is common from Quebec to Manitoba and south to Pa. and Mich.

A similar species, the Mountain Fly Honeysuckle (L. caerulea) has the pairs of flowers almost united at their bases and the berries united into a single one with two "eyes." This is also common in low woods in the same range.

TWINFLOWER (Linnaea borealis americana) is one of the most delicately beautiful of our wild flowers. The stem is slender, trailing, reddish-brown and from 6 to 24 inches long; at intervals very slender, leafy flower stalks rise, bearing at the end, two pendulous, bell-shaped, white, fragrant blossoms; the corolla, which has five lobes, is crimson pink within. The evergreen leaves are short-stemmed, almost round and scallop-toothed. It was a favorite plant with Linnaeus and is named after him. It is also highly prized by all who reside in, or visit, the sections it frequents. It blooms in July and August in cool mossy woods from Lab. to Minn. and south to $\mathrm{Pa}$. in the mountains. 


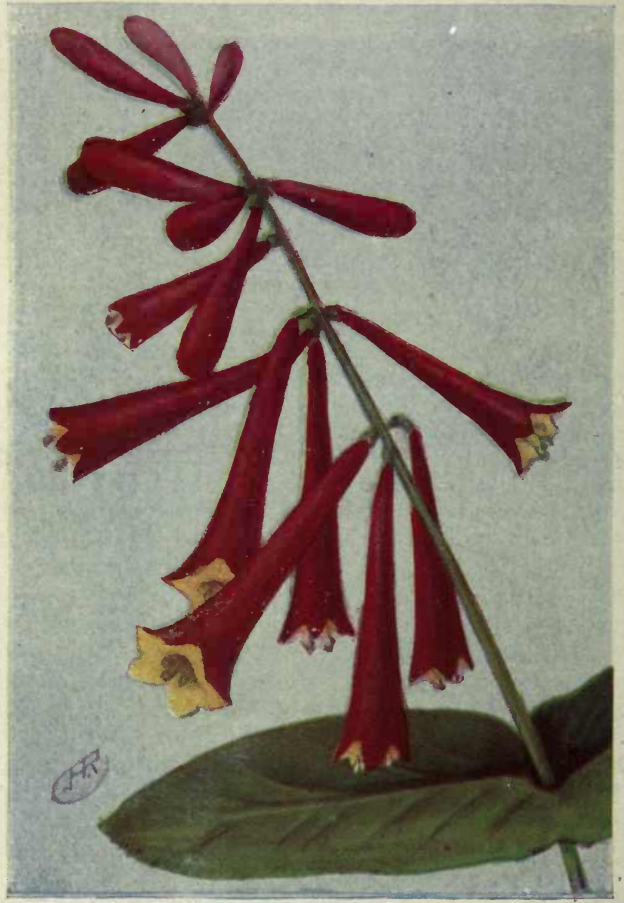

Coral Honeysuckle.

Lonicera sempervirens. 
CORAL OR TRUMPET HONEYSUCKLE (Lonicera sempervirens) is a very ornamental, climbing, woody vine growing from 8 to 15 feet in length. It trails over bushes or entwines its stems about the branches of trees. It is more slender and graceful than the Trumpet-creeper and, while its flowers are not as large as the latter, they are brightly colored so that the species is fully as often seen in cultivation as the Trumpet-creeper. The lower leaves have short stems, are rounded-oval in shape and opposite, as are those of all the members of this family. The leaves near the ends of the branches are united at their bases, clasping the stems and forming cup-shaped structures. The strikingly colored flowers grow in whorls on spikes terminating the branches. The tubular corollas are about two inches in length, bright red on the outside and yellow within; the opening of the corolla spreads but very little and is five-lobed. As may be seen from the picture on the opposite page, this honeysuckle flaunts the favorite colors of the Ruby-throated Hummingbird and is consequently visited very often by these birds. Its long slender corolla is perfectly adapted to the long bill and tongue of this smallest of our birds. In the South the leaves of the Coral Honeysuckle are evergreen but in the North they are deciduous. In the Fall where each flower was located during the Summer we find an orange-red berry. These are eaten by various migrating birds and in this manner the seeds contained in the berries are scattered over a wide range of territory. This is one of Nature's surest ways of increasing the range of a species and adding to its vitality by bringing it into contact with the same kind of plants from widely separated localities. This species is distributed from Conn. and Nebr. southwards. 


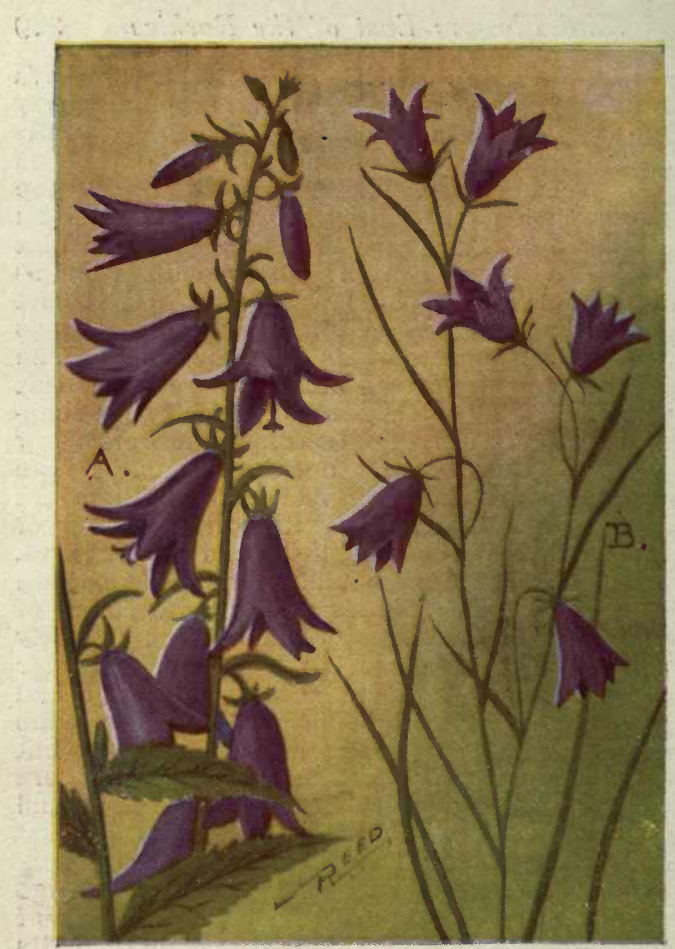

A. Bellflower.

Campanula rapunculoides.

B. Bluebell; Harebell.

Campanula rotundifolia. 


\section{BLUEBELL FAMILY (Campanulaceae).}

A small family of herbs with alternate leaves and acrid, usually milky, juices. The flowers are regular and perfect and have a five-parted, usually bellshaped, corolla.

BELLFLOWER (Campanula rapunculoides( (EUROPEAN). This beautiful European species is a frequent escape from gardens and is quite firmly established in several localities in the Eastern States. It is, of course, to be met with in the vicinity of habitations and often alongside roads. As it is a perennial its occurrence in the same places may be looked for year after year.

The simple stems are erect and quite tall, ranging from 1 to 3 feet high. The toothed, lance-shaped leaves alternate along the lower portion of the stem and the bell-shaped, purplish flowers are in loose spikes on the terminal portions. They are all in nodding positions, seated in five-parted calyces, on slender pedicels each subtended by a small bract-like leaf.

HAREBELL; BLUEBELL (Campanula rotundifolia) is the "Blue Bells of Scotland" so familiar to us in song and verse. It is a very slender-stemmed species but very hardy, as attested by the altitudes at which it is found on mountains. It gets it specific name, rotundifolia, from the little tuft of rounded, toothed leaves that appear before the flowering stem, and rarely last until the flowers appear. The flowering stems are very slender and wiry, sparsely set with linear leaves; they usually branch near the summit, each division bearing a demure, drooping, violet bell. It is found in bloom from June until September in rocky or sandy places in Canada and northern United States.

VENUS' LOOKING GLASS (Specularia perfoliata) is a tall, wand-like annual with rounded, scallop-edged clasping leaves and little 5-parted blue flowers in their axils. Found throughout the United States. 


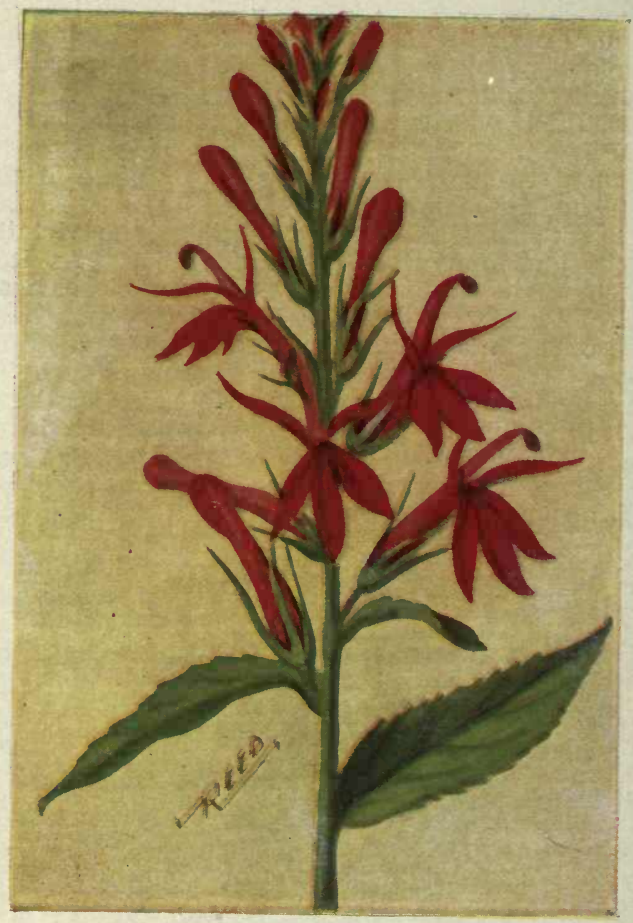

Cardinal Flower.

Lobelia cardinalis. 


\section{Wild Flowers East of the Rockies}

\section{LOBELIA FAMILY (Lobeliaceae).}

A small family of herbs with acrid, milky juices, alternate leaves and loosely spiked, or scattered, irregular flowers.

CARDINAL FLOWER (Lobelia cardinalis). Although exceedingly bright colored, these flowers are rightly classed as among our most beautiful wild ones; they have a grace of form and a clearness of color that charms everyone. They dispute with Oswego Tea the title of supremacy in the brilliance of their scarlet coloring. As might be expected from their color, they are visited by and chiefly fertilized by the Ruby-throated Hummingbird.

The simple stem grows to heights of 2 to 4 feet from perennial creeping rootstalks that often throw up new plants; the stalk is hollow and rather closely set with alternating, lance-shaped leaves, the lower ones stemmed and toothed, the upper ones clasping the stem and nearly smooth-edged. The showy flower-spike is loosely set with bright red flowers; the narrow, tubular corolla proceeds from a five-parted calyx, and ends in two lips, the upper having two erect, narrow lobes and the lower a broad three-cleft one, velvety-scarlet; the five stamens are united in an erect tube. The Cardinal Flower is found in moist ground, especially along brooks, blooms in August and September and is found from N. S. to Minn. and southwards.

GREAT LIBELIA (Lobelia siphilitica) has a simple, stout, hairy and leafy stem 1 to 3 feet high. The leaves are oval, toothed and short-stemmed and gradually decrease to the size of bracts at the top of the stem. The light blue-violet flowers appear in the axils of the upper leaves. They are nearly an inch long, two-lipped, the lower one having three spreading lobes and are seated in rather large, rounded calyces. It is common in low, moist ground from Me. to Minn. and southwards; it may be found in bloom from July until September. 


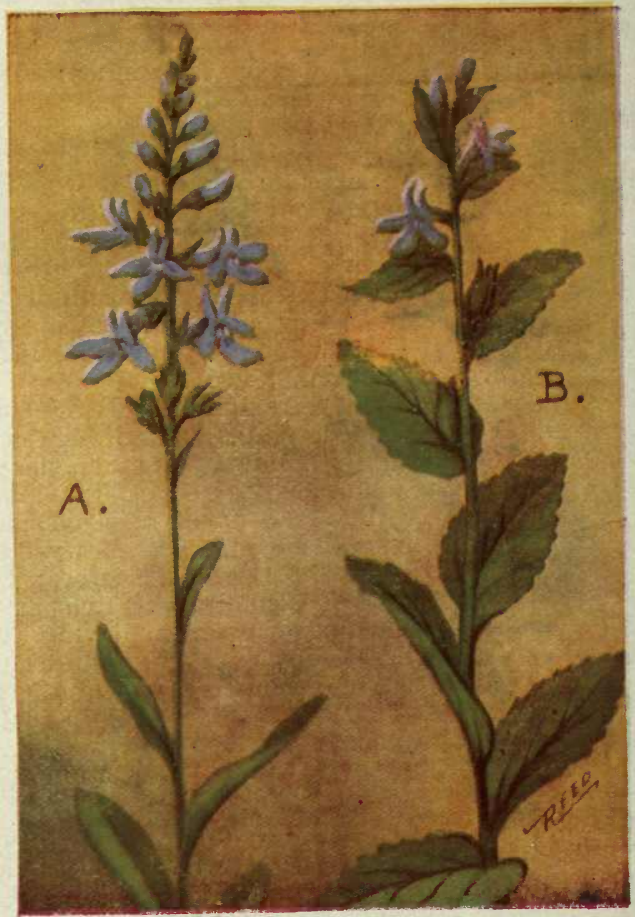

A. Spiked Lobelia.

Lobelia spictata.

B. Indian Tobacco.

Lobelia inflata. 
SPIKED LOBELIA (Lobelia spicata) is a smaller flowered species having a simple leafy stem from 1 to 4 feet in height. The leaves vary greatly in shape from lance-shaped to oblong, and decrease in size rapidly as they approach the flower spike. The small, pale blue-violet flowers are set in short smooth calyces. The upper lip of the corolla has two small lobes and the lower one is divided into three, larger, spreading ones. It is commonly found in dry, sandy soil from N. S. to Manitoba and southwards.

INDIAN TOBACCO (Lobelia inflata) is the most common of the Lobelias; it is found growing everywhere in either sandy or moist soil, in woods or in fields. The alternating leaves are pointed-oval and sparingly wavy-toothed; the lower ones are quite large, while the upper ones are very small. The simple stem is stout and quite hairy; it grows from 1 to 2 feet in height. The little blue-violet flowers are barely one quarter inch long, each seated in a large, smooth inflated calyx. This species of Lobelia is used very freely in the compounding of various medicines and, in one form or another, is supposed to cure a great many of the ailments of mankind. The leaves were used by Indians for chewing, but have a very nauseating taste; they have poisonous properties and will cause ill effects if swallowed.

The flower calyces enlarge still more after the corollas have withered away, and form round seed pods that follow closely up the stem on the heels of the flowers, for the succession of bloom is from the bottom of the spike towards the top.

WATER LOBELIA (Lobelia Dortmanna) is a species found on the borders of ponds or even in the water. The flowers are similar to those of the other species, but the leaves are thick, linear and in a tuft at the base of the hollow stem. It is quite common from N. E. and N. Y. northwards. 


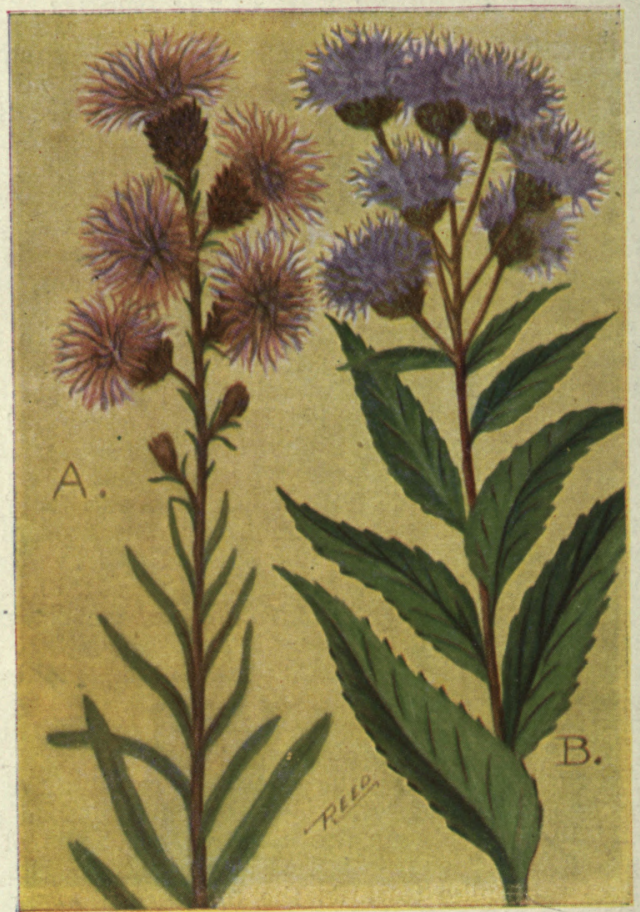

A. Blazing Star.

Liatris scariosa.

B. IRONWEED.

Vernonia noveboracensis. 


\section{Wild Flowers East of the Rockies}

\section{COMPOSITE FAMILY (Compositae).}

TALL BLAZING STAR (Liatris scariosa) is a tall, handsome perennial that throws up its beautiful spike of blossoms in Fall, together with those of the Asters and Golden-rods. The plant usually grows in dry situations and attains heights of 2 to 6 feet. A long spike containing numerous, quite large, flower heads adorns the top of the stem. These heads, which are about $3 / 4$ in. in diameter, have a very disheveled. appearance for the magenta-purple rays emerge in all directions; they are contained in a large imbricated involucre. The leaves are stiff, lanceolate, and closely alternated along the stem, the upper, small ones, acting as bracts for the flower heads.

The Blazing Star furnishes another welcome color to add to the many hues of the late flowers that so plentifully bedeck our land. It is found from Me. to Mich. and southwards. A more common species, (Liatris spicata) has smaller flower heads, set in a longer spike and has linear leaves. It is found from Mass. to Minn. and southwards.

IRONWEED (Veronia noveboracensis) is a tall (3 to 7 feet) and smooth-stemmed member of the Composite Family. The alternating leaves are lanceolate and finely toothed. The flower heads are grouped in flat-topped clusters. The rays are slender and very numerous, giving the heads the appearance of little thistles. This species blooms in August and September, at which season it is one of the characteristic plants in moist ground near the seashore. Other similar species are found in the central portions of the country, notably $\mathrm{V}$. altissima, which is common from N. Y. to Mich. and southwards. 


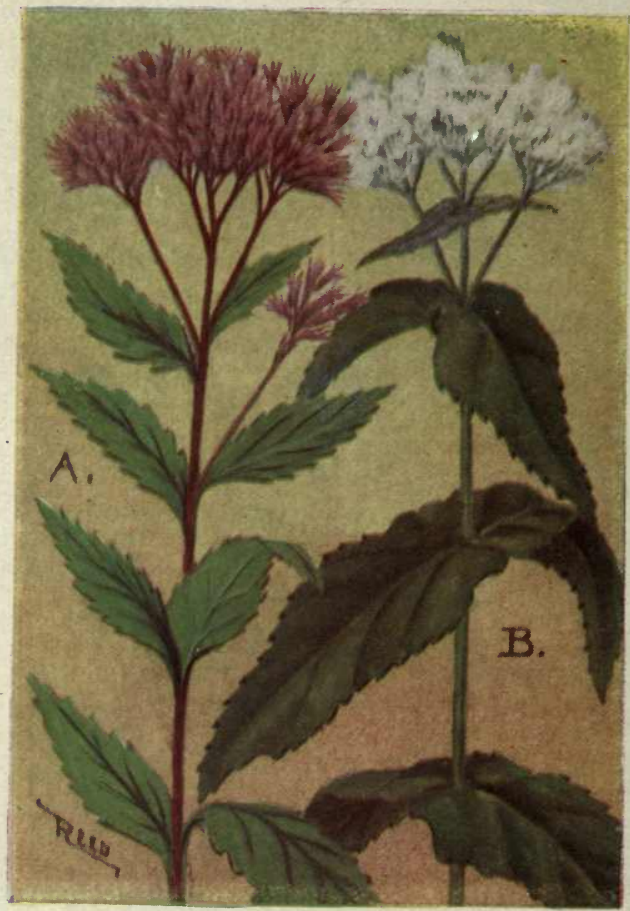

A. Joe Pye Weed.

Eupatorium purpureum.

B. Thoroughwort; Boneset. Eupatorium perfoliatum. 
JOE PYE WEED (Eupatorium purpureum) is a very familiar and pretty species, found commonly everywhere along the edges of swamps, thickets or about ponds. The simple, rather slender, stem is very tall, attaining heights of from 2 to 10 feet. The stem is usually stained purplish and is set at intervals with whorls of three to six, rough, coarselytoothed leaves; these latter have short stems, rather broad bases and are sharp-pointed. The flowers grow in flat-topped terminal clusters. Each floret is of a rosy purple color and has projecting styles that give the flowers a very fuzzy appearance. The color, which is very nearly like that of the common Milkweed, causes many to confuse this plant with that species, although they are very dissimilar in every other respect.

Each little tubular floret yields a drop of nectar and is, consequently, highly appreciated by many species of butterflies as well as by bumblebees. Its common name is that of a quack Indian doctor who made frequent use of this plant for the "cures" of various ailments.

Joe Pye Weed is commonly found in moist places from Newfoundland to Minn. and southwards, flowering during August and September.

THOROUGHWORT; BONESET (Eupatorium perfoliatum) is a flowering herb, dearly beloved by the old-fashioned housewife and equally detested by the small boy. It was, and still is, one of the most commonly used home remedies and doubtless is quite often efficacious in producing, or conducing to, cures of colds, chills, slight fevers etc. The stem is stout, hairy and 1 to 5 feet tall. The opposite leaves are perfoliate, that is the ends are joined together. It is very common in swamps or thickets everywhere. 


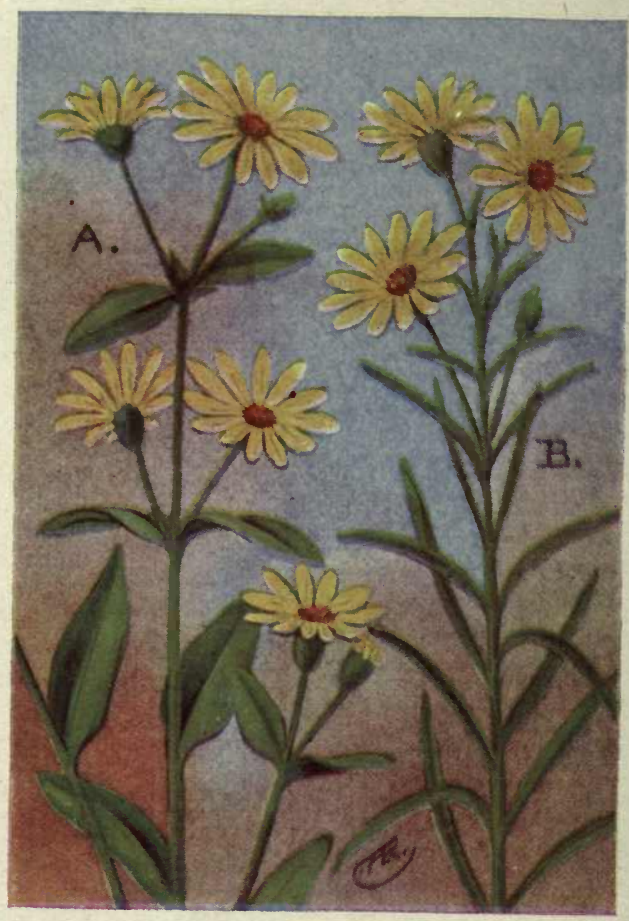

A. Golden Aster.

Chrysopsis mariana.

B. Lance-leaved Golden Aster.

Chrysopsis falcata. 
CURVED-LEAVED GOLDEN ASTER (Chrysopsis falcata) is a very beautiful species with a silvery, woolly stem 4 to 10 inches high, closely crowded with stiff, linear, downy, slightly recurved leaves. The golden-yellow flowers spread about an inch; the tubular florets in the center have a brownish orange tinge but the numerous straps or ray-flowers are the brightest of orange-yellow. This species loves dry sandy soil and is most abundant near the coast from Cape Cod to the pine barrens of New Jersey. It may be found in bloom from the latter part of July until September.

GOLDEN ASTER (Chrysopsis mariana) is, as one would judge from its species name, very partial to the seacoast, where it may be found in profusion in dry sandy places and along roadsides.

It is to me, an even more beautiful species than the preceding. It is a larger, more rugged plant, growing from 1 to 2 feet tall. The stem is quite branchy and is rather closely set with lance-shaped stemless, graygreen leaves. The flowers, however, are just a trifle smaller than those of the last species; they grow in rather loose, flat-topped clusters, each head being on a rather long, slightly sticky peduncle. The tubular and ray florets proceed from a bell-shaped involucre composed of closely overlapping bracts, a formation quite characteristic of members of this family. This species is not as closely confined to the immediate seashore as is the last and may even be found in dry woods. Its period of bloom is during August and September and it ranges from N. Y. and $\mathrm{Pa}$. southwards to Fla. and La.

Another species (C. villosa), with hairy stems and leaves, is found on dry plains and prairies from Manitoba southwards to the Gulf. 


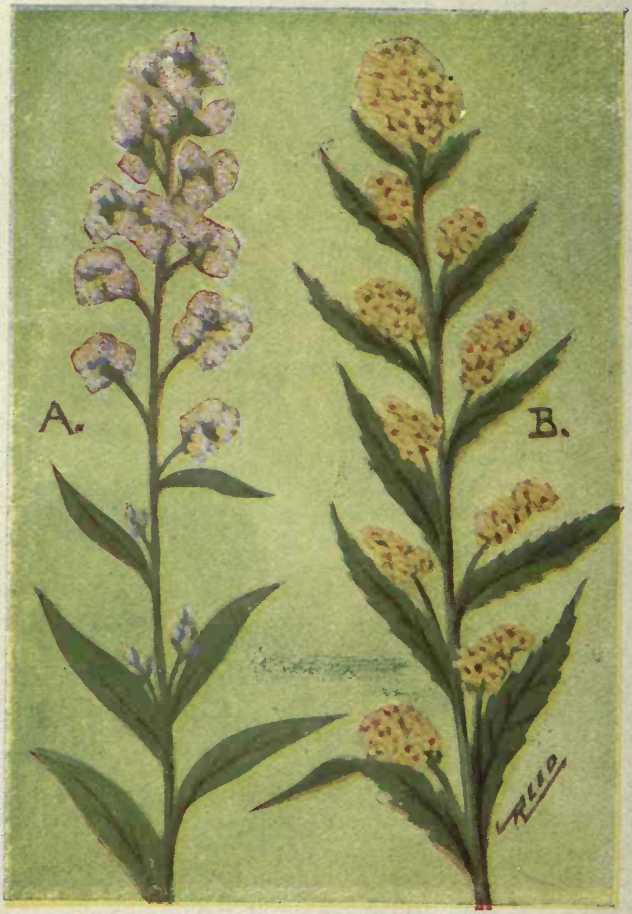

A. White Golden-rod; Silver-rod. Solidago bicolor.

B. Blue-stemmed Golden-rod. Solidago caesia. 


\section{GOLDEN-RODS; Genus (Solidago).}

The Genus Solidago is a very large one, comprising more than eighty species. They are the most familiar and abundant of our Fall flowers. The flowers are always in clusters and with one exception they are yellow or golden. The most common forms have a simple wand-like stem topped with a long golden spike, readily suggesting the common name of Golden-rods.

\section{SILVER-ROD; WHITE GOLDEN-ROD (Solidago} bicolor) bears the distinction of being the only one of our very numerous Golden-rods that does not have golden flowers. Those of this species are white or cream-colored. The stem is usually simple and attains heights of from 10 to 30 inches. It is downy and is rather closely set with rough, elliptical, slightly toothed leaves. The clusters of flower heads grow in racemes from the axils of the upper leaves or in a cylindrical terminal spike.

The cream-yellow tubular florets are surrounded by from three to twelve white rays. As a rule, the flower heads are not as closely crowded together as in other species. Silver-rod blooms during August and September on dry ground, frequently along roadsides or the edges of woods, from N. B. to Minn. and southwards to the Gulf.

\section{BLUE-STEMMED GOLDEN-ROD (Solidago cae-} sia) blooms during Sept. and Oct. The simple stem is closely set with lanceolate, toothed leaves, and from the axils of those on the upper half of the stem, appear loose racemes of flowers. The heads are rather larger than those of most of the Goldenrods and have from three to five, comparatively long, golden rays surrounding the tubular florets.

This species has a somewhat bluish or purplish cast to the stem; the arrangement of the flowers, from the axils of the leaves, will serve best to identify it however. 


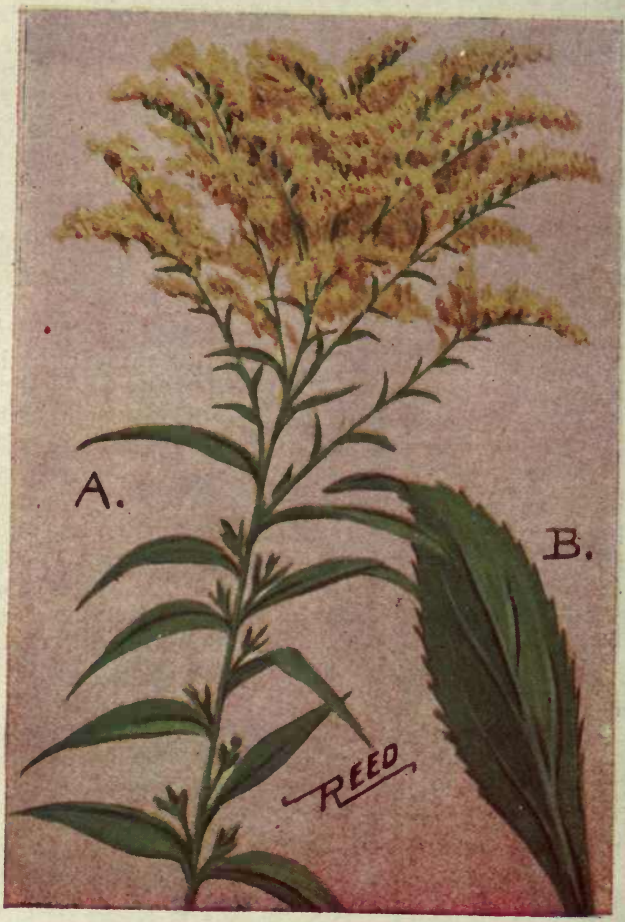

Early Golden-rod. Solidago sempervirens. 


\section{Wild Flowers East of the Rockies}

EARLY GOLDEN-ROD (Solidago juncea) is a very common species and one of the earliest to bloom, being found in flower from July until Sept. The flowers are in a large graceful cluster, composed of numerous racemes, at the summit of a tall, simple stem 2 to 4 feet high. The stem is smooth, angular and usually a ruddy brown. The leaves are smooth, lance-shaped; the lower ones toothed, but the upper with nearly even edges. The golden-yellow flowers have eight to ten rays. Found in dry places from $\mathrm{N}$. B. to Sask. and southwards.

SEASIDE GOLDEN-ROD (Solidago sempervirens) is a common species of the salt marshes from Me. to Fla. It has a large, showy flower cluster, and the flowerheads, individually, are also quite large; they have 7 to 10 rays. The lanceolate leaves are tootnless and slightly clasping at their bases. The smooth, stout stem grows from 2 to 8 feet tall.

ROUGH-STEMMED GOLDEN-ROD (Solidago rugosa) is a very hairy species, rough to the touch. The stem attains heights of 1 to 7 feet and often branches at the top. The flower racemes spread in a broad pyramidal panicle. The pale golden-yellow flowers have 6 to 9 rays. The leaves are feather-veined, quite hairy and coarsely toothed. Common in fields and on the borders of woods and thickets from Newfoundland to Minn. and southwards.

CANADA GOLDEN-ROD (Soligado canadensis) is perhaps the most common and the handsomest of the genus. The flower cluster is very large and plume-like. The leaves are thin, narrowly lanceolate and finely toothed. The rather slender stem ascends to heights of 2 to 7 feet. The flowerheads are rather small, but are closely crowded on the curving peduncles. This is a very common species throughout our range. 


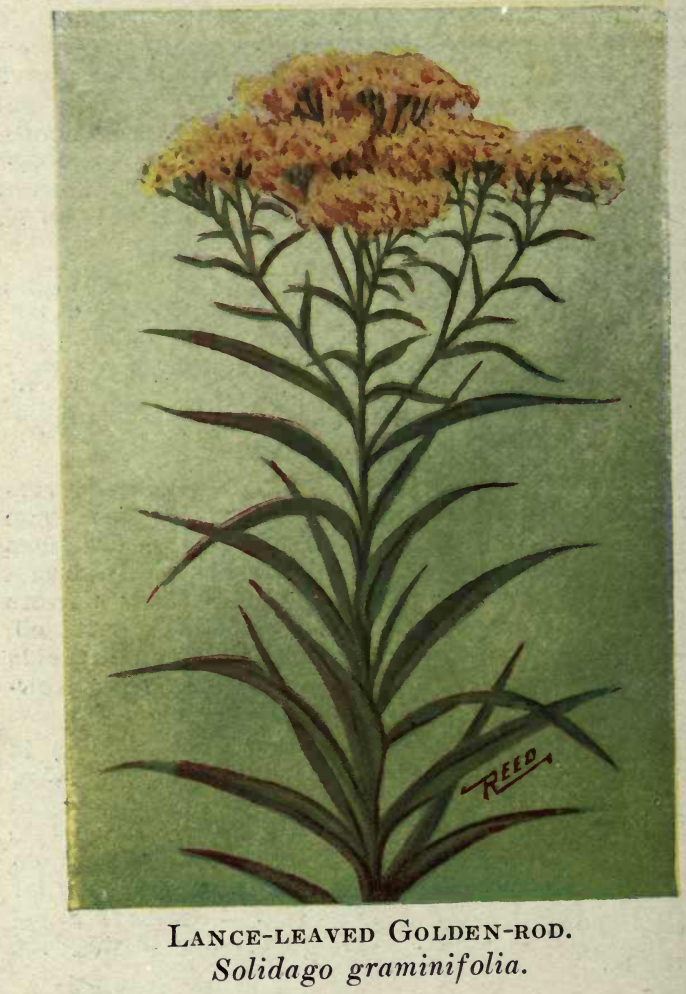


LANCE-LEAVED GOLDEN-ROD (Solidago graminifolia). This species differs greatly in appearence from the usual form of most of the Golden-rods; in fact the difference in form is even more pronounced than that of the Blue-stemmed variety, and is so great that many botanists favor the forming of a new Genus for it. It is a very common species and is found everywhere, either in moist or dry situations.

The stem is simple, angular and slightly rough; it ascends 2 to 5 feet and near the summit sends up many slender wiry, leafy branches supporting flattopped flower clusters. The flowers are crowded closely together but are very small and rather dullcolored; they have 12 to 20 minute rays. The leaves are small and narrowly lanceolate; they have three to five ribs and are toothless but have a rough edge. It blooms from August until October, very commonly from N. S. to Sask. and southwards to N. J. and Mo.

SLENDER GOLDEN-ROD (Solidago tenuifolia) is a somewhat similar species with narrower leaves, linear-lanceolate, usually one-ribbed and minutely dotted. The stem is smooth and more slender; it grows from 1 to 3 feet high. The flowers are in a flat-topped cluster, each head having 6 to 12 tiny rays. It is found in sandy soil, chiefly near the coast, from Mass to Fla.

SHOWY GOLDEN-ROD (Solidago speciosa) is a large species, from 3 to 7 feet tall, with a stout simple stem and a magnificent, bright golden-yellow, plume-like head; the flowers are comparatively large and have usually five rays. Readily distinguished by its leaves, the lower ones rather large, contracting into a margined stem, gradually decreasing in size to small lance-shaped ones at the top of the stem. 


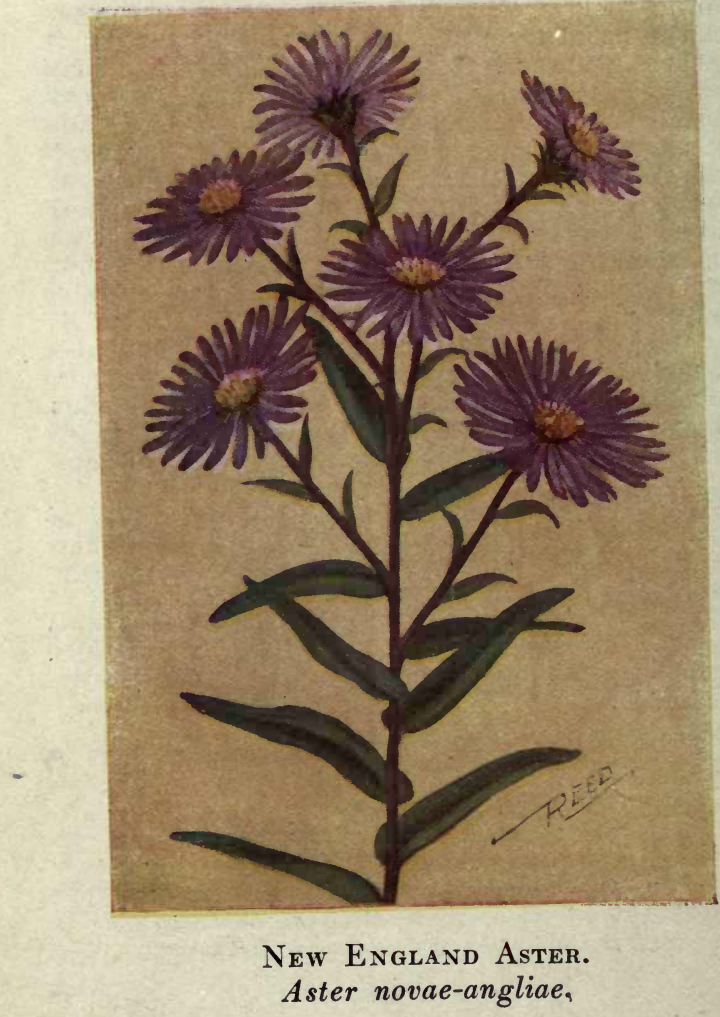




\section{Wild Flowers East of the Rockies}

\section{THE ASTERS. Genus (Aster).}

The members of this genus are exceedingly numerous in species. Collectively they greatly outnumber all the rest of the family combined. They are very variable; some have large flower heads, others tiny ones; some are quite tall, others barely rise above the ground; some have few flowers on a plant while on others they are exceedingly numerous. Their colors are usually some shade of purple or white. They all yield an abundance of nectar and are frequented by numerous small bees. The tubular flowers, those on the disc, or "button", in the center of the flower, are regular and perfect; the ray florets are pistillate.

The flowers are so numerous and vary so greatly, one type gradually merging into another, that they form a confusing Genus. The latest edition of Gray's Botany describes 57 species; we refer anyone to this work if they wish to learn the specific name of every species. We will describe a few of the distinct and most common types.

NEW ENGLAND ASTER (Aster novae-anglae) is one of the largest of the genus, its stem attaining heights of from 2 to 6 feet; it is also one of the most common and most popular species.

The stem is stout, branched and rather rough. The leaves are soft, hairy, lance-shaped and clasp the stem by a somewhat heart-shaped base. The flowers are in a broad corymb at the top of the stem. They are quite large, measuring about an inch across; the 30 to 40 narrow rays are of a purplish color, often quite bright.

This species is not, as might be judged from its name, a native of New England, only, but is common from Me. to Minn. and southwards, blooming from August to October, frequenting dry ground. 


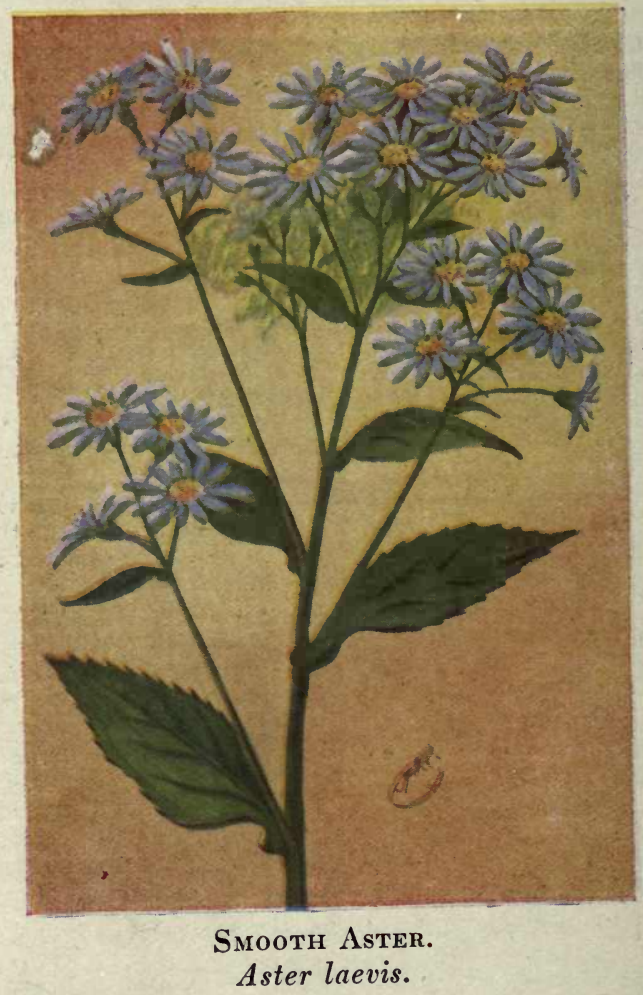


SMOOTH ASTER (Aster laevis) is a handsome species having a smooth, stout stem, quite branching, usually covered with a whitish bloom and growing from 2 to 4 feet high. The flowers are in lovely terminal clusters, each blossom measuring about an inch across; they are usually light violet blue in color, although color is very variable with all the so-called blue asters; each disk is surrounded by 15 to 30 rays. The leaves are nearly smooth-edged, lanceolate, clasping the stem with a distinct heart-shaped base. The Smooth Aster is abundant from Me. to Minn. and southwards, growing in dry soil and blooming. in September and October.

NEW YORK ASTER (Aster novi-belgii) is one of the very commonest of the "blue asters." The stalk is slender, very branchy and grows from 1 to 3 feet in height. The leaves are commonly narrowly lanceolate but are very variable; they slightly clasp the stem with their bases. The numerous flower heads are a trifle more than an inch across, the yellowish center being surrounded by 15 to 24 lilac or blueviolet rays. This species abounds from Newfoundland to Florida and perhaps west to the Miss. Valley. It blooms in September and October.

PURPLE-STEMMED ASTER (Aster puniceus) is more widely distributed and perhaps as abundant as the last species. It is tall and branching, the stem growing from 2 to 7 feet in height. The stalk is brownish purple and is stout and rough-hairy. The leaves are large, oval, with a tapering point, rough above and hairy on the midrib below, coarsely but sparingly toothed. The flowers grow very profusely in terminal clusters. The centers are dull yellow and the 20 to 24 rays, light violet blue or white. Common from N. B. to Manitoba and southwards. 


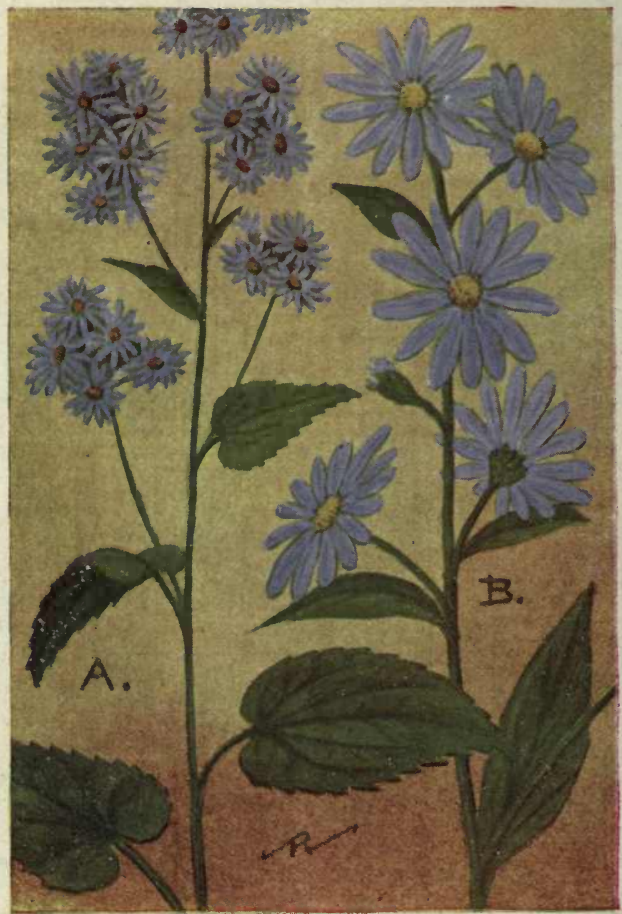

A. Heart-leaved Aster.

Aster cordifolius.

B. Panicled Aster.

Aster paniculatus. 
HEART-LEAVED ASTER (Aster cordifolius) is a common species, readily identified by the shape of its leaves that are, the lower ones especially, heartshaped and on quite long, slender, ciliate petioles; they are thin but rather rough and are toothed on the edge. The stalk is slender, branchy and grows from 1 to 4 feet high. The flowers are numerous but comparatively small, about $5 / 8$ inches across; they have brownish yellow centers and 10 to 20 lilac, or lighter colored rays. It is a very common species in thin woods and thickets, or along their edges, or roadsides. Found from N. B. to Minn. and southwards, flowering in Sept. and Oct.

WAVY-LEAVED ASTER (Aster undulatus) is also readily identified because its leaves have long, broad stems that expand into heart-shape as they clasp the stem. The stems are stiff, rough and 1 to 3 feet tall. The light, blue-violet flowers have 9 to 15 rays. This species ranges from N. B., Ont. and Minn southwards.

PANICLED ASTER (Aster paniculatus) is a very tall, branching, slender-stemmed species, commonly found in moist ground and on the borders of woods or copses. The smooth stalk attains heights of from 2 to 8 feet. At the ends of the branches are numerous flower heads about the size of a nickel, loosely panicled. The leaves are long lance-shaped, nearly smooth, obscurely, or not at all, toothed and dark green in color. This is one of the palest colored of the "blue asters," the flowers are very light violet and often white.

SHOWY ASTER (Aster spectabilis), a seaside species, has probably, the deepest colored flowers; large, about $1 \frac{1}{2}$ in. across, deep purplish violet and but few in number. Simple stem 1 to 2 feet tall and rough, toothless, lance-shaped leaves. 


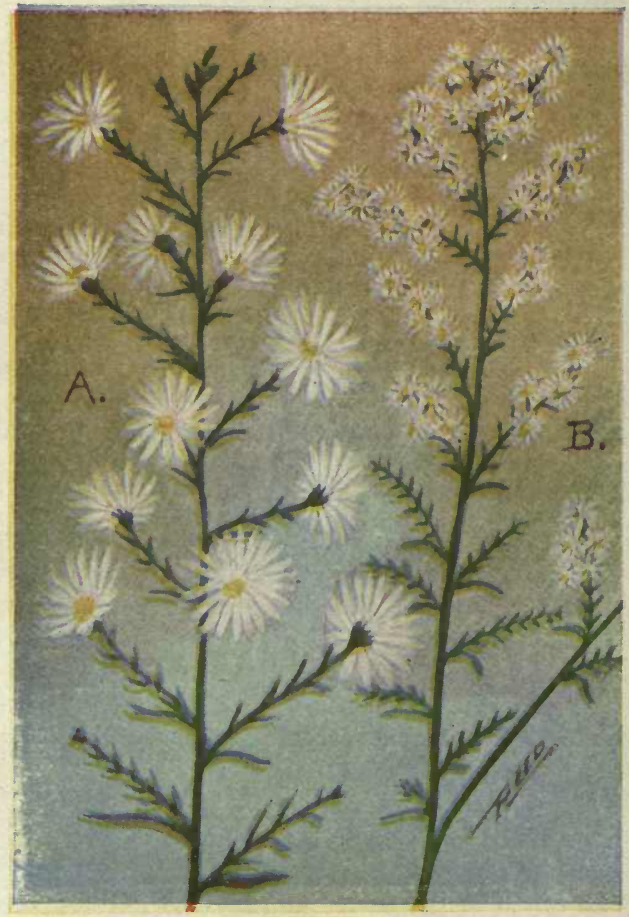

A. Heath Aster.

Aster ericoides.

B. Many-flowered Aster. Aster multiflorus. 
HEATH ASTER (Aster ericoides) is also a common white aster from Me. to Minn. and southwards. Its many flowers are but a little larger than those of the last. The plant grows 1 to 3 feet tall and has many branches, each having simple, many-flowered stems racemed along their outer ends. All the stems, even the flower peduncles, are set with tiny, healthlike, linear leaves. In our illustration, the apparently different size between the flowers of this and the last species is because the scale is different; the present one represents a single flowering stem, corresponding to one of the several shown in the other figure. All the asters are frequented by bees, this species is a special favorite with the honey bee and furnishes him with a large percentage of the nectar he secures during the waning days of his active year.

\section{MANY-FLOWERED ASTER (Aster multiflorus)} has, as its name would lead one to think, very many flowers, but they are small, averaging less than $1 / 2$ inch across. In fact most of the white-flowered species do have smaller flowers than the blue ones, but what they lack in size they more than make up in numbers. The stem is slender but very branching, making a bush-like plant. Each branch is terminated by short, many-flowered racemes. Our illustration shows but a tip of one of the very numerous branches. The leaves are tiny, light green and linear, smoothedged but rough to the touch, crowded along the branches to their tips. This is a common species from Mass. to Minn. and southwards, growing in dry places everywhere and blooming from Sept. to Nov. 


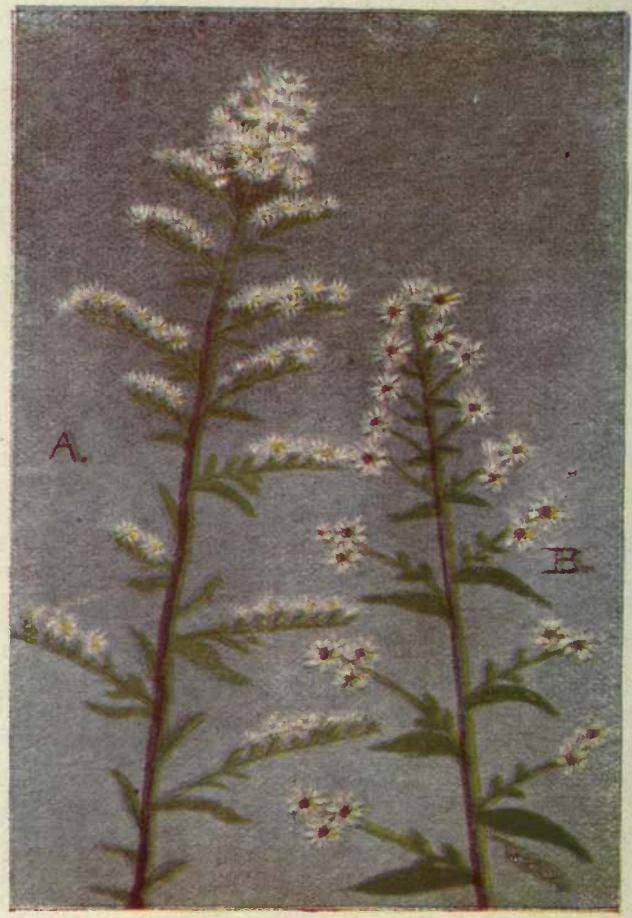

A. Aster vimineus.
B. Starved Aster.
Aster lateriflorus. 
SMALL WHITE ASTER (Aster vimineus) is still another of the tiny, white-flowered asters. It has a tall, branching stem from 2 to 5 feet high; the branches nearly all leave the main stalk in a horizontal position. The inflorescence is chiefly on one sidle of the flowering stems. This species can usually be identified by the reddish tinge to its stems. The leaves are linear or narrowly. lanceolate, the larger ones being obscurely serrate. The flowers are tiny, smaller than any of the preceding, but have from 15 to 25 narrow white rays. It grows in moist soil from Me. to Minn. and southwards.

STARVED ASTER (Aster lateriflorus) is a much branched, slightly hairy species, common in thickets and fields from N. S. to Ontario and southwards. The leaves are lanceolate and taper to a point at each end; they are rather rough and sharply serrate in the midlle. The plant has a "starved" appearance owing to the rather brownish colored disc florets; the ray florets are usually less in number than most of the other white species.

DAISY FLEABANE (Erigeron ramosus) is a common aster-like species found blooming in fields from June until October. The stem is rough-hairy and grows 1 or 2 feet tall. The leaves are also slightly hairy, smooth-edged, the upper ones lanceolate, the lower rather spatulate in shape tapering into slender petioles. The small, daisy-like flowers grow in a corymbed cluster at the top of the stem; they are about $1 / 2$ inch across, have quite a broad disc of tubular, yellowish fiorets and very numerous, narrow, ray flcrets; these rays range from 40 to 80 in number; at night they usually turn upwards so as to partly enfold the disc. 


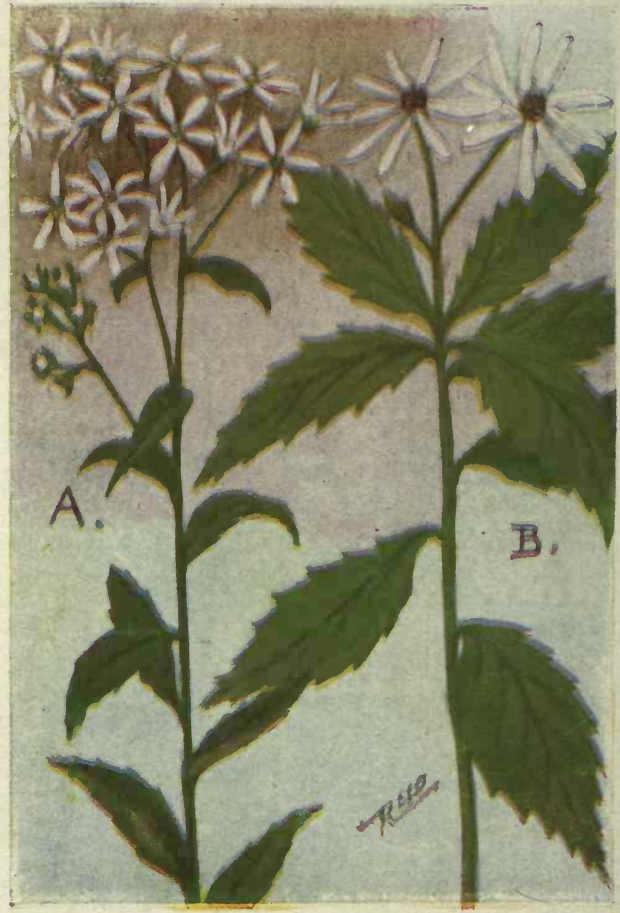

A. Flat-topped Wood Aster.

Aster umbellatus.

B. Sharp-leaved Wood Aster.

Aster acuminatus. 
Aster umbellatus is a common species of white aster found growing in moist woodland or thickets. It has smooth, leafy, branching stems from 2 to 6 feet tall. The leaves are lanceolate, pointed at each end and the lower ones are serrate.

The numerous flower heads are in compound flattopped corymbs; the center, or disc florets, are greenish-yellow and are surrounded by a few white rays, usually less than a dozen. It is a common species throughout the northern parts of the United States.

SHARP-LEAVED WOOD ASTER (Aster acuminatus) is a low-growing woodland aster with a simple, rather zig zag stem, quite hairy, growing from 1 to 3 feet in height. The leaves are quite large, sharplypointed, sharply toothed and short-stemmed. A few alternate along the lower portions of the stem and a number are so closely together as to appear whorled about the stem, just below the flowers. The flowers are few in number, on slender pedicels. They have few white rays and a rather brownish center, giving them a very unkempt appearance as compared to the tidiness of most of the asters; the rays are long, narrow, often wavy and give the flower a spread of from 1 to $1 \frac{1}{2}$ inches. It is quite a common species in cool rich woods from Labrador to Ontario and south to $\mathrm{Pa}$. and even farther in the mountains. It blooms during August and September.

Aster linariifolius is a peculiar, but not uncommon, aster found in dry soil in the northern parts of the United States. The stem is usually simple, with rough-margined, linear leaves and bears a single blossoms at the summit; the few rays are light violet or white and surround a brownish disk of tubular florets. 


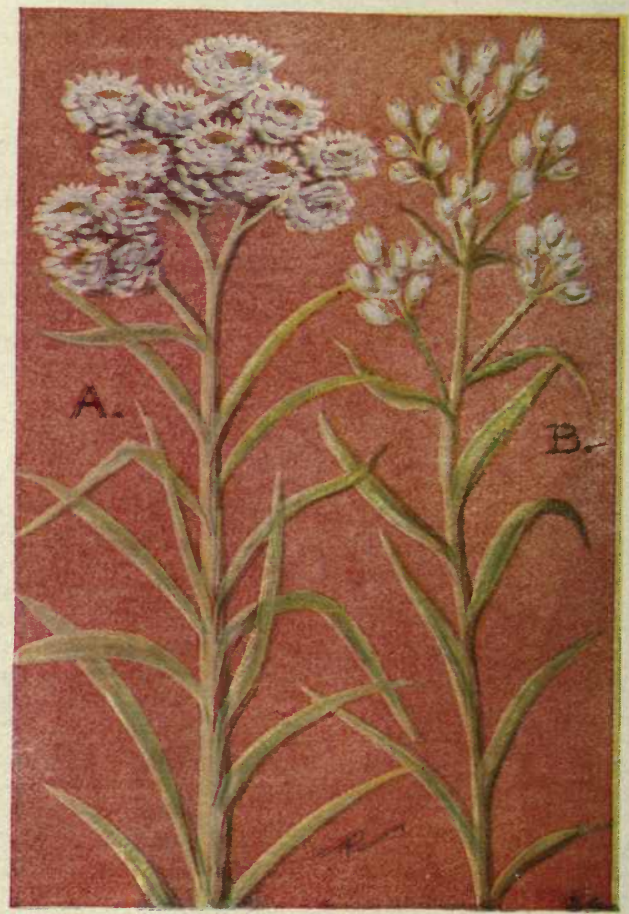

A. Pearly Everlasting.

Anaphalis margaritacea.

B. Everlasting.

Eugnaphalium decurrens. 


\section{Wild Flowers East of the Rockies}

PEARLY EVERLASTING (Anaphalis margaritacea) is the largest flowered and the prettiest of the everlastings. It is one of the very few flowers that will naturally preserve its cclor and shape upon drying. Because of this fact, these flowers are often preserved for vases and are used by florists for the making of wreaths. We frequently see them dyed green, blue, red, yellow, etc.

The stems are simple, quite stout, white-woolly, leafy and 6 to 30 inches in height. The leaves are long and narrow, have a smooth edge, are grayishgreen above and woolly below, and narrow into claspIng bases; they are closely set around the stem from the base to the flower cluster.

The flowers are in flat-topped clusters; each head is composed of many, pearly-white, dry, overlapping scales that surround brownish-yellow, tubular florets. Before they have expanded they look like large pearls but after opening they resemble, somewhat, miniature Water-Lilies. Staminate and pistillate flowers grow on different plants. When the flowers are opened, we usually see many varieties of small moths and butterflies about them, as well as small bees. These are the useful agents for cross-fertilization. This Everlasting is very common on dry hillsides, in woods or on recently cleared land. Its range extends from N. S. to Manitoba and southwards to S. C. and Mo. It is in full bloom from July until September.

SWEET EVERLASTING (Gnaphalium polycephalum) has a woolly stem and wavy, lanceolate, woolly leaves. The pearly flowerheads are oval in shape; they do not expand until after they have matured. It is common in pastures everywhere. 


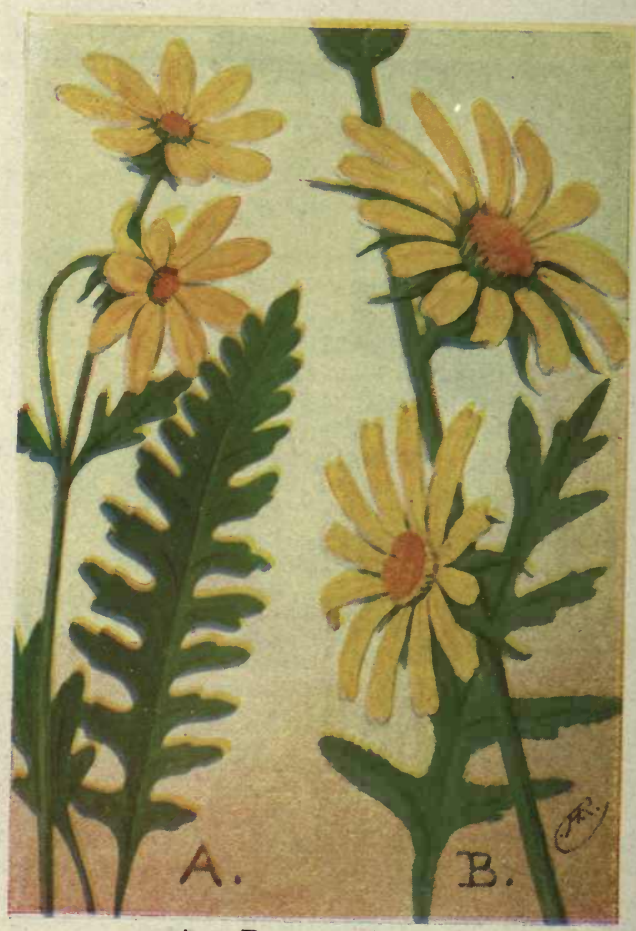

A. Prairie Dock.

Silphium terebinthinaceum.

B. Compass Plant.

Silphium laciniatum. 
ROSIN-WEED; COMPASS PLANT (Silphium laciniatum) is a large, showy-flowered plant found on the western prairies. It has a stout, rough, bristly stem that attains heights of from three to ten feet. The stem grows from a perennial root; it exudes copious, resinous juices. The large leaves are pinnately divided, each division being linear and cut-lobed; they are on long, broad petioles that spread into clasping bases.

The flower heads are very large, measuring from two to four inches across. They are sessile or exceedingly short-stemmed, seated along the upper portion of the stout stem. Their arrangement is quite similar to that of Chicory, the well known and common flower in the East. The bracts of the involucre are long and taper into spreading points, that spread nearly as wide as the ray florets; the central, tubular florets form a large, flat orange "button" and are surrounded by bright yellow, notched rays. The lower and root leaves are very large, ranging from one to three feet in length. They are disposed to present their edges north and south. Compass plant is found on prairies from Mich. to North Dakota and southwards; it blooms from July until September.

PRAIRIE DOCK (Silphium terbinthinaceum pinnatifidium), in spite of its cumbersome Latin name, is rather an attractive plant that also grows on prairies and the edges of copses. The smooth, slender st? $m$ ascends 3 to 10 feet high and bears a loose panic!e of large, yellow-rayed flower heads. The leaves rrostly come from the root and lower part of the stem they are slender-petioled and deeply pinnatifid. Found from O. to Minn, and southwards 


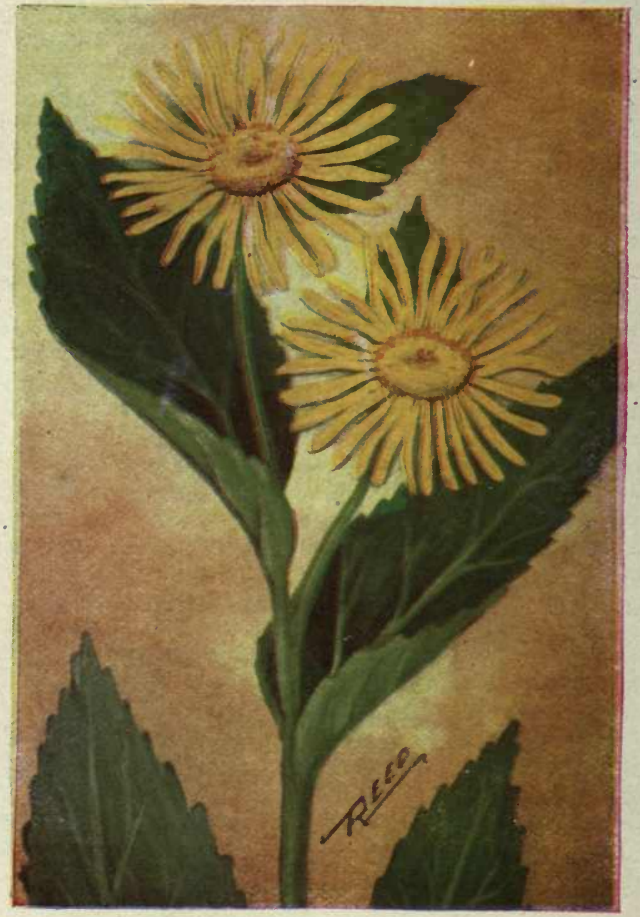

Elecampane.

Inula helenium. 


\section{ELECAMPANE (Inula Helenium) (EUROPEAN)}

is a tall, stout, beautiful member of the composite family that comes to us from the old world. It has become naturalized and is now common throughout the eastern half of the United States.

The stout, smooth, usually unbranched stalk grows from 2 to 6 feet in height and is leafy throughout. At the summit of the stem is a single, or sometimes two, large flower set cn a peduncle from the angle of the upper leaf. A smaller, flat, bract-like leaf appear just below the flower involucre. The head measures two or three inches across and has a broad dise of tubular, yellow florets, these turning tan color as they age. The yellow rays are numerous, but very narrow, usually set at different angles and with some vacant places so that the flower has a rather disheveled appearance.

The upper leaves usually clasp the plant stem, while the lower ones are on petioles. They are broad, thick-textured, toothed and pointed; the large, whitish veins show very prominently; the upper surface of the leaf is rough, yellowish-green, while the lower is lighter and woolly. They alternate quite closely along the stem.

The leaves were formerly used by industrious country housewives for the concoction of various home remedies and doubtless proved effective. The roots yield a mucilaginous juice that was supposed to have healing and antiseptic properties. Bees, butterflies and small moths are usually seen about the beautiful flower heads, and are the chief agents for cross-fertilization. 


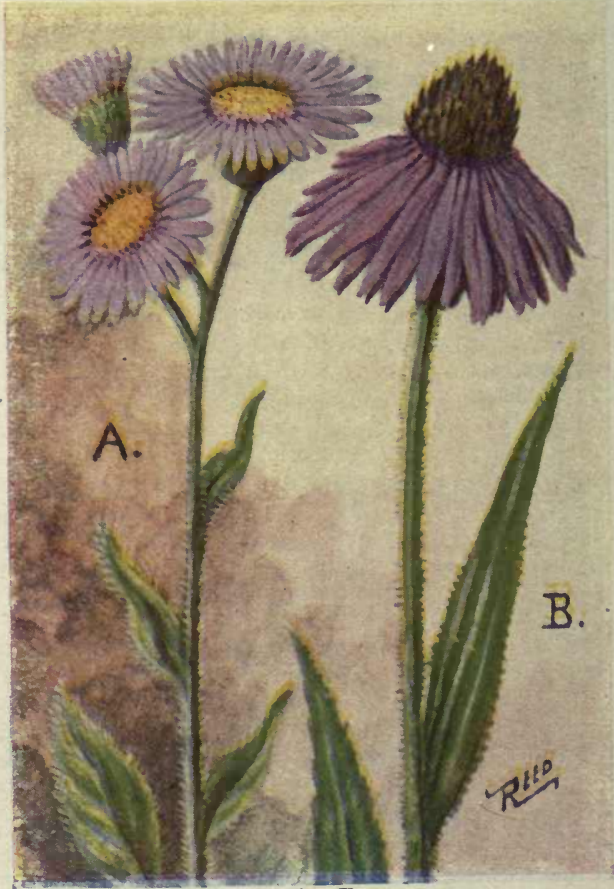

A. Robin's Plantain.

Erigeron pulchellus.

B. Purple Cone Flower.

Brauneria purpurea. 
ROBIN'S PLANTAIN (Erigeron pulchellus) is one of the earliest members of the composite family to bloom. In fact it is often known as the "Blue Spring Daisy," a name which is very appropriate for it, much more so than the one it commonly bears. The very fuzzy, light green, juicy stalk attains heights of from 10 to 24 inches. Nicst of the leaves are in a dense rosette at the base of the stalk they are spatulate in shape, indistinctly toothed and hairy throughout. The few stem leaves are small, hairy and clasping at their bases. From one to nine flowers, an inch, or slightly more, broad are grouped at the top of the stem. They are handsome blossoms, resembling asters, but the yellowish centers of tubular florets are broader and flatter; the lilac or violet rays are very numerous and are arranged quite evenly around the central disc.

Robin's Plantain is a perennial with creeping rootstalks and will be found year after year in the same localities. It is often communistic and found growing in quite large colonies; it may also be met with singly. It is common everywhere, most abundant in slightly moist soil, from Me. to Minn. and southwards, blooming in May and June.

PURPLE CONE FLOWER (Brauneria purpurea) is a showy western species bearing a single, large flower head with a conical center of purple disc florets and surrounded by many, large, notched, magenta rays. The stiff, hairy stem rises 2 to 3 feet high. The leaves, also stiff-hairy, alternate along it; the upper ones are toothless and seated on the stem, while the lower ones are sharply toothed; they are five-ribbed and deep green in color. Rich soil, N. Y to Mich. and southwards. 


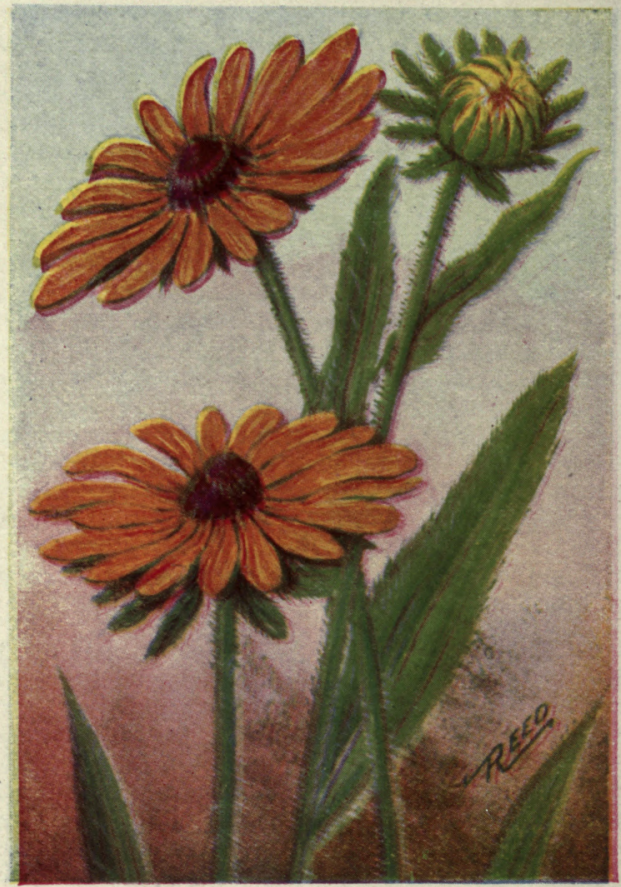

Black-eyed Susan; Cone Flower. Rudbeckia hirta. 


\section{BLACK-EYED SUSAN; YELLOW DAISY; CONE} FLOWER (Rudbeckia hirta) is a beautiful, largeflowered, tough-stemmed species that is commonly found in dry fields and pastures throughout the East, although it is, by nativity, a western species.

The stem is hairy, rough, very tough and grows from 1 to 3 feet in height; usually it is simple but sometimes tufted, that is two or more stems may proceed from a single root. Single, large flowers are borne at the summit of each stem.

The involucre is composed of two rows of leaf-like bracts that spread as the flower opens, the outer ones extending almost as widely as the rays. The conical, dark purple center is composed of long, tubular florets that ripen in successive circles about the cone, making a fringe of yellow pollen on its surface. The orange-yellow rays are neutral, with neither stamens nor pistils. They have their uses, however, for they present a flaming advertisement to all passing bees and butterflies, of the stores of nectar and pollen to be reaped from the florets at the center. The tubes are long and the nectar is seated at the bottom, so it is only insects with long, slender tongues that are enabled to taste of the sweets.

The leaves, scattered alternately along the stem, are also stiff and hairy; they have three prominent ribs. The upper ones are lanceolate and seated on the stem, the lower ones are broader towards the tip, rather spatulate-shaped. The plant stem is so rigid and tough that it is difficult to pick the flowers without pulling up the entire stem. This should be carefully avoided, for the roots are perennial and plants will spring up year after year if they are undisturbed. 


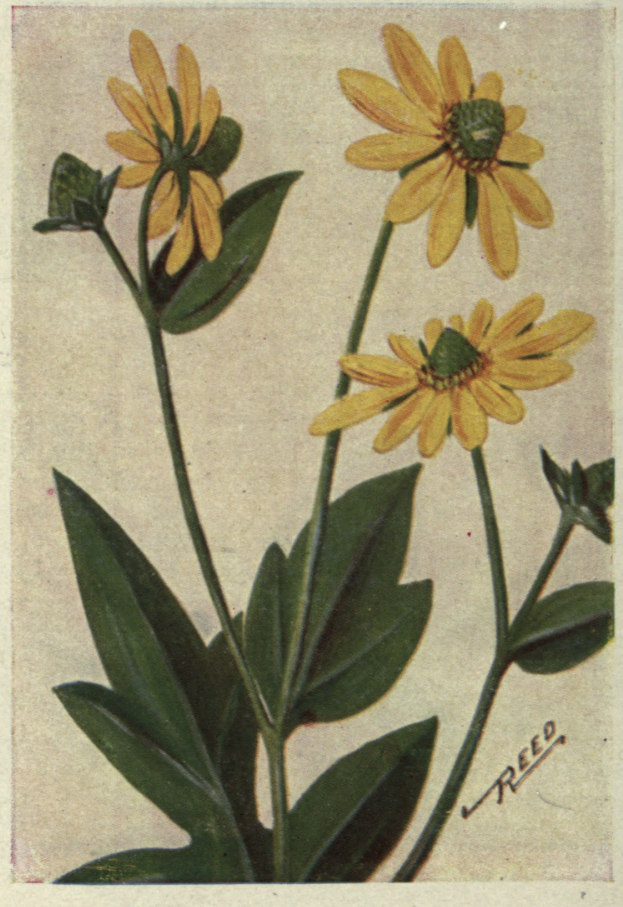

Tall Cone Flower.

Rudbeckia laciniata. 
TALL CONE-FLOWER (Rudbeckia laciniata) is a tall, lanky member of this genus, with an entirely different temperament from that of the Blackeyed Suson. No hot, sandy or dusty fields for this, but the cool depths of moist thickets. As usual with vegetation in moist, rich soil, its growth is luxuriant. The smooth, branching stem ascends to heights of 3 to 10 feet and is leafy throughout. Ordinarily, the plant does not grow more than five feet in height; those that exceed this height might be termed giants of the species. The lower leaves are very large, are on long petioles and are cleft into five or seven divisions; the lower and middle stem leaves are usually three-parted while the upper ones, or at least, the ones nearest the flowers are small and elliptical.

Several large flower heads terminate the branches; they measure from 2 to 4 inches across. The central disc is, at first, hemispherical and green but finally becomes elongated and brownish. The rays number six to 12 and are bright yellow in color. This species blooms from July until Sept. and is found from Me. to Manitoba and southwards.

Rudbeckia triloba is a hairy biennial with slender, spreading branches, at the ends of which are numerous, comparatively small, but showy, flower heads. The central disc is hemispherical, composed of brownish-purple florets. The rays are golden-yellow, brightest near the disc. The leaves are bright green, thin, rough, the upper ones being lance-shaped and the lower one three-lobed; all are rather coarsely toothed. Common in rich soil from N. J. to Minn. and southwards. 


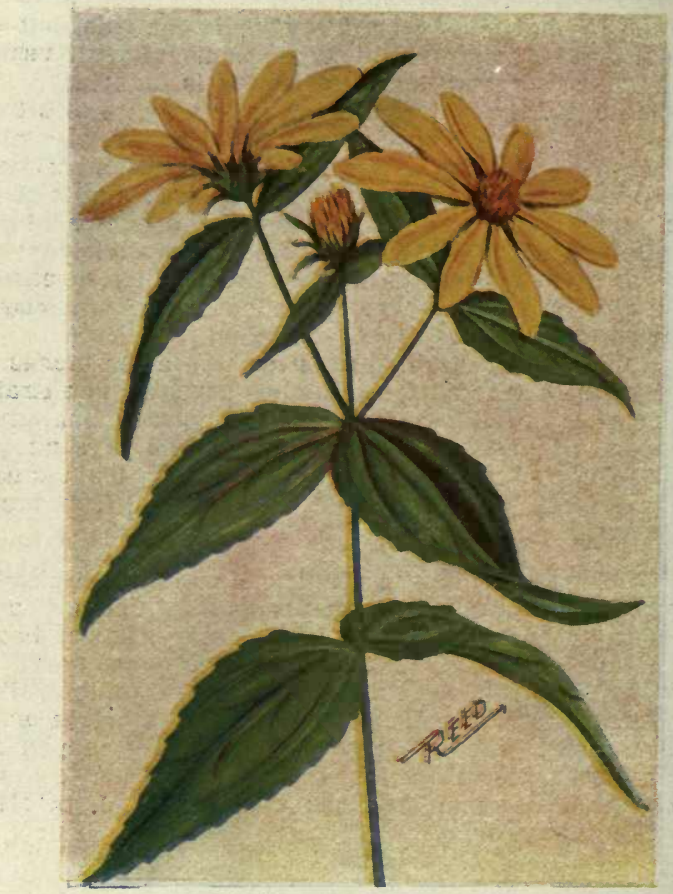

\section{Ten-petalled Sunflower.} Helianthus decapetalus. 
TEN-PETALLED SUNFLOWER (Helianthus decapetalous.) This is a slender stemmed, graceful, showy-flowered Sunflower, common in damp woods and on the borders of thickets, from Me., Quebec and Minn. southwards. The branching stem grows from 2 to 5 feet tall; it is slightly hairy-rough on the upper portions but smooth below. The leaves are thin, rather rough-broad lance-shaped, short-stemmed and grow oppositely on the stem; they are all sharply saw-toothed. The showy flowers, growing on slender peduncles from the ends of the branches, are 2 to 3 inches across. Though often with ten rays, they just as frequently have any number from 8 to 15 .

COMMON SUNFLOWER (Helianthus annuus) is the common garden sunflower that often has such enormous heads. The normal, wild plant is common from Minn. to Texas and westward. The flower heads range from three to six inches in diameter; it is only the cutlivated variety, produced from this, that has the mammoth heads we often see. It has been introduced into most civilized countries and furnishes many staple articles of commerce. It probably reaches its greatest development in point of size in Russia, the seeds from plants grown in that country being more than double in size of any produced in the United States.

In its wild state the plant only grows from three to six feet tall. Its name is due, not only to its sunlike face, but also to the fact that the flowers usually face the sun, turning their heads slowly so as to follow it around the horizon. Their period of bloom is from July until Sept.. This species may readily be recognized by the large, alternately, three-ribbed, rough, toothed leaves. 


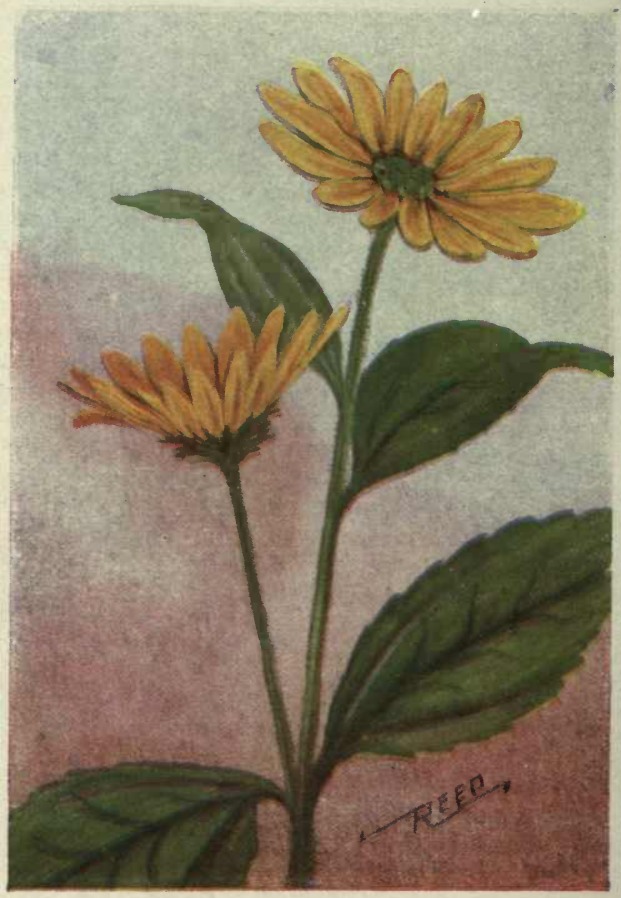

Jerusalem Artichoke.

Helianthus tuberosus. 


\section{JERUSALEM ARTICHOKE (Helianthus tubero-} sus) is, like the Common Sunflower, a valuable species, and one that is often cultivated because of its edible roots, these being tender and of good fiavor; they are eaten raw or cooked. Their value as articles of food was first discovered by Indians and by them imparted to our early colonists. The name Jerusalem, in connection with this plant, is a corruption from the name applied to the species by Italians, (Girasole Articocco), meaning sunflower artichoke.

It is a handsome plant, the stout, leafy, hairy stalk growing from 3 to 12 feet tall and being topped with several large showy flowers. The large, three-veined leaves are hairy and have toothed margins. They are chiefly set oppositely on the stem, although some of the upper ones may alternate. The several flower heads are large, measuring up to three inches across. The central florets are greenish yellow and are surrounded by from 12 to 24 long, golden-yellow rays.

This species is often also known as the Canada Potato and the Earth Apple. Its range extends from southern Canada southwards nearly to the Gulf.

TALL or GIANT SUNFLOWER (Helianthus giganteus) is a very tall species with a rough, ruddy stem from 2 to 10 feet tall, growing from perennial creeping, tuberous roots. The leaves are rather coarse, rough, bright green, toothed, nearly stemless and usually alternating along the stem. The stem branches at the summit and bears several large flower heads from 2 to 3 inches across. The yellowishgreen disc is surrounded by from 10 to 20 neutral, golden rays. The Tall Sunflower is common in swamps and on the borders of wet woods from New England to Minn. and southwards. 


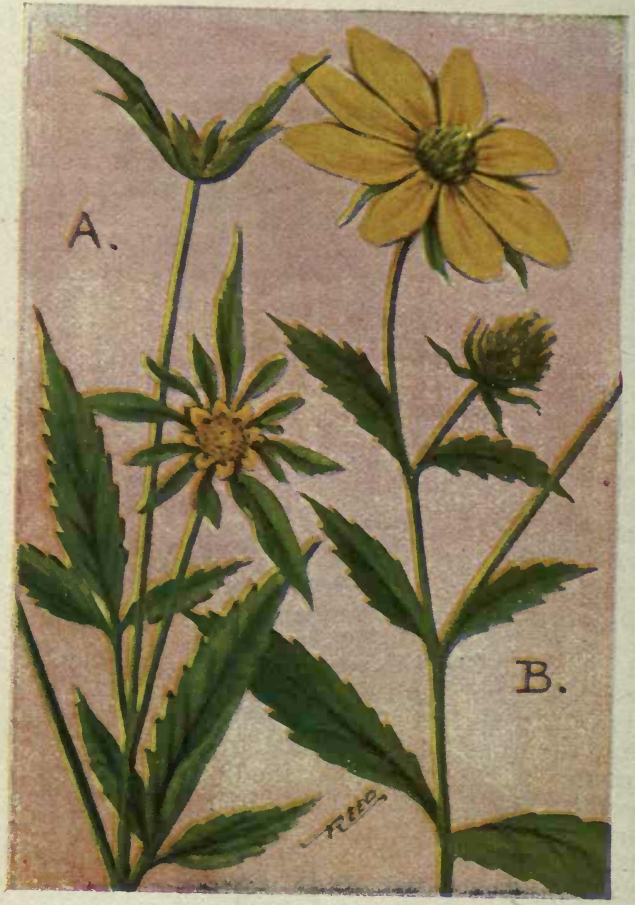

A. Beggar Ticks.

Bidens frondosa.

B. Large Bur-Marigold. Bidens laevis. 
BEGGAR-TICKS; STICK-TIGHT (Bidens frondosa) is a plant familiar, to their sorrow, to all who roam the woods and fields durirg; Fall. Who has not had the pleasant task of sitting down and, one by one, removing the little two-hooked, black seeds that hang so closely to clothing. These little hooked seedpods are not designed for the adornment of the plant, nor for the purpose of annoying human beings, but serve a very important purpose, just like the plumed seeds of the milkweed, but they travel in a different manner. Of course they were originally designed to be carried from place to place on the hairy coats of our wild animals but man often serves their purpose even better than beasts.

Beggar-ticks, in appearance, is an uninteresting weed common everywhere in moist ground or along roadsides. The stem is yery branching and is from 1 to 8 feet tall. The leaves are compounded of three to five, sharply toothed, lance-shaped leaflets. The flower heads are composed of tubular brownish-yellow florets, sometimes with no surrounding rays and again with a few, tiny, short ones.

\section{LARGER BUR-MARIGOLD; BROOK SUNFLOW-} ER (Bidens laevis) is a very attractive species while it is in flower, but later, after the little seeds have formed, it has the same disagreeable traits common to all the members of the genus; the seeds have the same two little teeth (bidens) and stick just as closely as those of their more homely relatives. The flowers of this species are 1 to 2 in. across, having 8 or 10 large, yellow, neutral rays surrounding the dullcolored disc florets. The stem is slender and branching, the leaves lance-shaped and toothed. Common in swamps and along brooks. 


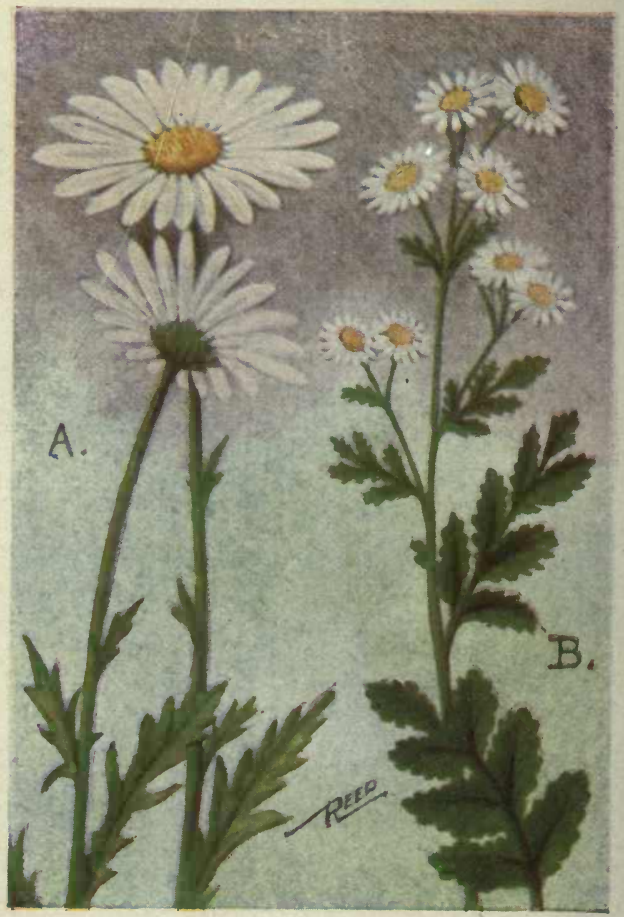

A. Ox-eye Daisy; White Daisy. Chrysanthemum leucanthemum. B. Feverfew. Chrysanthemum parthenium. 
COMMON WHITE DAISY; OX-EYE DAISY (Chrysanthemum leucanthemum) (EUROPEAN) is a naturalized, floral citizen. It is so common and has become so wide-spread that it is even better known than most of our common native flowers. It is a very beautiful species in the eyes of all not engaged in pursuits agricultural, but to the farmer it is a pest that must be exterminated if he would make hay. It grows in such profusion and multiplies so rapidly that it often forms a snow-white, floral carpet over whole fields. They furnish beautiful bouquets for the home and much amusement for the children. I wonder how many of the lassies, who read these lines, fail to remember the old ditty:- "Rich man, poor man, etc." and the shorter one supposed to conclusively prove or disprove the affection of someone.

This daisy needs no description. We have two very similar kinds differing in the shape of the leaves one being more pinnatifid than the other. The one shown on the opposite page is the most common, a variety of Leucanthemum called (pinnatifidum). The other variety has the ends of the leaves rounded and finely toothed but not cut or slashed.

\section{FEVERFEW (Chrysanthemum Parthenium) (EURO.} PEAN) is found in some places in the East as an escape from gardens. The stem grows from 1 to 2 feet tall and is quite branching. The flowers are grouped in clusters; they are much smaller than those of the last species and have a comparatively broader disc of yellow florets. The leaves are broad, deeply pinnatifid and each division further toothed or cut. It is locally naturalized from Mass to N. J. and westwards. It blooms from June until Sept., the same as does the last species. 


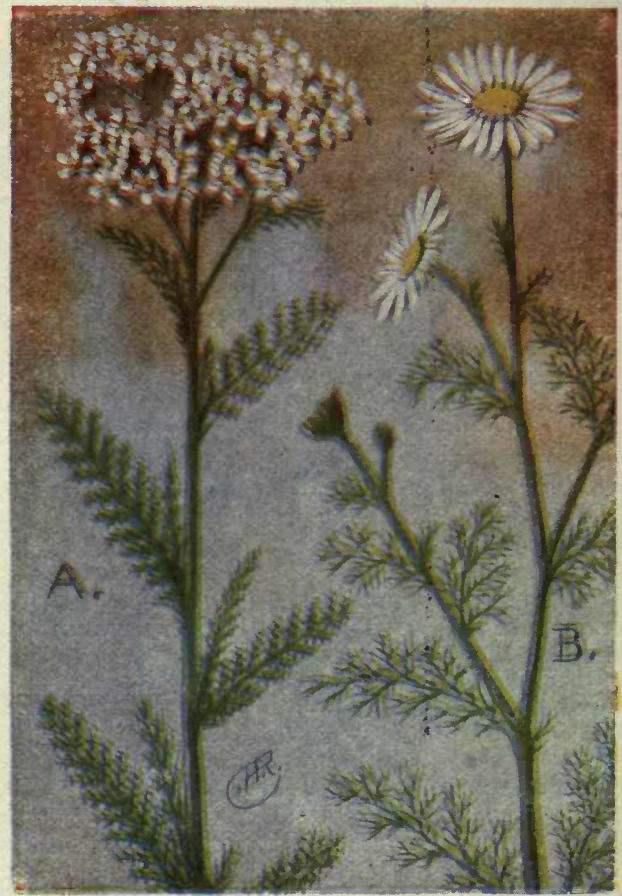

A. Yarrow.

Achillea millefolium.

B. Mayweed; Chamomile. Anthemis cotula. 
YARROW; MILFOIL (Achillea Millefolium) is one of the most common of our wayside weeds. Its generic name is applied because the mighty Achilles formerly used an old World yarrow for healing the wounds of his soldiers. The leaves and their juices are still used in this and other countries in medicinal remedies and for their healing properties.

The stem is stout, gray-green usually simple, or forking near the top. The leaves, alternating along and clasping the stem, are soft and feathery,-deeply and finely bipinnatifid.

The flowers grow in very compact, flat-topped clusters at the top of the stem. Each flower head has a center of short, tubular, yellowish florets that turn brown or grayish as they grow old; they are surrounded by from four to six round, white rays. In some localities these ray fiorets, that, by the way, are pistillate, vary in color through pink to a deep crimson. This latter color is most apt to occur near the seacoast. I have met with it most frequently on Cape Cod.

Yarrow is a very hardy plant; we may find it thriving beside roads where the dust has killed nearly every other living thing. Its leaves have a strong, not unpleasant, aromatic odor.

MAYWEED; CHAMOMILE (Anthemis Cotula) (EUROPEAN) is also a common weed found by the wayside in company with the last species. The stem is very branchy, 8 to 20 inches high. The leaves are very finely divided. The strong, unpleasant odor of the foliage will at once correct the impression that it may be a daisy. The flowers are very similar to those of the common White Daisy except for their smaller size. Very common about dwellings and along roadsides everywhere. 


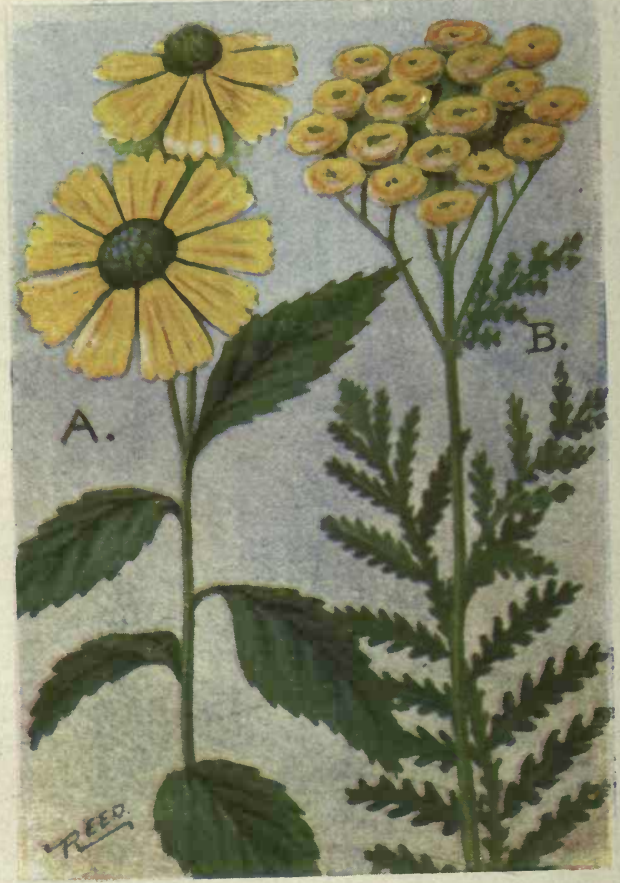

A. Sneezeweed. Helenium autumnale.

B. Tansy. Tanacetum vulgare. 
SNEEZEWEED (Helenium autumnale) is a beautiful, rather odd, plant that brightens meadows and swamps during August and Sept. The stem is rather stout, smooth and branching; it ascends from 2 to 6 feet. Alternating along the stem, are numerous ovate, pointed, sharply-toothed, bright green leaves,short-stemmed and strongly veined.

It is the blossoms that attract our attention for, besides being very handsome, they are unusual in form. The hemispherical center is composed of closely parked tubular florets and is surrounded by a numkif: of broad, toothed, golden-yellow rays; the heads hive an expanse of 1 to 2 inches. Both the tubular and the yellow, pistillate rays are fertile. The flowers are frequented by numbers of various kinds of bees and many small butterflies. The disc florets secrete an abundance of nectar in their tubes.

Although this plant has little odor, the foliage is very bitter and cattle soon learn to avoid the leaves. Sneezeweed or "Swamp Sunflower" is common along brooks, river banks and in wet ground generally, from the Atlantic to the Pacific.

\section{TANSY; BITTER BUTTONS (Tanacetum vulgare)} (EUROPEAN) is one of those lusty, foreign plants that take so kindly to our soil and climate that they try to over-run the country. This species is abundant everywhere about houses and along roads, from the Atlantic to the Rocky Mountains, and is gradually extending its range towards the Pacific.

The foliage is very bitter and is the foundation of many an old fashioned remedy. The flowers grow in flat-topped clusters and are composed of round discs, or "buttons," of tubular florets only. It is a species not to be mistaken; it has an appearance, an odor and a taste of its own. It blooms from July until the end of September. 


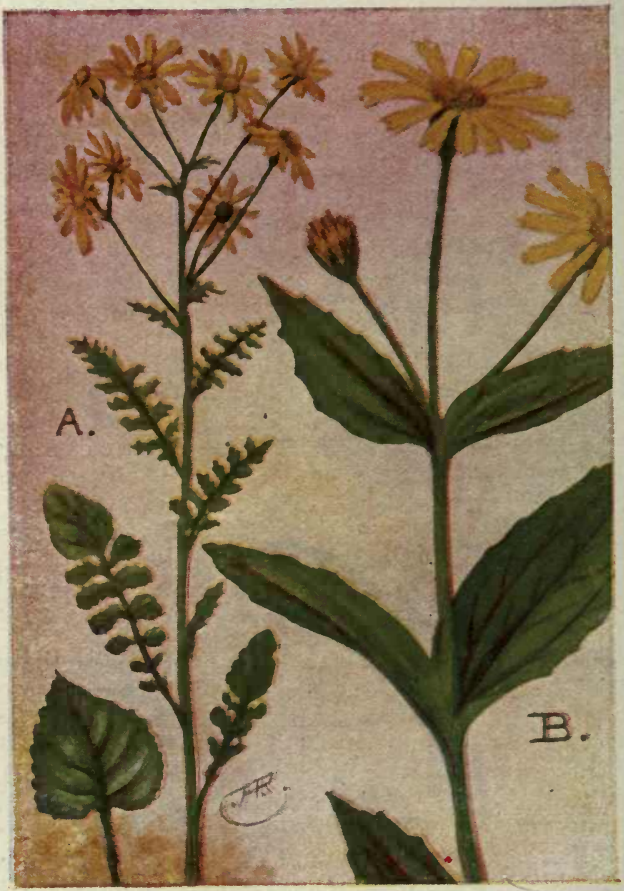

A. Golden Ragwort. Senecio aureus. B. ArNica. Arnica mollis. 
GOLDEN RAGWORT (Senecio aureus).. As the blue asters have a similar representative, early in the year, in the form of Robin's Plantain, so the yellow asters or sunflowers have theirs, too, in this species. In latter March and early April, Ragwort shows simply a tuft of stemmed, heart-shaped leaves, resembling those of violets. A little later a stem ascends from the perennial root; a slender, tough, angular, twisting stem that finally reaches heights of 1 to 3 feet; a single stem, or two or three, may rise from the same root. During May and June, they carry at their summit a loose cluster of bright, orange-yellow flowers. These are deeper colored than most of the Fall asters, in fact they are almost the same shade as the rays of the common Cone Flower. Each flower is composed of but 8 to 12 narrow, orange-yellow rays, surrounding a central cluster of tubular florets of a brownish-orange color.

The stem leaves are chiefly sessile; they are oblong in shape but deeply cut or pinnatifid, the terminal section being less so than the basal half. Ragwort grows most abundantly and most luxuriantly in swamps or moist ground, but is also found in dry places or stony pastures. Its range extends from Newfoundland to Wisconsin and southwards to Va. and Mo.

ARNICA (Arnica mollis) is a northern plant with large, delicate, pure yellow, daisy-like flowers. Its slightly hairy stem grows from 1 to 2 feet tall. The basal leaves are long-petioled but the stem ones are sessile and opposite, shallow-toothed. At the summit are one to nine flower heads on slender peduncles. About the central disc are 10 to 14 yellow rays, each with three notches in their ends. Found in Canada and the mountains of northern U. S. 


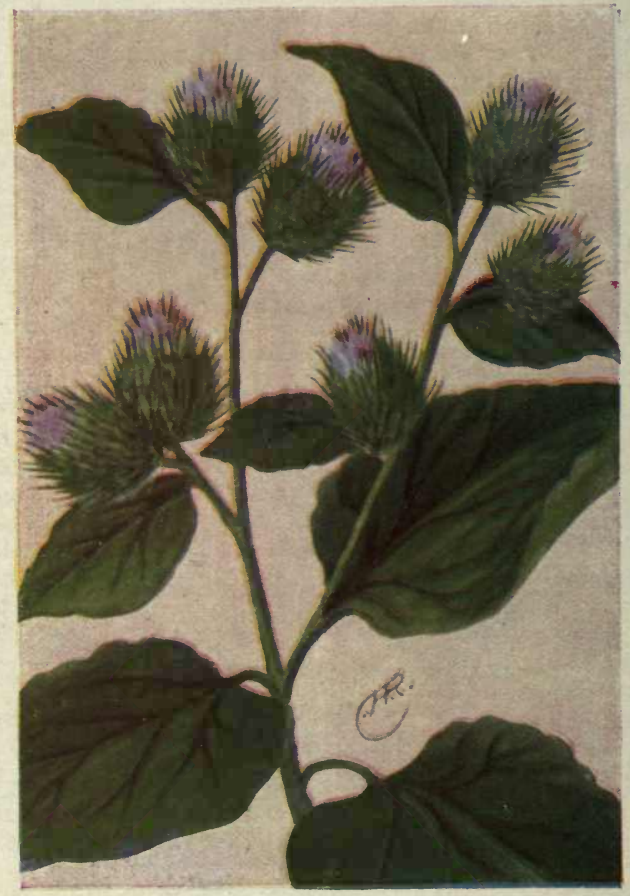

\section{BURDOCK.}

Arctium minus. 
BURDOCK (Arctium minus) (EUROPEAN) is a very common plant on waste ground, along roadsides and the edges of woods. The plant is often four feet or more high. The lower leaves are very large, often more than a foot in length, heart-shaped, deep green and finely veined above, greyish beneath because of the fine wool that covers the under surfaces. The upper leaves are smaller, more ovate in form and less densely woolly on the undersides. The flowerheads grow in clusters at the ends of the branches. The involucre is almost spherical,-composed of numerous bracts, each terminating in a sharp, hooked point. Tubular florets, only, are seated within this involucre; they are purple and white in color, and secrete an abundance of nectar, on which account they are frequented by honey bees.

We have seen how the Milkweed attaches to each of its seeds, a little parachute so it may fly away on the winds and found new colonies at a distance from the parent plants. We have also seen how the Beggar-tick and members of the Genus (Bidens) disperse their seeds by attaching them to the hair of animals or the clothing of man. The present species adopts the policy of the Beggar-ticks, but instead of single seeds, it attaches the whole bur-like head by means of its numerous little hooks. They cling tenaciously to everything they touch; doubtless most of my read. ers recall massing these burs together to make castles, funny men, animals, etc.

We have two species of this plant, - the present, and one slightly larger and with coarser leaves, (A. Lappa). Both of them are immigrants from across the water. 


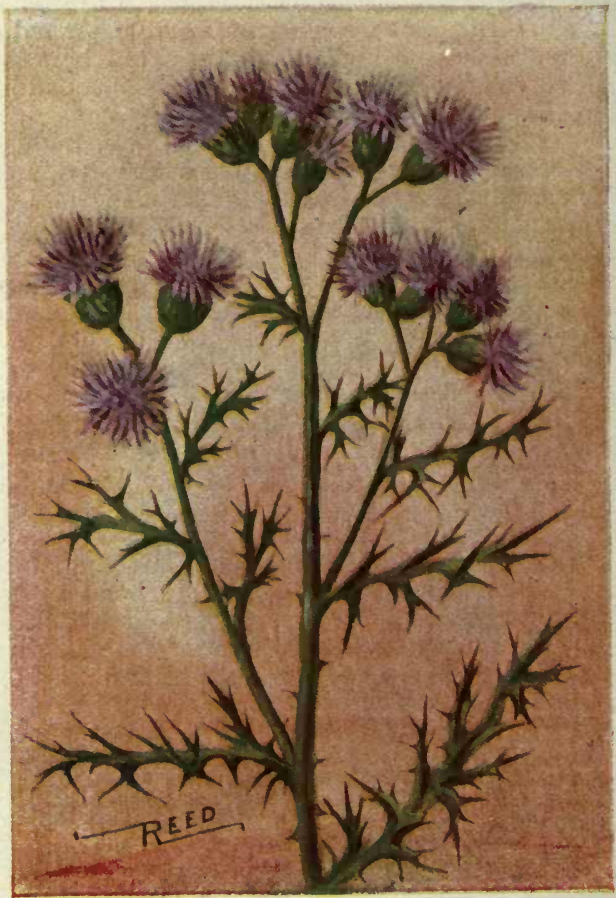

Canada Thistle.

Cirsium arvense. 
CANADA THISTLE (Cirsium arvense) (EUROPEAN) is a small flowered, perennial species that has strayed across the ocean and became a pernicious weed. Individual plants are not themselves any more of a pest than are our native thistles but they have a dangerous, latent or potential power, in that they are far more prolific than our native species, due perhaps more to the number of the flowering heads than to any physical qualities of the plant.

The stem is rather slender, branching and grows from 1 to 3 feet in height. It grows from a perennial, creeping rootstalk that is, as farmers have discovered, very difficult to eradicate from the soil. It grows in extensive colonies and, unless strenuous efforts are made to destroy them, they very soon take possession of a field to the exclusion of almost everything else.

The leaves, that grow alternately and closely together on the stem, are long, lance-shaped, deeply cut into sharply-prickled lobes, Numerous flower heads, about one inch across, terminate the branches. When in full bloom, the florets vary in color from rose-purple to white; the involucre is almost globular and covered with over-lapping bracts, each with a tiny, sharp, out-turned point.

All the thistles yield an abundance of nectar and are frequented by bees and butterflies, by one of the latter so persistently that it has been named the Thistle Butterfly or Painted Lady (Pyrameis cardui); in fact this butterfly usually begins its career, as a caterpillar, on the thistle and lives chiefly upon its nectar and pollen through life. 


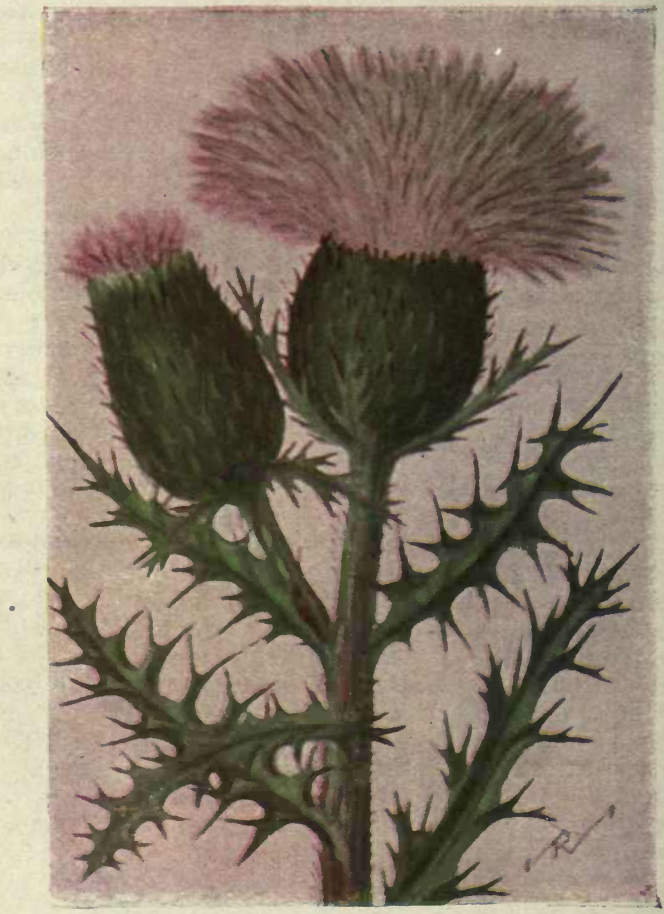

Pasture Thistle.

Cirsium pumilum, 
PASTURE THISTLE (Cirsium pumilum) is the thistle that we most often see in fields and pastures. It is one of the largest of the genus, its heads often measuring three inches across. The stem is stout and simple, and grows from 1 to 3 feet high; it is hairy and angular in section and grows from a biennial rootstalk.

The flower heads are very large, two to three and one-half inches across and usually solitary, although frequently two heads grow on the same stalk. The leaves are lance-shaped, green, clasping, rather hairy, pinnatifid and armed with short, stout prickles. Just below the flowers are several small bract-like leaves, also armed with sharp prickles. All this armor tends to discourage pilfering insects from crawling up the stem; should they persist and reach the large involucre, which is also armed, they will find that, in addition, it is slightly sticky, and presents an impenetrable barrier to their upward progress. This species is common from Me. to Del. and Pa. It blooms from July until Sept.

COMMON or BULL THISTLE (Cirsium lanceolatum), although an introduced species has a larger range than the last. It is common in fields and pastures and along roadsides from Newfoundland to Ga. and west to Nebr. Its heads are only slightly smaller than those of the preceding; usually but one is found on a plant. The stout stem grows from 2 to 4 feet high. The leaves are rough and bristly above and woolly underneath.

Although thistles may be foes to those following agricultural callings, they are staunch friends of birds and insects (except crawling ones). The plant fibres and down from the mature heads forms the principal part in the composition of nests of the Goldfinch. 


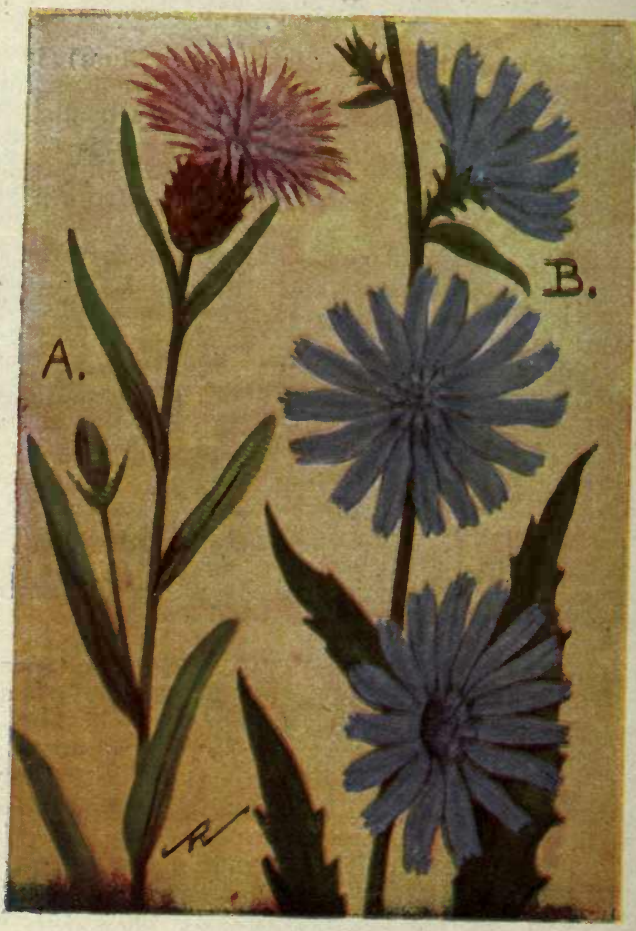

A. Star Thistle.

Centaurea Scabiosa. B. Chicory; Succory. Cichorium intybus. 
STAR THISTLE (Centaurea nigra, var. radiata). This is a slender-stemmed plant with a small, thistle-like head but with none of the other characteristics of the true thistles.

The slender stem branches slightly and rises to heights of 1 to 2 feet, each branch bearing a solitary flower head at the end. The flower head has a round involucre of tawny, or dark brown, dry bracts; the florets are all tubular and rose-purple, the outer ones being rather larger and spreading horizontally. The whole head has a loose tousled appearance. Rather small, oblanceolate leaves alternate along the stem, from the base to the flower heads.

This species, which is introduced from Europe, grows in waste places and along roadsides from $\mathrm{N}$. $\mathrm{S}$. to Ontario and south to $\mathrm{N}$. J. and $\mathrm{Pa}$. It may be found in bloom from July until Sept.

CHICORY; SUCCORY (Cichorium intybus) (EUROPEAN) has become thoroughly naturalized and is common in the eastern half of the United States, especially so near the coast. It is a perennial so there is little danger of its losing ground in any locality in which it becomes established.

The stem is stiff, tough and angular in cross-section; it attains heights of from 1 to 3 feet. It is often quite branching but the branches spring out abruptly so that the effect is not very graceful. The leaves are long-lanceolate, dark gray-green and coarsely toothed. The flowers are very beautiful,-a violet-blue, approaching a pure blue in color. There are at least two ranks of strap-shaped rays, the inner ones much shorter, all toothed at the ends. Succory blooms in dry situations from July until Oct. 


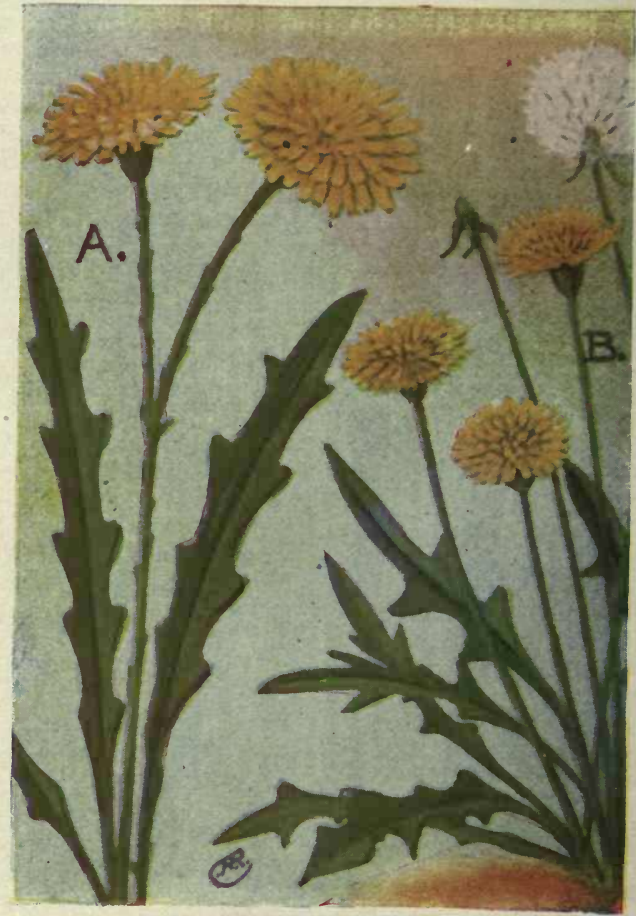

A. Fall Dandelion.

Leontodon autumnalis.

B. Dwarf Dandelion; Cynthia.

Krigia virginica. 
FALL DANDELION (Leontodon autumnalis) (EUROPEAN) is a small dandelion, naturalized from Europe and common in the Eastern States during Fall, or from the latter part of July. The leaves, tufted at the base of the flower scape, are long and narrow and have blunt teeth. The flower scape is long and slender and usually forks near the summit, bearing two or three flower heads, rarely only one; the scape attains heights of 7 to 18 inches. The upper parts of the stem are covered with minute, scaly bracts set at intervals of perhaps every half inch. The flower stalk is not hollow like that of the common dandelion, but is solid. The flower heads are large and showy, composed of numerous, golden-yellow, toothed, strap-shaped rays, set in a small involucre, scarcely imbricated but with several bractlets at the base. It grows in fields and along roadsides and is quite common from Newfoundland to Mich. and south to Pa.

DWARF DANDELION; CYNTHIA (Krigia virginica) is a tiny little plant as compared to the common dandelion. The leaves are all basal on rather long petioles; they are coarsely and sharply, or lacinately, toothed. Numerous unbranching, slender flower scapes rise from these tufts of basal leaves, each bearing at the summit a little golden-rayed flower resembling a miniature dandelion. When the flower heads have matured, the scape lengthens and fluffy parachutes, each attached to tiny seed, form into filmy globes that takes the places of the flowers until the winds bear them away to new fields.

Cynthia is a very common native species and is found blooming from April until July in dry fields, open woods or sandy soil, from southern Canada to the Gulf. 


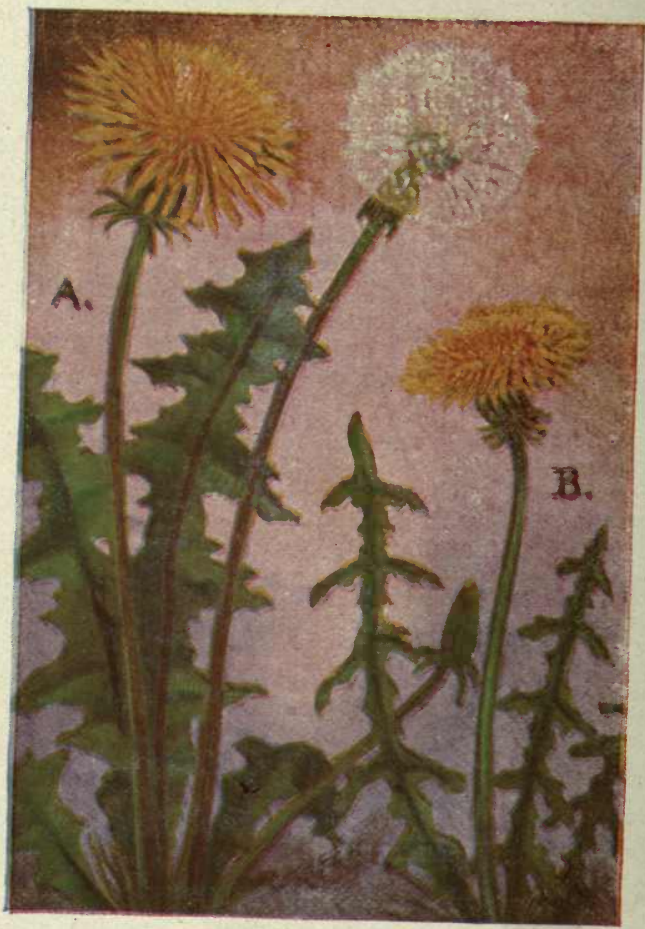

A. Common Dandelion. Taraxacum officinale. B. Red-seeded Dandelion. Taraxicum erythrospermum. 
COMMON DANDELION (Taraxacum officinale) al. though an immigrant to our land, has extended its range from the Atlantic to the Pacific, and is as well, or better, known as any other wild flower that we have. As everyone knows, its green, jagged leaves form a staple article of food and can be purchased in markets in Spring at so much per peck. This species, with its large, flat rosette of leaves and bright sunny flowers needs no description; it is well shown on the accompanying plate. All parts contain a bitter milky juice that exudes freely whenever the plant is broken. It is most interesting to children when the flowers have gone to seed and are replaced by the round fluffy heads. Many childish games and fancies depend upon the number of seeds left in the "puff ball" after a good strong "blow." The stems, slit at the ends, make little horns and are also used for drinking purposes and for "blowing soap bubbles."

Those who try to keep a lawn in condition, regard the dandelion as a great pest. Its persistence is shown, when we may find the flowers sunnily smiling at us, the day after the grass has been cut as closely as possible with a mower. The dandelion blooms most abundantly during the Spring months but may also be found during every other month, even in Winter. The name dandelion, of course, refers to the jagged edge of the leaves.

RED-SEEDED DANDELION (Taraxacum erythrospermum) is a smaller species, also European, with more deeply cut leaves, (pinnatifid), and with reddishbrown seeds, whereas those of the preceding species are usually olive-green. Common in dry fields from Me. to Pa. and westward to the Mississippi. 


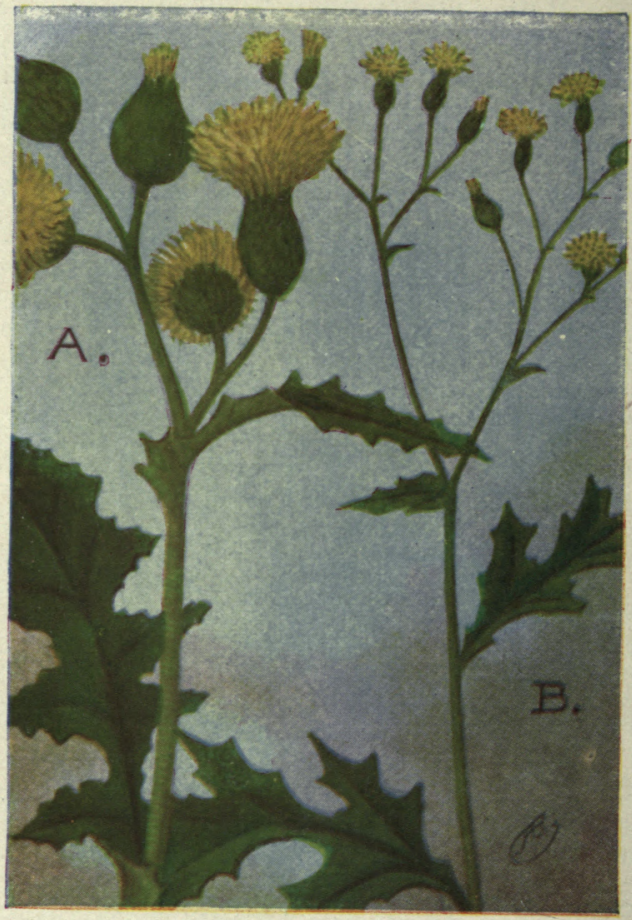

A. Sow Thistle.

Sonchus oleraceus.

B. Wild Lettuce.

Lactuca canadensis. 


\section{Wild Flowers East of the Rockies}

SOW THISTLE (Sonchus oleraceus) (EUROPEAN) is still another of the unwelcome weeds that has come across the water and made itself at home here. Unfortunately the government can establish no immigration bureau that can successfully keep out undesirable plant immigrants, for their seeds come over with all kinds of grain and are sown with them. Practically all foreign plants get their start in cultivated fields or as escapes from flower gardens. This species is not a real thistle at all and the name "Sow" is applied rather as a term of derision, signifying spurious or worthless. The specific name, Sonchus, is from the Greek signifying hollow, because the stem of this species is hollow.

The stem is stout, smooth, grooved, hollow and succulent; it attains heights of 1 to 6 feet. The leaves are shaped more like those of the dandelion than a thistle, but are armed with soft spikes. The small, thistle-like flower heads are light yellow; they grow in loose clusters, terminating the branches.

WILD LETTUCE (Lactuca canadensis) is one of the rankest-growing of our native plants. The milkyjuiced, branching, smooth stem ranges in height from 3 to 10 feet. The leaves are all very angular, cut, toothed and gouged in all manner of forms. Those near the base of the stem are very large, often attaining lengths of more than a foot. They become smaller and less deeply lobed as they mount the stem, the upper, small ones being almost entire-edged. The small, yellow-rayed flowers are numerous but uninteresting. At maturity they are succeeded by silky beards of down, proceeding from the deep-vase-like involucres. 


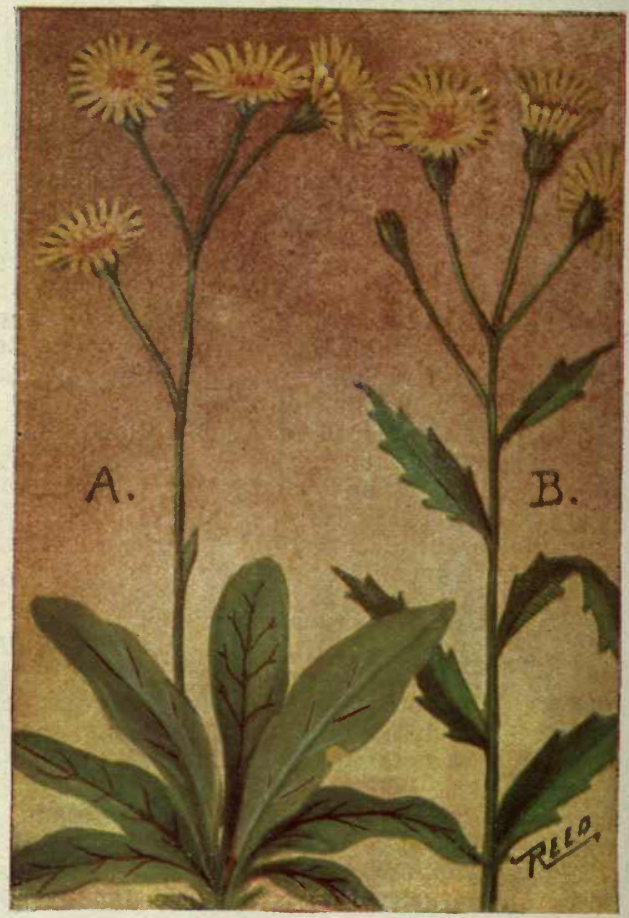

A. Rattlesnake-weed.

Hieracium venosum.

B. Canada Hawk-weed. Hieracium canadense. 
RATTLESNAKE-WEED (Hieracium venosum) is commonly found in dry sandy places and in open woods. It can readily be recognized by the tuft of spatulate leaves spreading from the root, each leaf having strong veinings of purple. A fertile imagination likens these veinings to the tongues of rattlesnakes,-hence the common name.

A solitary stem, branching slightly at the top, grows from the center of the tuft of leaves. It is without foliage, save for a few small, bract-like leaves. The flower heads are composed of bright, golden-yellow rays seated in a rather deep involucre; they resemble little dandelions but the rays are fewer in number, giving a more open construction to the flower. Rattlesnake-weed blooms from June until September and ranges from Me. to Minn. and southwards to Ga.

CANADA HAWKWEED (Hieracium canadense) is a smooth, slender, leafy-stemmed species. Besides the large, spreading, basal ones, the stem is alternately set with stemless, lance-shaped, sharplytoothed, light green leaves. The flowers are practically like those of the last species. In October, they are replaced by little brownish globes of down. Canada Hawkweed is common on the borders of woods from Newfoundland to British Columbia south to N. J., Mich. and Oregon. It blooms from July until September.

TAWNY HAWKWEED (Hieracium aurantiacum) (EUROPEAN) can always be recognized by the tawny-orange color of its flowers, the general hairiness of the stem and the basal tuft of lanceolate, hairy leaves; but two or three tiny leaves claps the flower stalk. The flowers are closely clustered on short hairy peduncles. It is common in fields, woodland and along roadsides from N. S. to Quebec and south to Pa., flowering from July until September. 


\section{KEY TO FLOWERS BY COLOR.}

The flowers are grouped under their most conspicuous colors, the ones the novice would be most apt to call them. As far as possible the smallest flowers are placed first in each section.

\section{WHITE AS THE CHIEF FLOWER-COLOR.}

False Spikenard.-Tiny; clustered.......... 49 False Solomon's Seal. -3 leaves on stalk...... 51 Meadow Rue.-Filmy cluster; 3-lobed leaves.... 123 Sundew.-Raceme; leaves hairy, basal........ 147 Saxifrage.-Cluster; 5 petals; basal leaves..... 149 Mitrewort.-Raceme; 5 petals, crystal-like..... 151 Foam Flower.-Feathery spike; leaves basal... 151 Meadowsweet.-Spire-like cluster .......... 153 White Clover.-Triple leaves; round heads..... 175 Ginseng.-Umbel; 3 compound leaves......... 227 Wild Carrot.-Flat cluster; divided leaves..... 229 Catnip.-Small clusters; aromatic........... 293 Rattlesnake Plantain.-Tubular, spiked ...... 95 Ladies' Tresses.-Spiral spike; tubular........ 95 Checkerberry.-Tubular, pendent; evergreen.... 247 Partridge Berry.-In pairs, 4-lobed........... 325 Violet.-5 petals, lower large, veined........ 215 Star-of-Bethlehem.-Umbel; grasslike leaves.... 67 Dutchman's Breeches. -2 sac-like spurs....... 139 Squirrel Corn.-Tubular, heart-shaped........ 139 Toothwort. -4 petals; 2 compound leaves...... 141 
Star Flower.-Above whorl of leaves .......... 259 Bladder Campion. -5 petals; inflated calyx...... 109 Evening Lychnis. -5 notched petals........... 109 Anemone.-5-6 sepals; delicate low herbs....... 125 Pipsissewa.-Cluster; 5 waxy petals........... 233 Shinleaf.-Raceme; 5 waxy petals .......... 235 Indian Pipe.-Cold, clammy white; no green.... 235 Turtle-head.-Tubular, 2-lipped; spiked........ 307 Cornel.-4-parted involucre. Low herb........ 231 Bloodroot.-Solitary; $6-10$ petals ............ 135 Mandrake.-Solitary; 6 petals; large leaves.... 133 Fringed Orchis.-Showy spike; lip fringed ..... 85 Trillium. -3 petals, 3 sepals; 3 leaves......... 65 Arrow-heads.-Aquatic; 3 petals ............ 23 Water Arum.-Aquatic; large white spathe..... 27 Grass of Parnassus.-5 petals, green-veined..... 149 Azalea.-Shrub; tubular, 5 spreading lobes..... 237 Laurel.-Clustered, Saucer-shaped; shrub ...... 243 Atamasco Lily._Erect, 6-parted; solitary....... 67 Lady's Slipper.-Large, white, slipper-shaped.... 77 Dogwood.-Shrub or tree; 4-parted involucre.... 231 Water Lily.-Floating, numerous petals....... 117

\section{BLUE AS THE CHIEF FLOWER-COLOR.}

Bluets.-Tiny, 4-lobed; white, blue -tipped ....325 Toadflax.-Spurred, hooded, tiny lip ...........305 Forget-me-not. -5 petals, yellow center .......285 Day Flower.-2 petals; delicate; spathed..... 31 Pickerel-weed-Aquatic; showy spike.......... 33 Mud Plantain.-Aquatic; kidney-shaped leaf..... 33 Fringed Gentian-4 spreading, fringed lobes....267 Bugloss-Leafy racemes; tubular, 5 lobes......287 Lobelia-Leafy spike; 3-lobed lip ............335 


\section{PURPLE OR MAGENTA COLORED FLOWERS.}

Blue-eyed grass-6-parted, white center....... 73 Sundew.-Raceme; leaves thread-like ....... 147 St. Johnswort.-Flesh color, 5 petals ........207 Speedwell-Axillary racemes, 4 petals ........311 Showy Orchis-Purple hood, white lip......... 93 Fringed Orchis-Showy spike; lips fringed .... 87 Cinquefoil-5-parted, calyx large ...........159 Lupine-Pea-like; 8-palmated leaflets .........167 False Indigo-Pea-like; 3-palmate leaflets . . . . . 167 Flax -5 large petals; tiny leaves..............183 Vervain -5 petals, tiny; slender spikes .......289 Self-heal-Short stout spike; hooded ........291 Skullcap-Spiked; tubular with hood and lip... 291 Ground Ivy-Prostrate;axillary flowers ......293 Monkey Flower-2 lobed upper; 3 lobed lower....309 Gerardia-Tubular, 5-lobed; linear leaves .......313 Hepatica $\longrightarrow 6$ petals; 3-lobed leaves; downy ....131 Spiderwort-Small cluster; 3 petals; hairy ..... 31 Violets -5 petals; lower large, veined ........211 Loosestrife-Showy spike; 5 long petals ......219 Milkweeds-Axillary clusters; milky juice .....277 Bittersweet -5 petals; yellow cone center .....299 Cranesbill-5 petals; palmate leaves .........189 Virgin's Bower-Large bell-shaped; 4 sepals.....127 Meadow Beauty-4 petals; long curved pistil....221 Closed Gentian-Tubular, closed ...........271 Phlox-Corymbed; 5 spreading petals ........283 Bluebell-Bell-shaped, 5-toothed; slender.......331 Bellflower-Showy spike; 5 toothed corolla ...331 Thorn Apple-Funnel-form; 5-pointed lobes ....301 
Morning Glory-Funnel-shaped; climbing ....281 Blue Flag-3 petals; 3 sepals variegated ....... 71 Wake-Robin -3 petals, 3 sepals, 3 leaves .....6 61

\section{BLUE OR MAGENTA COMPOSITES.}

Iron-weed-Tubular florets; clustered ........337 Blazing Star-" " " loose spike ......337 Joe Pye Weed-“" " flat clusters...........339 Burdock- “ " " spiny involucre ....387 Thistles- " " spiny leaves ........389 Asters-Blue or purple rays . . . . . . . . . 349

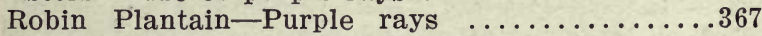
Chicory-Blue rays, notched at tip ...........393

\section{PINK AS THE CHIEF FLOWER-COLOR.}

Persicaria-Tiny, in slender spikes ..........103 Steeplebush-Steeple-like cluster ............153 Red Clover-Trifoliate; round flowerhead.......173 Twinflower-In pairs; crimson inside .........327 Dogbane -5-toothed, bell-shaped; spreading.....273 Arbutus-Creeping; 5-parted, fragrant .........247 Milkwort-Round scaly heads; small leaves ....193 Fringed Polygala-2 wing-like sepals .........191 Pogonia-Solitary; broad, crested lip ......... 91 Calopogon-Several; fringed lip at top ...... 89 Arethusa-Solitary; broad crested lip; erect .... 89 Bouncing Bet-5-parted, deeply lobed .........111 Spring Beauty-5-parted; grass-like leaves . ...115 Willow Herb-4 petals, slender pods; spike . ...223 Azalea-Tubular, 5-lobed; long stamens; shrub..239 Laurel-Clustered; saucer-shaped ..........245 Moss Pink-Creeping; 5 notched petals .......283 Sabbatia-Large; $10-12$ petals; 2 in. across ....265 


\section{Wild Flowers East of the Rockies}

Sea Pink-5 petals, crimson marks; showy $\ldots 263$ Rhododendron-5 petals, yellow spots; shrub ...241 Rose Mallow-5 petals; large, 3 in. across . ...203 Wild Rose-5 large petals; spiny stems ......163 Moccasin Flower-Large, slipper-shaped . ..... 79

\section{RED AS THE CONSPICUOUS FLOWER-COLOR.}

Wood Lily-Deep orange-red, spotted; erect .... 41 Columbine-Pendulous; 5-spurred ............129 Pitcher Plant-Leaves hollow .............145 Pimpernel-Coper-red, 5 petals; sandy soil ....259 Oswego Tea-Striking, tubular; round heads ...297 Painted Cup-Floral leaves scarlet tipped .....315 Coral Honeysuckle-Slender, yellow within . ...329 Cardinal Flower-Lip 3-lobed; velvety ........333

\section{ORANGE AS THE CHIEF FLOWER-COLOR.}

Jewel-weed-Pendent; pouch-like, spurred .....197 Butterfly-weed-Terminal cluster; brilliant ...275 Toadflax-Yellow spur and lip; orange palate ...305 Trumpet Creeper-Large trumpet-shaped; vine ..321 Turk's Cap Lily-Reflexed, spotted; leafy....... 43 Day Lily-Erect; basal, sword-shaped leaves .. 39 Hawkweed-Rays in several ranks ..........401 Dandelions-Rays in several ranks . . . . . . . 395 Tansy - Flat clusters, no rays................. 383 Golden-rods-Plume-like spikes; $5-12$ rays $\ldots . .345$ Golden Aster-Golden rays; sandy soil ........341 Elecampane-Slender, yellow rays; disc .......365 Sunflowers-Yellow rays, large disc .........373 Coneflower-Orange rays, purple cone disc . . . . 369 Ragwort-Orange rays and small disc .........385 


\section{YELLOW AS THE CHIEF FLOWER-COLOR,}

Golden Club-Aquatic; club-shaped spike ...... 27 Hop Clover-Cylindrical, scaly heads..........177 Yellow Flax-Tiny flowers; tiny leaves .......183 Hudsonia-Tiny flowers; scale-like leaves ....209 Fly Honeysuckle-Axillary in pairs; tubular ...327 Wood Sorrel-5 petals; delicate; trifoliate ....187 Wild Indigo-Pea-like, racemed; trifoliate ....169 Cinqfoil-5 petals; 5-palmate leaflets ........157 Mustard-4 petals, slender pods; clusters .....143 Celandine -4 petals, slender pods; orange juice..137 Yellow Star Grass-6 sepals; grass-like ......6 69 Dog-tooth Violet-Solitary, 6-parted .......... 47 Clintonia-6-parted; 3 oval, basal leaves ....... 47 St. Johnswort -5 petals, many long stamens ...205 Violet -5 petals; lower large, veined.........217 Loosestrife-Showy spike; 5 petals, basal spot..253 “ Axillary; leaves whorled in fours ...253 Myrtle-Creeping; axillary, 5 petals .........255 Mullein-Long spike, 5 petals; woolly ........303 Moth Mullein-Raceme; 5 large petals ........303 Fringed Orchis-Showy spike; lip fringed .....83 Cowslip-5 shining petals; clustered........... 119 Buttercup -5 shining petals ...............121 Partridge Pea-5 petals; pinnate leaves .......171 Frostweed-5 petals; axillary; small leaves ...209 Primrose -4 petals; coarse stem and leaves.....225 Sundrops-4 petals; slender stem ............225 Foxglove-Tubular, 5-lobed; leafy spike ........313 False Jessamine-5-lobed; climbing, tubular ...261 Yellow Pond Lily-Aquatic; floating leaves ....117 
Lady's Slipper-Solitary, slipper-shaped ..... 75 Canada Lily-Pendulous; leafy stem ......... 45

\section{BROWNISH, GREENISH OR INCONSPICUOUS.}

Cat-tails-Cylindrical brown heads .......... 19 Bur-Reeds-Spherical brown-yellow heads ..... 21 Indian Turnip-Large striped spathe ......... 25 Skunk Cabbage-Large spathe set on ground ... 29 Solomon's Seal-In pairs from axils, greenish .. 55 Cucumber-root-3, 3-parted spiderlike flowers.... 59 Green-fringed Orchis-Lips fringed; spiked ... 81 Wild Ginger-Tubular, 3-lobed; near roots....... 99 Stone Clover-Fuzzy gray heads; trifoliate .....173 Ground Nut-Spherical, pea-like clusters .....181 Wood Betony-2-lipped; clustered; fern-like . ...317 Beech Drops-Resembling little twigs .........319 


\section{N D E X}

Achillea millefolium .................. 381 Aconite ......................... 131 Acontium uncinatum .................. 131 Adder's-tongue ................... 47 Agrimonia gryposepola $\ldots \ldots \ldots \ldots \ldots \ldots \ldots \ldots$ Agrimony $\ldots \ldots \ldots \ldots \ldots \ldots \ldots \ldots \ldots \ldots \ldots \ldots \ldots \ldots \ldots$ Agrostemma githago ................. 107 Aletris farinosa .................... 59

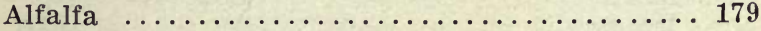
Allium ........................ 37 Amphicarpa monoica ................ 181 Anagallis arvensis $\ldots \ldots \ldots \ldots \ldots \ldots \ldots \ldots \ldots 259$ Anaphalis margaritacea ................. 361 Anemone quinquefolia ................ 125 " Rue ...................... 125 " patens ..................... 123

" Wood ....................... 125

Anemonella thalictroides .............. 125

Anthemis Cotula .................... 381

Apios tuberosa ..................... 181

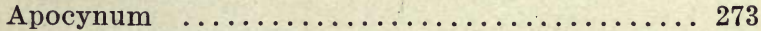

Aquilegia canadensis . . . . . . . . . . . . 129

Aralia nudicaulis ................... 227

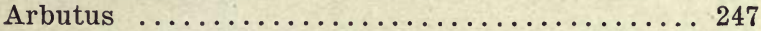

Arctium minus ................... 387

Arethusa ........................ 89

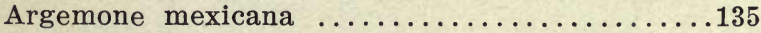

Arisaema dracontium ............... 25

" triphyllum $\ldots \ldots \ldots \ldots \ldots . \ldots \ldots \ldots .25$ 
Aristolochia $\ldots \ldots \ldots \ldots \ldots \ldots \ldots \ldots \ldots \ldots \ldots$

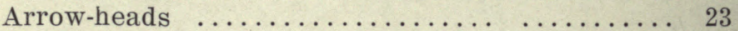

Arnica mollis ..................... 385

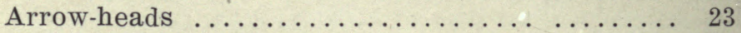

Artichoke, Jerusalem ............... 375

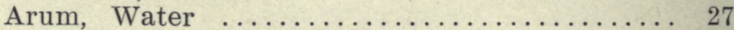

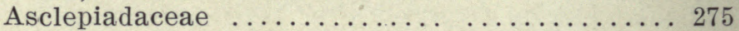

Asparagus officinalis $\ldots \ldots \ldots \ldots \ldots \ldots \ldots \ldots \ldots \ldots$

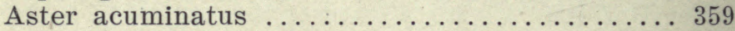

"Cordifolius .................... 353

" ericoides ..................... 355

" Golden ..................... 341

" Heath ............ ........... 355

"Heart-leaved .................. 353

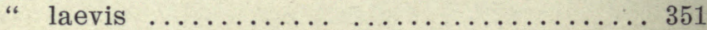

“ laterifolius .................... 357

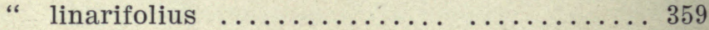

“ multiflorus .................... 355

“ New England .................. 349

“ New York ............ .......... 351

"Smooth ..................... 351

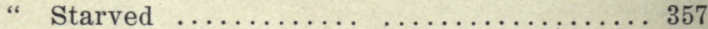

“ umbellatus ..................... 359

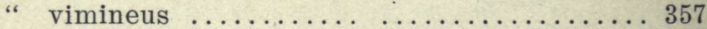

“ Wood ....................... 359

Avens .............................. 161

Azalea ......................... 237

Baptisia australis ................ 167

tinctoria $\ldots \ldots \ldots \ldots \ldots \ldots \ldots \ldots \ldots$

Bean, Wild ...................... 181

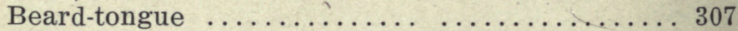

Bedstraws ........................ 325

Bee Balm .......................... 297

Beech Drops ....................... 319

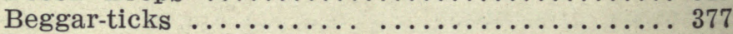

Belamcanda ...................... 71 


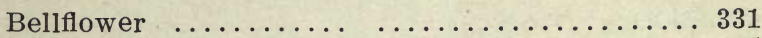

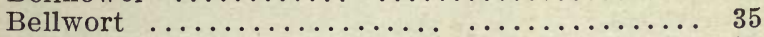

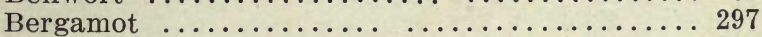

Betony, Wood ....................... 317

Bidens frondosa .............................. 377

“ laevis .......................... 377

Bignonia Family .................... 321

Bindweed, Hedge .................... 281

Bitter Buttons ...................... 383

Bittersweet ....................... 299

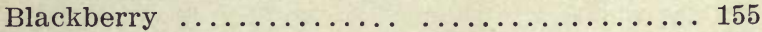

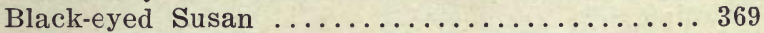

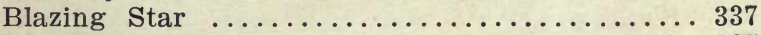

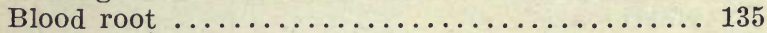

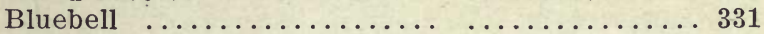

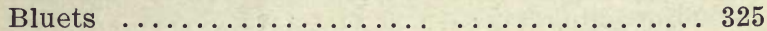

Blue-weed ..........................287

Boneset ........................... 339

Borage Family ..................... 285

Bouncing Bet ...................... 111

Brassica nigra ..................... 143

Brauneria purpurea .................... 367

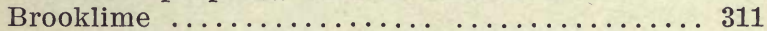

Broom-rape .......................... 319

Bugleweed ........................ 291

Bugloss .......................... 287

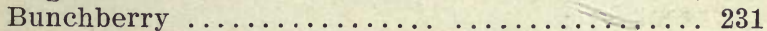

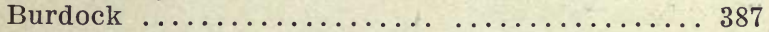

Bur-Marigold ....................... 377

Bur-Reeds ....................... 21

Butter-and-eggs ....................... 305

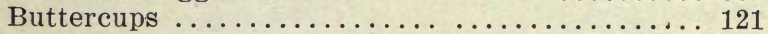

Calla palustris $\ldots \ldots \ldots \ldots \ldots \ldots \ldots \ldots \ldots . \ldots \ldots$

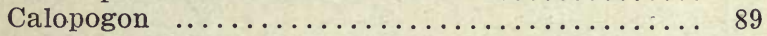

Caltha palustris .................... 119

Calypso bulbosa ................... 89 
Camassia esculenta ................... 39

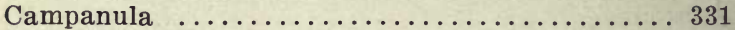

Campion, Bladder .................... 109

Cancer-root ......................... 319

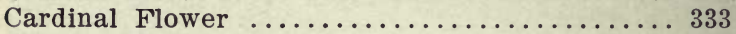

Carrion Flower ................... 57

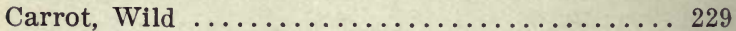

Cassia Chamaecrista .................. 171

Castalia odorata ................... 117

Castilleja coccinea .................... 315

Cat-gut $\ldots \ldots \ldots \ldots \ldots \ldots \ldots \ldots \ldots \ldots \ldots \ldots \ldots \ldots \ldots \ldots \ldots$

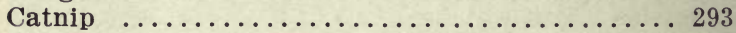

Cat-tails ........................ 19

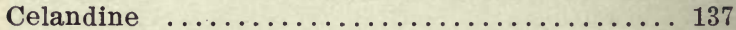

Centaurea nigra .................... 393

Cerastium arvense ....................... 105

Chamaedaphne ..................... 249

Chamomile ........................ 381

Charlock ......................... 143

Checkerberry ..................... 247

Chelidonium majus .................. 137

Chelone glabra ................................ 307

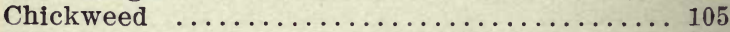

Chicory .............................. 393

Chimaphila maculata ................. 233

“ umbellata ....................... 233

Chrysanthemum ..................... 379

Chrysopsis falcata ..................... 341

“ mariana ......................... 341

Cichorium Intybus . . . . . . . . . . . . 393

Cinquefoils ........................ 157

Cirsium arvense ..................... 389

pumillum ................... 391

lanceolatum .................... 391

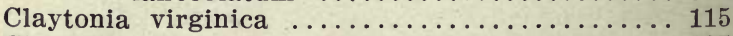

Clematis .................., , , . 127 
Clintonia ....................... 47

Clover, Prairie ..................... 169

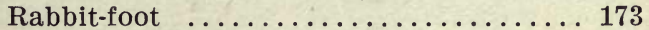

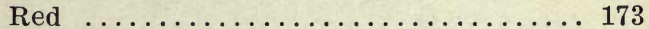

White ..................... 175

Yellow ................... 177

Colic-root ....................... 59

Columbine, Wild .................... 129

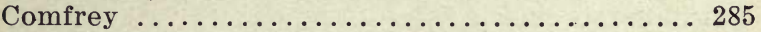

Commelina communis ................ 31

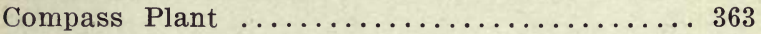

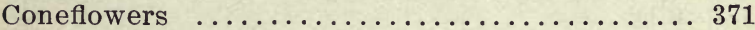

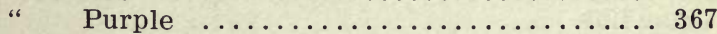

Convallaria majalis $\ldots \ldots \ldots \ldots \ldots \ldots \ldots \ldots, 57$

Convolvulus sepium .................. 281

Coptis trifolia .................... 129

Cooperia Drummondii ................ 69

Corallorrhiza .................... 97

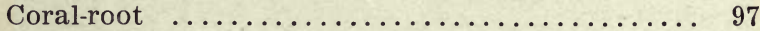

Corn Cockle ...................... 107

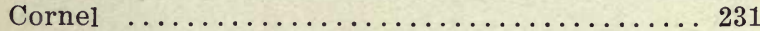

Cornus florida ...................... 231

" canadensis ...................2231

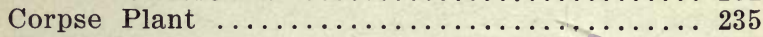

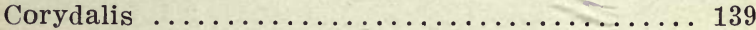

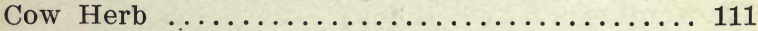

Cowslip ......................... 119

" american ....................255

Cow-Lily ....................... 117

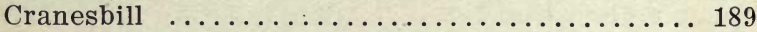

Crotolaria sagittalis $\ldots \ldots \ldots \ldots \ldots \ldots \ldots \ldots 169$

Crowfoot Family ................... 119

Cucumber-root, Indian $\ldots \ldots \ldots \ldots \ldots \ldots \ldots . \ldots 59$

Cuscuta Gronovii ....................281

Cynoglossum virginianum .............. 285

Cypripedium ..................... 75 
Daisy, Ox-eye .......................... 379

“ White .......................... 379

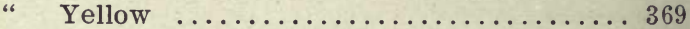

Dalibarda repens .................... 161

Dandelions, Common .................. 397

“ Fall

395

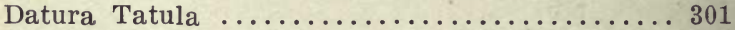

Daucus Carota ......................... 229

Day-flower .......................... 31

Dentaria diphylla ..................... 141

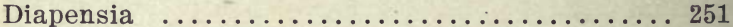

Dianthis Armeria ..................... 113

Dicentra Cucullaria .................... 139

Dock, Prairie ......................... 363

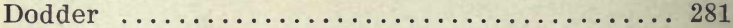

Dodecatheon Meadia ....................25 255

Dogbane ......................... 273

Dogwood, Flowering ................... 231

Draba verna ....................... 141

Droscera rotundifolia ................. 147

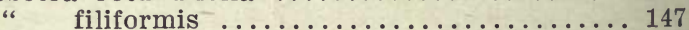

Dutchman's Breeches .................. 139

Echium vulgare ..................... 287

Eglantine ........................... 165

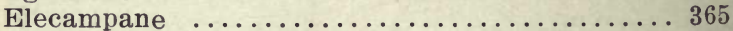

Epifagus virginiana ................... 319

Epigaea repens ...................... 247

Epilobium angustifolium $\ldots \ldots \ldots \ldots \ldots \ldots \ldots \ldots 223$

“ hirsutum ..................... 223

Erigeron pulchellus .................... 367

“ ramosus ........................ 357

Erythronium ............................ 47

Eupatorium perfoliatum ................ 339

“ purpureum ..................... 339

Euphorbia ........................... 195

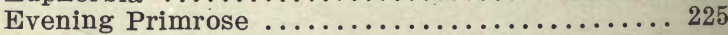




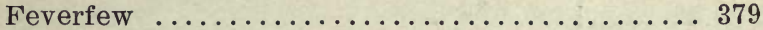

Figwort Family .................... 303

Flag, Blue ..................... 71

Flax ........................... 183

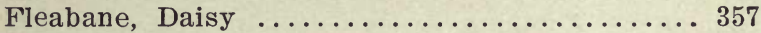

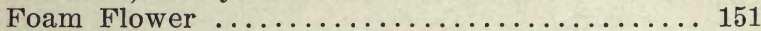

Forget-me-not ..................... 285

Fragraria virginiana ................. 155

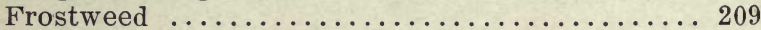

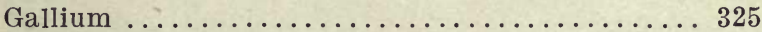

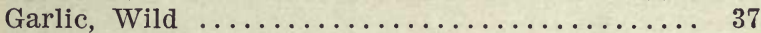

Gaultheria procumbens ............... 247

Gelsemium sempervirens ...............261

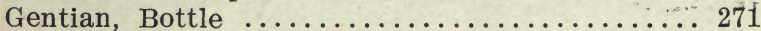

" Closed ......................271

“ Downy ......................269

“ Fringed ....................267

“ Solitary ........................ 269

Gentiana Andrewsii .................. 271

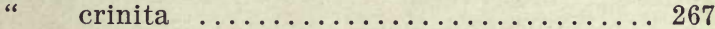

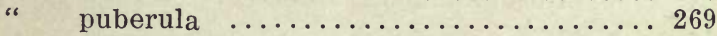

“ quinquefolia ..................269

Geranium maculatum ................. 189

“ Robertianum .................. 189

“ Wild ....................... 189

Gerardia, Purple ................... 313

" purpurea .................... 313

Geum strictum .................... 161

Gill-over-the ground $\ldots \ldots \ldots \ldots \ldots \ldots \ldots \ldots 293$

Ginger, Wild ................... 99

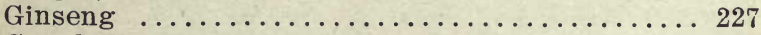

Gnaphalium polycephalum .............. 361

Goat's Rue ........................ 171

Golden Club ..................... 27 
Golden-rod, Blue-stemmed ............... 343 " Canada .......................... 345

“ Early ......................... 345

“ Lance-leaved ................... 347

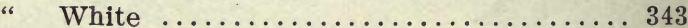

Goldthread ........................ 129

Grass, Blue-eyed ..................... 73

Grass of Parnassus ................. 149

Grass Pink ....................... 89

Green Brier ...................... 57

Green Dragon ...................... 25

Ground Nut ........................ 181

Ground Ivy $\ldots \ldots \ldots \ldots \ldots \ldots \ldots \ldots \ldots \ldots \ldots \ldots \ldots \ldots$

Habenaria clavellata .................. 81

“ ciliaris ..................... 83

“ fimbriata ................... 87

“ lacera ......................... 85

Hardhack ........................ 153

Harebell ........................... 331

Hawkweed, Canada .................... 401

Heal-all ............................ 291

Hedge Nettle ......................... 273

Helenium autumnale .................. 383

Helianthemum canadense ................ 209

Helianthus anius .................... 373

“ decapetalous ................. 373

“ tuberosus ................... 375

Hemerocallis fulva ................... 39

Hemp, Indian ....................... 273

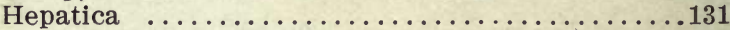

Heteranthera reniformis $\ldots \ldots \ldots \ldots \ldots \ldots \ldots .33$

Hibiscus Moscheutos ................... 201

Hieracium canadense .................. 401

" venosum .................. 401 
Honeysuckle, Coral ................... 329

“ Fly ........................... 327

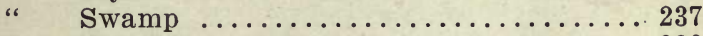

“ Trumpet ...................... 329

Houstonia caerulea ................... 325

Hudsonia ......................... 209

Hyacinth, wild .................... 39

Hymenocallis ..................... 67

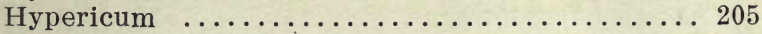

Hypoxis hirsuta $\ldots \ldots \ldots \ldots \ldots \ldots \ldots \ldots \ldots \ldots \ldots$

Impatiens biflora ................... 197

Indian Paint Brush ................... 315

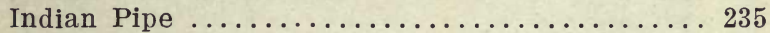

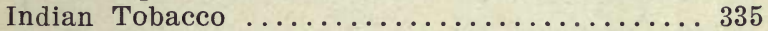

Indian Turnip .................... 25

Indigo, Blue false $\ldots \ldots \ldots \ldots \ldots \ldots \ldots \ldots \ldots . \ldots \ldots$

" Wild ....................... 169

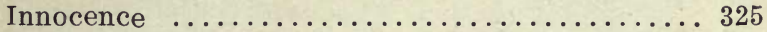

Inula Helenium .................... 365

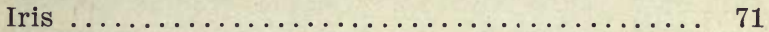

Ironweed $\ldots \ldots \ldots \ldots \ldots \ldots \ldots \ldots \ldots \ldots \ldots \ldots \ldots \ldots \ldots$

Jack-in-the-Pulpit $\ldots \ldots \ldots \ldots \ldots \ldots \ldots \ldots \ldots \ldots$

Jeffersonia diphylla .................. 133

Jessamine, Yellow False ............... 261

Jewel-weed ...................... 197

Job's Tears ....................... 31

Joe Pye Weed ....................... 339

Kalmia angustifolia $\ldots \ldots \ldots \ldots \ldots \ldots \ldots \ldots 245$

“ latifolia ..................... 243

Krigia virginica .................... 395

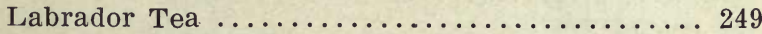

Lactuca canadense ..................... 399

Ladies' Tresses ..................... 95 
Lady's Slipper, Pink ................ 79

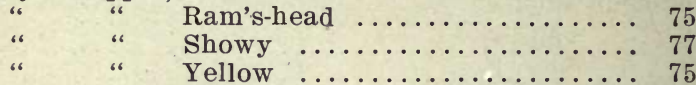

Lady's Thumb ..................... 103

Laurel, Mountain .................... 243

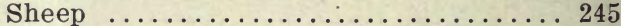

Leatherleaf ......................... 249

Ledum groenlandicum . . . . . . . . . . . 249

Leek, Wild ...................... 37

Leontodon autumnalis ................ 395

Leonurus Cardiaca .................... 295

Lettuce, Wild ....................... 399

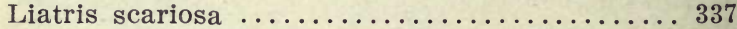

Lilium canadense .................. 45

“ philadelphicum ................ 41

“ superbum .................. 43

Lily, Atamasco ................... 67

" Blackberry ................... 71

" Cow ....................... 117

" Day ....................... 39

“ Red Wood ..................... 41

“ Turk's-cap .................... 43

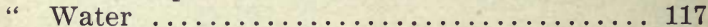

Lily-of-the-Valley .................. 57

Limonium carolinianum ............... 251

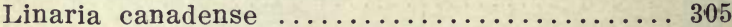

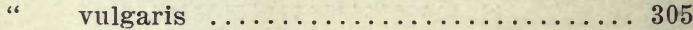

Linnaea borealis ................... 327

Linum virginianum ................. 183

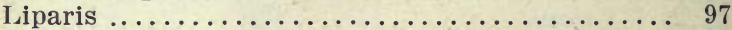

Listera cordata ........................ 97

Liverwort ...................... 131

Lobelia cardinalis .................... 333

“ Great .................... 335 
Lobelia inflata ................... 335

" spicata ........................ 335

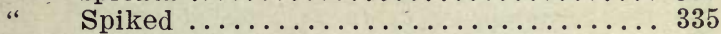

Lonicera canadensis .................. 327

“ sempervirens ................... 329

Loosestrife, Four-leaved ............... 253

“ Fringed .................. 257

“ Purple ....................... 219

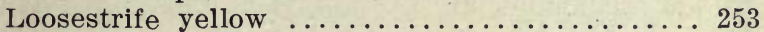

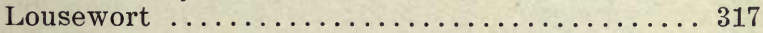

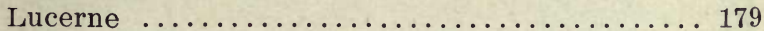

Lupine, Wild ...................... 167

Lupinus perennis .................. 167

Lychnis .......................... 109

Lycopsis arvensis .................... 287

“ virginica .................... 291

Lysimachia ...................... 253

Lythrum Salicaria .................. 219

Madder Family ..................... 325

Mainthemum canadense .............. 51

Mallow, Common ........................ 199

“ Mush .....................201

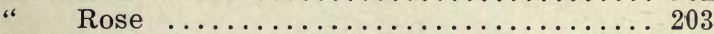

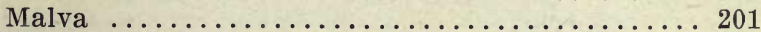

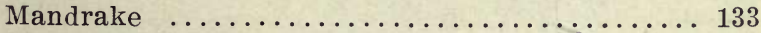

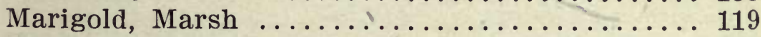

Marsh Rosemary ..................... 251

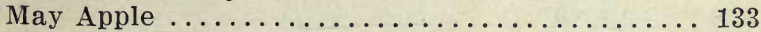

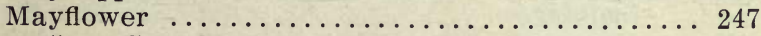

“ Canada ....................... 51

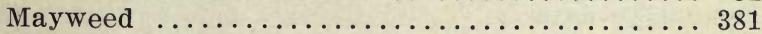

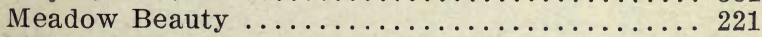

Meadow Rue ........................ 123

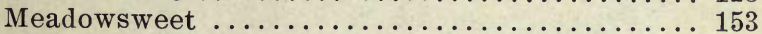

Medeola virginiana $\ldots \ldots \ldots \ldots \ldots \ldots \ldots \ldots \ldots \ldots$

Medicago sativa ...................... 179 
Melilot, Yellow .................... 177

Melilotus officinalis ................... 177

Mentha arvensis . ....................... 295

Milfoil $\ldots \ldots \ldots \ldots \ldots \ldots \ldots \ldots \ldots \ldots \ldots \ldots \ldots \ldots, 381$

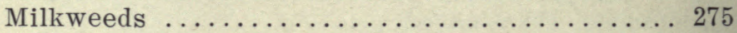

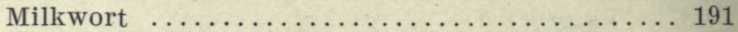

Mimulus ringens . . . . . . . . . . . . . . . 309

Mint Family ........................ 291

Mitchella repens $\ldots \ldots \ldots \ldots \ldots \ldots \ldots \ldots \ldots \ldots . \ldots . \ldots 25$

Mitella nuda ......................... 151

“ diphylla ..................... 151

Mitreworts ....................... 151

Monarda didyma ..................... 297

Moneses uniflora ...................... 235

Monotropa Umflora ................... 235

Moneywort . . . . . . . . . . ., . . . . . . . 255

Monkeyflower ........................ 309

Monkshood ......................... 131

Motherwort ........................ 295

Mud Plantain ....................... 33

Mullein, Common ..................... 303

“ Moth .............................. 303

Mustard .......................... 143

Myosotis scorpiodes $\quad \ldots \ldots \ldots 285$

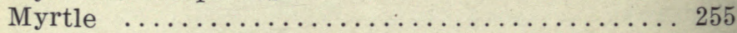

Nemastylis acuta $\ldots \ldots \ldots \ldots \ldots \ldots \ldots \ldots \ldots .73$

Nepeta cataria ........................ 293

“ hederacea ................... 293

Nightshade $\ldots \ldots \ldots \ldots \ldots \ldots \ldots \ldots \ldots \ldots \ldots . \ldots \ldots 299$

Nymphaea advena ................... 117

Oakesia ............................ 35

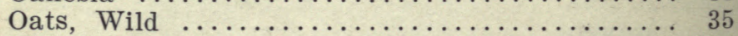

Oenothera biennis ..................... 225

" fructicosa ...................... 225 
Orchis, Green Wood ................. 81

" Purple-fringed $\ldots \ldots \ldots \ldots \ldots \ldots \ldots \ldots \ldots, 87$

“ Ragged-fringed ................ 85

“ Round-leaved .................. 83

" Showy ..................... 93

" spectabilis .................... 93

“ Yellow-fringed ................ 83

Orontium aquaticum $\quad \ldots \ldots 27$

Ornithogalum umbellatus .............. 67

Orobanche uniflora ................... 319

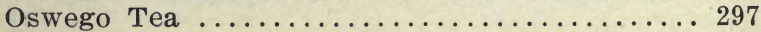

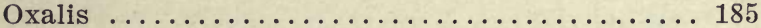

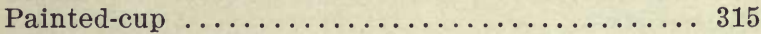

Panax quinquefolium ................. 227

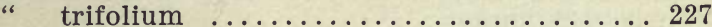

Parnassia caroliniana ................. 149

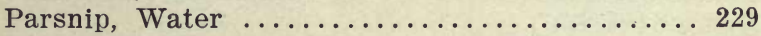

Pasque Flower ..................... 123

Peanut, Wild ...................... 181

Pea, Partridge .................... 171

Peducularis canadensis . . . . . . . . . . . . 317

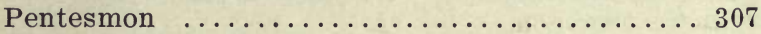

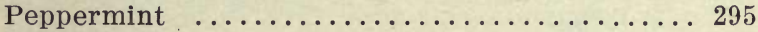

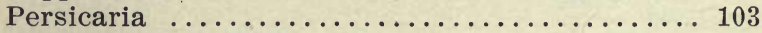

Petalostemum purpureum ............... 169

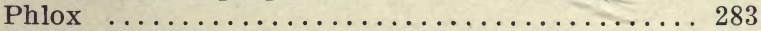

Pickerel-weed ...................... 33

Pimpernel ........................ 259

Pink, Fire ....................... 113

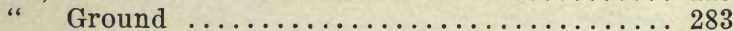

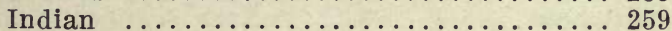

Maiden ...................... 113

Marsh .......................265

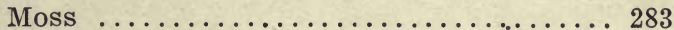

Mullein .................... 107

Rose ....................... 263

Wild $\ldots \ldots \ldots \ldots \ldots \ldots \ldots \ldots \ldots \ldots . \ldots 113$ 


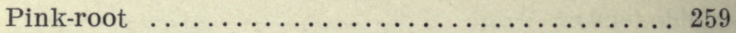

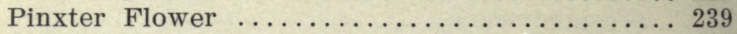

Pipsissewa $\ldots \ldots \ldots \ldots \ldots \ldots \ldots \ldots \ldots \ldots \ldots . \ldots . \ldots 233$

Pipe Vine ............................ 101

Pipe, Dutchman's ...................... 101

Pitcher Plant ........................ 145

Plantain, Common ...................... 323

“ Robin's ...................... 367

“ Water ........................... 119

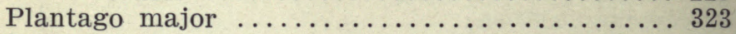

Pogonia ............................ 91

Polygala ............................. 191

Polygonatum ........................ 55

Polygonum persicaria .................. 103

Polymonium Family .................... 283

Pontederia cordata .................... 33

Poppy, Prickly ....................... 135

Portulaca oleracea .................... 115

Potentilla canadensis . . . . . . . . . . . . 157

“ palustris ........................ 159

Primrose, Evening . . . . . . . . . . . . . 225

Prince's Pine ......................... 233

Prunella vulgaris $\ldots \ldots \ldots \ldots \ldots \ldots \ldots \ldots \ldots \ldots \ldots . \ldots \ldots 1$

Purslane ............................ 115

Pyrola elliptica ....................... 235

Pyxie .............................. 249

Ragged Robin ..................... 107

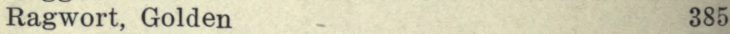

Ranunculus .......................... 119

Rattlebox ............................... 169

Rattlesnake Plantain .................... 95

Rattlesnake-weed ....................... 401

Rhexia virginica $\ldots \ldots \ldots \ldots \ldots \ldots \ldots \ldots \ldots . \ldots 221$ 
Rhododendron ..................... 241

“ canadense ....................239

" maximum ................... 241

“ nudiflorum .................. 239

“ viscosum .................. 237

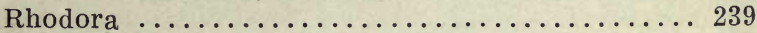

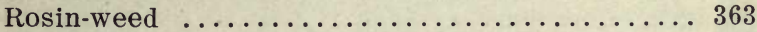

Rock-rose .......................... 209

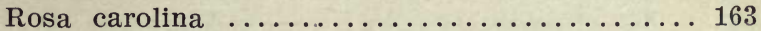

" rubiginosa ...................... 165

Rose, Pasture ..................... 163

“ Sweetbrier ........................ 165

Rubus allegheniensis .................. 155

Rudbeckia hirta .................... 361

" laciniata ......................... 371

Rumex acetosella ................... 103

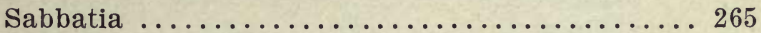

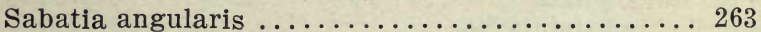

“ dodecandra .................... 265

" stellaris .....................263

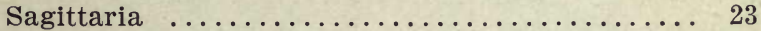

Sanguinaria canadensis ................ 175

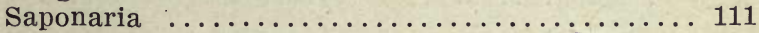

Sarracenia purpurea ................. 145

Sarsaparilla, Wild .................. 227

Saxifraga virginiensis . . . . . . . . . . . 149

Saxifrage, Early ..................... 149

Scutellaria intergrifolia ............... 291

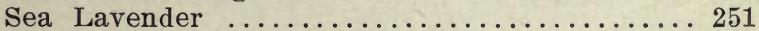

Self-heal ......................... 291

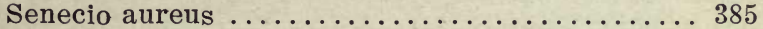

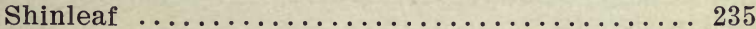

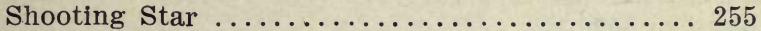

Silene latifolia .................... 109

“ virginica ..................... 113

Silphium lacinatum ................. 363 


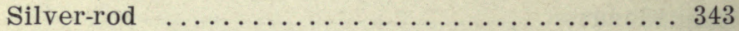

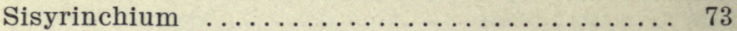

Sium cicutaefolium ................. 229

Skullcap ........................ 291

Skunk Cabbage ...................... 29

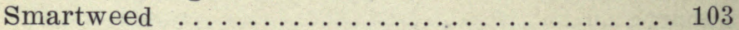

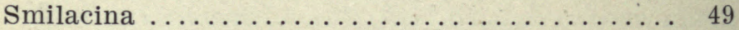

Smilax ........................ 57

Snakeroot, Virginia ................... 101

Sneezeweed ....................... 383

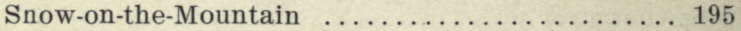

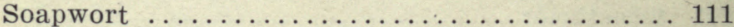

Solanum Dulcamara .................... 299

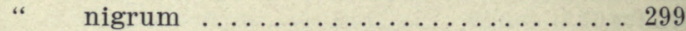

Solidago bicolor ................... 343

“ caesia .................... 343

" canadensis ................ 345

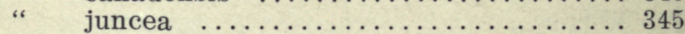

“ graminifolia ................. 347

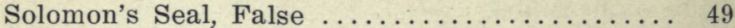

" "True ................ 55

Sonchus oleraceus .................. 399

Sorrel, Sheep .................... 103

Wood ...................... 185

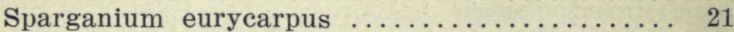

Specularia perfoliata ................ 331

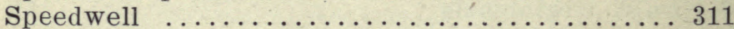

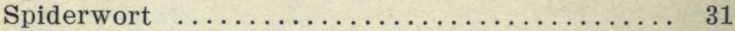

Spigelia marilandica ................ 261

Spikenard ....................... 49

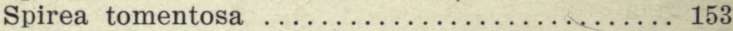

" salicifolia $\ldots \ldots \ldots \ldots \ldots \ldots \ldots \ldots \ldots \ldots \ldots 153$

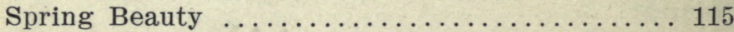

Spurge, Cypress ................... 195

Squirrel Corn ...................... 139

Stachys palustris .................. 295 
Star Flower ...................... 259

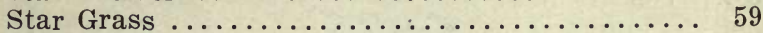

" " Yellow .................... 69

Star-of-Bethlehem ................... 67

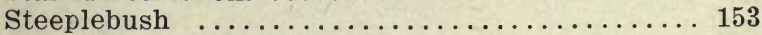

Steironema ciliatum ................. 257

Stellaria ......................... 105

St. Johnswort, Common ................ 205

“ Marsh ................... 207

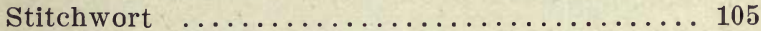

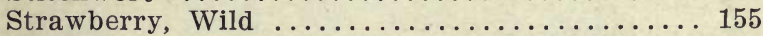

Streptopus ..................... 53

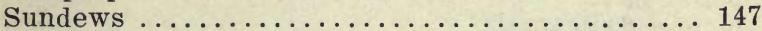

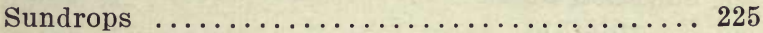

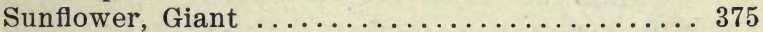

“

“ Ten-petalled

Sweetbrier
373

373 165

Tanacetum vulgare $\ldots \ldots \ldots \ldots \ldots \ldots \ldots \ldots \ldots 38$

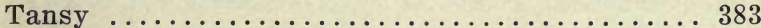

Taraxacum officinalis .................. 397

Tecoma radicans ...................... 321

Tephrosia virginiana ................. 171

Thalictrum polygamum ............... 123

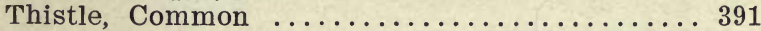

“ Canada ................................ 389

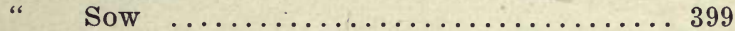

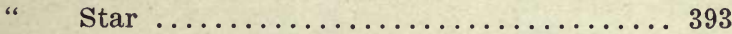

Thorn Apple ......................... 301

Thoroughwort ...................... 399

Tiarella cordifolia ................... 151

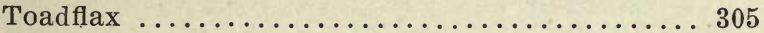

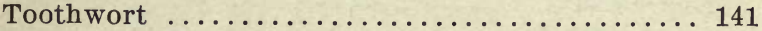

Touch-me-not ....................... 197

Tradescantia virginiana ............... 31

Trifolium .......................... 173 
Trientalis americana $\ldots \ldots \ldots \ldots \ldots \ldots \ldots \ldots 259$

Trilliums ......................... 61

Trumpet Creeper ......................... 321

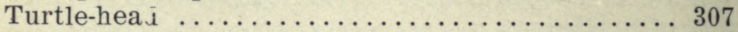

Twayblade ........................... 97

Twin Flower $\ldots \ldots \ldots \ldots \ldots \ldots \ldots \ldots \ldots \ldots \ldots \ldots$

Twinleaf $\ldots \ldots \ldots \ldots \ldots \ldots \ldots \ldots \ldots \ldots \ldots \ldots \ldots \ldots$

Twisted-stalk ....................... 53

Typha angustifolia $\ldots \ldots \ldots \ldots \ldots \ldots \ldots \ldots \ldots . \ldots \ldots$

latifolia $\ldots \ldots \ldots \ldots \ldots \ldots \ldots \ldots \ldots \ldots$

Uvularia perfoliata $\ldots \ldots \ldots \ldots \ldots \ldots \ldots \ldots, \quad 35$

Venus' Looking Glass . ................ 331

Verbascum ......................... 303

Verbena ........................... 289

Vernonia noveboracensis $\ldots \ldots \ldots \ldots \ldots \ldots \ldots . \ldots 337$

Veronica $\ldots \ldots \ldots \ldots \ldots \ldots \ldots \ldots \ldots \ldots \ldots . \ldots . \ldots . \ldots 11$

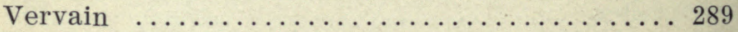

Vetch, Cow ....................... 179

Vicia Cracea ......................... 179

Viola blanda ......................... 215

canadensis .................... 213

cucullata ...................... 213

lanceolata ...................... 215

palmata ........................ 211

pedata ....................... 211

pubescens ....................... 217

Violet, Bird-foot ..................... 211

Common ...................... 213

Canada ......................... 213

Dog-toothed ................... 47

Palmated ...................... 211

White $. . . \ldots \ldots \ldots \ldots \ldots \ldots \ldots \ldots \ldots . \ldots 215$

Yellow ....................... 217

Virgin's Bower ...................... 127 


\section{Index}

Whitlow Grass .................... 141

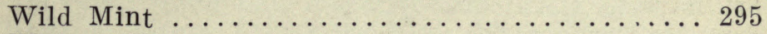

Willow Herb ....................... 223 “ “ Hairy ..................... 223

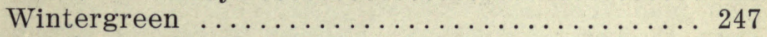
" Spotted .................... 233

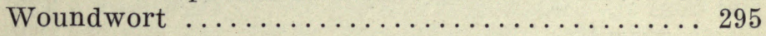





\section{LAND BIRDS EAST OF THE ROCKIES \\ By Chester A. Reed, S. B.}

EVERY song and insectivorous BIRD East of the Rockies (from Parrot to Blue bird) described and SHOWN IN NATURAL COLORS:

This is an illustrated, pocket text book that will enable anyone to quickly identify any land or song bird found east of the Rocky Mountains. It will not only name the birds for you, but describe their habits and peculiarities; and tells you where to look for them; describes their nests and eggs and songs.

EVERY BIRD IS SHOWN IN COLOR, including the females and young where the plumage differs. These plates are made from watercolor drawings by the 4-color process. The illustrations are the BEST, the MOST ACCURATE, and the MOST VALUABLE ever printed in a bird book.

"LAND BIRDS" is the most popular and has had the LARGEST SALE of any bird book published in this country. It is used and recommended by our leading Ornithologists and teachers. 240 pages.

Bound in Cloth, $75 \mathrm{c}$; postpaid; in leather, $\$ 1.00$, postpaid.

\section{COLOR KEY TO N. A. BIRDS.}

By Frank M. Chapman and C. A. Reed.

This book is designed especially for that great class of Nature-lovers who would "name the birds withcut a gun."

It might well be called an illustrated dictionary of North American hirds, the male of each species being shown in Color from pen and ink drawings.

As this book includes all the birds found in North America, it is equally useful in any part of the country from the Atlantic to the Pacific, from the Gulf to the Arctic Ocean. It is bound in cloth uniformly with the egg book.

300 pages $-6 \times 9$ inches.

$\$ 2.50$ postpaid. 


\title{
NORTH AMERICAN
}

BIRDS' EGGS.

\author{
By C. A. Reed, S. B.
}

This is the only book on the market that gives il lustrations of the eggs of all North American birds. Each egg is shown full size photographed directly from an authentic and well marked specimen.

In addition to the illustrations of eggs, there are a great many full page plates of nests and eggs in their natural situations.

The habitat and nesting habits of each bird are given. Marginal sketches give the reader an accurate idea of each bird.

It is finely printed on the best of paper and handsomely bound in cloth. 350 pages $-6 \times 9$ inches.

$\$ 2.50$ postpaid.

\section{GUIDE TO THE MUSHROOMS}

By Emma L. Taylor Cole.

"How do you tell a mushroom from a toadstool?" is a question frequently asked. They are the same, but there are both edible mushrooms and poisonous ones. The purpose of this book is to tell the differ ences. It tells HOW, WHEN and WHERE they grow; how to collect and prepare them for the table; and describes the common kinds, both edible and poiscnous. It is handsomely illustrated with about 70 halftones from photographs of living mushrooms and five PLATES IN COLOR.

Finely printed; finely bound; uniform with Wild Flowers.

$\$ 1.50$ net; postage $12 \mathrm{c}$. 


\section{WATER BIRDS EAST OF THE ROCKIES}

By Chester A. Reed, S. B.

Every WATER BIRD, GAME BIRD and BIRD OF PREY, described and shown IN COLOR.

This is the companion volume to "Land Birds," the two books including EVERY BIRD that has been found east of the Rocky Mountains. The descriptions include the habits, the range, the nests and eggs and the notes of each species. Each species is ilIustrated IN COLOR showing the characteristic mark ings, from pen and ink drawings. It is a very useful volume and, while it appeals especially to sportsmen as it contains the game birds, it should be in the li brary of everyone, together with Land Birds.

250 pages; cloth, 50 c.; leather, $75 \mathrm{c}$., postpaid.

\section{GOLDFISH-AQUARIA and FERNERIES.}

The above is the title of an excellent little book that tells in detail how to make aquaria. How to fit them up; all about goldfish of all kinds and how to breed them. About the very interesting Paradise Fish and all fresh water fish that are suitable for the aquarium. The kinds of water plants are described, as well as many curiosities that can be kept in the tanks. All these things are finely illustrated.

Cloth bound, $50 \mathrm{c}$.

\section{GUIDE TO TAXIDERMY.}

This is a practical and thorough instructor in the art of mounting birds, mammals, head, fish, etc. It is a knowledge that enables one to save many valuable specimens that would otherwise be lost to the world, or it may be developed into a lucrative business during the game season. We have an illustrated prospectus for those interested. Fully illustrated; cloth bound; 310 pages.

$\$ 1.65$ postpaid. 



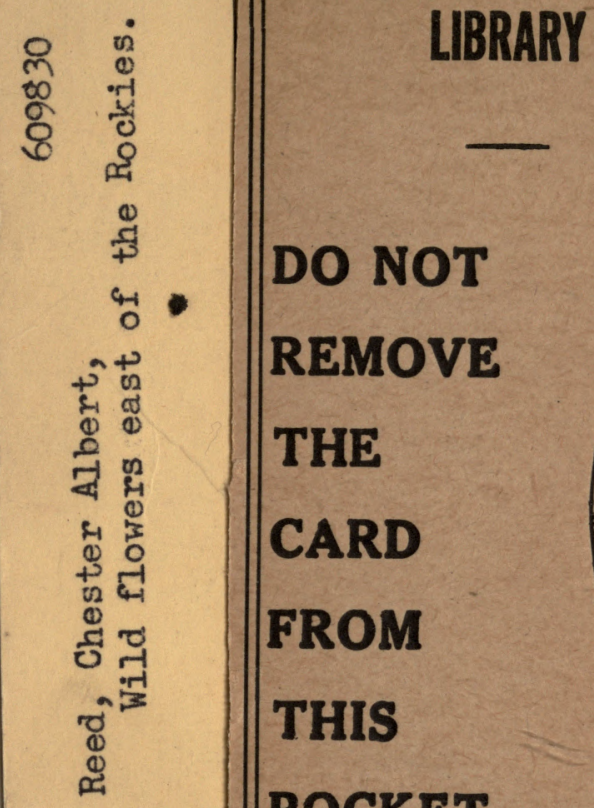

DO NOT

REMOVE

THE

CARD

FROM

THIS

POCKET

点

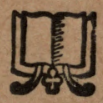


